\title{
\#USGS
}

science for a changing world

The Quality of Our Nation's Waters

Water Quality in Basin-Fill Aquifers of the Southwestern United States: Arizona, California, Colorado, Nevada, New Mexico, and Utah, 1993-2009

National Water:0uality Assessment Program

Circular 1358

U.S: Departinent of the hiterior U.S. Geologiod Sinycy 
Cover. View of basin area looking north near Layton, Utah, with Wasatch Mountains to the east. 
The Quality of Our Nation's Waters

\section{Water Quality in Basin-Fill Aquifers of the Southwestern United States: Arizona, California, Colorado, Nevada, New Mexico, and Utah, 1993-2009}

By Susan A. Thiros, Angela P. Paul, Laura M. Bexfield, and David W. Anning

National Water-Quality Assessment Program

Circular 1358 


\section{U.S. Department of the Interior SALLY JEWELL, Secretary}

\section{U.S. Geological Survey \\ Suzette M. Kimball, Acting Director}

\section{U.S. Geological Survey, Reston, Virginia: 2014}

For more information on the USGS - the Federal source for science about the Earth, its natural and living resources, natural hazards, and the environment-visit http://www.usgs.gov or call 1-888-ASK-USGS.

For an overview of USGS information products, including maps, imagery, and publications, visit $h$ ttp://www.usgs.gov/pubprod

To order this and other USGS information products, visit http://store.usgs.gov

Any use of trade, firm, or product names is for descriptive purposes only and does not imply endorsement by the U.S. Government.

Although this information product, for the most part, is in the public domain, it also may contain copyrighted materials as noted in the text. Permission to reproduce copyrighted items must be secured from the copyright owner.

Suggested citation:

Thiros, S.A., Paul, A.P., Bexfield, L.M., and Anning, D.W., 2014, The quality of our Nation's waters-Water quality in basin-fill aquifers of the southwestern United States: Arizona, California, Colorado, Nevada, New Mexico, and Utah, 1993-2009: U.S. Geological Survey Circular 1358, 113 p., http://dx.doi.org/10.3133/cir1358.

ISSN 1067-084X (print)

ISSN 2330-5703 (online)

ISBN 978-1-4113-3756-5

\section{Library of Congress Cataloging-in-Publication Data}

Thiros, Susan A.

The quality of our nation's waters---water quality in basin-fill aquifers of the southwestern United States : Arizona, California, Colorado, Nevada, New Mexico, and Utah, 1993-2009 / by Susan A. Thiros, Angela P. Paul, Laura M.

Bexfield, and David W. Anning.

pages cm. -- (Circular / U.S. Geological Survey ; 1358)

Includes bibliographical references.

ISBN 978-1-4113-3756-5

1. Water quality--Southwestern States. 2. Groundwater -- Quality -- Southwestern States . I. Paul, Angela P. II. Bexfield, Laura M. III. Anning, David W. IV. Geological Survey (U.S.) V. Title. VI. Series: U.S. Geological Survey circular ; 1358.

TD223.9.T45 2014

628.1'140979--dc23 


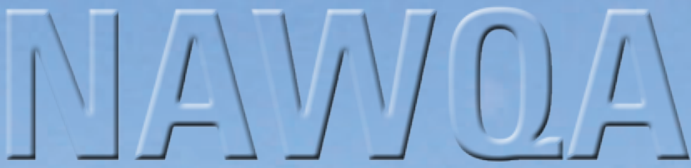

National Water-Quality Assessment Program

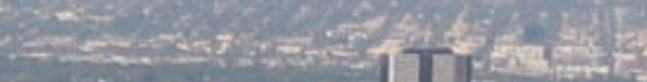

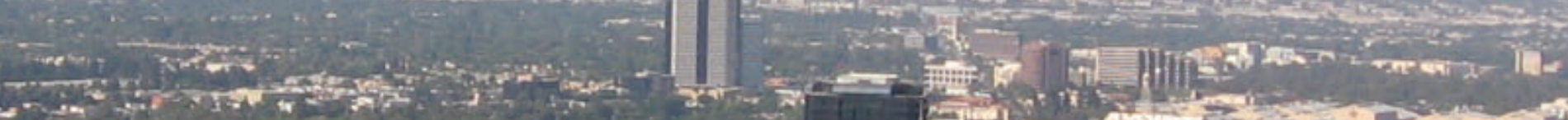

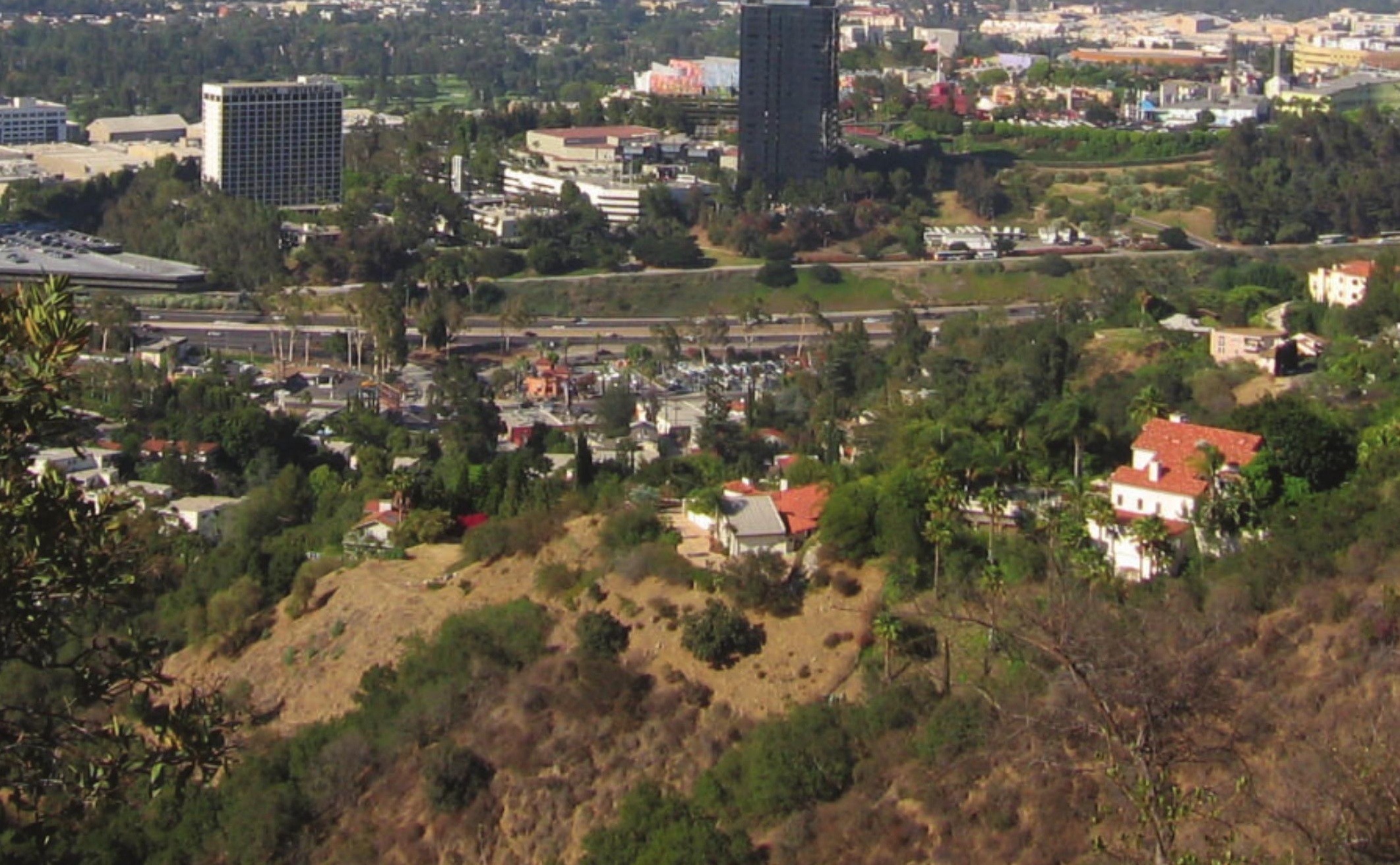




\section{Foreword}

The United States has made major investments in assessing, managing, regulating, and conserving natural resources, such as water and a variety of ecosystems. Sustaining the quality of the Nation's water resources and the health of our diverse ecosystems depends on the availability of sound water-resources data and information to develop effective, science-based policies. Effective management of water resources also brings more certainty and efficiency to important economic sectors. Taken together, these actions lead to immediate and long-term economic, social, and environmental benefits that make a difference to the lives of millions of people (http://water.usgs.gov/nawqa/applications/).

Two decades ago, Congress established the U.S. Geological Survey's National Water-Quality Assessment (NAWQA) Program to meet this need. Since then NAWQA has served as a primary source of nationally consistent information on the quality of the Nation's streams and groundwater, on ways in which water quality changes over time, and on the natural features and human activities affecting the quality of streams and groundwater. Objective and reliable data, systematic scientific studies, and models are used to characterize where, when, and why the Nation's water quality is degraded — and what can be done to improve and protect the water for human and ecosystem needs. This information is critical to our future because the Nation faces an increasingly complex and growing need for clean water to support people, economic growth, and healthy ecosystems. For example, NAWOA findings for public-supply wells, which provide water to about 105 million people, showed that 22 percent of source-water samples contained at least one contaminant at levels of potential health concern. Similarly, 23 percent of samples from domestic (or privately owned) wells, which supply untreated water to an additional 43 million people, also had contaminant levels of potential concern.

This report is one of a collection of publications that describe water-quality conditions in selected Principal Aquifers of the United States (http://water.usgs.gov/nawqa/studies/praq/). The collection is part of the series "The Quality of Our Nation's Waters," which describes major findings of the NAWQA Program on water-quality issues of regional and national concern and which provides science-based information for assessing and managing the quality of our groundwater resources. Other reports in this series focus on occurrence and distribution of nutrients, pesticides, and volatile organic compounds in streams and groundwater, the effects of contaminants and streamflow alteration on the condition of aquatic communities in streams, and the quality of untreated water from private domestic and public-supply wells. Each report builds toward a more comprehensive understanding of the quality of regional and national water resources (http://water.usgs.gov/nawqa/nawqa_sumr.htm/). All NAWQA reports are available online at http://water.usgs.gov/nawqa/bib/.

The information in this series primarily is intended for those interested or involved in resource management and protection, conservation, regulation, and policymaking at regional and national levels. In addition, the information should be of interest to those at a local level who wish to know more about the general quality of streams and groundwater in areas near where they live and how that quality compares with other areas across the Nation. We hope this publication will provide you with insights and information to meet your needs and will foster increased citizen awareness and involvement in the protection and restoration of our Nation's waters. 


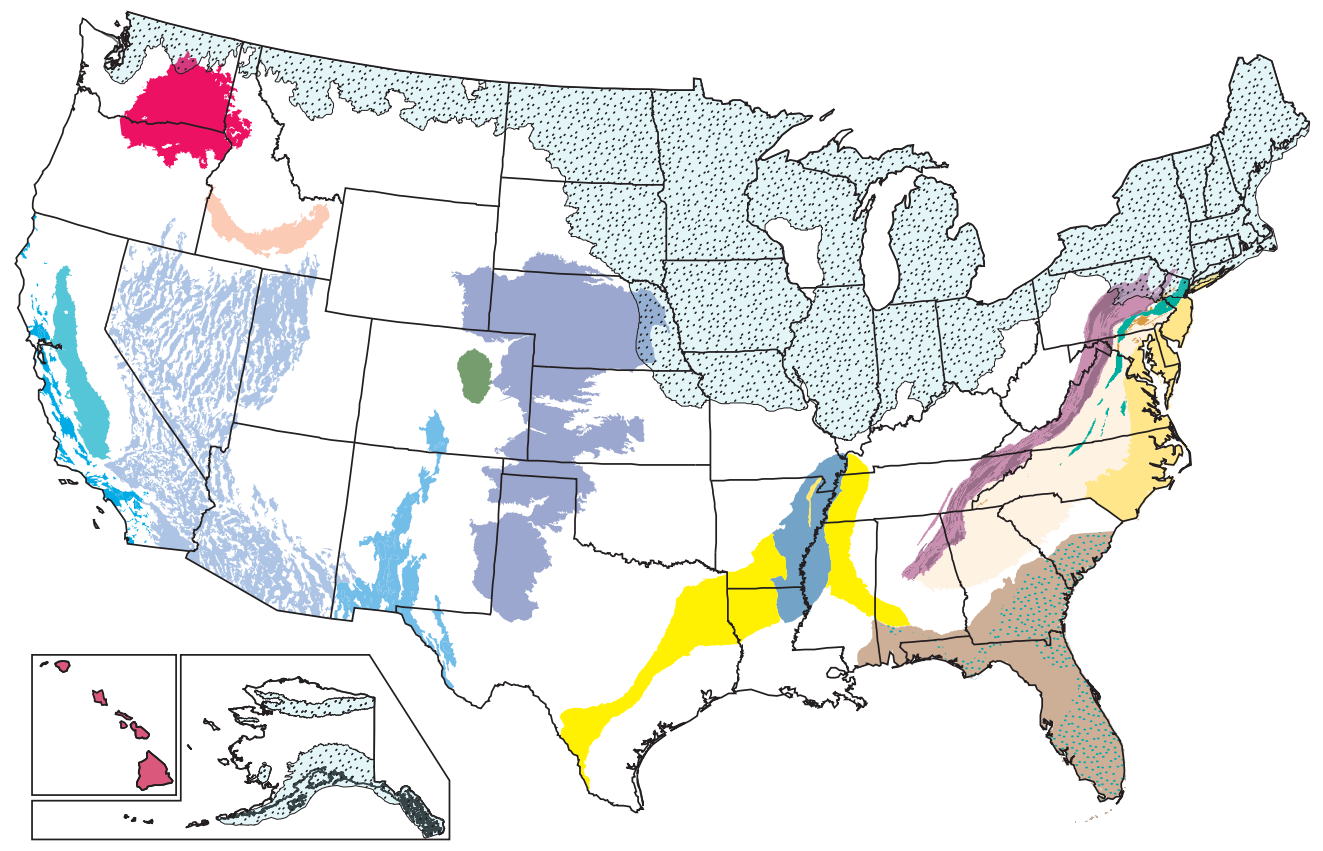

Principal Aquifers and Water-Quality Summary Reports National summary of groundwater quality in Principal Aquifers- Circular 1360

High Plains aquifer system-Circular 1337 Glacial aquifer system-Circular 1352

Northern Atlantic Coastal Plain surficial aquifer system- Circular 1353

Piedmont, Blue Ridge, and Valley and Ridge aquifers-Circular 1354

Piedmont and Blue Ridge carbonate-rock aquifers

Piedmont and Blue Ridge crystalline-rock aquifers

Valley and Ridge siliciclasticrock aquifers

Valley and Ridge carbonaterock aquifers

Early Mesozoic basin aquifers

Upper Floridan aquifer and overlying surficial aquifers-
Mississippi embayment-Texas coastal uplands aquifer system - Circular 1356

$\square$ Mississippi River Valley alluvial aquifer

Denver Basin aquifer system-Circular 1357 Southwest Principal Aquifers-Circular 1358

California Coastal Basin aquifers

Central Valley aquifer system

Basin and Range basin-fill aquifers

Rio Grande aquifer system

Western Volcanics-Circular 1359

Hawaiian volcanic-rock aquifers

Snake River Plain basin-fill and basaltic-rock aquifers

Columbia Plateau basin-fill and basaltic-rock aquifers 


\section{Contents}

Chapter 1: Overview of Major Findings and Implications ...............................................................1

Chapter 2: NAWQA Approach to Assessing Groundwater Quality................................................7

Chapter 3: Background: Environmental Setting, Hydrogeology, Population, Land Use, and

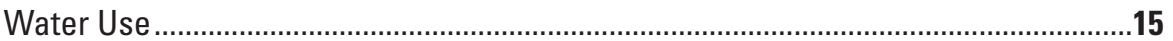

Chapter 4: The Hydrology of Southwest Basin-Fill Aquifers and How Human Alterations Affect Groundwater Quality....................................................................................25

Chapter 5: Quality of Groundwater Used for Drinking and Irrigation in Southwest

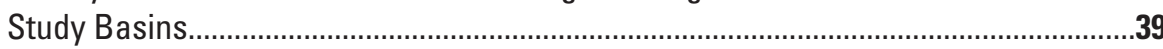

Chapter 6: Understanding Where and Why Contaminants Occur in Southwest Basin-Fill Aquifers ....................................................................................................

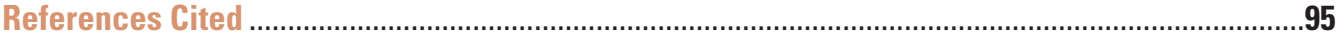

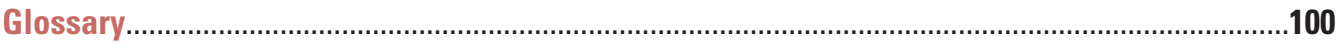

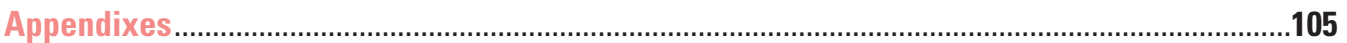




\section{Introduction to This Report}

This report presents information from a regional assessment of the water quality in the Southwest basin-fill aquifers. It is one of a series of reports by the U.S. Geological Survey (USGS) National Water-Quality Assessment (NAWQA) Program. The assessment explains where and why specific groundwaterquality conditions occur in the Southwest. Understanding the quality of water in the basin-fill aquifers and the natural and human-related factors that affect it is important because of consequences for human health and for sustained availability of groundwater for desired uses in the Southwest. This information is provided to help water managers estimate groundwater-quality conditions in unmonitored areas, assess the susceptibility and vulnerability of groundwater under different basin-development scenarios, and develop cost-effective groundwater-monitoring programs.

Water-quality conditions in the Southwest basin-fill aquifers, referred to and summarized in this report as the Southwest Principal Aquifers, are discussed in greater detail in other reports that are listed in appendix 1. Detailed technical information, data and analyses, collection and analytical methodology, models, graphs, and maps that support the findings presented in this report, in addition to reports in this series from other Principal Aquifers, can be accessed at http://water.usgs.gov/nawqa/.

Basin-fill deposits form Southwest basin-fill aquifers. 
Companion studies of these aquifers are discussed in the following reports.

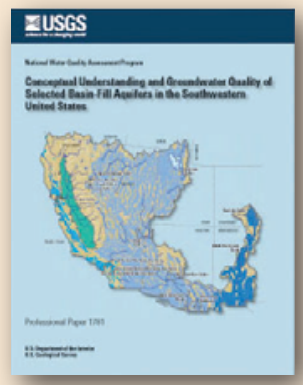

Conceptual understanding and groundwater quality of selected basin-fill aquifers in the southwestern United States

Edited by Susan A. Thiros, Laura M. Bexfield, David W. Anning, and Jena M. Huntington

U.S. Geological Survey Professional Paper 1781

(available at $h$ ttp://pubs.usgs.gov/pp/1781/)

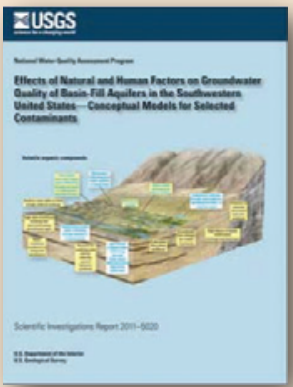

Effects of natural and human factors on groundwater quality of basin-fill aquifers in the southwestern United StatesConceptual models for selected contaminants

By Laura M. Bexfield, Susan A. Thiros, David W. Anning, Jena M. Huntington, and Tim S. McKinney

U.S. Geological Survey Scientific Investigations Report 2011-5020 (available at http://pubs.usgs.gov/sir/2011/5020/)

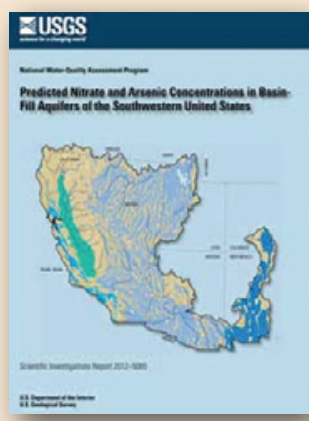

Predicted nitrate and arsenic concentrations in basin-fill aquifers of the southwestern United States

By David W. Anning, Angela P. Paul, Tim S. McKinney, Jena M. Huntington, Laura M. Bexfield, and Susan A. Thiros

U.S. Geological Survey Scientific Investigations Report 2012-5065 (available at http://pubs.usgs.gov/sir/2012/5065/) 


\section{Chapter 1: Overview of Major Findings and Implications}

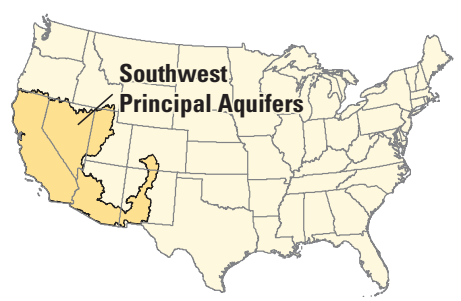

7 he Southwest Principal Aquifers are a vital groundwater resource that underlies a vast area in the southwestern United States. More than 46 million people - 15 percent of the Nation's population - reside in the arid and semiarid area that encompasses the Southwest Principal Aquifers. The California Coastal Basin aquifers, Central Valley aquifer system, Basin and Range basin-fill aquifers, and Rio Grande aquifer system, all basin-fill aquifers, are grouped together to form the Southwest Principal Aquifers. Groundwater is an important source of drinking and irrigation water in many Southwest basins. Groundwater quality and the effects of contaminant movement are of critical importance to the 1.4 million people in mostly rural areas who obtain their water from domestic wells.

The San Bernardino Mountain tower above the urbanized Santa Ana Basin in southern California. Basin-fill aquifers are an important source of drinking water for residents of this and other Southwest basins.
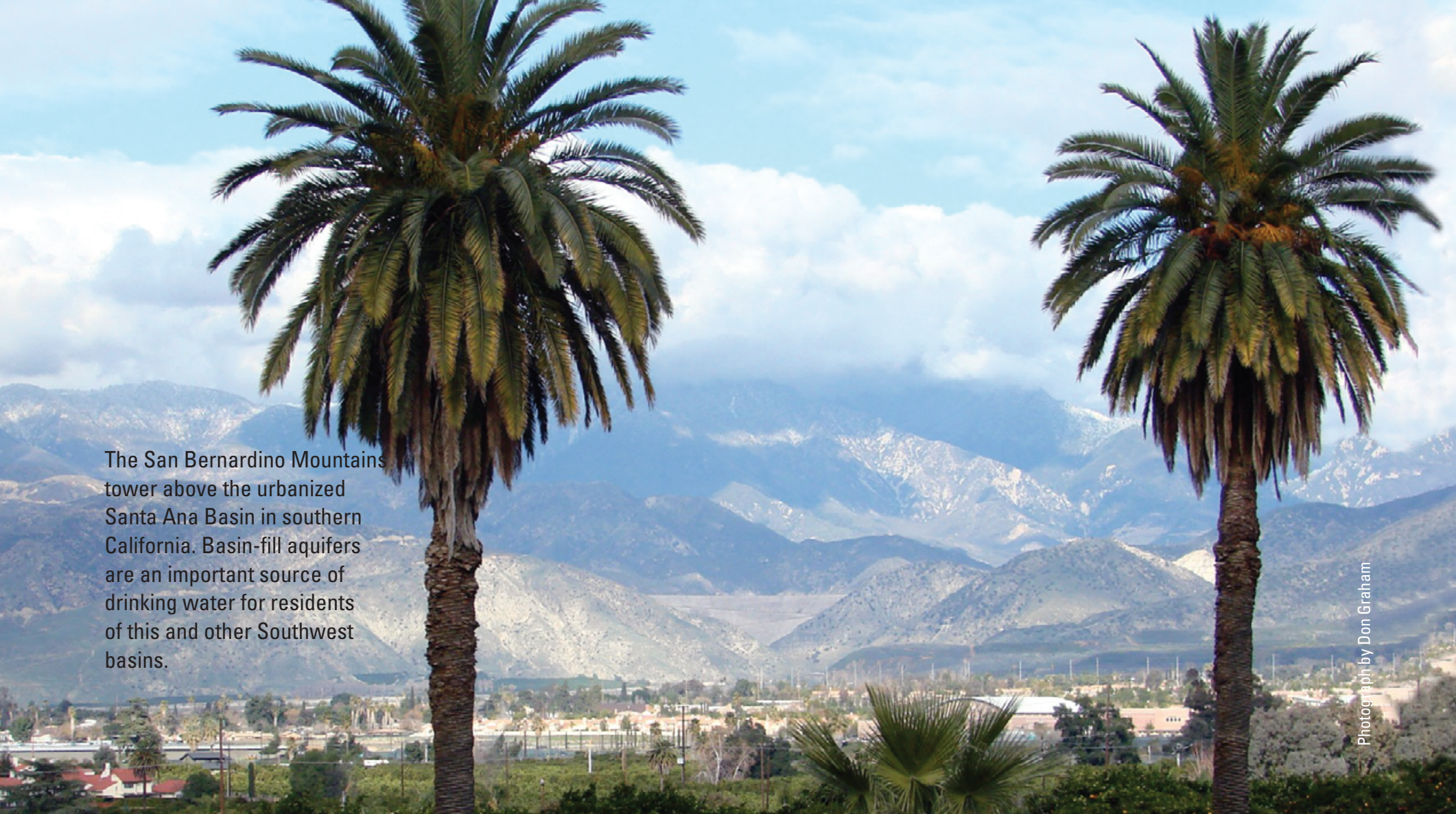


\section{Water Quality of the Southwest Basin-Fill Aquifers}

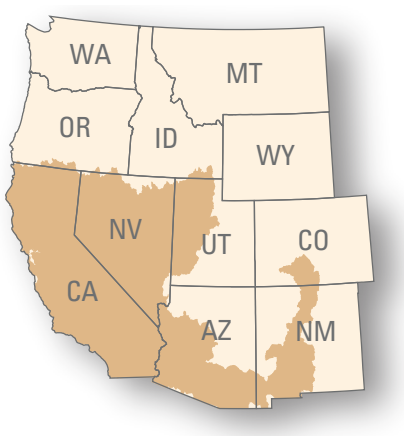

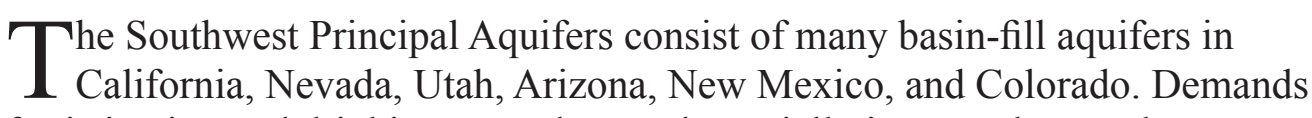
for irrigation and drinking water have substantially increased groundwater withdrawals and irrigation return flow to some of these aquifers. These changes have increased the movement of contaminants from geologic and human sources to depths used to supply drinking water in several basin-fill aquifers in the Southwest.

\section{Contaminants in water from one of every three drinking-water wells sampled are a potential human-health concern}

Water from about 42 percent of domestic wells and 26 percent of public-supply wells in the Southwest contained at least one contaminant at a concentration that was greater than its human-health benchmark. Arsenic, nitrate, and uranium exceeded their respective U.S. Environmental Protection Agency Maximum Contaminant Levels (MCLs) more than twice as frequently in Southwest drinking-water wells than in drinking-water wells nationwide.

The widespread detection of contaminants in domestic wells and the lack of
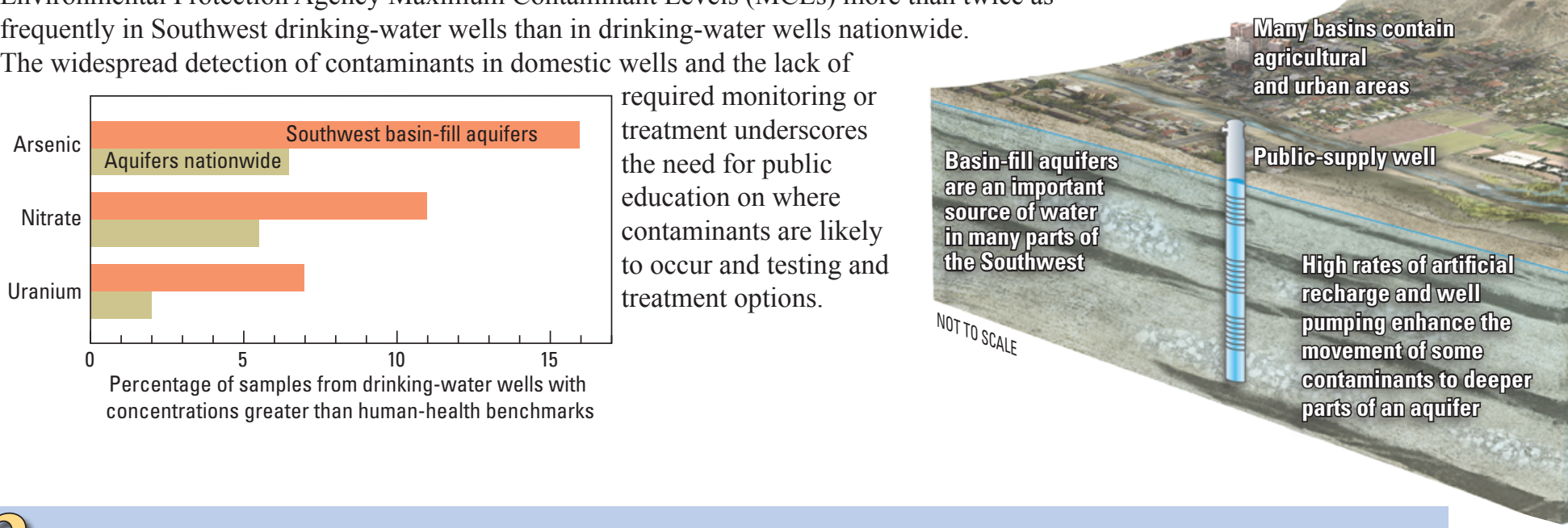

\section{Arsenic and uranium derived from geologic sources are potential drinking-water concerns}

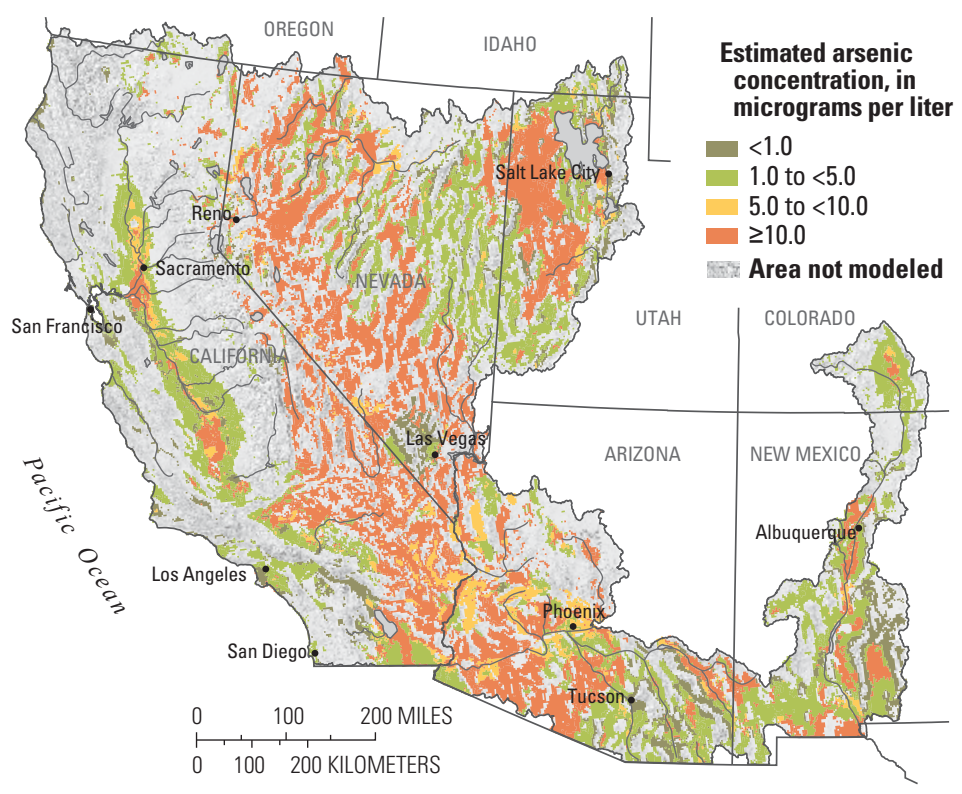

Volcanic and granitic rocks are geologic sources of arsenic and uranium in groundwater. Water sampled from 14 percent of domestic wells and 19 percent of public-supply wells in the Southwest exceeded the MCL for arsenic. Exposure to arsenic and uranium contributes to an increased risk of cancer. Overall, contaminants in basin-fill aquifers from geologic sources are a greater concern for drinking water than are contaminants from human-related sources.

A statistical model estimates that arsenic concentrations in groundwater in almost half of the basin area in the Southwest are equal to or greater than the MCL. Understanding the factors that affect concentrations of arsenic and other contaminants with geologic sources in groundwater can help water suppliers prioritize areas for new groundwater development and reduce treatment costs. 


\section{Dissolved-solids concentrations in groundwater are increasing in some areas}

Dissolved-solids concentrations in deep wells used for public supply typically are low, but substantial increases in concentrations over time in some areas of the Southwest raise questions about the long-term viability of the groundwater resource for drinking. Dissolved solids, which can impart an unpleasant taste to water, were measured at concentrations that exceeded the recommended maximum value in one of every four drinking-water wells (31 percent of domestic wells and 19 percent of public-supply wells).

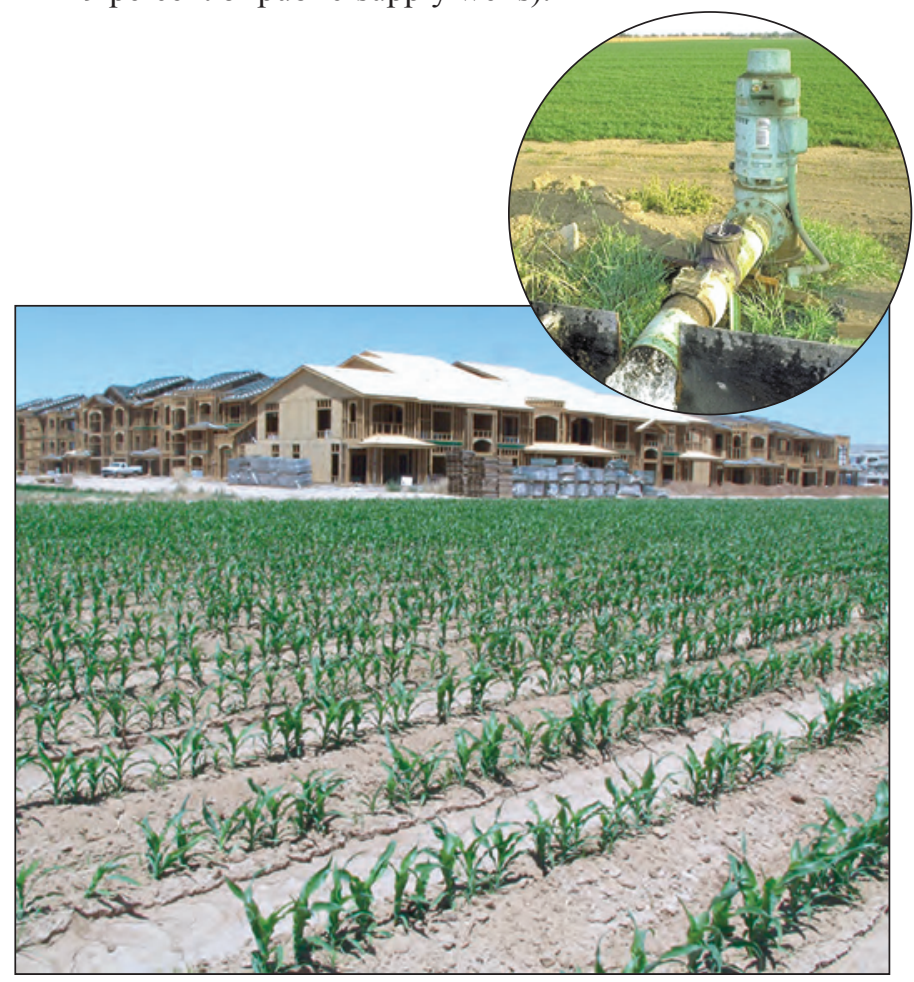

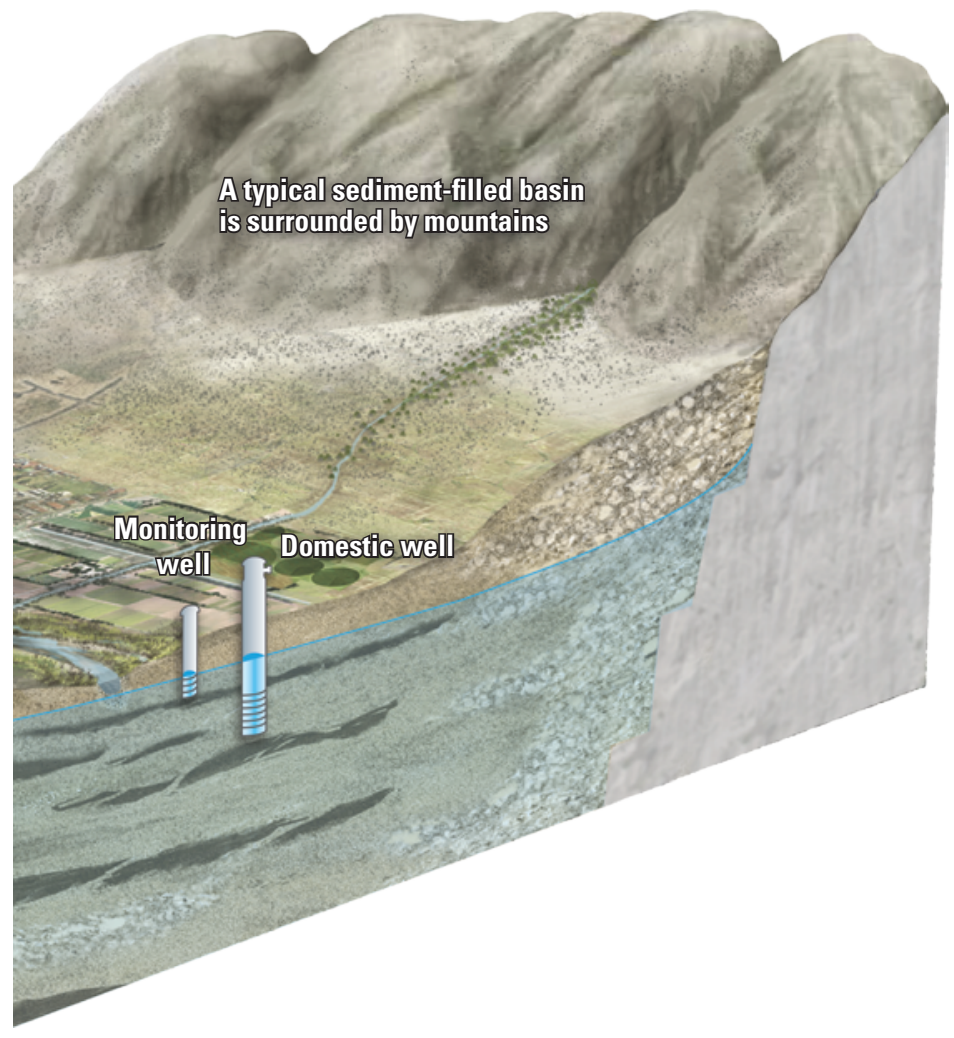

Artificial recharge and groundwater withdrawals are moving contaminants to deeper parts of basin-fill aquifers

Excess irrigation water and groundwater withdrawals for irrigation and public supply can increase the movement of contaminants from human-related sources to deeper parts of basin-fill aquifers. Contaminants include nitrate from fertilizers and manure, and volatile organic compounds and pesticides used in urban and agricultural areas. Nitrate concentrations exceeded the MCL in 18 percent of domestic wells and almost 4 percent of public-supply wells in the Southwest. Surprisingly, artificial recharge and groundwater withdrawals also are contributing to the release of naturally occurring uranium from aquifer sediments - concentrations in one of four domestic wells in the eastern Central Valley, California, exceeded the MCL.

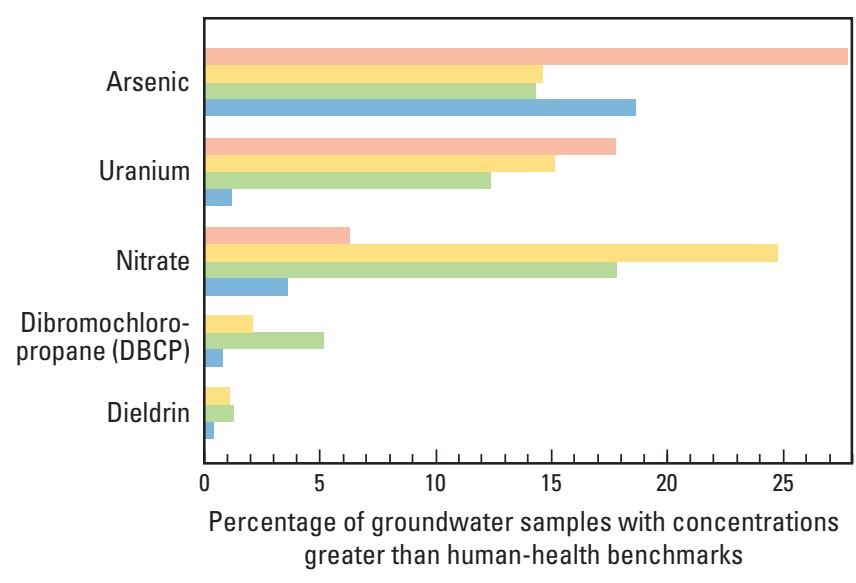

Direction of generally increasing well depth $\downarrow$

Urban monitoring wells Agricultural monitoring wells Domestic wells Public-supply wells 


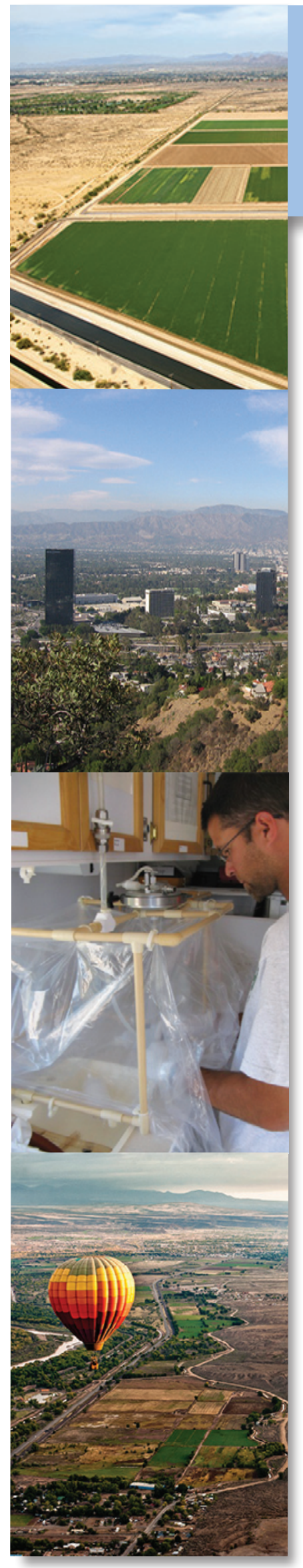

\section{Overview of Major Findings and Water-Quality Issues for the Southwest Basin-Fill \\ 1 Contaminants in water from one of every three drinking-water wells sampled are a potential human-health concern}

Water from 35 percent of drinking-water wells in the Southwest (42 percent of domestic wells and 26 percent of public-supply wells) sampled as part of NAWQA studies contained at least one contaminant at a concentration that was greater than its human-health benchmark. Arsenic, uranium, and nitrate are the contaminants in Southwest basin-fill aquifers of the most concern for human health. The U.S. Environmental Protection Agency (USEPA) Maximum Contaminant Levels (MCLs) for these three contaminants were exceeded more than twice as frequently in Southwest drinking-water wells than in drinking-water wells nationwide. For example, nitrate exceeded its MCL in 29 percent of domestic wells sampled in the Central Valley aquifer system in California compared to 4 percent nationwide.

Treatment or blending of water can reduce concentrations of some contaminants to below MCLs, but adds cost. Such treatment is required for public-supply wells, which are regulated under the Safe Drinking Water Act, but is not required for domestic wells - the source of water to about 1.4 million people in the Southwest. The widespread detection of contaminants in domestic wells and the lack of required monitoring or treatment underscores the need for public education about where contaminants are likely to occur and what testing and treatment options are available. See chapters 5 and 6.

\section{Arsenic and uranium derived from geologic sources are potential drinking-water concerns}

Volcanic and granitic rocks are geologic sources of arsenic and uranium in groundwater. Arsenic-containing rocks are widespread in the Southwest, and samples from 16 percent of drinking-water wells (14 percent of domestic wells and 19 percent of public-supply wells) contained arsenic at a concentration exceeding its MCL of 10 micrograms per liter $(\mu \mathrm{g} / \mathrm{L})$. Uranium-containing rocks are less widespread, but uranium concentration exceeded its MCL of $30 \mu \mathrm{g} / \mathrm{L}$ in 7 percent of the drinking-water wells sampled (12 percent of domestic wells, but only 1 percent of public-supply wells). Exposure to arsenic and uranium contributes to an increased risk of cancer. Mineral dissolution, geochemical interactions, high rates of evapotranspiration, and other processes that typically occur in the arid Southwest can increase concentrations of arsenic and uranium in groundwater. Overall, contaminants in basin-fill aquifers from geologic sources are a greater concern for drinking water than are contaminants from human-related sources.

A statistical model estimates that arsenic concentrations in groundwater in almost half of the basin area in the Southwest are equal to or greater than the MCL. As population growth and scarce water resources in this part of the country stimulate the search for additional sources of groundwater, water treatment or blending may be necessary to reduce arsenic concentrations to below the MCL. Understanding the factors that affect concentrations of arsenic and other contaminants with geologic sources in groundwater can help water suppliers prioritize areas for new groundwater development and reduce treatment costs. See chapters 4 and 6. 


\section{Implications Aquifers}

\section{Dissolved-solids concentrations in groundwater are increasing in some areas}

Shallow groundwater in agricultural and urban areas often has high dissolvedsolids concentrations as a result of evapotranspiration, mineral dissolution, and contributions from human-related sources, such as wastewater and urban runoff. Concentrations in deep wells used for public supply typically are low, but substantial increases in concentrations over time in some areas of the Southwest raise concerns about the long-term viability of the groundwater resource for drinking. Confining layers naturally protect deep groundwater, but wells can provide pathways that rapidly transport groundwater across confining layers and, thus, short circuit the natural groundwater flow system. Dissolved solids, which can impart an unpleasant taste to water, were measured at concentrations that exceeded the recommended maximum value of 500 milligrams per liter $(\mathrm{mg} / \mathrm{L})$ in one of every four drinking-water wells sampled (31 percent of domestic wells and 19 percent of public-supply wells). See chapters 4 and 6 .

\section{Artificial recharge and groundwater withdrawals are moving contaminants to deeper parts of basin-fill aquifers}

Excess irrigation water and groundwater withdrawals for irrigation and public supply can increase the movement of contaminants from human-related sources to deeper parts of basin-fill aquifers that are pumped for drinking water. Contaminants include nitrate from fertilizers and manure, volatile organic compounds (VOCs) and pesticides used in urban and agricultural areas, and dissolved solids from irrigation water that has become more concentrated with salts by evapotranspiration. Nitrate concentrations exceeded the MCL of $10 \mathrm{mg} / \mathrm{L}$ in 18 percent of domestic wells and almost 4 percent of public-supply wells in the Southwest. At least one VOC, pesticide, or pesticide degradate was detected in 57 percent of drinking-water wells, mostly at a low but measurable concentration. Surprisingly, artificial recharge and groundwater withdrawals also are contributing to the release of naturally occurring uranium from aquifer sediments - uranium concentrations in one of four domestic wells in the eastern Central Valley, California, exceeded the MCL.

Increased development of water resources in the Southwest likely will increase the movement of contaminants to the parts of aquifers used for drinking-water supply. Groundwater can take years or decades to travel to these depths, and samples of deep groundwater collected now likely do not reflect the full effect of past and present human activities. Water-quality samples from shallow and deeper parts of an aquifer can provide an early warning of potential future water-quality concerns. Groundwater remediation across large areas is costly, slow, and generally impractical, so management practices that prevent the mobilization of contaminants are likely to be a more effective way to maintain the quality of groundwater in the Southwest. See chapters 4 and 6.

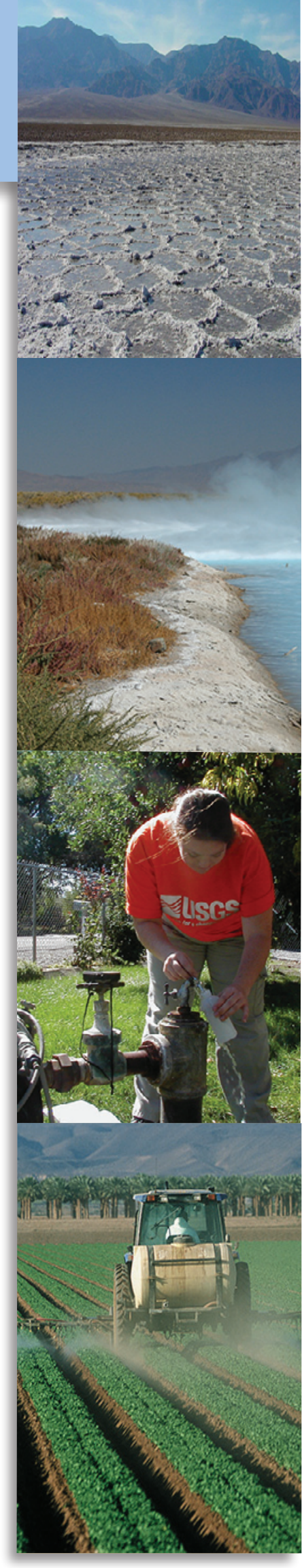





\section{Chapter 2: NAWQA Approach to Assessing Groundwater Quality}

$\mathrm{G}$ roundwater studies conducted during 1993-2009 as part of the NAWQA Program in the California Coastal Basin aquifers, the Central Valley aquifer system, the Basin and Range basin-fill aquifers, and the Rio Grande aquifer system were designed to answer broad questions about the occurrence, fate, and transport of contaminants in aquifers used as sources of drinking water. The Southwest Principal Aquifers study area contains basin-fill aquifers spread across more than 400 basins (fig. 2-1). Groundwater quality was studied in 15 basins that represent a wide range of agricultural and urban development; several basins have had some of the highest water-use rates in the Southwest for a relatively long time, while others have only recently become more developed.

\section{Understanding study results}

\section{Important aspects of the NAWQA Principal Aquifer assessments:}

- Water samples were collected at the wellhead (see diagram in sidebar, Anatomy of a well, p. 20) prior to any treatment. They represent the quality of the groundwater resource but not necessarily the quality of tap water.

- The focus of the assessments is the condition of the total resource, including groundwater in a wide range of hydrologic and land-use settings across the Nation, rather than conditions at specific sites with known waterquality concerns.

- The assessments are guided by a nationally consistent study design, and all assessments use the same methods of sampling and analysis. Findings apply to water quality of a particular aquifer but also contribute to the larger picture of how and why water quality varies regionally and nationally. This consistent approach helps to determine if a water-quality issue is isolated or widespread. (See http://water.usgs.gov/nawqa/about.htm/ for more information.)

- The assessments focus on aquifers used for water supply or on shallow groundwater that underlies an area with a particular type of land use. Because the NAWQA groundwater study areas do not cover the full spatial extent of the targeted Principal Aquifer, the findings might not represent the effects of the full range of geology, climate, and land use present.

- Analytical methods used by USGS chemists for assessments of water quality in Principal Aquifers are designed to measure constituents at as low a concentration as feasible. As a result, constituents frequently are detected at concentrations far below human-health benchmarks for drinking water (see sidebar, Human-health benchmarks and other guidelines used in this assessment, p. 43). Low-level detections allow scientists to identify and evaluate emerging issues and to track contaminant levels over time.

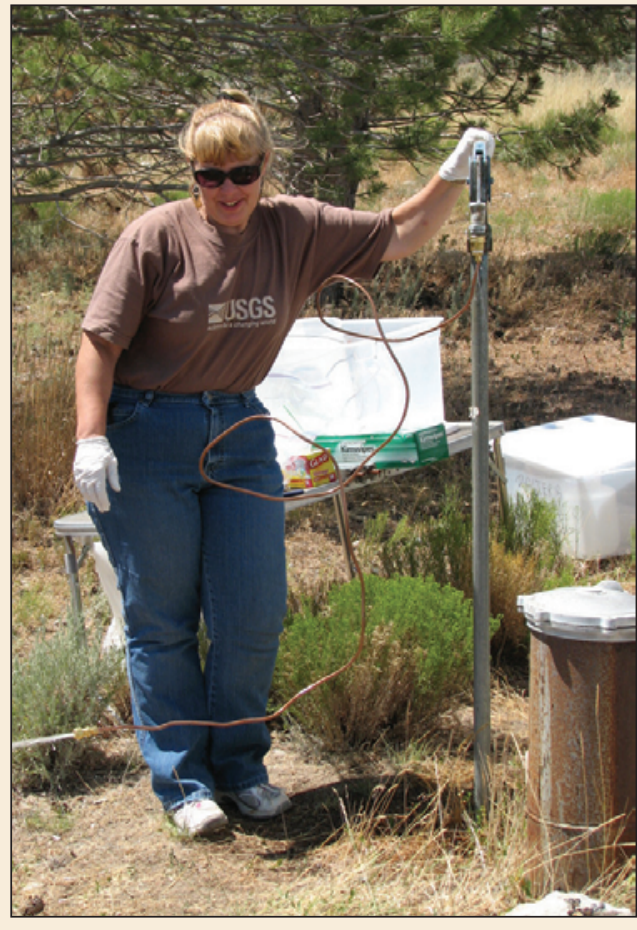

Domestic wells (an example is shown), public-supply wells, and monitoring wells in urban and agricultural areas were sampled to characterize the quality of water in Southwest basin-fill aquifers. 


\section{Principal Aquifers and study basins}

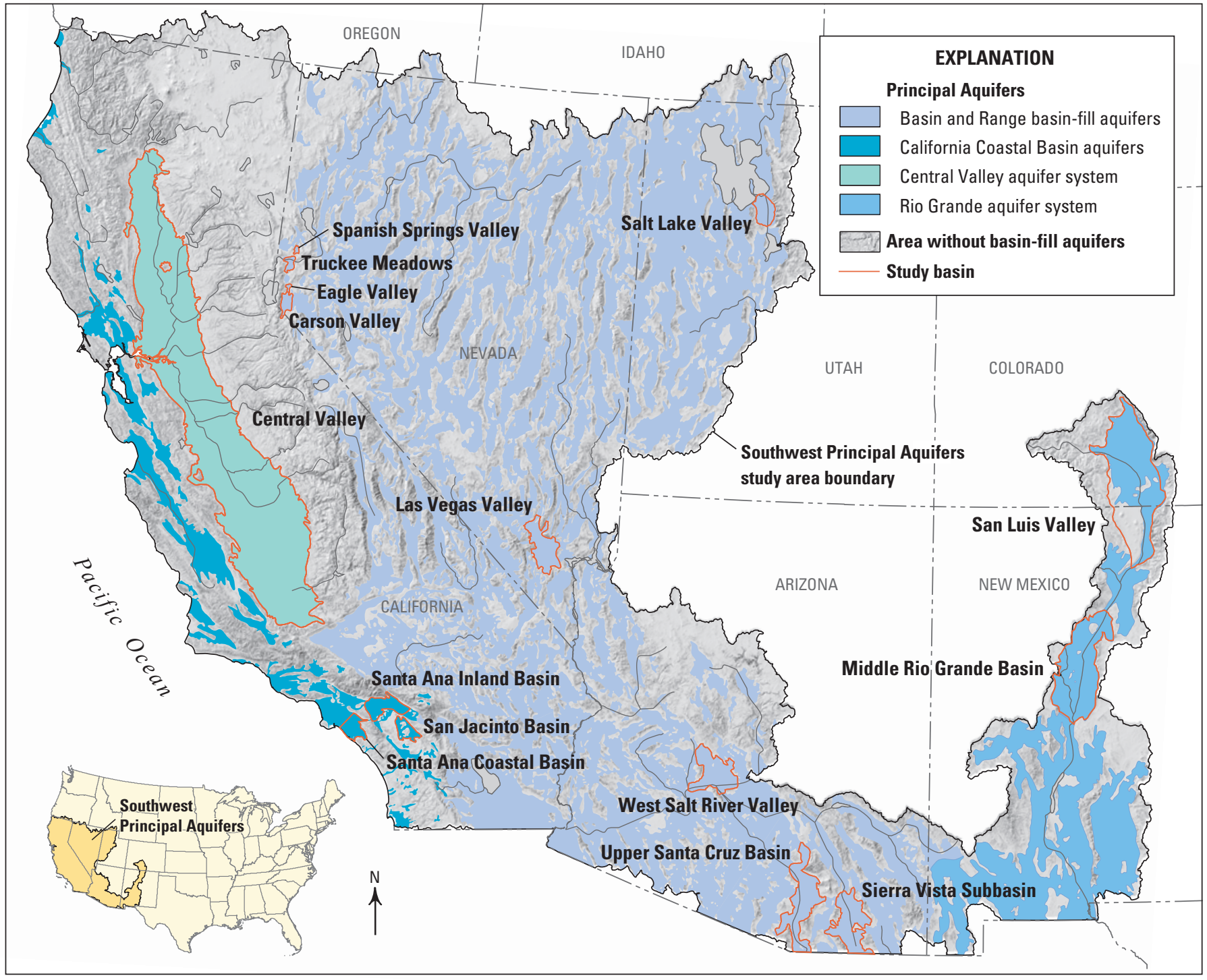

Figure 2-1. As part of the NAWQA Program, water-quality conditions were studied in 15 basin-fill aquifers that are part of four Principal Aquifers in the southwestern United States. The basins containing these aquifers were selected for study because groundwater in these areas is an important source of water for drinking and irrigation. 


\section{Assessing Water Quality in Southwest Basin- Fill Aquifers}

How does one go about characterizing the groundwater over an area as large as that covered by basin-fill aquifers in the Southwest, let alone the whole United States? The approach taken by the USGS is to use different types of groundwater studies to gain a better understanding of how and why water quality varies. These groundwater studies are the building blocks of NAWQA's water-quality assessments of Principal Aquifers. Groundwater studies were designed to answer the following questions: How does land use affect groundwater quality? How does water quality change as it moves through the aquifer? What is the quality of the drinking-water resource? Groundwater studies designed to broadly assess water-quality conditions in aquifers used for drinking-water supply were conducted to sample networks of existing pumping wells - in the NAWQA Program these studies are called major-aquifer studies (fig. 2-2). Agricultural and urban land-use studies designed to characterize and explain the quality of recently recharged groundwater (generally less than 10 years old(1)) in these land-use settings were conducted to sample mostly shallow monitoring wells that were installed as part of the NAWQA Program. Other studies focused on the groundwater quality of public water supplies and the transport of contaminants to public-supply wells. $(2,3)$

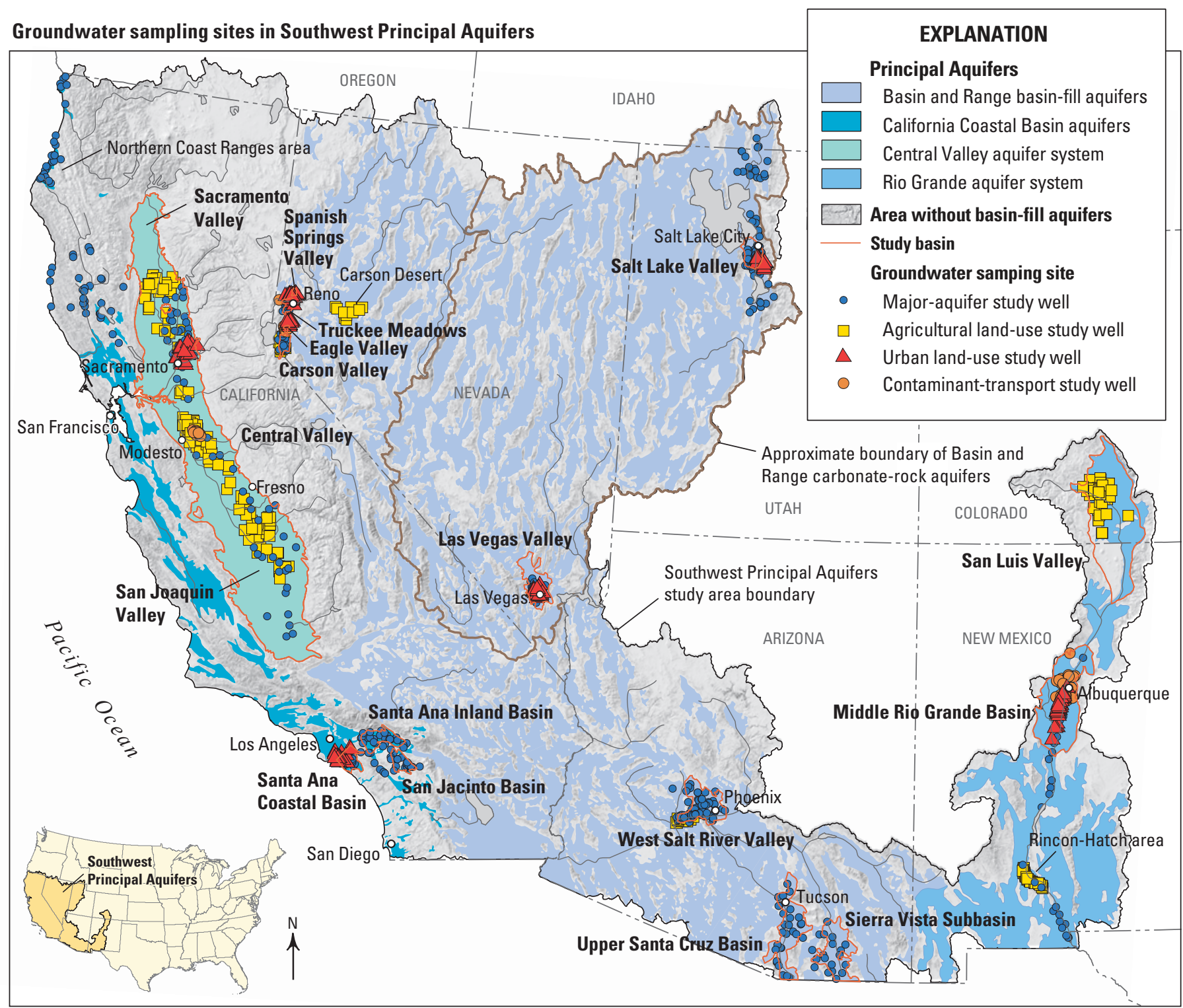

Figure 2-2. The Southwest Principal Aquifers assessment characterized the quality of water from basin-fill aquifers used as a source for drinking — water pumped from domestic and public-supply wells-by grouping samples collected mostly for major-aquifer and contaminant-transport studies. Shallow groundwater quality in agricultural and urban settings was assessed using samples collected for land-use studies. Samples also were collected from Basin and Range carbonate-rock aquifers to assess the water quality (see sidebar, Water quality of Basin and Range carbonate-rock aquifers, Nevada and Utah, p. 14). 
This Principal Aquifer assessment brings together and interprets results from all of the NAWQA groundwater studies in the Southwest Principal Aquifers study area. Throughout this assessment, the results are grouped as those that characterize the groundwater used as a drinking-water supply and those that characterize the quality of groundwater that has recently recharged in either an agricultural or an urban landuse setting. The groundwater generally used for drinking is from deeper wells and recharged the aquifers many years ago, in some cases long before any manmade chemicals were used on the land surface. The results of the land-use studies allow us to evaluate the effect of recent human activities on shallow groundwater quality and may provide an early warning for potential future contamination of drinking-water resources.

To assess water-quality conditions of the groundwater used as a drinking-water resource, one sample was analyzed from each of about 656 existing pumping wells for major and trace inorganic constituents, nutrients, VOCs, and pesticides (see appendix 2, table A2-1, and sidebar, NAWQA assessments use a wide range of geochemical data and site information, p. 13). Most of these wells were sampled as part of major-aquifer studies, with 508 wells distributed across 16 basins (or groups of basins in the case of the northern Coast Ranges area in California) (fig. 2-2; table 2-1). The other samples were collected from 69 public-supply wells in Modesto, California; Eagle and Spanish Springs Valleys, Nevada; and Albuquerque, New Mexico, as part of contaminant-transport studies that focused on the quality of public drinking water in those areas and from 79 domestic wells in the San Joaquin Valley, California, as part of agricultural land-use studies. About 48 percent of the existing pumping wells sampled were domestic wells and 39 percent were public-supply wells. The others were mostly irrigation wells, but also included stock and industrial wells.

Table 2-1. Water samples and ancillary information were collected from 1,078 wells in the Southwest Principal Aquifers study area from 1993 to 2009. Major-aquifer and contaminant-transport studies were conducted to sample wells screened at depths that represent parts of the aquifers used for drinking water, whereas the intent of land-use studies was to intercept water that recharged through a particular land use, and the wells typically were screened just below the water table. Information for the NAWQA studies, such as study location, sampling frequency, and data collected, is listed in appendix 1.

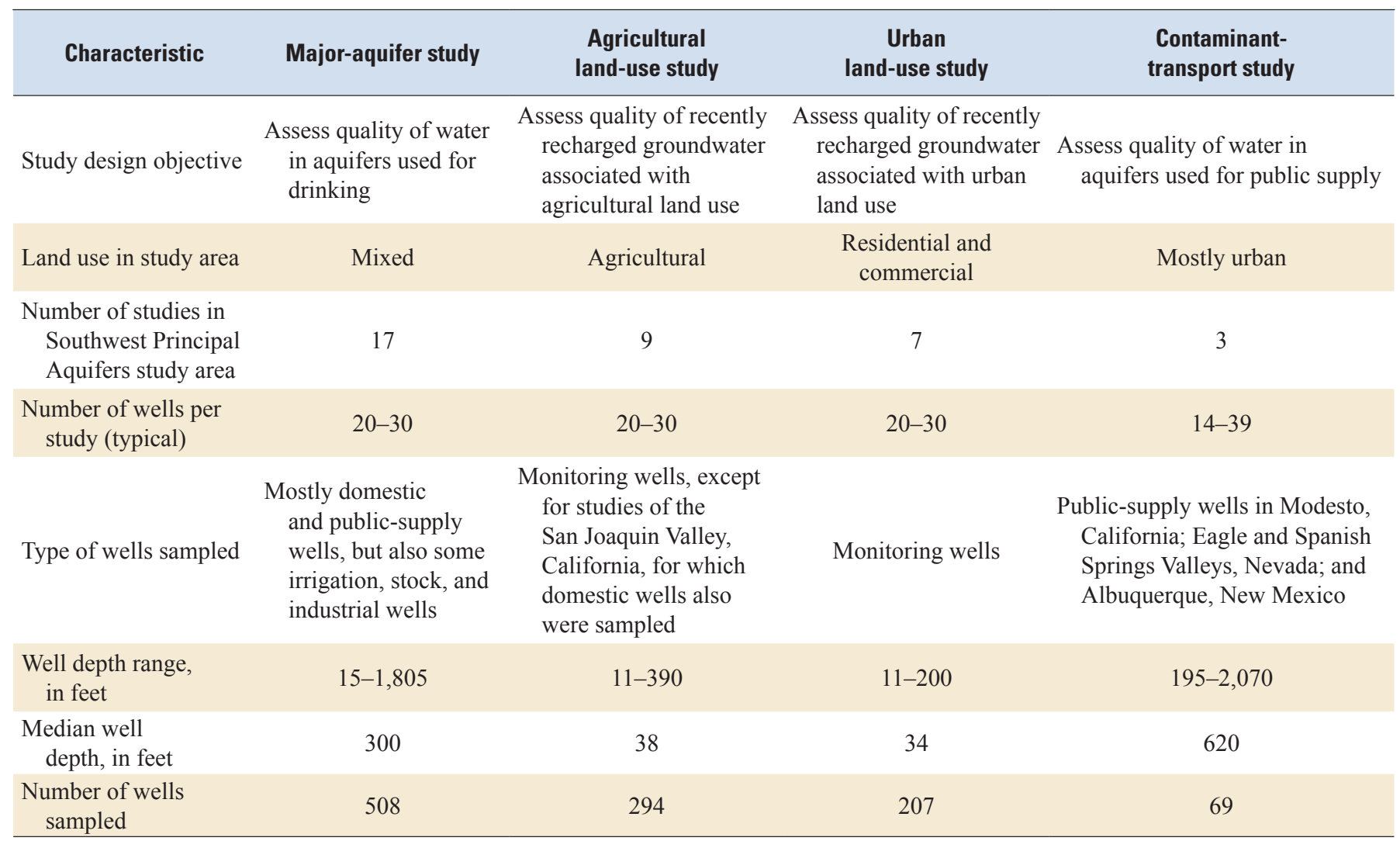


To assess the quality of recently recharged groundwater underlying urban areas, one groundwater sample was collected from each of 209 monitoring wells installed by the USGS in seven basins (fig. 2-2). The urban land-use studies focused on areas similar to those where many people work and livesingle- and multi-family residential and commercial development - in the Las Vegas (Las Vegas Valley), Carson City (Eagle Valley), Reno/Sparks (Truckee Meadows), Sacramento (Sacramento Valley in the Central Valley), Albuquerque (Middle Rio Grande Basin), Orange County (Santa Ana Coastal Basin), and Salt Lake City (Salt Lake Valley) metropolitan areas. The wells were relatively shallow-median depth of 34 feet ( $\mathrm{ft}$ ) - and tapped groundwater near the water table. The water quality of these samples is an indication of how the chemicals we use in day-to-day life - pesticides, solvents, fertilizers - might affect the quality of groundwater used for drinking in the future.

To assess the quality of recently recharged groundwater underlying agricultural areas, one groundwater sample was collected from each of 294 monitoring and domestic wells as part of nine land-use studies (fig. 2-2). Domestic wells, ranging from 55 to $390 \mathrm{ft}$ deep (median depth of $150 \mathrm{ft}$ ), were sampled in addition to monitoring wells in the San Joaquin Valley agricultural land-use studies. The monitoring wells sampled in the agricultural areas were relatively shallowmedian depth of $33 \mathrm{ft}$ - and tapped groundwater near the water table. Factors considered in determining what land uses to study include the importance of the land-use setting to groundwater use in the studied basin and the contamination potential of the targeted land use. Different crops grown in the Southwest receive different pesticides and amounts of irrigation. The agricultural land-use studies in Carson Valley, Carson Desert, and San Luis Valley targeted alfalfa and pasture areas, major crops in the Southwest that do not require heavy use of fertilizers or pesticides. Cotton, a crop that requires multiple applications of fertilizers and pesticides during the year, was the principal crop in the West Salt River Valley study area. Flood-irrigated alfalfa, peppers, onions, wheat, cotton, and pecans were studied in the Rincon-Hatch area in the Rio Grande floodplain. Rice fields that typically are flooded for 6 months at a time were the studied setting in Sacramento Valley. Almond orchards, vineyards, and a combination of corn, alfalfa, and vegetable/row crops were the settings targeted for study in the San Joaquin Valley.

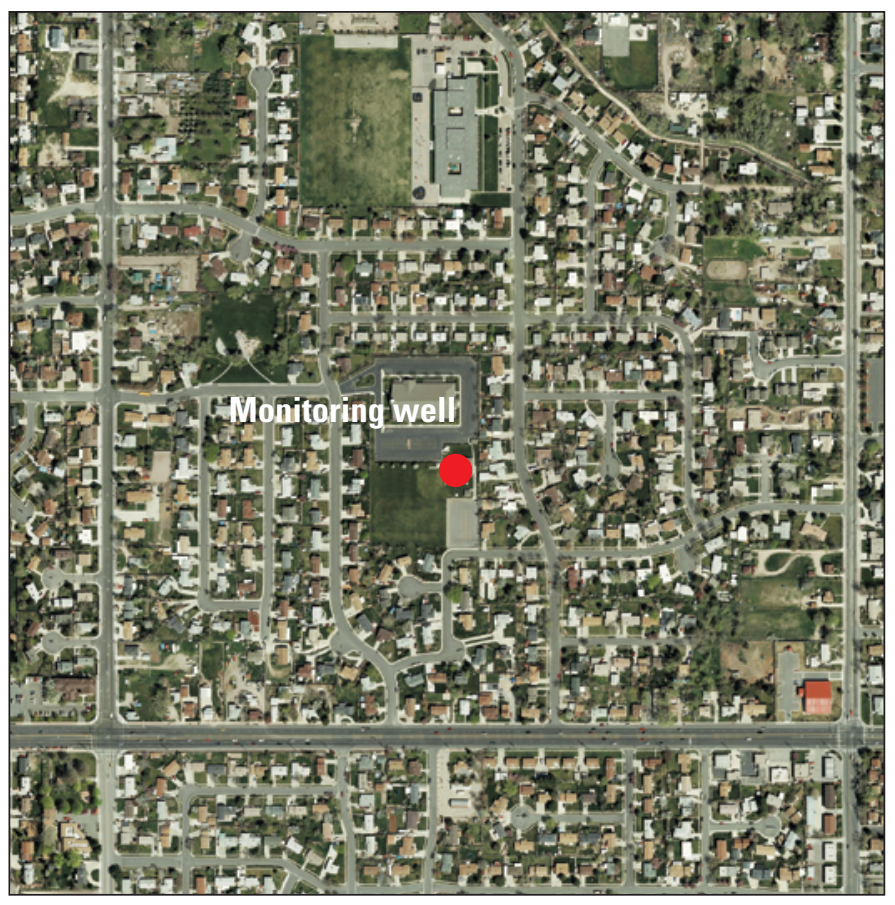

Urban land-use studies focused on the quality of shallow groundwater underlying areas of recently developed residential and commercial land (area around a monitoring well in Salt Lake Valley, Utah, is shown). Samples from monitoring wells in this setting provide information about the effects of human activities on shallow groundwater quality. 


\section{What types of wells were sampled, and how might that affect water quality?}

Two types of wells that supply drinking water were sampled: domestic (private) wells and public-supply wells. Domestic wells typically are shallower than public-supply wells and, therefore, pump water that is nearer to sources of manmade contaminants, such as fertilizers and pesticides applied at the land surface. Domestic wells commonly are located in rural areas, so they are more likely than public-supply wells to be vulnerable to contamination from agricultural chemicals. Public-supply wells pump water from deeper in the aquifer and, therefore, are more likely to have higher concentrations of constituents from geologic sources, because deeper water generally has been in contact with the aquifer materials (sediments) for a longer period of time. Public-supply wells commonly are located in suburban and urban areas, so they are more likely than domestic wells to be vulnerable to contamination from chemicals associated with urban activities. Publicsupply wells have larger pumps and longer screened intervals than domestic wells and are pumped for longer periods of time. As a result, public-supply wells pump much larger volumes of water than domestic wells and capture groundwater from a larger area; therefore, public-supply wells are more vulnerable than domestic wells to manmade contamination from distant sources. If the amount of water withdrawn is large enough, the flow direction and velocity of the groundwater can be changed, which can, in turn, affect the groundwater geochemistry and the constituents contained therein. Water from domestic wells is not regulated, and homeowners are responsible for testing, maintenance, or treatment of the water from their domestic well. Water from public-supply wells is required to be tested by the well operator on a routine basis to help assure that the water provided to consumers meets Federal and State water-quality standards.

Almost one in four of the groundwater samples collected from Southwest basin-fill aquifers were from monitoring wells. Monitoring wells are not pumped for water supply-they are used for measuring water levels or occasionally collecting water samples, but are not used for drinking water, irrigation, or to supply water for other uses. Monitoring wells sampled as part of the NAWOA groundwater studies were installed expressly for that purpose.

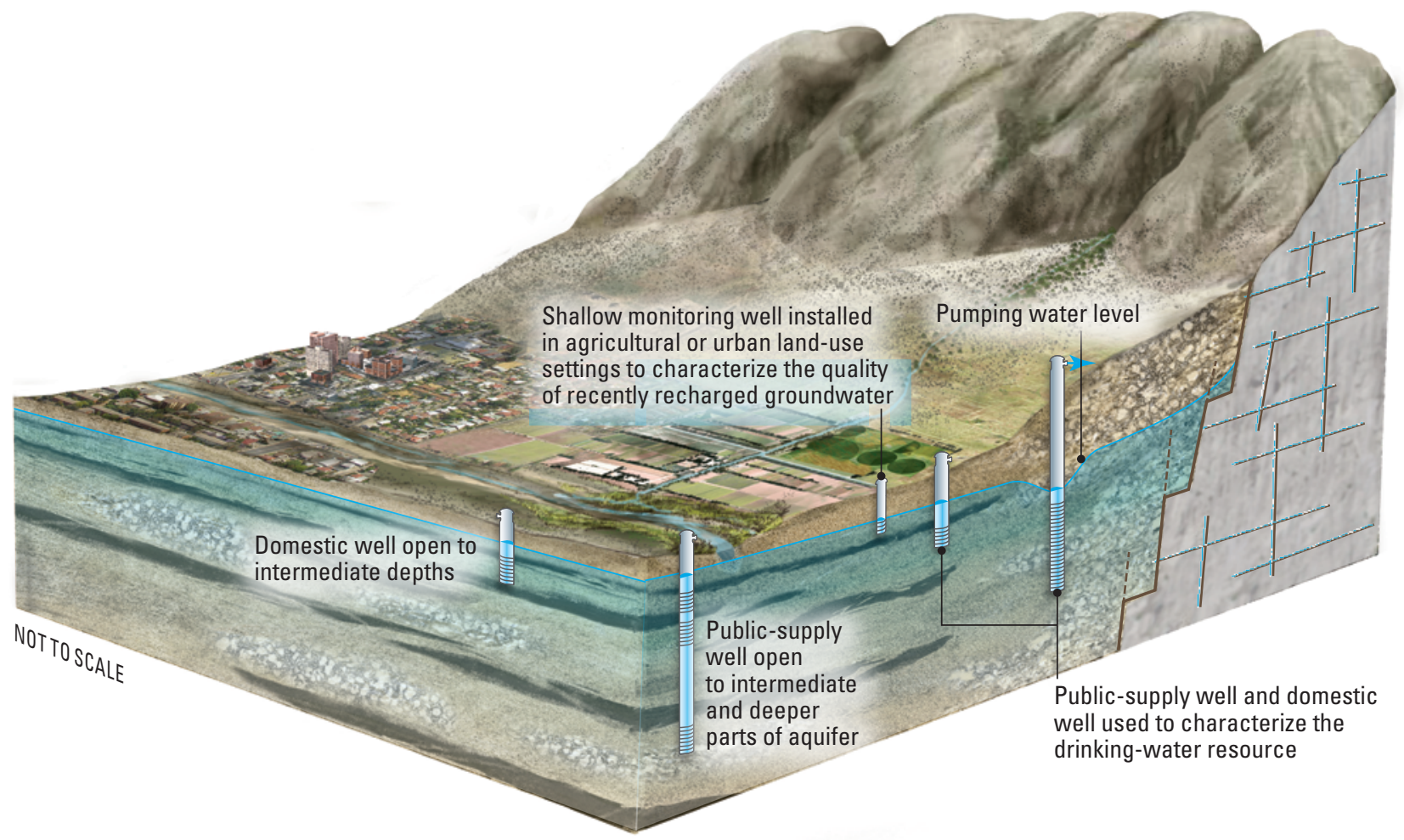

Land-use-study monitoring wells were used to sample water that has recently infiltrated to the water table. In the Southwest, the median depth of these wells below the water table is 16 feet. Domestic wells, which are used to supply drinking water to individual households, mostly were deeper-median depth below the water table of 123 feet—than the monitoring wells. Publicsupply wells are used to supply drinking water to at least 25 people(48) and typically are deeper-median depth below the water table of 364 feet-than domestic or monitoring wells. Public-supply wells commonly are open to multiple water-producing parts of the aquifer. As a result, public-supply wells commonly have open intervals that are longer and deeper and yields that are larger than those of domestic wells. 


\section{NAWQA assessments use a wide range of geochemical data and site information}

\begin{tabular}{|c|c|}
\hline \multicolumn{2}{|c|}{ Constituents measured in samples from most wells } \\
\hline Constituent group & Examples \\
\hline Water-quality properties & $\begin{array}{l}\mathrm{pH}, \text { specific conductance, dissolved } \\
\text { oxygen, temperature }\end{array}$ \\
\hline Major ions (filtered) & $\begin{array}{l}\text { Bromide, calcium, chloride, } \\
\text { magnesium, sodium, sulfate }\end{array}$ \\
\hline Trace elements (filtered) & $\begin{array}{l}\text { Arsenic, boron, iron, manganese, } \\
\text { selenium, uranium }\end{array}$ \\
\hline Nutrients (filtered) & Ammonia, nitrate, phosphorus \\
\hline Pesticides (filtered) & Herbicides, insecticides, fungicides \\
\hline Volatile organic compounds & $\begin{array}{l}\text { Solvents, gasoline hydrocarbons, } \\
\text { refrigerants, trihalomethanes, } \\
\text { fumigants }\end{array}$ \\
\hline \multicolumn{2}{|l|}{ Organic carbon (filtered) } \\
\hline \multicolumn{2}{|c|}{ Additional constituents measured in samples from some wells } \\
\hline Constituent group & Examples \\
\hline Radionuclides & Radon \\
\hline Groundwater age tracers & Tritium, chlorofluorocarbons \\
\hline Stable isotopes & Oxygen-18, hydrogen-2 \\
\hline Microorganisms & Escherichia coli and total coliforms \\
\hline \multicolumn{2}{|c|}{ Additional site information } \\
\hline $\begin{array}{l}\text { Use of well } \\
\text { Well depth } \\
\text { Depth to water } \\
\text { Well-construction data } \\
\text { Principal Aquifer }\end{array}$ & $\begin{array}{l}\text { Land-surface elevation at well } \\
\text { Land use within a } 500-\text { meter } \\
\quad(1,640 \text {-foot }) \text { radius buffer } \\
\text { Estimates of nutrient inputs } \\
\text { Estimates of pesticide use }\end{array}$ \\
\hline
\end{tabular}

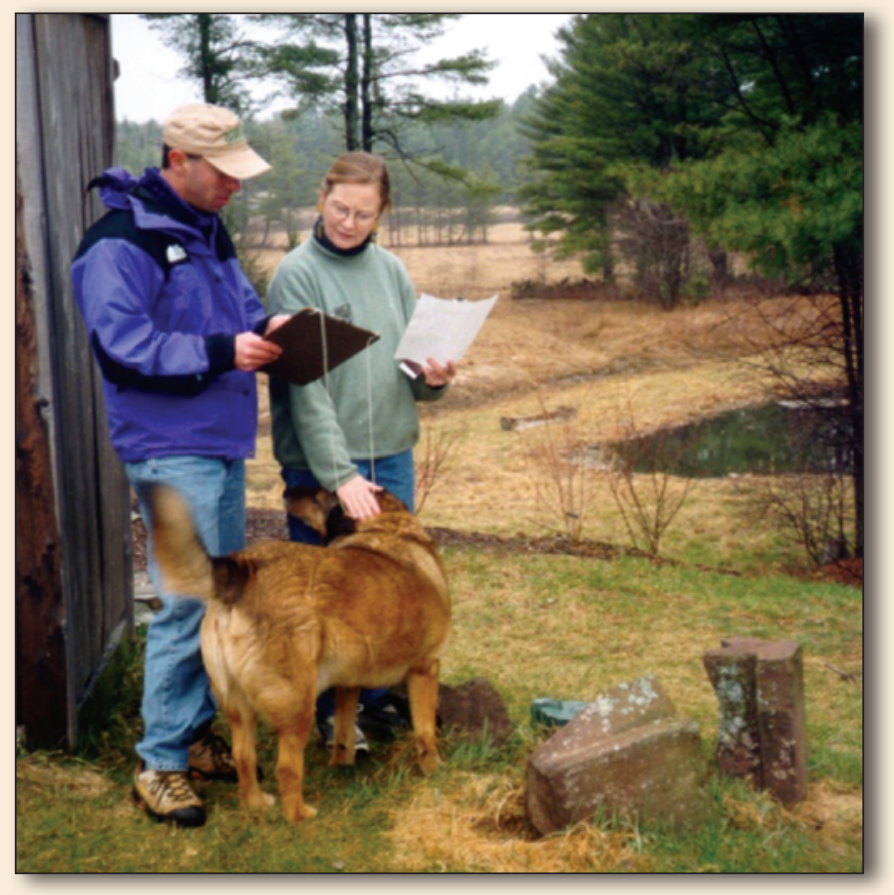

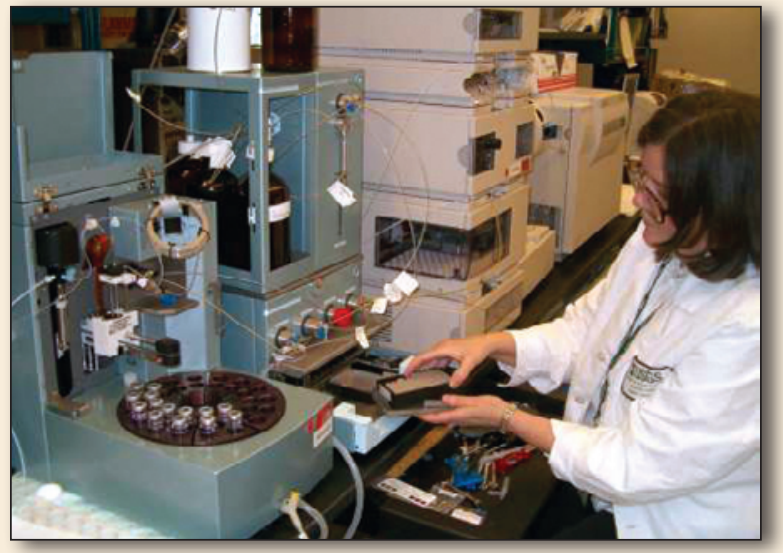

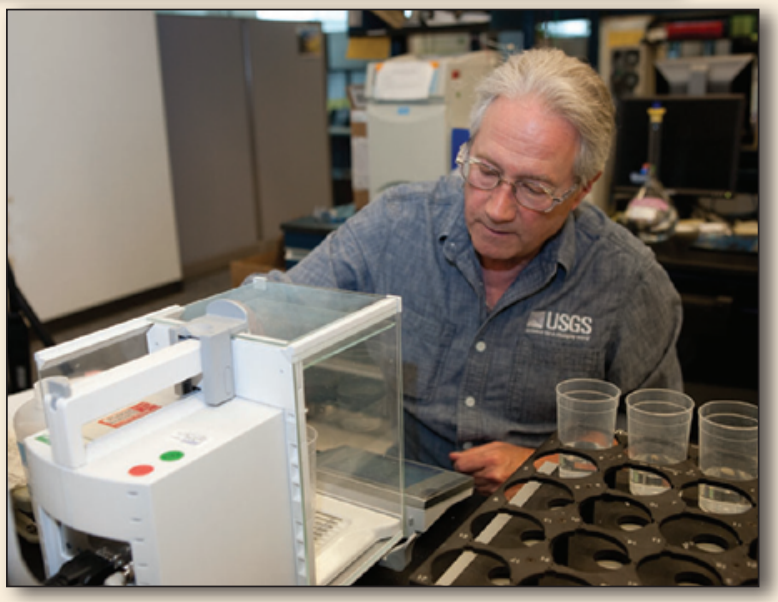

Chemists at the USGS National Water Quality Laboratory analyze groundwater samples using an array of sophisticated techniques.

Additional information (often called "ancillary information") about the well and the surrounding environment complements the chemical data measured. This additional information often is key to making sense of the chemical data. For example, the information might be used to determine that shallow groundwater is more (or less) vulnerable to contamination than deep groundwater, that domestic wells are more (or less) vulnerable to contamination than public-supply wells, or that urban land use is associated with different types of groundwater contamination than is agricultural land use. Chemical data without accompanying ancillary data are much less useful for understanding factors that affect groundwater quality. 


\section{Water quality of Basin and Range carbonate-rock aquifers, Nevada and Utah}

Most of the data on groundwater quality in the Southwest Principal Aquifers study area are from basin-fill aquifers. However, the carbonate-rock aquifers, which store a large amount of water and lie below and (or) adjacent to several Basin and Range basin-fill aquifers, are viewed as a potential future source of water for expanding cities like Las Vegas. (49) The Basin and Range carbonate-rock aquifers cover an area of about 92,000 square miles $\left(\mathrm{mi}^{2}\right)$, mostly in Nevada and Utah (see map at right). The carbonate-rock aquifers consist of thick sequences of Paleozoic limestone and dolomite interbedded with shale, sandstone, and quartzite. Depth to groundwater can be several hundreds of feet and, at present, relatively few wells tap these aquifers. A regional assessment of the availability of groundwater in both the basin-fill deposits and carbonate rocks is presented by Heilweil and Brooks. (50)

Data were collected to describe baseline water quality in the carbonate-rock aquifers and can be used to assess potential future changes in water quality. Water was sampled from 30 wells and springs tapping carbonate-rock aquifers (20 in Nevada and 10 in Utah) in 2003.(51) Major findings from the study include

- Groundwater near outcrops of a carbonate-rock aquifer can have a component of recently recharged water. As a result, human- or land-surface-related contaminants, such as pesticides, nitrate, and fecal indicator bacteria, were detected in some samples.

- The quality of water from sites located in discharge areas or wells with screens at a great depth below the land surface generally shows no effect of land-use activities. This groundwater was recharged thousands of years ago.

- Arsenic concentrations in sampled groundwater increased along regional flow paths. Long residence times and geochemical processes within the aquifer likely contribute to the elevated arsenic concentrations, although geothermal resources in the region could also be sources of arsenic.

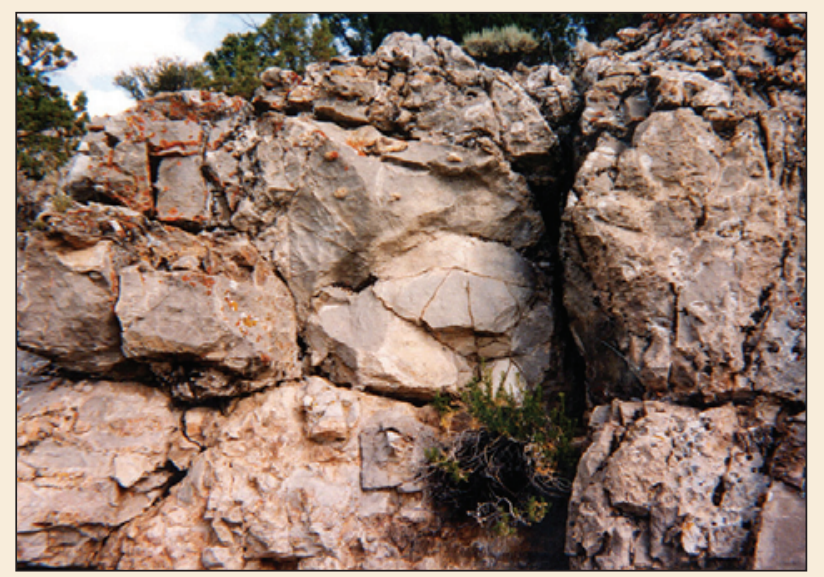

Carbonate rocks are highly fractured in some outcrops, which allows groundwater to rapidly recharge the aquifer.

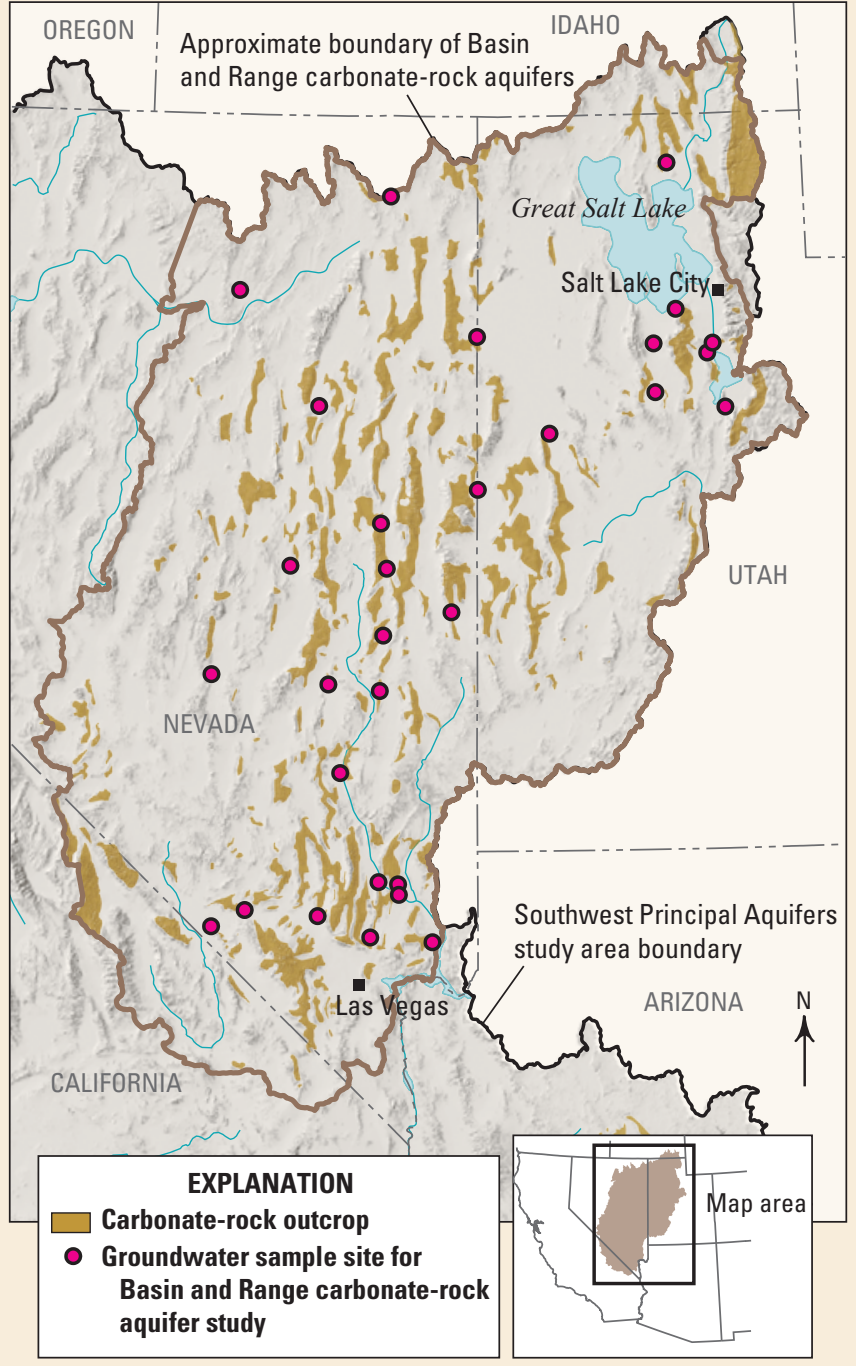

Basin and Range carbonate-rock aquifers underlie Basin and Range basin-fill aquifers in a large part of Nevada and Utah. Population growth and demand for water could lead to development of the carbonate-rock aquifers as a source of water supply. 


\section{Chapter 3: Background: Environmental Setting, Hydrogeology, Population, Land Use, and Water Use}

7 he Southwest is a land of contrasts, with its arid deserts and rocky canyons, emerald-green expanses of irrigated agriculture, and fastgrowing cities and suburbs. All these features - climate, geology, agriculture, and population growth - affect the groundwater flow system and groundwater quality. Understanding these key background features is essential for assessing the vulnerability of Southwest basin-fill aquifers to contamination.

Much of the information presented in this chapter is from the report

"Conceptual understanding and groundwater quality of selected

basin-fill aquifers in the southwestern United States" (available at

http://pubs.usgs.gov/pp/1781//).

This chapter summarizes background information for basin-fill aquifers in the Southwest and provides the context for understanding findings about water quality in this group of Principal Aquifers. The chapter covers the environmental and hydrogeologic setting and information about population, land use, and water use.

Basin-fill aquifers in the Southwest mostly are overlain by dry undeveloped land, irrigated agricultural fields, cities and towns, or a combination of these. Race Track Playa, left; Salinas Valley, center; San Fernando Valley, right; all in California. 


\section{Environmental Setting}

The Southwest Principal Aquifers study area covers about 409,000 $\mathrm{mi}^{2}$ and encompasses much of California and Nevada and parts of Utah, Arizona, New Mexico, and Colorado (fig. 2-1). The study area is characterized by sediment-filled basins or valleys that are separated by mountains composed of consolidated rock. Basin-fill aquifers, which contain permeable unconsolidated deposits, are the primary source of water for many cities and agricultural communities in this arid to semiarid area. In addition, the aquifers provide base flow to streams that support important aquatic and riparian communities.
Large variations in size, altitude, and climate in the Southwest contribute to differences in groundwater quality among basins. The generally north-south trending study basins range in size from about $23 \mathrm{mi}^{2}$ for Eagle Valley, Nevada, to about 20,000 $\mathrm{mi}^{2}$ for the Central Valley, California. Study-basin-floor altitudes range from near sea level in the California coastal basins and Central Valley to more than $8,000 \mathrm{ft}$ in the San Luis Valley, Colorado. Mountain altitudes surrounding the basins often exceed 10,000 ft and can reach more than 14,000 ft in the Sierra Nevada, California, and in the San Juan Mountains, Colorado, resulting in considerable topographic relief within a drainage basin. The wide range in

\section{Southwest Principal Aquifers at a glance}

\section{6,600,000 People living in the Southwest Principal Aquifers study area}

$1,400,000$ People in the study area who depend on domestic wells for drinking water

409,000 Extent of the study area in square miles

425

Number of unconsolidated sediment-filled basins in the Southwest

Maximum average annual precipitation, in inches, falling on most Southwest basins

$1 / 4 \quad$ Proportion of groundwater withdrawals for irrigation and public supply in the United States that is from Southwest basin-fill aquifers 
altitude causes large variations in precipitation, evaporation, temperature, and vegetation within the study area, all of which can affect water quality.

The climate of the sediment-filled basins is arid to semiarid - average precipitation in the study basins ranges from about 6 inches per year (in/yr) in Las Vegas Valley, Nevada, to almost $22 \mathrm{in} / \mathrm{yr}$ in the northern Central Valley, California. ${ }^{(4)}$ The surrounding mountains can receive much more precipitation than the basins, much of it as snow (fig. 3-1). Warm average daily temperatures in the basins combined with low humidity result in potential evapotranspiration that greatly exceeds average annual precipitation. As a consequence of evapotranspiration, salts are concentrated at and near land surface and in shallow groundwater.

Large-scale patterns of climate variability strongly, but irregularly, control weather in the Southwest, causing large year-to-year variations in precipitation and groundwater recharge. The latest drought affecting the region began in about 1999, but much longer droughts, on the scale of decades, are indicated by paleoclimate record. ${ }^{(5)}$ On a longer time scale, conditions in much of the region were cooler and wetter prior to about 10,000 years ago. Paleorecharge, that is, groundwater recharge that occurred during the last glacial period, is a major source of present-day groundwater in several of the more arid basins. ${ }^{(6)}$

\section{Average annual precipitation}

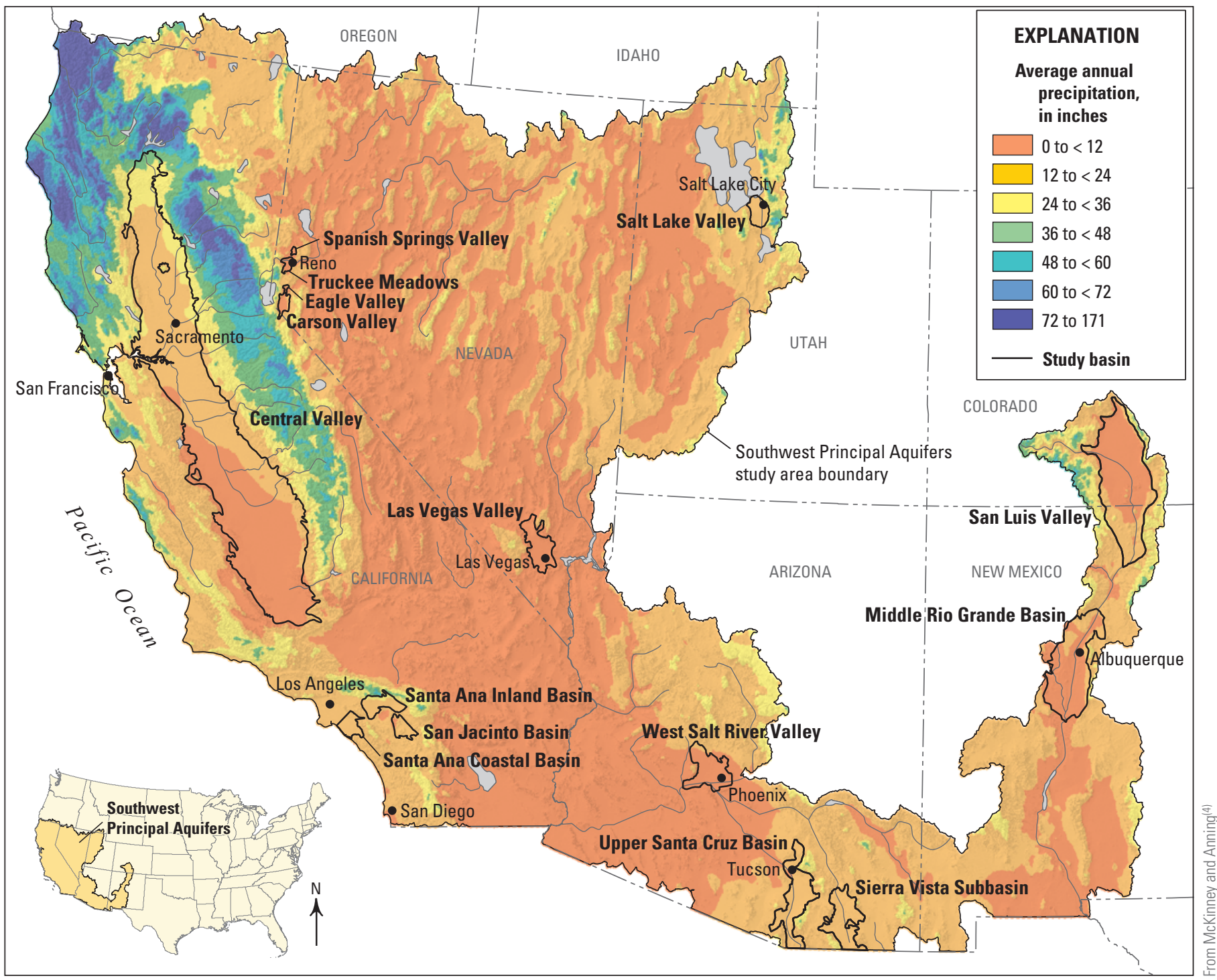

Figure 3-1. Precipitation in the Southwest is sparse-less than 12 inches per year over much of the region. Mountains receive more precipitation than basins, and snowmelt and runoff from mountainous areas contribute much of the recharge to the basin-fill aquifers. In many areas, streams flow only intermittently, and basin-fill aquifers are the major source of water for drinking and irrigation. 


\section{Hydrogeologic Setting}

Southwest basin-fill aquifers are similar hydrogeologically because they all are composed of unconsolidated to semiconsolidated gravel, sand, silt, and clay that are saturated with water. An important factor that affects the quality of groundwater in Southwest basin-fill aquifers is the type of rock that the water flows over or through (fig. 3-2). The consolidated rocks in mountainous areas are the primary source of the sediment deposited in the basins. Some rocks weather (erode) more easily than others and, therefore, contribute more dissolved constituents to groundwater. Intrusive igneous rocks and metamorphic rocks generally are less easily eroded and less soluble in groundwater than volcanic and marine-deposited sedimentary rocks. The concentration of constituents with geologic sources, such as arsenic and

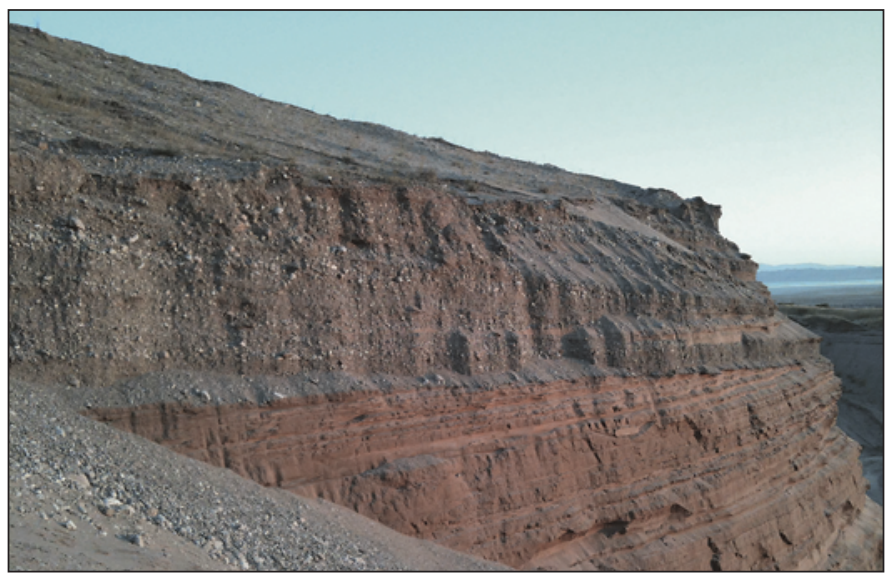

Unconsolidated basin-fill deposits exposed in a gravel pit range from fine sand and silt to gravel and cobbles.

\section{Consolidated rock types and unconsolidated deposits}

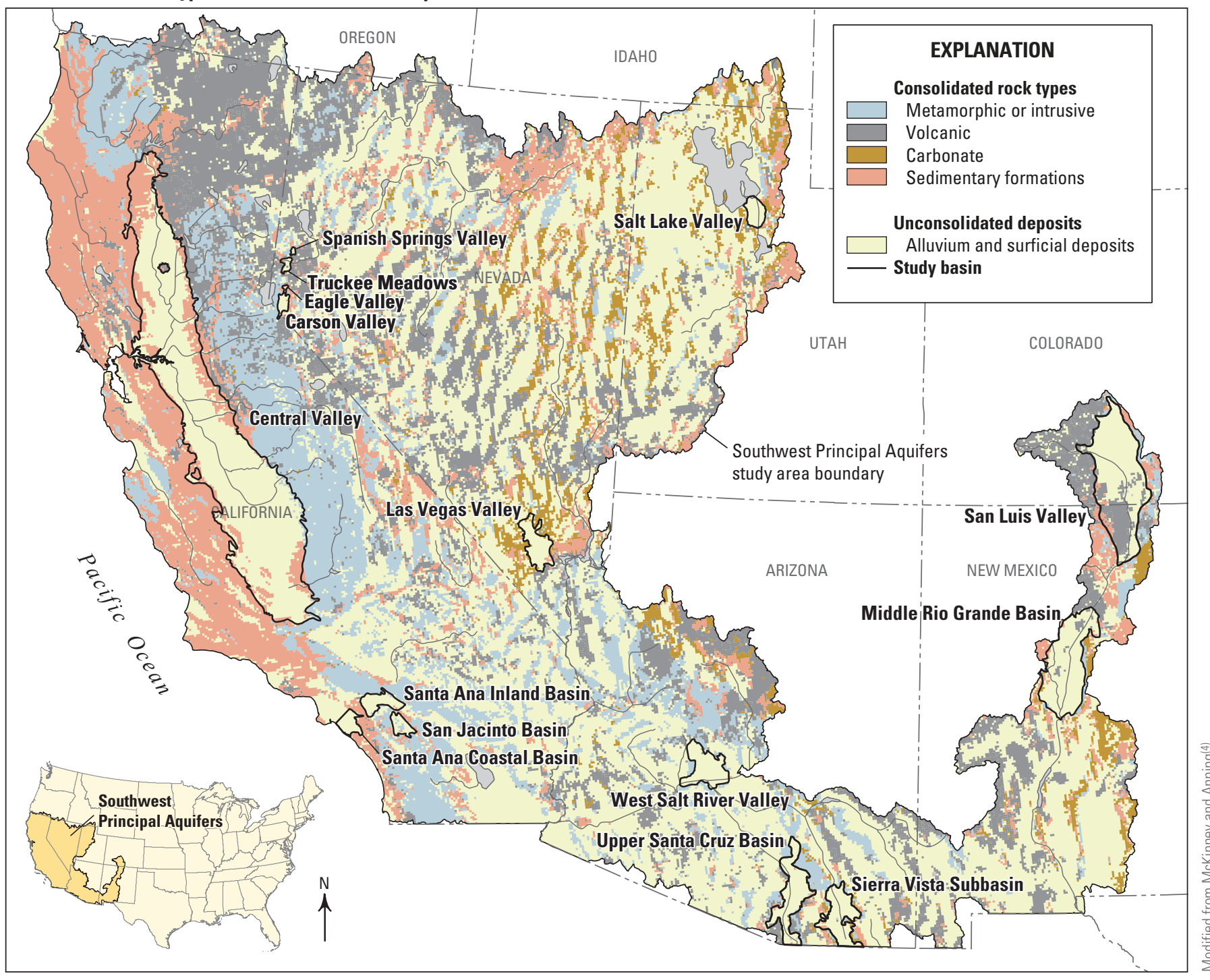

Figure 3-2. The Southwest Principal Aquifers study area contains more than $\mathbf{4 0 0}$ basins that are filled with unconsolidated deposits derived from the adjacent mountains. Differences among the rock types that are the source of the deposits contribute to differences in groundwater quality in the basins. 
uranium, in groundwater depends on the type of rock through which the groundwater flows.

Other geologic features also can affect the quality of groundwater in the basin fill. For example, faults facilitate localized upward movement of geothermal and (or) highly mineralized groundwater from greater depths to shallower parts of aquifers in some basins. This mineralized groundwater frequently has elevated concentrations of contaminants with geologic sources, such as dissolved solids and arsenic, that impair water quality.

Geologic characteristics of a basin control the recharge and movement of groundwater (fig. 3-3). The basins are bounded by faults and mountains, and most contain thick (thousands of feet) sequences of sediment. The sediments are more compact with depth, resulting in fewer connected pore spaces for groundwater to flow through and lower permeability in deeper parts of the aquifer. As a result, water flows more slowly through the aquifer at depth and, therefore, has more time to interact with the aquifer sediments. Coarsegrained sediment has been deposited by high-energy streams in alluvial fans and stream channels along the mountain fronts, where the water table (top of unconfined aquifer) can be several hundred feet below land surface. The alluvial fans transition to a flat valley floor where deposition in ancient lakes and floodplains created layers of fine-grained, less permeable sediment interbedded with more permeable layers of sand and gravel. These confining layers of silt and clay result in confined conditions in the aquifer or a confined aquifer (see sidebar, Aquifer, p. 20).

Confining layers in many basins typically occur within about $100 \mathrm{ft}$ of the land surface, although they commonly are thin and not widespread. A shallow aquifer can form above the uppermost confining layer. The quality of shallow groundwater commonly is affected by human activities at the land surface and by natural processes, such as evaporative concentration. Confining layers and upward movement of groundwater prevent the infiltration of water that could contain contaminants from the land surface, thus partially protecting the water quality of deeper parts of basin-fill aquifers. This deeper groundwater is the groundwater resource most used - water-supply wells in basin-fill aquifers of the Southwest typically pump water from between about 200 to $1,000 \mathrm{ft}$ below land surface. Publicsupply wells and irrigation wells typically are open to a greater thickness of aquifer than domestic wells because of the need for larger yields (see sidebar, What types of wells were sampled, and how might that affect water quality?, p. 12).

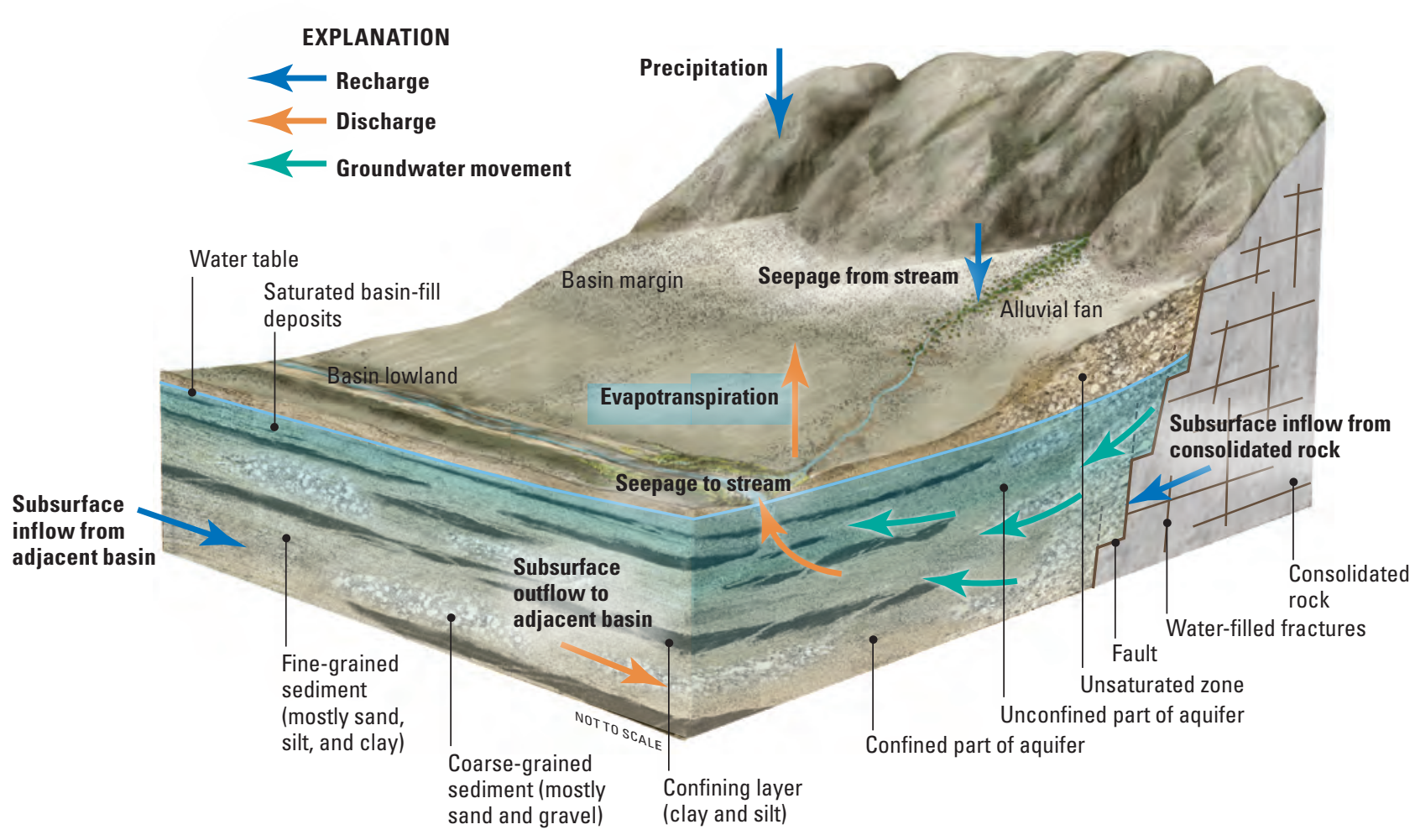

Figure 3-3. In an undeveloped Southwest basin, the principal source of recharge to the basin-fill aquifer is precipitation that falls on the surrounding mountains and drains into the basin. Groundwater moves from the basin margin to the basin lowland. Natural discharge typically occurs as evapotranspiration, flow to streams and springs, and subsurface outflow to an adjacent basin. In a developed basin, in contrast, irrigation and groundwater pumping are the primary sources of recharge and discharge (see chapter 4 for more discussion). 


\title{
Aquifer (aq.ui.fer)—ăk'wə-fər
}

\author{
An underground layer of saturated permeable materials (rock, gravel, sand, or silt) that will yield a \\ useful quantity of water to a well.
}

The unsaturated zone is the area below the land surface and above an aquifer. In addition to soil, rocks, and air, the unsaturated zone contains water from the land surface (such as rain) that is slowly moving downward to the water table of the aquifer.

An unconfined aquifer is bounded at its top by the water table, below which water fills all the pore spaces in the rock. Water from the land surface can move down into an unconfined aquifer.

A confining layer is a layer of material (often clay) through which water does not easily flow, creating a boundary between aquifers.

A confined aquifer is bounded at its top by a confining layer. Water enters or "recharges" confined aquifers where the confining layer is not present. Where the confining layer is not continuous or is breached (for example, by a well), flow between the unconfined and confined aquifer can occur.

The pressure within a confined aquifer can be greater than that in the overlying unconfined aquifer

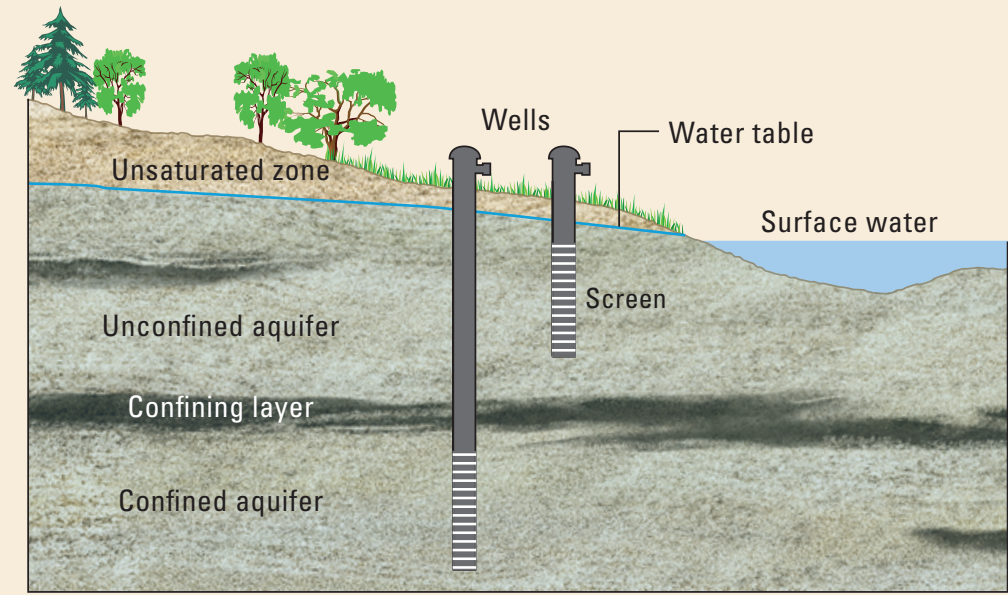

\section{Sedimentary aquifer}

Groundwater storage and flow between grains of sediment if the source of the water in the confined aquifer is at a higher elevation than the unconfined aquifer. In that case, water in a well in a confined aquifer will rise to a higher level than that in the overlying unconfined aquifer.

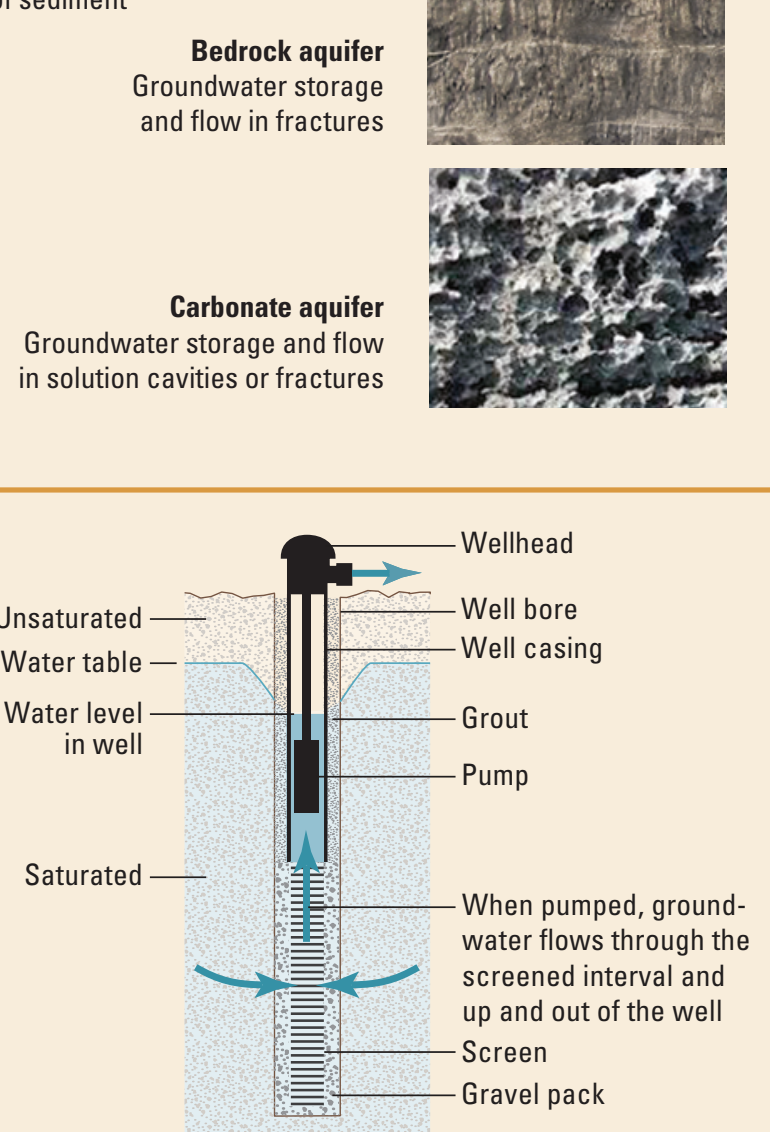

\section{Anatomy of a well}

A well is simply a hole in the ground (well bore or borehole) from which water can be removed. The well bore is lined with a well casing, such as a pipe, to prevent the well bore from collapsing. The casing, along with a sealant (called grout), also prevents water from flowing into the well from the land surface or from parts of the aquifer where the water quality may be less desirable. The casing can be open at the bottom or perforated at a specific depth with a screen, to allow water to flow into the well where it can be pumped to the surface. Coarse sand or gravel (called sand pack or gravel pack) can be placed around the well screen to help improve the flow of water into the well. Some wells are cased only near the land surface, allowing water to flow into the well from nearly the entire length of the well bore.

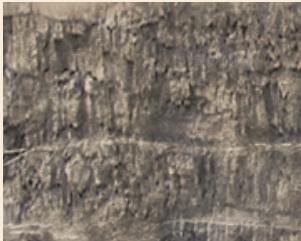




\section{Population, Land Use, and Water Use}

About 46.6 million people live in the Southwest Principal Aquifers study area, ${ }^{(7)}$ mostly in urban metropolitan areas, but also in rural agricultural communities that are associated with about 22,500 $\mathrm{mi}^{2}$ (14.4 million acres) of cropland. California is the most populous state in the Nation, with more than 37 million people (2010 census) and a population density of 239 people per square mile (13th highest nationally). Population in the Southwest is growing rapidly, putting increased pressure on much of the area's limited water resources. During 1990-2010, the population growth rate in Nevada, Arizona, and Utah was the largest in the United States. By 2030, the population in the Southwest is projected to increase by about 15 million from that of 2010.(8) An example of explosive population growth is Spanish Springs Valley, Nevada, where the population increased from less than 800 people in 1979 to about 45,000 in 2008.(9) Another example of increasing population is the Santa Ana Coastal Basin in southern California, where what was once agricultural land has been almost completely urbanized with a population density of about 7,000 people per square mile in 2005 and less than 5 percent undeveloped land. Groundwater is used for drinking by almost 2.6 million people in the Santa Ana Coastal Basin, and water quality is a major management concern.

Prior to people moving to the Southwest, the land was primarily rangeland, and rangeland still covers most of the alluvial basins (fig. 3-4). People live and grow crops where water is available, either from streams or aquifers. Most crops are cultivated on the relatively flat basin floors and, in

\section{Land use}

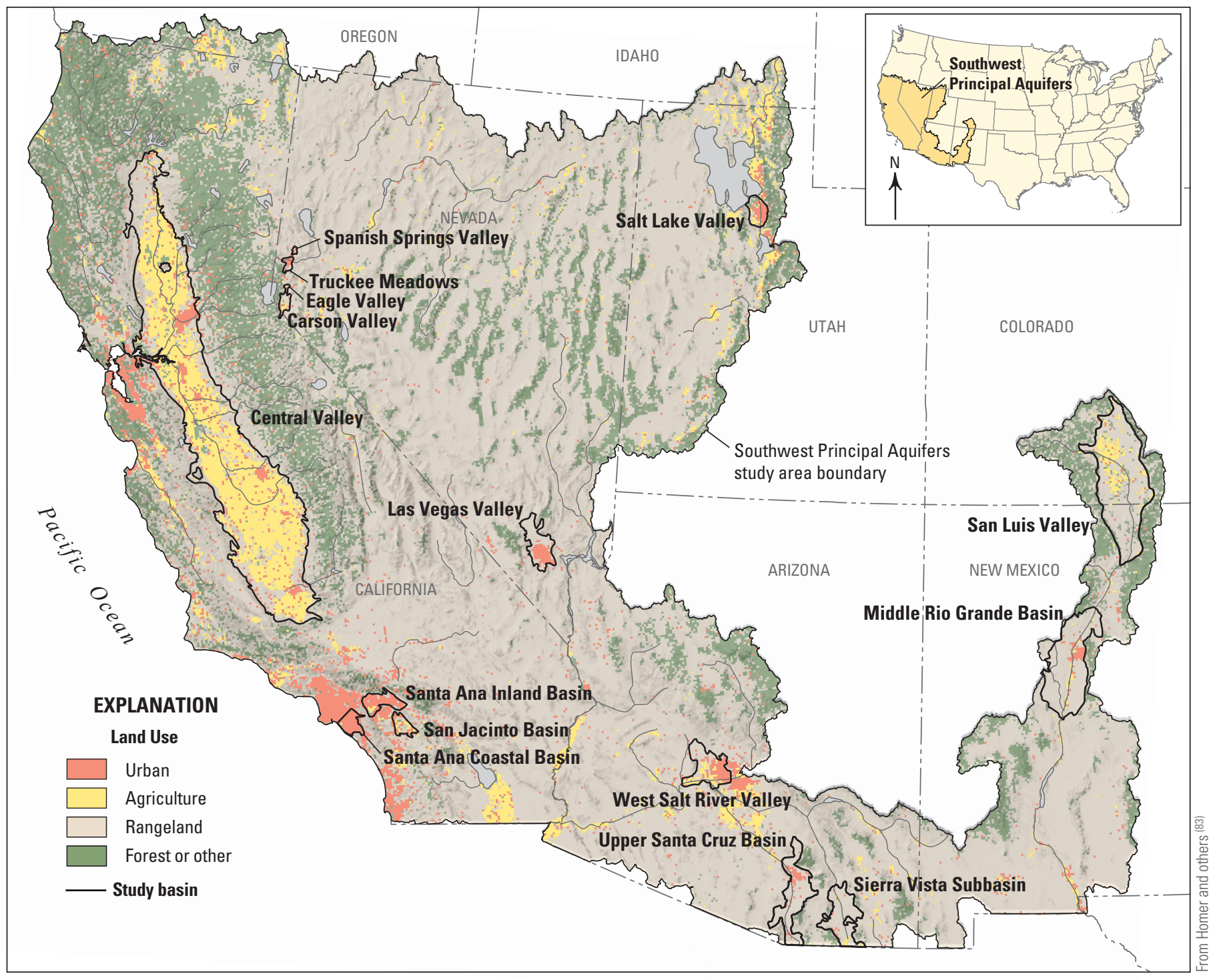

Figure 3-4. Urban and irrigated agricultural lands are focused mostly in areas where water (surface water, groundwater, or both) is accessible. Sagebrush and other rangeland and desert vegetation cover much of the alluvial basins in the Southwest. Forests are restricted to mountainous areas. 


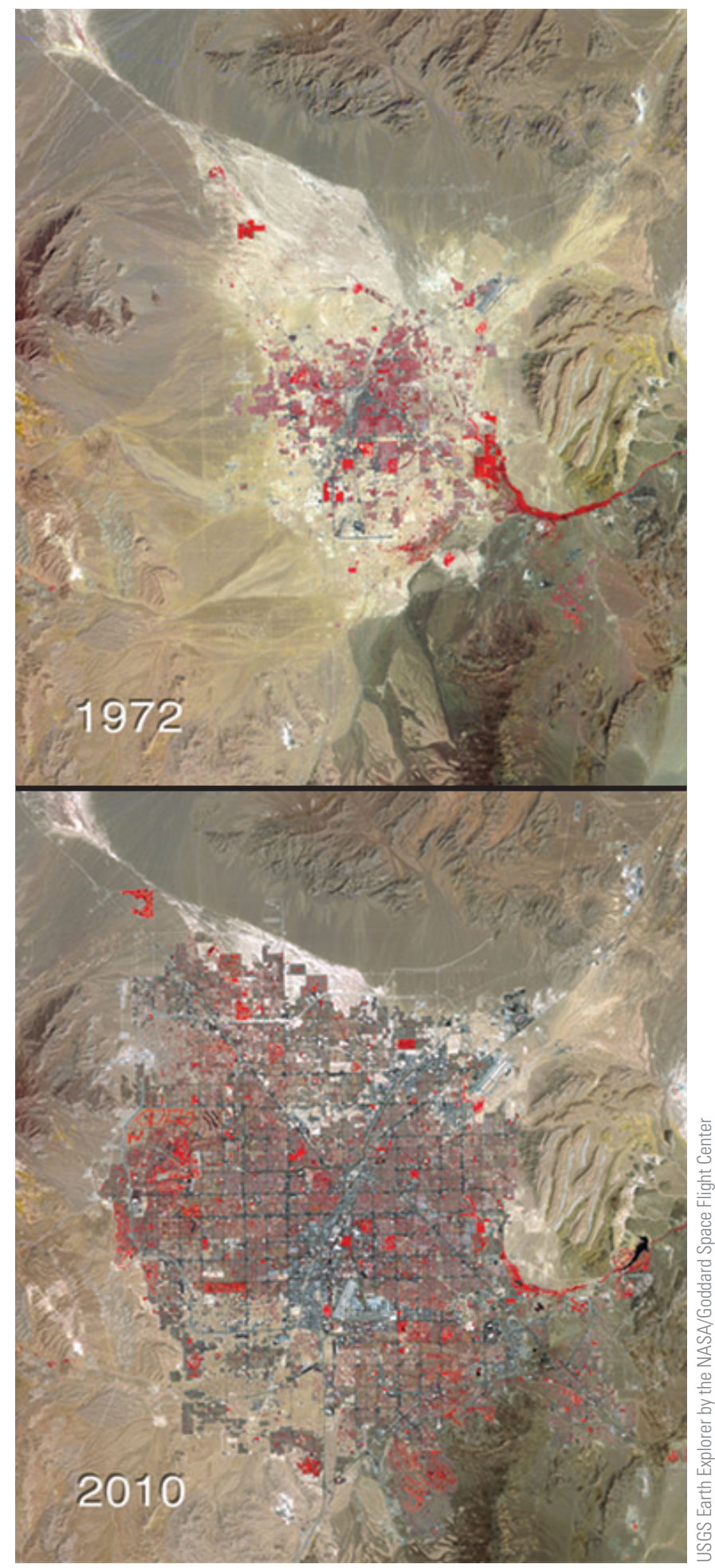

particular, along rivers and streams that are used to supply irrigation water to fields. Irrigation is required to grow crops in most areas of the Southwest and even prehistoric farmers, such as the Hohokam culture in central and southern Arizona, diverted water to their fields. ${ }^{(10)}$ Among the study basins, agricultural land area ranges from less than 2 percent of the Las Vegas Valley to about 61 percent of the Central Valley. Agricultural production in the Central Valley in 2007 was valued at $\$ 28$ billion, more than 75 percent of the total value of crop production for California and more than that for any other State in the Nation.(11) Irrigated agricultural land is rapidly being urbanized in much of the Southwest. For example, as more people have moved to the Central Valley - its population was more than 6 million in 2005-the towns and cities have encroached onto what previously was agricultural land. As another example, cropland in Maricopa County, Arizona, which is where the metropolitan Phoenix area is located, was reduced by $140 \mathrm{mi}^{2}$ or 67 percent from 1997 to 2007.(12)

"By the use of all the perennial streams during the season of irrigation, by the storage of the surplus water that runs to waste in seasons when irrigation is not practiced, by the impounding of the storm-waters, by the recovery of the floods accumulated in valley sands, and by the utilization of the artesian fountains, a vast area of the arid lands will ultimately be reclaimed and millions of men, women and children will find happy, rural homes in the sunny lands."

- John Wesley Powell, The Irrigable Lands of the Arid Region published in 1890 in the Century Illustrated Monthly Magazine.

The Las Vegas Valley, Nevada, population has grown from 273,000 people in 1972 to more than 2 million in 2010 . Areas of irrigated vegetation are shown in red and impervious surfaces, such as roads, are shown in gray on these Landsat satellite images. The large irrigated areas mostly are golf courses and city parks. 
Because the amount of surface water available in the arid to semiarid area is limited, cultural and economic activities in the region are particularly dependent on good-quality groundwater. In 2000, about 20,000 million gallons per day (23.0 million acre-feet per year) of groundwater was used in the Southwest Principal Aquifers study area. Water pumped from the basin-fill aquifers for irrigation and public supply (fig. 3-5) accounted for about one-quarter of the total withdrawals for these purposes from all aquifers in the United States. (13) Although the primary uses of groundwater in the Southwest are irrigation and public supply, water use varies locally by basin, and withdrawals for industrial uses, mining, and electric power generation are substantial in some areas.

Much of the population of the arid to semiarid Southwest relies on good-quality groundwater because of limited surface-water supplies.

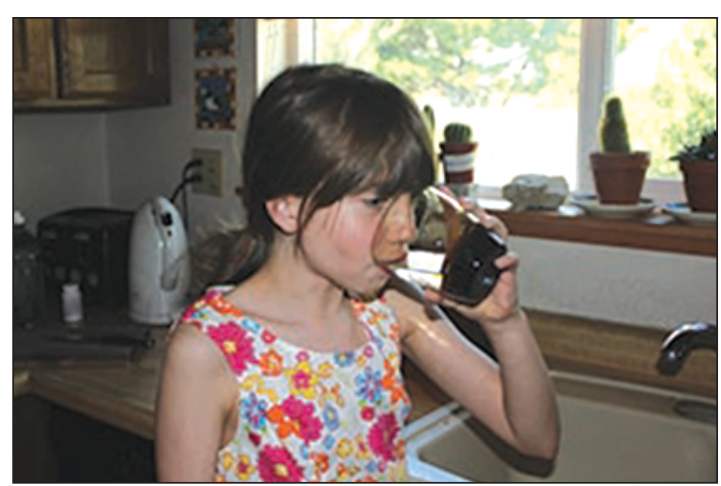

Groundwater withdrawals in Southwest Principal Aquifers

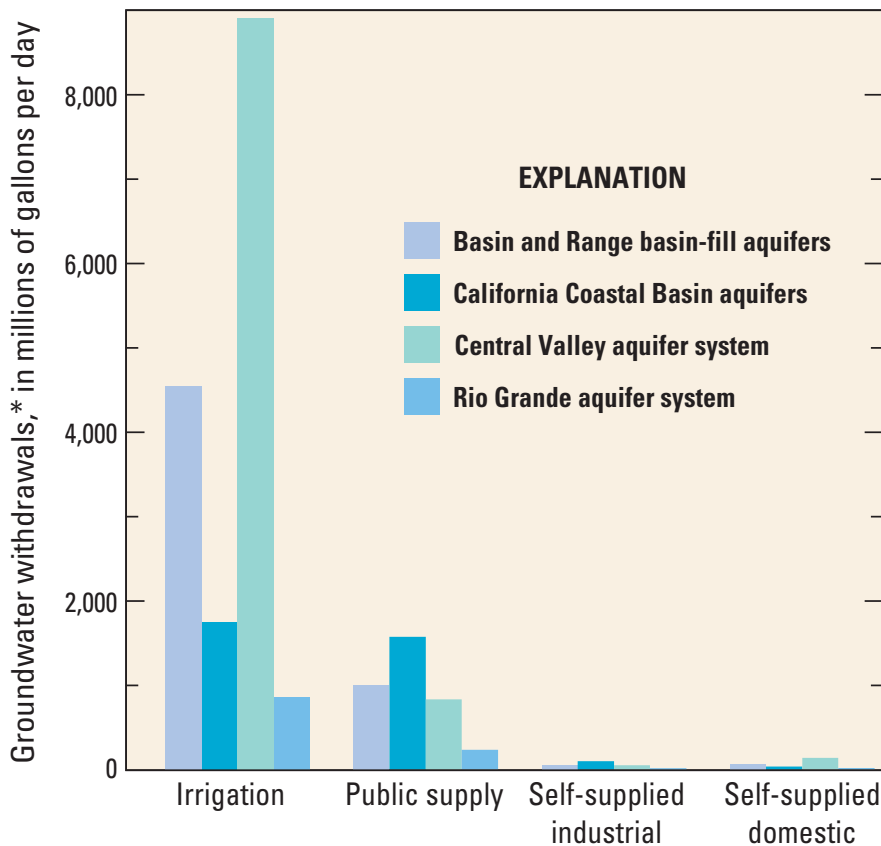

* Self-supplied domestic withdrawal data as of 2005; all other withdrawal data as of 2000 .

Figure 3-5. About 98 percent of the water pumped from Southwest Principal Aquifers is used for irrigation and public supply. (13) In 2005, however, about 1.4 million people in mostly rural areas relied on domestic wells that tap basin-fill aquifers-these wells are not routinely monitored for water quality.(52) 


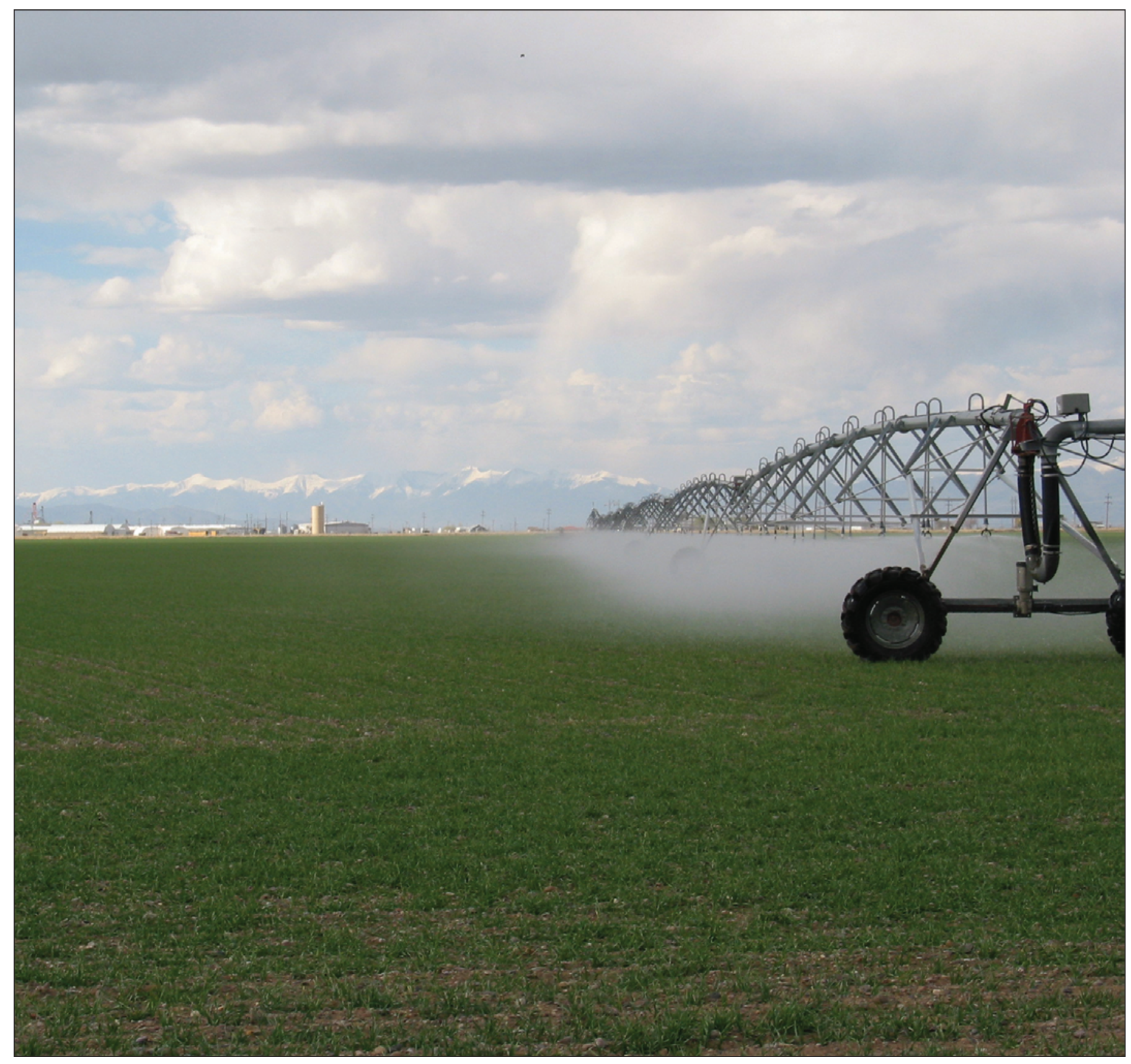

Sprinkler irrigation is common in the San Luis Valley of south-central Colorado and in many other basins in the Southwest where agriculture is prevalent. Pumping for irrigation has caused groundwater-level declines in some basins, and recharge of excess irrigation water can transport agricultural chemicals that are applied on the cropland to the groundwater below. 


\section{Chapter 4: The Hydrology of Southwest Basin- Fill Aquifers and How Human Alterations Affect Groundwater Quality}

$\mathrm{G}$ roundwater in Southwest basin-fill aquifers flows from recharge areas near the mountains to discharge areas in the valley lowlands in hundreds of individual basins. Each basin is unique, but natural hydrologic conditions and geochemical processes affect groundwater flow and quality in similar ways. The susceptibility of the aquifers to contaminants from geologic sources and from the land surface is controlled by these factors. Human activities in some basins - especially irrigation and pumping - have profoundly altered natural aquifer systems by increasing groundwater flow volumes and rates and introducing new contaminants.
This chapter explains and discusses the hydrologic and geochemical processes and human activities that affect the movement and quality of groundwater in Southwest basin-fill aquifers.

Much of the information presented in this chapter is from the report "Effects of natural and human factors on groundwater quality of basin-fill aquifers in the southwestern United States-Conceptual models for selected contaminants" (available at http://pubs.usgs.gov/sir/2011/5020/).

Agricultural and urban development in many Southwest basins has changed the water quality of the basin-fill aquifers. Groundwater recharged to and pumped from the aquifers has enhanced the movement of water and chemicals from the land surface to parts of the aquifers used for water supply. The Arizona Canal and irrigated fields near Scottsdale, Arizona, are shown. 


\section{Natural Hydrologic Settings and Geochemical Processes Are Key to Groundwater Flow and Quality}

Under natural conditions - that is, where human development has not altered the hydrology - recharge to basin-fill aquifers originates mostly as precipitation on the surrounding mountains that runs off and infiltrates into the coarse-grained stream-channel and alluvial-fan deposits near the basin margins (figs. 3-3 and 4-1A). Little of the precipitation that falls on the basin floor in drier areas becomes groundwater recharge because most of the water evaporates or is transpired by plants (evapotranspiration) before it infiltrates down to the water table. In wetter areas, such as parts of the Central Valley, there is more groundwater recharge from precipitation on the basin. Groundwater discharge under natural conditions typically is through evapotranspiration and seepage to streams and springs in basin lowlands. The presence of groundwaterfed streams or springs that flowed year round in the early days of the settlements are why the cities of Las Vegas, Nevada; Tucson, Arizona; and San Bernardino, California, are located where they are.

Potential evapotranspiration - the amount of water that would evaporate and transpire if unlimited water were available - can greatly exceed the average annual precipitation in most Southwest basins. For example, potential evapotranspiration in Las Vegas Valley in southern Nevada is almost
$100 \mathrm{in} / \mathrm{yr}$, but average annual precipitation is less than $12 \mathrm{in} / \mathrm{yr}$ (fig. 3-1). This means that all of the water from precipitation in this basin potentially can evaporate, leaving behind any dissolved minerals that the water contained. Over time, these minerals build up in the soil and unsaturated zone. Recharge from large rains or from irrigation moves the minerals down through the unsaturated zone, delivering pulses of highconcentration solutes to the water table.

There are few, if any, ways that surface water and groundwater can leave constricted or closed basins other than by evapotranspiration, and so constituents accumulate in these basins and aquifers. Less accumulation occurs in open basins, where dissolved constituents can be flushed out of the basin and aquifer by discharge to streams or by subsurface outflow. Of the 15 Southwest study basins, only parts of the Central Valley and San Jacinto Basin in California and the San Luis Valley in Colorado are closed under most conditions. However, more than 50 basins in the southwestern United States have no natural outflow other than by evapotranspiration(14) and, therefore, are especially vulnerable to the accumulation of dissolved constituents, some of which are potentially harmful at elevated concentrations.

\author{
Evaporative concentration of dissolved \\ constituents can contaminate groundwater.
}

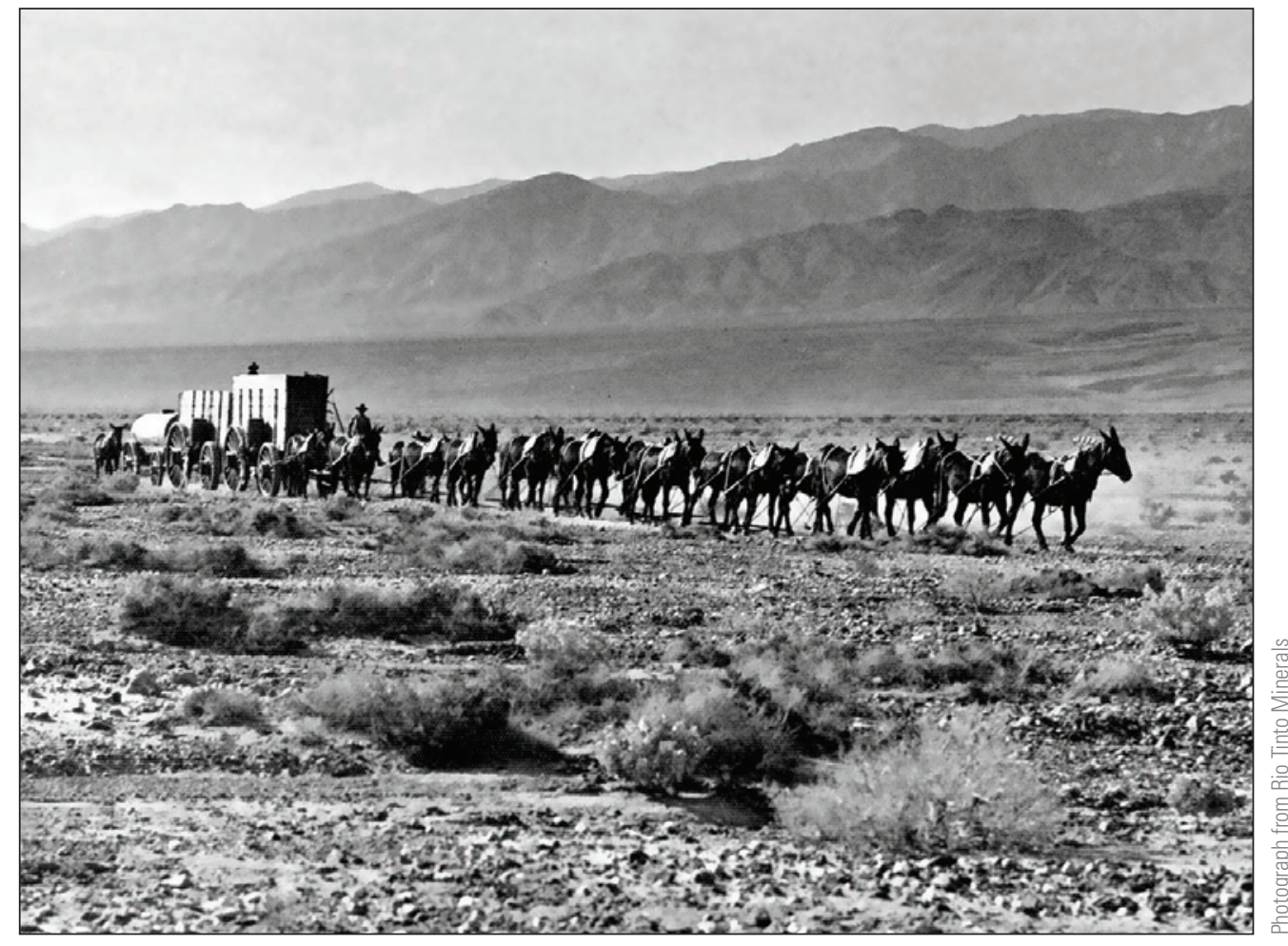

Large deposits of borax, a mineral that contains boron, have formed by repeated evaporation of saline lakes in closed basins in desert regions in California and Nevada. The use of borax in a wide variety of commercial products was popularized by the famous 20 Mule Team Borax trademark, which was based on the early use of mules to haul borax from the mines. 


\section{A. Predevelopment conditions in the Central Valley, California-Balanced groundwater budget}

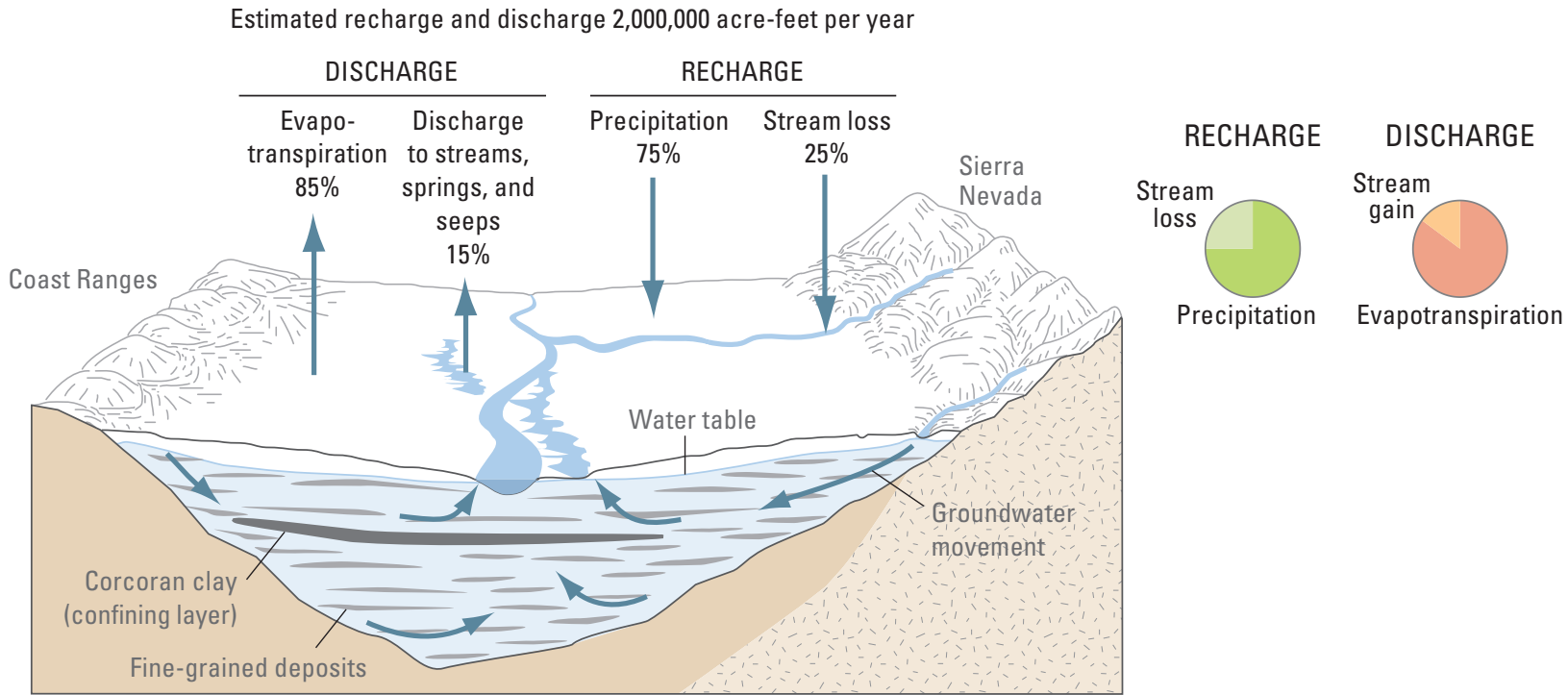

NOT TO SCALE

B. Modern conditions in the Central Valley, California-As a result of pumping and irrigation, about seven times more groundwater now moves through the aquifer than before development of water resources

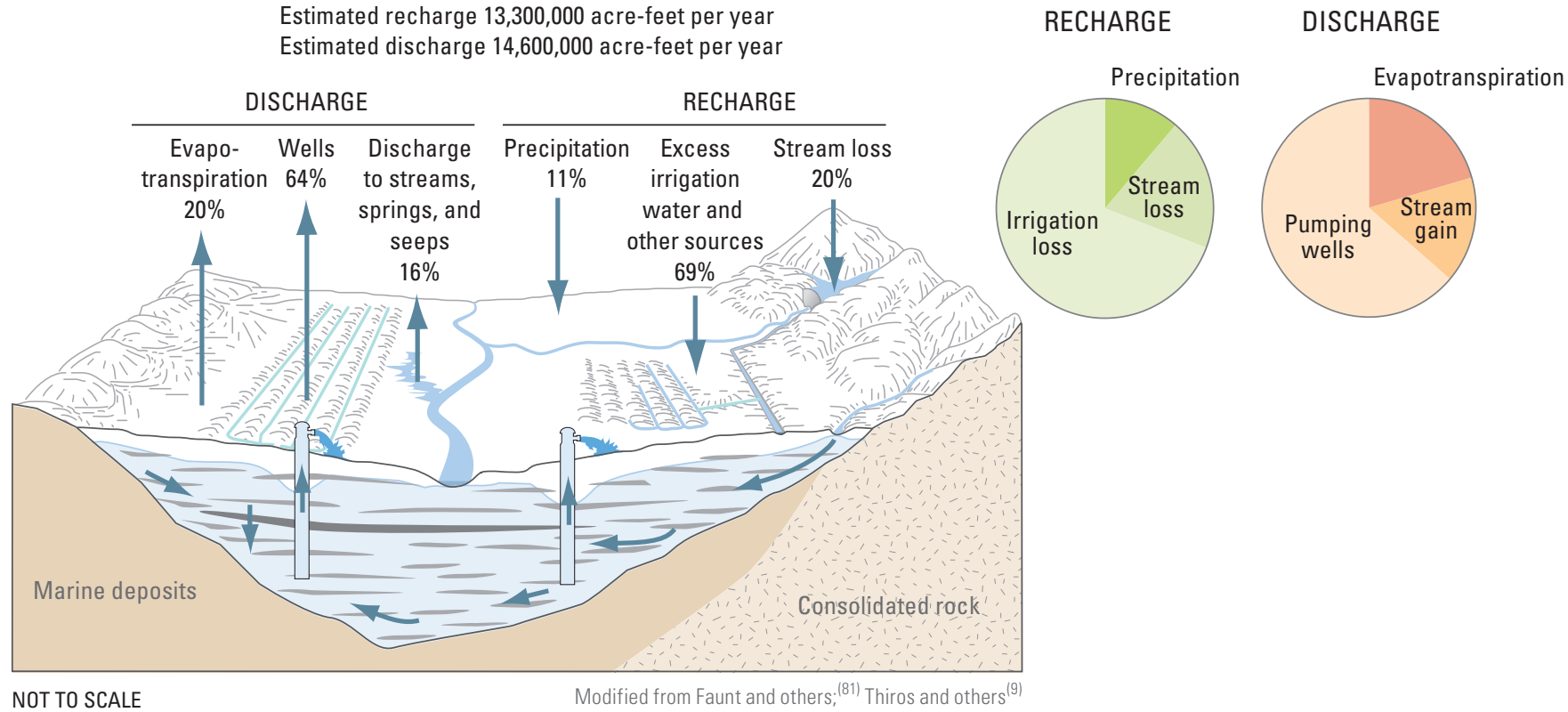

Figure 4-1. Before extensive modification of some groundwater systems began in the 1800s and early 1900s, the quantity of water that came into Southwest basin-fill aquifers was about the same as the quantity that went out. An example is shown here of the Central Valley in California. $A$, Before development, natural processes in the basin and surrounding mountains controlled the hydrology. $B$, Agricultural and urban activities have greatly altered the modern hydrologic system in the basin, increasing downward groundwater flow. 


\section{Hydrogeologic Factors Control the Susceptibility of Groundwater to Contamination}

Groundwater and the dissolved constituents it contains flow relatively rapidly through coarse-grained sediment, such as sand and gravel. Basin-fill aquifers in the Southwest generally contain more sand and gravel near the basin margins and along stream channels and more fine-grained layers in and near the basin lowlands (fig. 3-3). Confining layers or lenses of silt and clay slow the downward movement of groundwater and contaminants. As a result, in parts of basins where confining layers are present, deep groundwater is less susceptible to contamination from the land surface than shallow groundwater.

Rates of recharge to and discharge from aquifers and the presence of confining layers are natural controls on the general direction and amount of groundwater flow. Groundwater moves downgradient from higher altitude recharge areas, which in Southwest basins occur along basin margins, to lower altitude discharge areas, which occur in the basin lowlands (fig. 3-3). Confining layers can create artesian conditions in underlying parts of an aquifer, resulting in upward hydraulic gradients (upward flow) in discharge areas (see sidebar, Aquifer, p. 20). Upward hydraulic gradients inhibit the downward movement of contaminants, whereas downward gradients enhance contaminant movement to deeper parts of an aquifer.

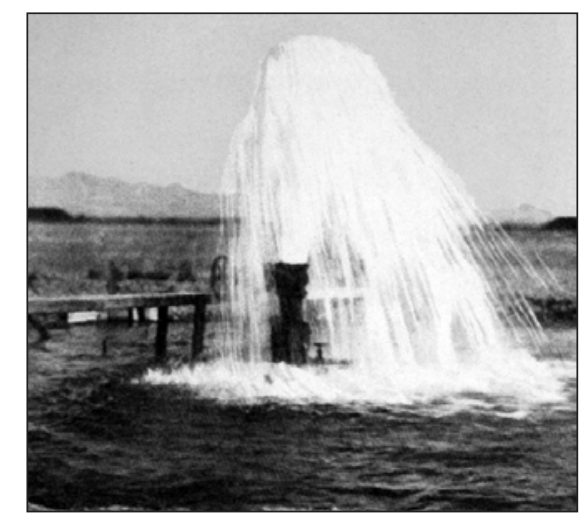

In the early 1900s, several uncapped artesian wells (wells that tap a confined part of the aquifer) near the center of Las Vegas Valley, Nevada, flowed freely. The Eglington well was flowing at about 615 gallons per minute when this photograph was taken in 1912 (from Carpenter(53)). Intensive groundwater withdrawals in the basin, first for irrigation and then for public supply, lowered the pressure in the aquifer and caused flow from the artesian wells and most springs to cease by the early 1970s. (54)
The thickness of the unsaturated zone, which corresponds to the depth to the water table (see sidebar, Aquifer, p. 20), influences subsurface water flow and contaminant movement in Southwest basins. Under natural conditions, groundwater in Southwest basins is up to several hundred feet below land surface in upland and mountain front areas near the basin margins and generally less than $50 \mathrm{ft}$ beneath the valley floor in the basin lowlands. Because the unsaturated zone typically is thin in the basin lowlands, contaminants at the land surface in these areas can move readily to shallow parts of an aquifer if there is any recharge. However, an upward hydraulic gradient and confining layers in discharge areas often impede the downward movement of groundwater to depths used for water supply. Near basin margins, recharge water travels downward through the thick unsaturated zone to the water table. A potentially long travel time through the unsaturated zone increases the likelihood that some contaminants will degrade or be removed from the water by interaction with aquifer solids during infiltration. On the other hand, the lack of substantial fine-grained layers coupled with a downward hydraulic gradient in areas near the basin margin can make the water table and unconfined part of the aquifer more susceptible to contamination by chemicals that might be transported through the unsaturated zone.

A low natural groundwater recharge rate, typical of many basins in the Southwest, combined with a large aquifer storage capacity, results in a long groundwater residence time. Groundwater residence time refers to the length of time water remains in an aquifer from recharge to discharge. Long residence times allow more time for groundwater to interact with aquifer sediments, resulting in concentrations of dissolved constituents that increase along groundwater flow paths. Groundwater throughout large parts of Southwest basins can be quite old - on the order of tens of thousands of years (fig. 4-2) - implying that some of the water was recharged during the last ice age when conditions in the Southwest were considerably cooler and wetter. This old groundwater was recharged prior to human development in the basin and has been isolated from human-related chemicals used at the land surface. If contamination of this deep groundwater occurs, however, the effects on groundwater quality can continue for a long time. 


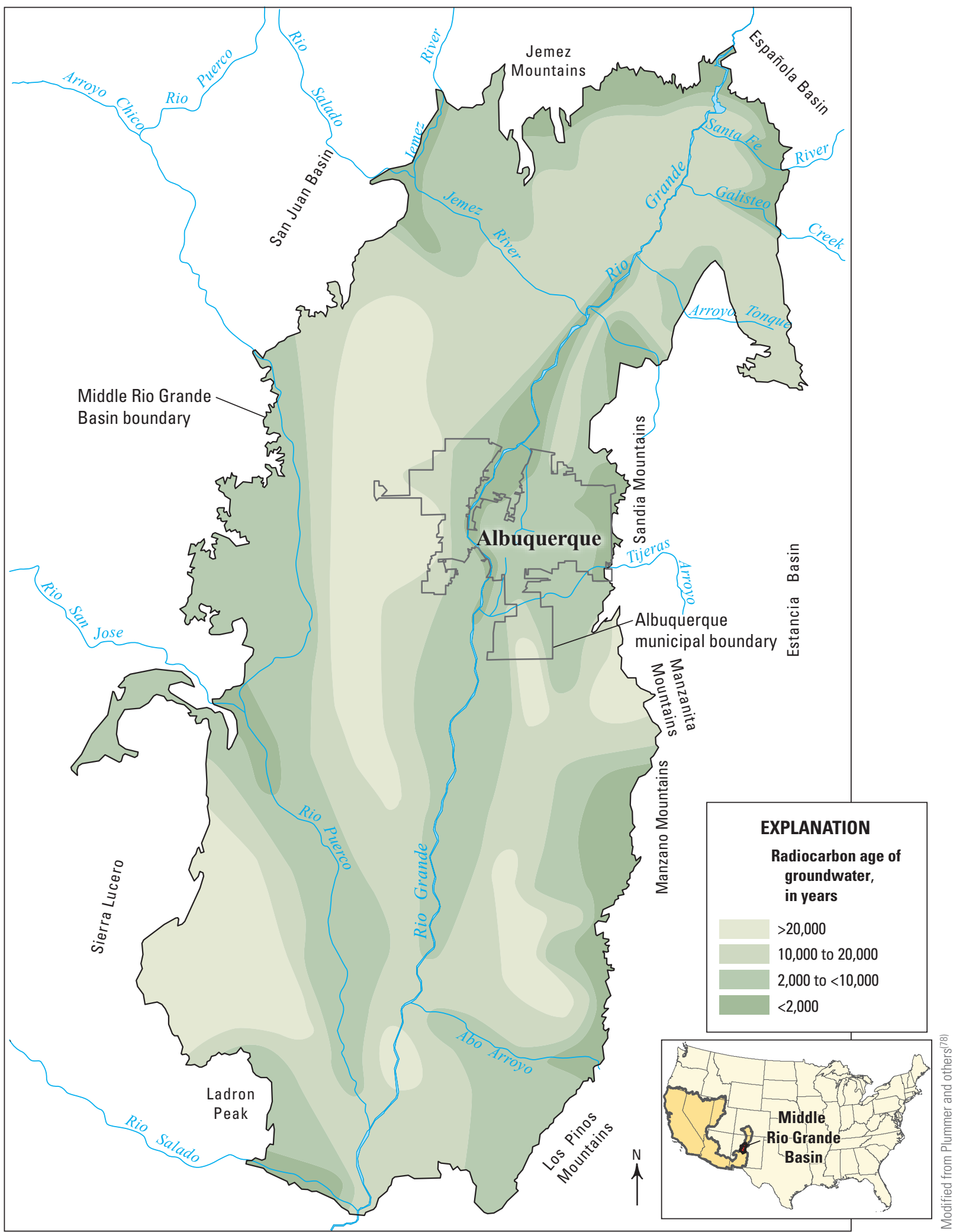

Figure 4-2. Groundwater throughout much of the Middle Rio Grande Basin in New Mexico is at least 10,000 to 20,000 years old, as determined from carbon-14 data. Some parts of the basin contain young groundwater (recharged since about 1950), particularly along the mountain fronts, near arroyos (intermittent or ephemeral streams), and in the Rio Grande inner valley where recharge occurs and the water table is generally less than about 30 feet below land surface. This young groundwater is more vulnerable to the effects of human-related activities at the land surface than is the very old groundwater. 


\section{Geochemical Conditions Are Important Controls on Contaminant Transport}

Geochemical conditions, such as $\mathrm{pH}$ (a measure of acidity) and oxic or anoxic conditions, are important controls on contaminant transport and fate in groundwater. Under natural conditions, $\mathrm{pH}$ and reduction/oxidation (redox) processes (see sidebar, How do redox reactions work?, p. 31) in groundwater are determined largely by the chemical composition and organic-carbon content of surrounding rocks and sediments and by rates of recharge and discharge. Volcanic rocks typically cause groundwater to have a high $\mathrm{pH}$ (more basic). Low rates of natural recharge to many Southwest basin-fill aquifers result in long groundwater residence times

Groundwater was
characterized as oxic
in about 70 percent of
wells sampled in the
Southwest. Oxic condi-
tions are associated with
high concentrations of
nitrate and uranium in
groundwater.
in parts of the aquifer and ample time for water/rock reactions that tend to increase $\mathrm{pH}$.

Oxic conditions predominate in Southwest basin-fill aquifers, whereas anoxic (reducing) conditions occur more commonly in glacial sand and gravel aquifers and consolidated rock aquifers in the central and eastern parts of the Nation.(15) Groundwater is considered oxic if the dissolvedoxygen concentration is equal to or greater than $0.5 \mathrm{mg} / \mathrm{L}$ and anoxic if the concentration is less than $0.5 \mathrm{mg} / \mathrm{L}$. Groundwater was characterized as oxic in about 70 percent of wells sampled in the Southwest for which water-level and dissolved-oxygen data were collected (fig. 4-3). Oxic conditions are associated with high concentrations of some contaminants, such as nitrate and uranium, in groundwater, but with low concentrations of others, such as petroleum hydrocarbons, by promoting their degradation. Under anoxic conditions, bacteria that thrive in groundwater with low concentrations of oxygen can degrade nitrate and some human-related compounds, such as solvents. (16) High $\mathrm{pH}$ or anoxic conditions promote desorption (detachment) of arsenic from aquifer sediments, elevating its concentration in groundwater (see Arsenic section in chapter 6).

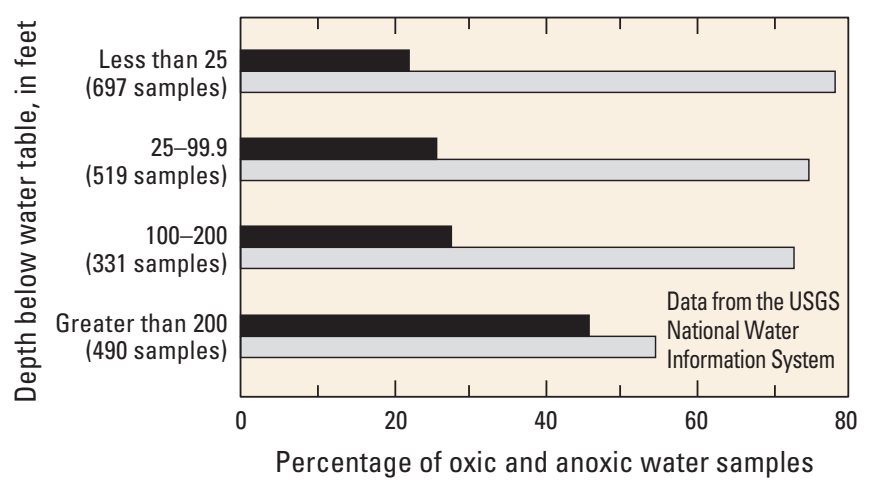

EXPLANATION

Oxic conditions-Dissolved-oxygen concentration equal to or greater than 0.5 milligram per liter

Anoxic conditions-Dissolved-oxygen concentration less than 0.5 milligram per liter

Figure 4-3. Groundwater in Southwest basin-fill aquifers is more commonly oxic than anoxic, especially at shallow depths. Anoxic conditions are more common at depth because the older, deeper groundwater has had more time for subsurface microorganisms to consume the dissolved oxygen. 


\section{How do redox reactions work?}

Reduction/oxidation (redox) processes require one chemical species that donates electrons and another chemical species that accepts those electrons. As a chemical species donates electrons it is "oxidized," and as the other species accepts electrons it is "reduced." Redox processes typically are facilitated by microbes (bacteria), which use the energy produced by the processes. In groundwater, organic carbon is the most common electron donor. If dissolved oxygen is present, it is the preferred electron acceptor, because reduction of dissolved oxygen produces more energy than reduction of other chemical species that commonly occur in groundwater. The atmosphere is the source of the dissolved oxygen, so the redox conditions in an aquifer near where recharge occurs usually are oxic (defined here as having a concentration of dissolved oxygen of at least $0.5 \mathrm{mg} / \mathrm{L}$ ).

\begin{tabular}{c|c|c|c|}
\hline Oxic & \multicolumn{3}{c|}{ Anoxic } \\
\hline Oxygen & Nitrate & Manganese Iron Sulfate & Carbon dioxide \\
\hline \multicolumn{4}{|c|}{ Order of consumption of electron acceptors } \\
\hline Oxic & $\begin{array}{c}\text { Mildly } \\
\text { reducing }\end{array}$ & $\begin{array}{c}\text { Strongly } \\
\text { reducing }\end{array}$ & $\begin{array}{c}\text { Very strongly } \\
\text { reducing }\end{array}$ \\
\hline
\end{tabular}

As groundwater moves through the aquifer along a flow path, the dissolved oxygen in the groundwater gradually is consumed by redox processes. Once all of the dissolved oxygen is consumed, other chemical species can accept electrons and become reduced. If nitrate is present, it will become the preferred electron acceptor until it in turn is completely consumed. This pattern continues, with manganese, iron, sulfate, and finally carbon dioxide acting as electron acceptors until they are consumed, in that order. This order of use of electron acceptors has important implications for the preservation, degradation, and even production of contaminants in groundwater. Because redox reactions occur in a sequence, it can take a long time for strongly reducing conditions to develop. For this reason, anoxic groundwater commonly is older than oxic groundwater, and, within the anoxic category, strongly reducing groundwater commonly is older than mildly reducing groundwater.

From a water-quality perspective, denitrification - the reduction of nitrate to nitrogen gas -is one of the most important redox processes that occurs in groundwater. Nitrate is a concern for human health and, where it discharges to surface water, can impair aquatic communities. Conversion of nitrate by denitrification to harmless nitrogen gas, the same gas we breathe in the atmosphere, is the primary way that nitrate is removed from water. 


\section{Human Activities Have Substantially Altered Groundwater Movement and Geochemistry}

The balance between recharge and discharge has changed in many basins because of the addition of artificial recharge water, increased groundwater withdrawals from pumping, or a combination of both (fig. 4-1B). Human activities associated with agricultural and urban uses have increased recharge across broad areas, caused waters from different sources and depths to mix, and enhanced water movement from the land surface down to aquifers used for water supply. Many human activities have introduced new sources of contaminants that, in combination with changes to the groundwater system, have made the groundwater more vulnerable to contamination.

\section{Artificial Recharge is a Major Source of Groundwater Recharge and Contaminants in Developed Basins}

There are many sources of artificial recharge to basin-fill aquifers in developed Southwest basins. These include the infiltration of excess irrigation water applied to crops and lawns; seepage and leakage from canals, water distribution pipes, sewer pipes, and septic-tank systems; infiltration of stormwater runoff from retention basins and recharge basins; seepage of treated wastewater through streambeds and irrigated fields; and infiltration of surface water and imported water from recharge ponds and injection wells. Artificial recharge has caused groundwater flow rates to increase, flow directions to change, and saturated thickness to increase or form "groundwater mounds" (and therefore thinner unsaturated zones) in some basin-fill aquifers. In some areas, this additional recharge results in more groundwater discharge to streams (see sidebar, Groundwater discharge can deliver contaminants to surface water, p. 36).

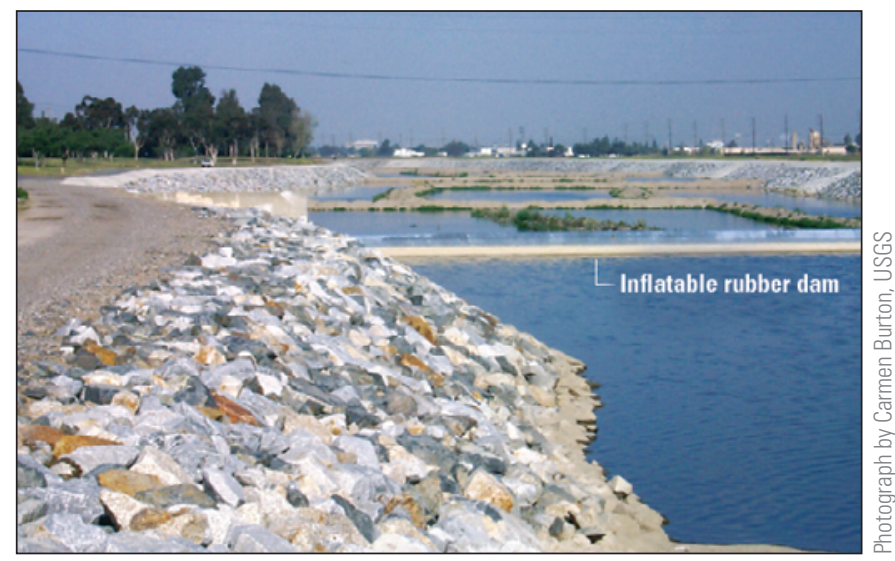

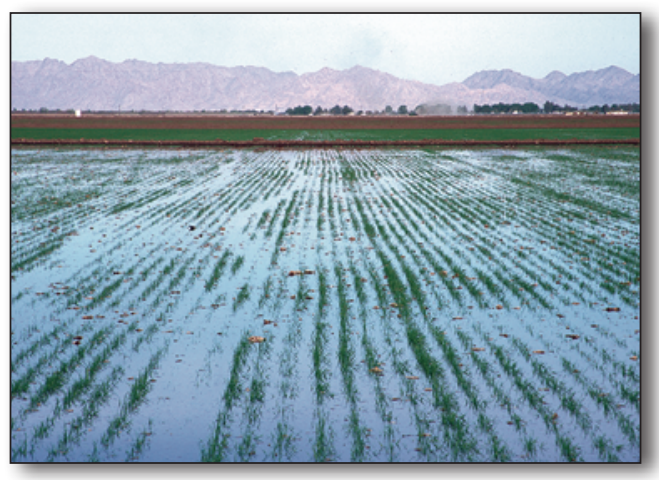

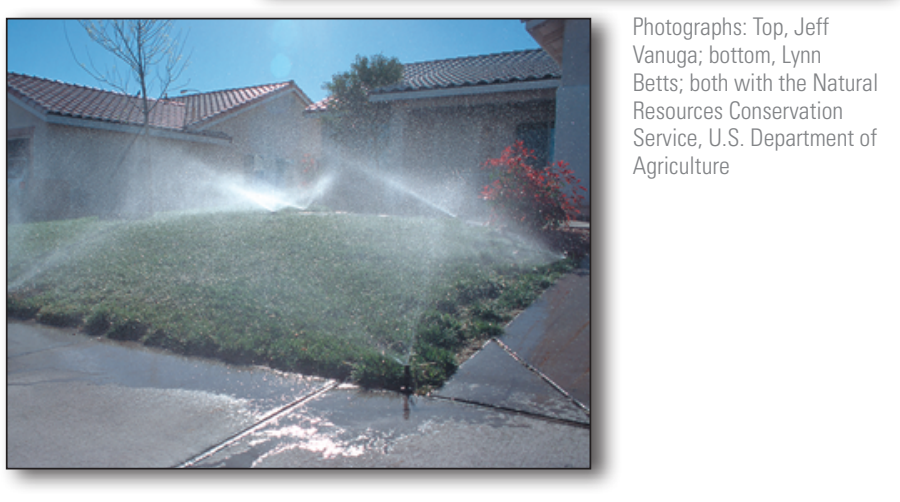

Excess irrigation water from agricultural and urban areas is a source of recharge to basin-fill aquifers. Top, flood irrigation on a wheat field in Yuma, Arizona; bottom, sprinkler irrigation on a lawn in Las Vegas Valley, Nevada.

In some basins, the amount of groundwater recharge from natural and artificial sources is about seven times that of natural recharge prior to water development.

An inflatable rubber dam along the Santa Ana River in California impounds water to be diverted into recharge ponds. Artificially recharged water, such as this, can move contaminants from treated wastewater, stormwater, and agricultural runoff into the aquifer. 
Irrigation, which is used on essentially all cropland in the arid to semiarid Southwest, enhances the movement of fertilizers, manure, and pesticides applied to crops through the soil zone and down into groundwater. Evaporative concentration of irrigation water increases concentrations of dissolved solids and, in some areas, other constituents in artificial recharge. For example, if crops are irrigated in areas where soils contain arsenic, the arsenic can be released from the soils into the shallow groundwater. In the southern Carson Desert, Nevada, groundwater levels have risen by about $15 \mathrm{ft}$ as a result of recharge from widespread irrigation in the area since the early 1900s. Evaporative concentration of irrigation water and release of arsenic from aquifer sediments have resulted in high concentrations of arsenic in the area's shallow groundwater. $(17,18)$

Human activities associated with urban and suburban land use can contribute contaminants from the land surface to groundwater. Stormwater runoff is a potential source of a variety of contaminants to groundwater recharging across broad areas or through streambeds and flood retention basins. Contamination also can occur from point sources, such as leaking storage or septic tanks, landfills, or accidental spills.

Artificial recharge has become a major source - and, in some cases, the primary source - of groundwater recharge in most of the 15 Southwest study basins.(19) Recharge from irrigation canals, irrigated agricultural fields, and urban turf areas currently provides at least half the recharge to basin-fill aquifers in the Central Valley, California; San Luis Valley, Colorado; and West Salt River Valley, Arizona. Nearly half of the groundwater recharge to the Santa Ana Coastal Basin in California (about 165,000 acre-feet per year) comes from engineered recharge facilities along and near the Santa Ana River. In the West Salt River Valley and Central Valley, the amount of groundwater recharge from natural and artificial sources is about seven times that of natural recharge prior to water development (fig. 4-4).

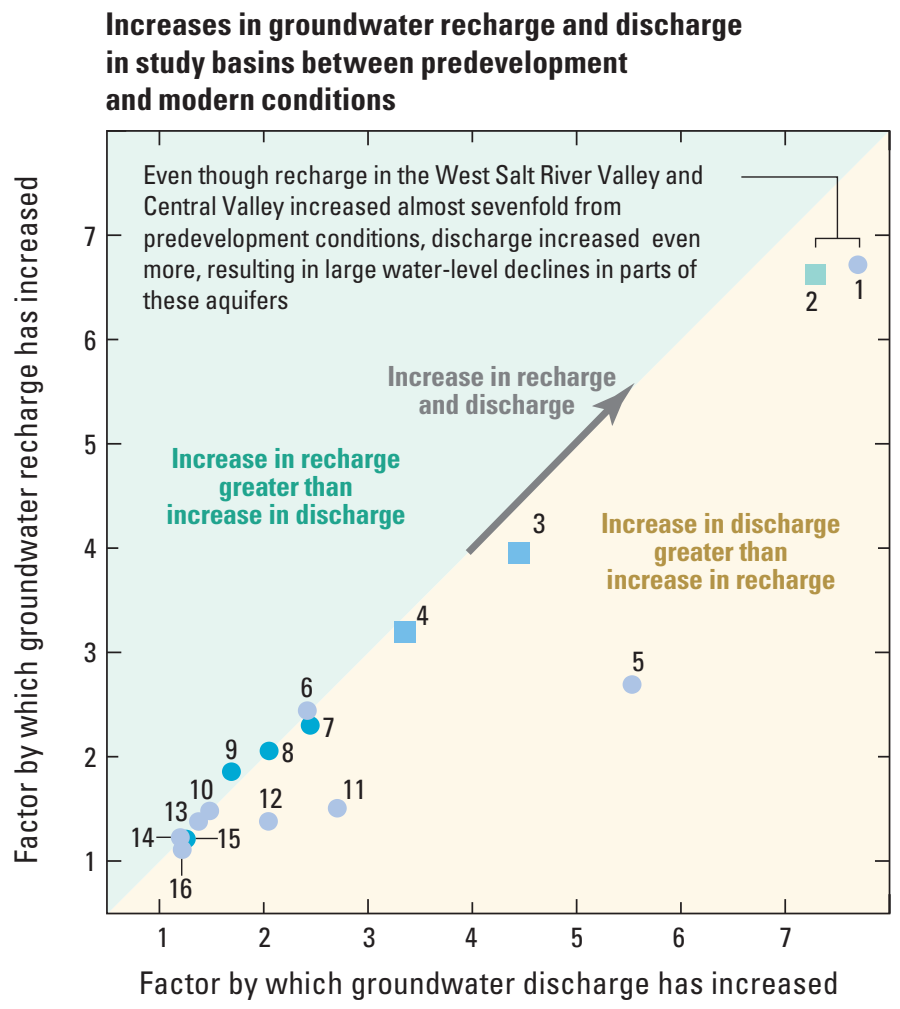

\section{EXPLANATION}

Study basin

1 West Salt River Valley

2 Central Valley

3 Middle Rio Grande Basin

4 San Luis Valley

- 5 Spanish Springs Valley

- 6 Las Vegas Valley

- 7 Santa Ana Inland Basin-Chino subbasin

- 8 Santa Ana Coastal Basin

- 9 Santa Ana San Jacinto Basin

10 Carson Valley

11 Upper Santa Cruz Basin

12 Sierra Vista subbasin

13 Salt Lake Valley

14 Truckee Meadows

15 Santa Ana Inland Basin-Bunker Hill subbasin

- 16 Eagle Valley

\section{Principal Aquifer}

- California Coastal Basin aquifers

- Central Valley aquifer system

- Basin and Range basin-fill aquifers

- Rio Grande aquifer system

Modified from Bexfield and others ${ }^{(19)}$

Figure 4-4. Water development in the Southwest study basins has caused increases in groundwater recharge, mostly from excess irrigation water, and discharge, by well pumping. As a result, downward movement of water has increased, increasing the vulnerability of the aquifers to contamination from chemicals used at the land surface. The distance along the diagonal from lower left to upper right indicates the amount of change in recharge and discharge since development of water resources in the basin. In most cases, increases in discharge exceed increases in recharge (yellow area of graph), which causes groundwater-level declines. 


\section{Pumping Changes Natural Groundwater Flow Systems}

Pumping wells have become the primary way that groundwater discharges from many Southwest basins, resulting in a decrease in natural discharge to streams and evapotranspiration. In most of the Southwest study basins, water pumped from wells accounted for more than half of the discharge from the basin-fill aquifers in 2000 (fig. 4-5). In many basins with pumping wells, the amount of groundwater stored in the aquifers has decreased because high pumping rates exceed any increases in recharge (fig. 4-4) - the groundwater discharge is from storage, and pumping is not sustainable. The largest estimated decrease in aquifer storage is in the Central Valley, where in some places groundwater levels have dropped more than $400 \mathrm{ft}$. Groundwater levels have dropped between 300 and $400 \mathrm{ft}$ in part of the West Salt River Valley, and declines of at least $100 \mathrm{ft}$ have been documented in parts of basins in Nevada (Las Vegas Valley), New Mexico (Middle Rio Grande), Arizona (Upper Santa Cruz), and elsewhere in California (Santa Ana Inland). Estimated groundwater residence times in the study basins under developed conditionsaffected by artificial recharge and groundwater pumping - are shorter than under predevelopment conditions. (19) As a result, groundwater moves through the aquifer more quickly, potentially transporting contaminants down to the groundwater supply. Geochemical conditions, such as redox and $\mathrm{pH}$, can be altered by oxygen-rich artificial recharge and water-level declines caused by pumping wells. Wells also can facilitate the movement of groundwater within an aquifer and allow the transport of oxygenated water to confined parts of an aquifer that previously was anoxic (see sidebar, Wells can "short circuit" groundwater flow paths and increase contaminant movement, p. 37).

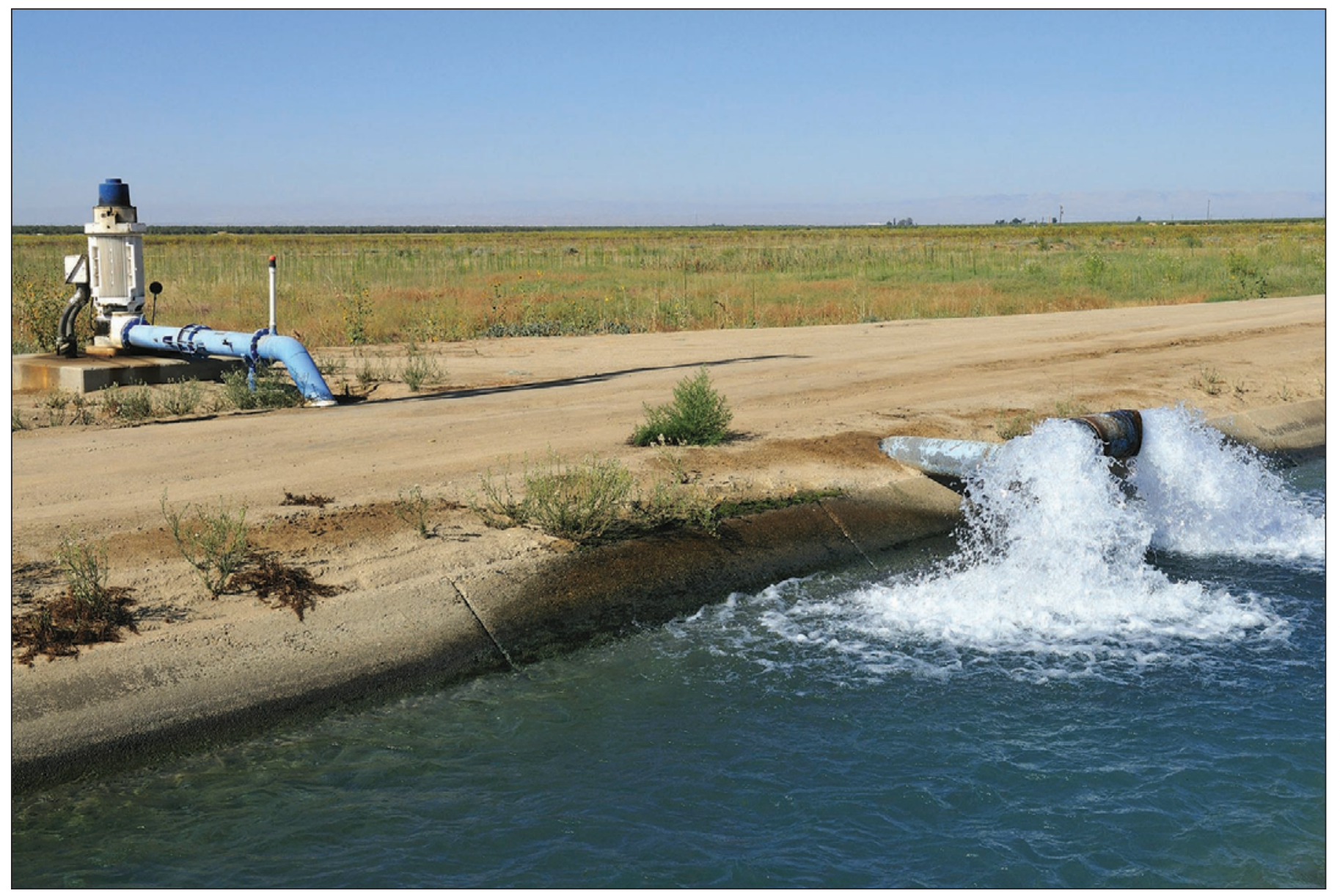

Turbine pumps capable of lifting groundwater from great depths became available in about 1930. By pumping the vast reserves of groundwater stored in the thick basin-fill aquifer, farmers have developed the San Joaquin Valley, California, into a major agricultural region. 
Estimated groundwater pumping from basin-fill aquifers (2000) and type of groundwater discharge in study basins

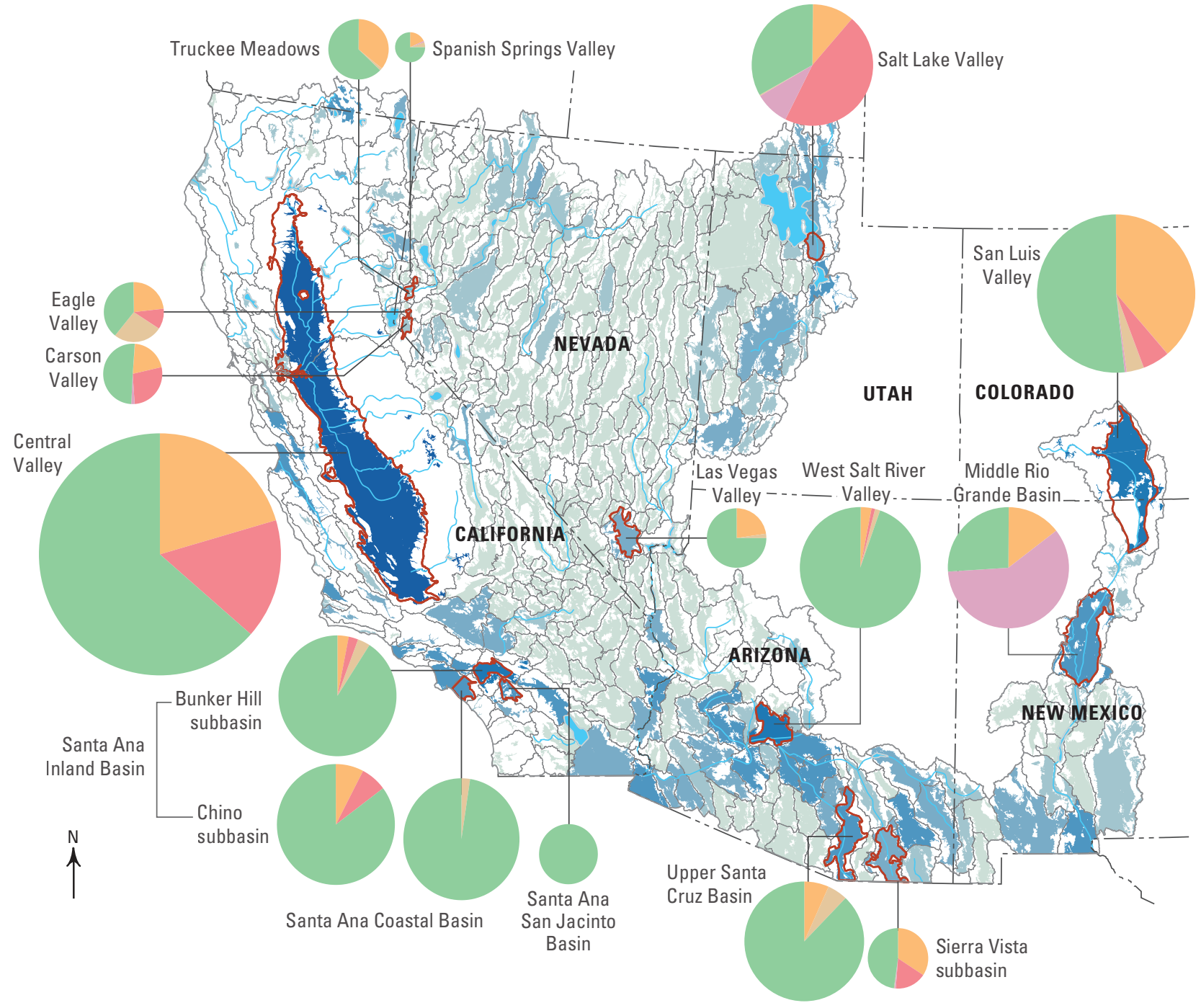

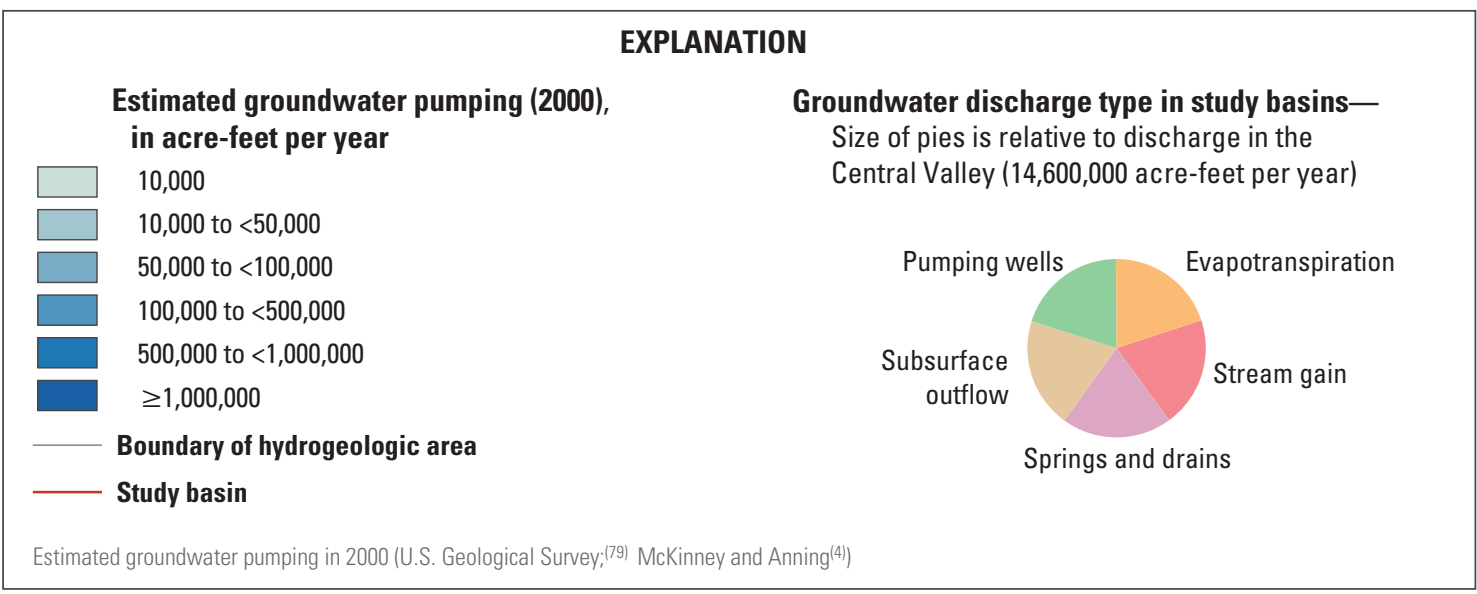

Figure 4-5. Pumping from wells is the primary way that groundwater discharges in 13 of 16 basins or subbasins with basin-fill aquifers studied in the Southwest. The largest withdrawals by pumping in 2000 occurred in the Central Valley of California. 


\section{Groundwater discharge can deliver contaminants to surface water}

Groundwater that discharges to streams can contain elevated concentrations of contaminants, such as dissolved solids and nitrate. Groundwater discharges naturally to streams in basin lowlands where the water table intersects the streambed. The amount of groundwater that discharges can be enhanced by irrigation in agricultural and urban areas, where large amounts of artificial recharge have caused groundwater levels to rise. The connection between groundwater and surface water is an important factor that can affect the quality of water in streams in Southwest basins.

In some irrigated agricultural areas, like the inner valley of the Rio Grande in New Mexico, ditches are used to intercept shallow groundwater, which contains high concentrations of dissolved solids. This water is diverted to the Rio Grande, thus increasing concentrations of dissolved solids in the river. In the Chino area of the Santa Ana Inland Basin, California, groundwater is a source of elevated concentrations of dissolved solids and nitrate in the Santa Ana River. Wells are used to decrease the volume of groundwater that discharges to the river, and desalination plants (desalters) are used to decrease concentrations of these constituents in the pumped groundwater.(55) (See Dissolved Solids section in chapter 6 for more information.)

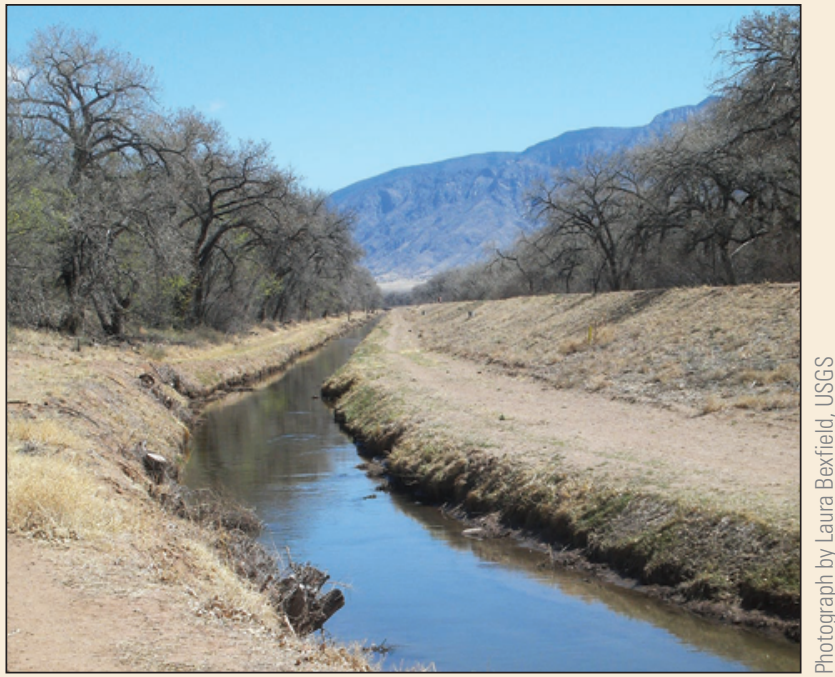

Ditches in the irrigated part of New Mexico's Rio Grande floodplain return shallow groundwater to the river, which is an important part of the public water supply in the Albuquerque area. The groundwater is recharged by excess irrigation water, which can contain elevated concentrations of dissolved solids.

\section{Human-induced changes to the Central Valley Aquifer System, California}

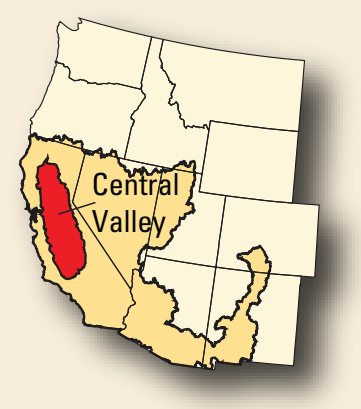

The intensely irrigated Central Valley, which includes the San Joaquin and Sacramento Valleys, is one of the most productive agricultural areas in the world - it produces 25 percent of the Nation's table food on only 1 percent of the country's farmland.(56) Before large-scale irrigation began in the area, the Central Valley aquifer system received most of its recharge

from precipitation and streams (fig. 4-1A). With development of water resources for irrigation and public supply, the infiltration of excess irrigation water has become the primary source of recharge to the aquifer system, and pumping from wells is now the primary discharge mechanism (fig. 4-1B). These human-induced changes - irrigation and groundwater pumping - have affected the geochemical conditions in many areas of the valley and increased the downward movement of shallow groundwater to deeper parts of the aquifer system.

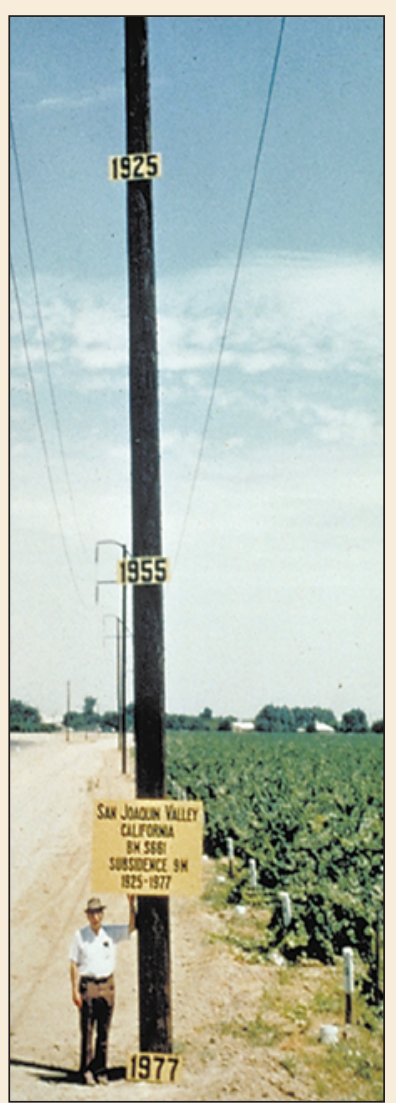

High rates of groundwater pumping are causing the Central Valley to sink. By 1970 , half of the entire valley had subsided a foot or more. Subsidence of more than 28 feet in the San Joaquin Valley southwest of Mendota, California, is the most subsidence measured anywhere in the continental United States (signs on the pole show the approximate altitude of the land surface in 1925, 1955, and 1977). The location was identified by the research efforts of Joseph Poland, U.S. Geological Survey (pictured). 


\section{Wells can "short circuit" groundwater flow paths and increase contaminant movement}

Pumping can alter the direction of groundwater flow within an aquifer. More unexpectedly, however, wellsparticularly those used for public supply or irrigation — can also affect groundwater movement when the wells are not being pumped, by providing pathways for movement of water and contaminants from one part of the aquifer to another.(57) The long open intervals of supply wells commonly span depths of the aquifer that differ in groundwater age, geochemical conditions, and concentrations of dissolved constituents. Where hydraulic gradients are downward, recharge water and young groundwater can move down in and along wells into deeper parts of aquifers, carrying contaminants to depths used for public supply. Where hydraulic gradients are upward, nonpumping wells can provide pathways for deeper, older water to move upward. The deep water could have elevated concentrations of constituents from geologic sources.

Downward migration of contaminants was found to occur at a public-supply well in the eastern San Joaquin Valley, California.(58) The VOC and pesticide compounds chloroform, perchloroethene, and deethylatrazine were

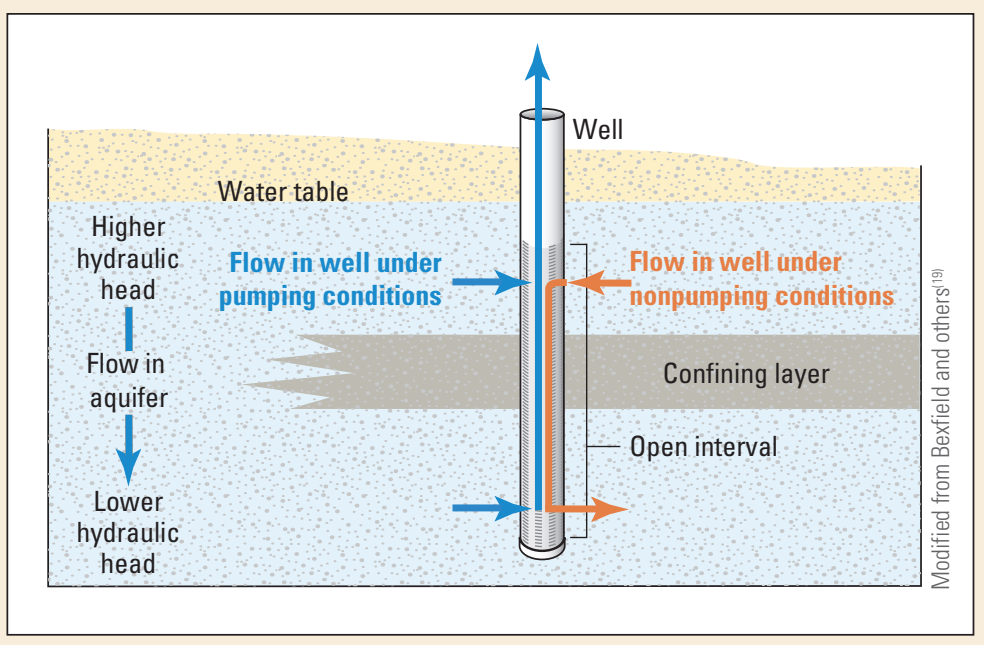

Groundwater flow can be "short circuited" through a well that is open to more than one depth in an aquifer. When the well is not being pumped, contaminants can move upward or downward, depending on the vertical hydraulic gradient, in and along the well, to parts of aquifer systems used for public supply. Downward flow in a well can occur even if there is a confining layer of clay within the aquifer if the well penetrates the confining layer. consistently detected in shallow parts of the aquifer. Only when the public-supply well was idle long enough to allow a substantial volume of water to migrate downward were these compounds also detected in water from a nearby deep monitoring well. 


\section{Chapter 5: Quality of Groundwater Used for Drinking and Irrigation in Southwest Study Basins}

$\mathrm{D}$ rinking water and irrigation are important uses of groundwater from the Southwest basin-fill aquifers. Does the quality of the groundwater support these uses? What are the constituents that might present human-health concerns when the water is used for drinking? What other constituents might adversely affect use of the water? In Southwest basin-fill aquifers, chemical constituents of concern for groundwater use originate from geologic sources (arsenic, uranium), human activities (pesticides, VOCs), or a combination of both natural and human sources (nitrate, dissolved solids).
This chapter identifies and discusses constituents that were detected at a concentration greater than or near a human-health benchmark in water from drinkingwater supply wells tapping several Southwest basin-fill aquifers.

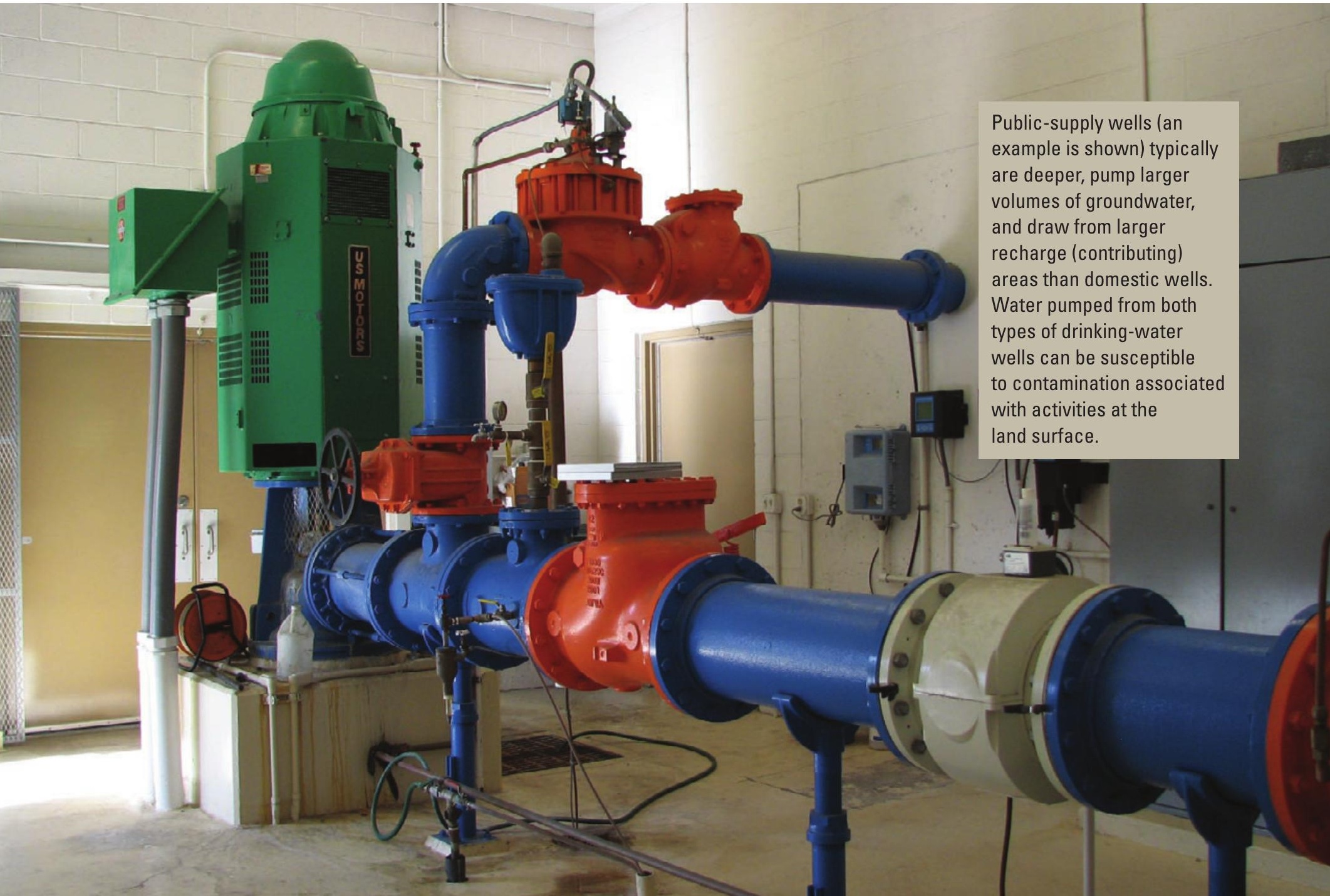


Water from about one in three drinking-water wells sampled in the Southwest Principal Aquifers study area contained at least one constituent at a concentration that exceeded its human-health benchmark.
About one in three (35 percent) of the drinking-water wells sampled in Southwest basinfill aquifers contained at least one constituent at a concentration greater than its human-health benchmark (table 5-1). Constituent concentrations exceeded benchmarks more frequently in domestic wells (42 percent) than in public-supply wells (26 percent). There were 257 instances in which a concentration exceeded a human-health benchmark in water sampled from more than 550 drinking-water wells (fig. 5-1; appendix 2, tables A2-2 and A2-3). Sixty-five percent of human-health benchmark exceedances were for a constituent from geologic sources - mostly arsenic and uranium, but also antimony, fluoride, manganese, molybdenum, radon using the proposed alternative MCL, and strontium. Twenty-four percent of human-health benchmark exceedances were for nitrate (natural and human-related sources), and 11 percent were for a manmade organic compound. Samples were collected prior to any water treatment or blending with other water sources to best represent water quality in the aquifer and do not necessarily represent the quality of water delivered to consumers.

Mixtures of contaminants from geologic sources, nitrate, VOCs, and pesticides at concentrations that exceeded benchmarks were present in many samples; 46 samples contained two contaminants and 11 samples contained three or four contaminants at a concentration that exceeded a benchmark (Appendix 2, fig. A2-1). Although human-health benchmarks have been developed for several individual contaminants, the health effects from drinking water with mixtures of contaminants are typically not known. Additional information for the primary contaminants - arsenic, uranium, nitrate, VOCs, and pesticides - measured at concentrations that exceeded human-health benchmarks and for dissolved solids is presented in chapter 6 .

Table 5-1. Twelve constituents were measured at concentrations greater than their human-health benchmarks in more than one drinking-water well quality in the aquifer and do not necessarily represent the quality of water delivered to consumers.

[MCL, Maximum Contaminant Level; $\mu \mathrm{g} / \mathrm{L}$, micrograms per liter; HBSL, Health-Based Screening Level; mg/L, milligrams per liter; pCi/L, picocuries per liter; AMCL,

\begin{tabular}{|c|c|c|c|c|c|}
\hline & \multicolumn{2}{|c|}{ Human-health benchmark } & \multirow{2}{*}{$\begin{array}{l}\text { Number of } \\
\text { drinking- } \\
\text { water wells } \\
\text { sampled }\end{array}$} & \multirow{2}{*}{\multicolumn{2}{|c|}{$\begin{array}{cc}\text { Benchmark } & \begin{array}{c}1 / 10 \text { th of } \\
\text { benchmark }\end{array} \\
\text { All aquifers in Southwest Principal } \\
\text { Aquifers group }\end{array}$}} \\
\hline & Type & Value & & & \\
\hline & & & & \multicolumn{2}{|r|}{ Contaminant from } \\
\hline Arsenic & MCL & $10 \mu \mathrm{g} / \mathrm{L}$ & 559 & 16 & 73 \\
\hline Uranium & MCL & $30 \mu \mathrm{g} / \mathrm{L}$ & 559 & 7.3 & 46 \\
\hline Manganese & HBSL & $300 \mu \mathrm{g} / \mathrm{L}$ & 564 & 3.2 & 11 \\
\hline Fluoride & MCL & $4 \mathrm{mg} / \mathrm{L}$ & 564 & 1.2 & 30 \\
\hline Molybdenum & HBSL & $40 \mu \mathrm{g} / \mathrm{L}$ & 559 & 1.1 & 27 \\
\hline Radon & Proposed MCL & $300 \mathrm{pCi} / \mathrm{L}$ & 430 & 86 & 100 \\
\hline \multirow[t]{2}{*}{ Radon } & Proposed AMCL & $4,000 \mathrm{pCi} / \mathrm{L}$ & 430 & 0.5 & 71 \\
\hline & & & & \multicolumn{2}{|r|}{ Contaminant from } \\
\hline *Nitrate & MCL & $10 \mathrm{mg} / \mathrm{L}$ as $\mathrm{N}$ & 554 & 11 & 63 \\
\hline Dibromochloropropane (DBCP) & MCL & $0.2 \mu \mathrm{g} / \mathrm{L}$ & 555 & 3.2 & 4.0 \\
\hline Dieldrin & HBSL & $\dagger 0.002 \mu \mathrm{g} / \mathrm{L}$ & 559 & 0.9 & 1.1 \\
\hline Perchloroethene (PCE) & MCL & $5 \mu \mathrm{g} / \mathrm{L}$ & 555 & 0.4 & 1.6 \\
\hline Trichloroethene (TCE) & MCL & $5 \mu \mathrm{g} / \mathrm{L}$ & 555 & 0.4 & 1.3 \\
\hline
\end{tabular}

* Nitrate also can occur naturally in groundwater from parts of Southwest basin-fill aquifers.

$\dagger$ Value is low end of range, associated with $10^{-6}$ cancer risk $^{(61)}$. 


\section{What is a contaminant?}

Contaminants have a wide range of sources, both manmade and geologic. Most organic chemicals in groundwater that are of concern for human health are manmade. In contrast, most inorganic constituents in groundwater have geologic or other natural sources, although their concentrations in groundwater may be altered by human activities, such as irrigation and groundwater pumping. Some contaminants have both manmade and natural sources. For example, nitrate in groundwater has many natural sources, but nitrate concentrations in groundwater underlying agricultural and urban areas commonly are higher than in other areas because of contributions from sources associated with human activities.

But what exactly is a contaminant? The word means different things to different people. For example, a contaminant is defined by the Safe Drinking Water Act (SDWA) as "any physical, chemical, biological, or radiological substance or matter in water" (see http://www.epw.senate.gov/sdwa.pdf). This broad definition of contaminant includes every substance that may be found dissolved or suspended in water-everything but the water molecule itself. This is not a very practical definition because this would imply that all water is "contaminated." Pure water that has nothing dissolved in it does not occur naturally —not even rainfall is pure water, because it contains, at a minimum, some dissolved gases.

The U.S. Environmental Protection Agency defines a contaminant as "Any physical, chemical, biological, or radiological substance or matter that has an adverse effect on air, water, or soil" (see http://epa.gov/region04/superfund/qfinder/glossary.htm/). This definition is more practical and allows both manmade constituents and those with geologic sources in water to be defined as contaminants. However, it does not define what "adverse" means, and what may be adverse in one way might be beneficial in another. In this circular, a contaminant is defined as any physical, chemical, biological, or radiological substance or matter in groundwater that is manmade or that impairs the use of water for its intended purpose. Impairment is determined by comparing a measured concentration to benchmarks or guidelines. By this definition, all manmade compounds, such as pesticides and volatile organic compounds, are contaminants because they do not occur naturally in groundwater. If a constituent with a geologic source, such as arsenic, occurs in drinking water at a concentration above its human-health benchmark, it also is considered a contaminant.

sampled in the Southwest. Samples were collected prior to any water treatment or blending with other water sources to best represent water

Alternative Maximum Contaminant Level; N, nitrogen; see figure 5-1 for the locations of the wells sampled]

Percentage of samples with concentrations that exceeded

\begin{tabular}{|c|c|c|c|c|c|c|c|}
\hline Benchmark & $\begin{array}{c}\text { 1/10th of } \\
\text { benchmark }\end{array}$ & Benchmark & $\begin{array}{c}\text { 1/10th of } \\
\text { benchmark }\end{array}$ & Benchmark & $\begin{array}{c}\text { 1/10th of } \\
\text { benchmark }\end{array}$ & Benchmark & $\begin{array}{c}\text { 1/10th of } \\
\text { benchmark }\end{array}$ \\
\hline \multicolumn{2}{|c|}{$\begin{array}{c}\text { Basin and Range basin-fill } \\
\text { aquifers }\end{array}$} & \multicolumn{2}{|c|}{ Central Valley aquifer system } & \multicolumn{2}{|c|}{ California Coastal Basin aquifers } & \multicolumn{2}{|c|}{ Rio Grande aquifer system } \\
\hline \multicolumn{8}{|c|}{ geologic sources } \\
\hline 22 & 74 & 7.3 & 82 & 2.7 & 46 & 39 & 94 \\
\hline 2.6 & 42 & 22 & 61 & 0.9 & 32 & 1.5 & 51 \\
\hline 0.4 & 3.9 & 2.6 & 10 & 7.1 & 21 & 7.5 & 19 \\
\hline 2.6 & 39 & 0 & 2.0 & 0 & 27 & 1.5 & 73 \\
\hline 1.3 & 27 & 0 & 10 & 1.8 & 37 & 1.5 & 46 \\
\hline 94 & 100 & 96 & 100 & 64 & 100 & 72 & 100 \\
\hline 0.5 & 82 & 0 & 83 & 1.1 & 45 & 0 & 41 \\
\hline \multicolumn{8}{|c|}{ human-related sources } \\
\hline 7.1 & 66 & 26 & 80 & 6.3 & 62 & 0 & 21 \\
\hline 0 & 0 & 10 & 13 & 1.8 & 1.8 & 0 & 0 \\
\hline 0 & 0 & 2.6 & 3.3 & 0 & 0 & 1.6 & 1.6 \\
\hline 0 & 0.9 & 0 & 0.7 & 1.8 & 5.4 & 0 & 0 \\
\hline 0 & 0.4 & 0 & 0 & 1.8 & 5.4 & 0 & 0 \\
\hline
\end{tabular}




\section{Percentage of drinking-water-well samples containing a contaminant at a concentration exceeding its human-health benchmark}

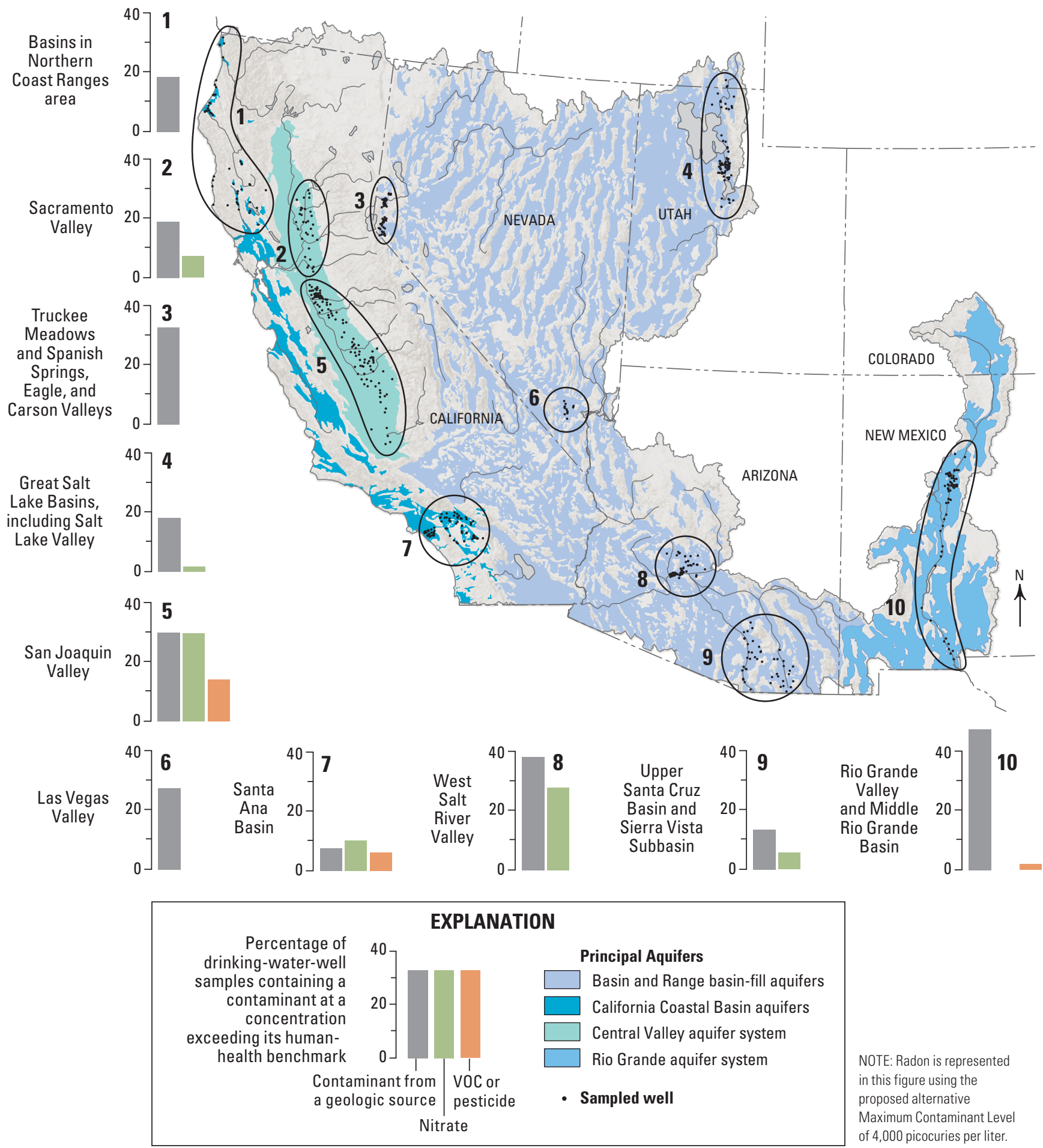

Figure 5-1. Concentrations in drinking-water wells of contaminants from geologic sources exceeded human-health benchmarks more frequently than those of contaminants from human-related sources in all of the Southwest study basins except for the eastern San Joaquin Valley, California. Human-related contaminants (nitrate, volatile organic compounds [VOCs], and pesticide compounds) exceeded benchmarks most frequently in this area of intense agricultural land use where shallow contaminated groundwater is moving deeper in the aquifer system (see chapter 6 for information on these contaminants in San Joaquin Valley groundwater). 


\section{Human-health benchmarks and other guidelines used in this assessment}

Concentrations of constituents measured for this assessment were compared to human-health benchmarks to place study findings in the context of human health. The benchmarks are threshold concentrations in water above which the concentration of a contaminant in drinking water could adversely affect human health. Human-health benchmarks were available for about two-thirds of the 287 constituents and properties measured for the Principal Aquifer assessments (see appendix 2, table A2-1, for list of constituents and properties analyzed). Two types of human-health benchmarks were used: U.S. Environmental Protection Agency (USEPA) Maximum Contaminant Levels (MCLs) (http://water.epa.gov/drink/contaminants/index.cfm) and U.S. Geological Survey (USGS) Health-Based Screening Levels (HBSLs). MCLs are legally enforceable drinking-water standards that specify the maximum permissible level of a constituent in water that is delivered to any user of a public water system(36) (values used in this report were current as of February 2012). Although MCLs are used to regulate the quality of drinking water only from publicsupply sources, they also are useful for evaluating the quality of water from domestic and monitoring wells. An MCL was available for 53 of the constituents measured. For some constituents for which an MCL has not been established, the USGS, in collaboration with the USEPA and others, developed non-enforceable HBSLs by using standard USEPA methods for establishing drinking-water guidelines and current toxicity information(59-61) (values used in this report were current as of February 2012; see http://water.usgs.gov/nawqa/HBSL). An HBSL was available for 135 of the constituents measured. Radon has neither an MCL nor an HBSL, but two MCLs have been proposed. Copper and lead have USEPA action levels rather than an MCL.

In addition to human-health benchmarks, non-healthbased guidelines-Secondary Maximum Contaminant Levels
(SMCLs) - were available for some of the constituents measured in this assessment. The SMCLs are non-enforceable guidelines for concentrations of "nuisance" constituents in drinking water that can cause unwanted cosmetic effects, such as skin or tooth discoloration; aesthetic effects, such as unpleasant taste, odor, or color; or technical effects, such as corrosion or sedimentation of plumbing or reduced effectiveness of water treatment. (23)

Concentrations greater than one-tenth of a human-health benchmark were used in this assessment to indicate which contaminants occurred, either individually or as mixtures, at concentrations that approach those of potential concern for human health, and to identify contaminants that might warrant additional monitoring and study. The criterion of one-tenth of a benchmark is consistent with various State and Federal practices for reporting contaminant occurrence in groundwater and for identifying contaminants of potential human-health concern (for example, see U.S. Environmental Protection Agency;(62) New Jersey Department of Environmental Protection(63)).

Screening-level assessments, such as this one, provide perspective on the potential relevance of detected contaminants to human health and can help in planning future studies.(60) They are not designed to evaluate specific effects of contaminants on human health and are not a substitute for comprehensive risk assessments. It is important to note that occurrence of a contaminant at a concentration greater than its benchmark does not mean that adverse effects are certain to occur, because the benchmarks are conservative (protective) and source-water samples were collected prior to any treatment or blending that could alter contaminant concentrations in finished drinking water. There are water treatment options, such as charcoal filtration, that can be used to lower the concentration of the contaminant to below the benchmark before the water is consumed.

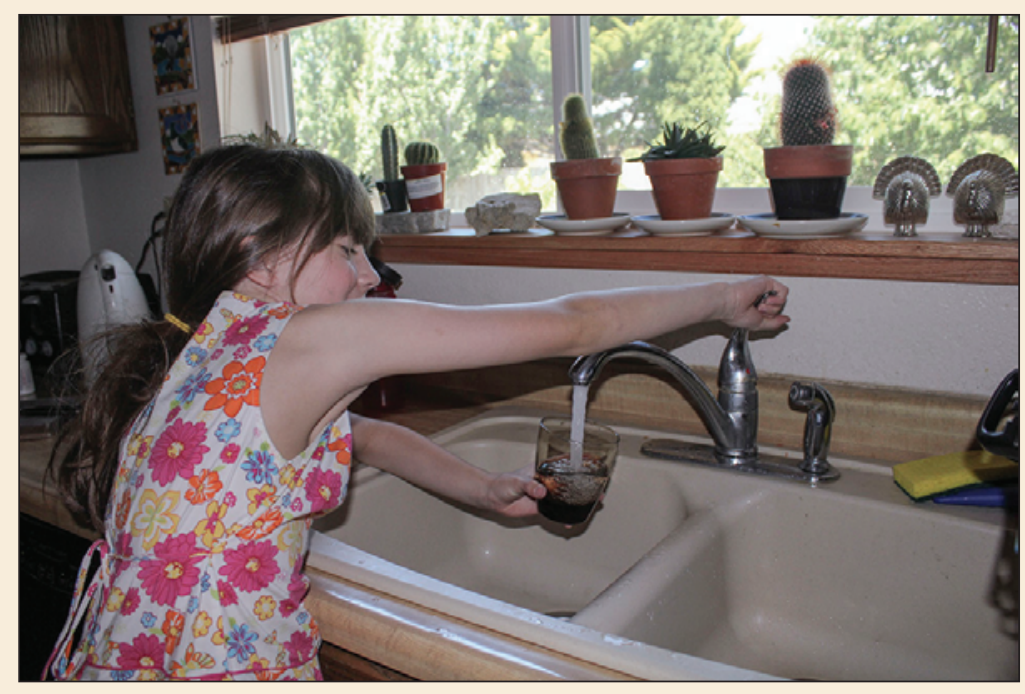




\section{Nitrate and Human-Related Organic Compounds}

Nitrate is a nutrient that has human-related sources, such as fertilizer and wastewater, but that also occurs naturally in parts of the Southwest. Elevated nitrate concentrations in drinking water can cause methemoglobinemia ("blue-baby" syndrome) in infants. Nitrate concentrations greater than the MCL $(10 \mathrm{mg} / \mathrm{L}$ as nitrogen [N]) were measured in 11 percent of Southwest drinking-water wells, ranging from 26 percent of samples from the Central Valley aquifer system to no exceedances in samples from the Rio Grande aquifer system.

Four of the more than 200 human-related organic compounds analyzed - the fumigant dibromochloropropane (DBCP), the insecticide dieldrin, and the solvents perchloroethene (PCE) and trichloroethene (TCE) - were measured at concentrations greater than humanhealth benchmarks in Southwest domestic and public-supply wells. All of the exceedances for these compounds except one were in samples from the Central Valley aquifer system and California Coastal Basin aquifers. An increased risk of cancer is associated with long-term exposure to water with DBCP, dieldrin, PCE, and TCE at concentrations above human-health benchmarks. At least one VOC, pesticide, or pesticide degradate was measured, mostly at low concentrations, in 57 percent of samples from drinking-water wells. The occurrence of these human-related organic compounds at low concentrations in groundwater is of concern because it indicates that many basin-fill aquifers in the Southwest are vulnerable to contamination from human activities and have the potential to be affected by higher concentrations of these humanrelated contaminants in the future.

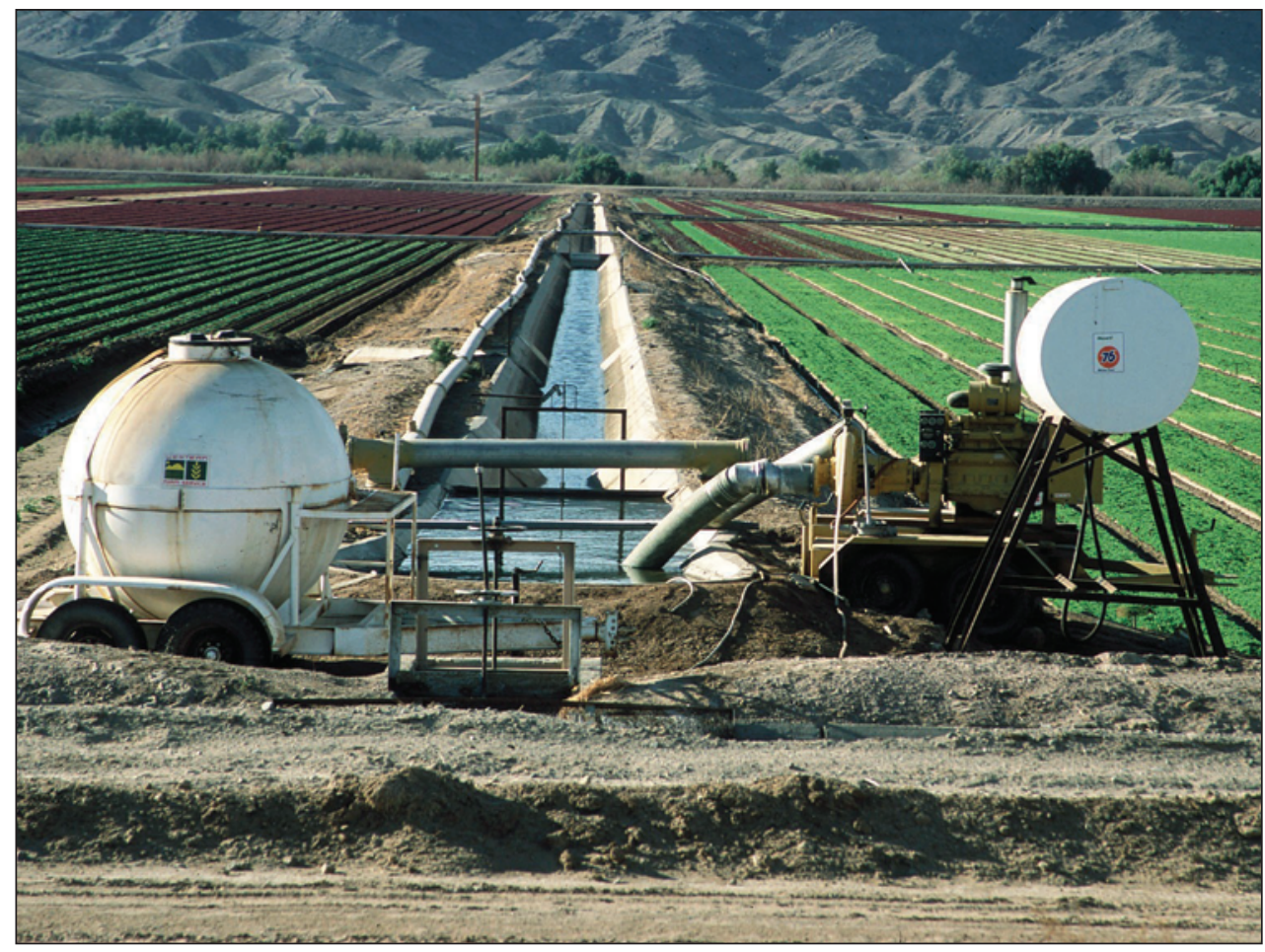

At least one VOC or pesticide compound was measured, mostly at low concentrations, in 57 percent of samples from drinking-water wells.
Fertilizers, a potential source of nitrate to groundwater, are used to maximize crop yield in the Southwest. Here, fertilizer is added to irrigation water in Yuma, Arizona. 


\section{Secondary Standards for Drinking Water and Guidelines for Irrigation Water}

The USEPA has established Secondary Maximum Contaminant Levels (SMCLs) (rather than MCLs) for several "nuisance" constituents that, at elevated concentrations, can make water look, smell, or taste unpleasant, stain plumbing, or cause other undesirable effects (table 5-2). These secondary drinking-water standards are designed to help public suppliers provide water that is acceptable to consumers, and adherence to them is voluntary (see sidebar, Human-health benchmarks and other guidelines used in this assessment, p. 43).

Dissolved solids in water are primarily made up of the major ions calcium, sodium, bicarbonate, sulfate, and chloride. The SMCL for dissolved solids is $500 \mathrm{mg} / \mathrm{L}$ and is designated to avoid a salty taste, color, staining, or greater costs because of mineral deposits in plumbing for consumers of public water supplies.(23) Dissolved-solids concentrations were greater than the SMCL in 26 percent of Southwest drinking-water wells, ranging from 32 percent of samples from Basin and Range basin-fill aquifers to 19 percent of samples from California Coastal Basin aquifers and the Rio Grande aquifer system.

Dissolved-solids concentration is a measure of salinity - the salinity of irrigation water can adversely affect crop yield because elevated concentrations of salts in water or soil reduce the ability of crops to extract water from the soil. Concentrations between $450-2,000 \mathrm{mg} / \mathrm{L}$ in irrigation water can cause slight to moderate restrictions in its use on crops, and concentrations greater than $2,000 \mathrm{mg} / \mathrm{L}$ can severely limit use.(24) Eleven percent of samples from 45 irrigation wells had a dissolved-solids concentration greater than $2,000 \mathrm{mg} / \mathrm{L}$ compared to 7 percent of samples from all 1,079 wells assessed in NAWQA Program studies in the Southwest.

\section{Perchlorate: An emerging contaminant of concern in Southwest groundwater}

Perchlorate is a chemical that contains chlorine and oxygen. Perchlorate occurs naturally in arid regions where it can accumulate in the unsaturated zone as a result of atmospheric deposition and evaporative concentration.(64) It also is contained in some nitrate deposits in Chile that are mined and exported for use in the United States as fertilizer. A strong oxidizer, perchlorate is manufactured to produce rocket fuel, fireworks, and explosives. Perchlorate is highly soluble, mobile, and persistent in groundwater.(65) In humans, perchlorate interferes with iodide uptake into the thyroid gland and has a human-health benchmark of $15 \mu \mathrm{g} / \mathrm{L}$ because of its potential adverse effect on pregnant women. Under natural conditions, the probability of perchlorate concentrations greater than $1 \mu \mathrm{g} / \mathrm{L}$ in deep groundwater in the Southwest is unlikely. (66) Predicted concentrations greater than $1 \mu \mathrm{g} / \mathrm{L}$ typically are influenced by human-related sources or excess irrigation water that transports naturally deposited perchlorate to the aquifer. For example, perchlorate concentrations in groundwater are elevated in several areas in California and near Las Vegas, Nevada, where the chemical is associated with industries that manufacture, use, or store rocket fuel.(67)

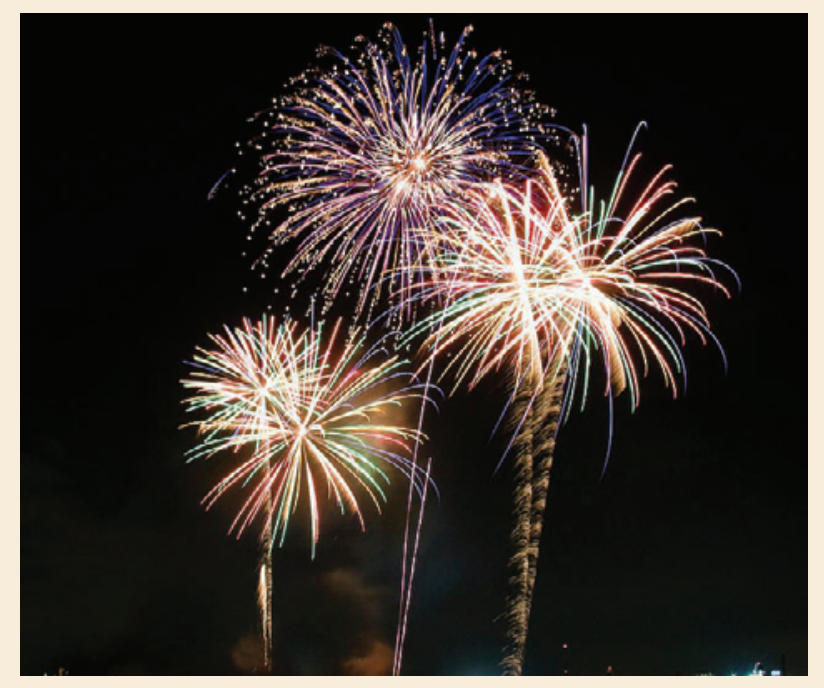

Table 5-2. Secondary Maximum Contaminant Levels (SMCLs) in drinking water are recommended for some constituents.

[mg/L, milligrams per liter; $\mu \mathrm{g} / \mathrm{L}$, micrograms per liter]

\begin{tabular}{|c|c|c|c|c|c|c|}
\hline \multirow{2}{*}{ Constituent } & \multirow{2}{*}{$\begin{array}{c}\text { Secondary } \\
\text { Maximum } \\
\text { Contaminant } \\
\text { Level }\end{array}$} & \multicolumn{5}{|c|}{ Percentage of samples with concentrations that exceeded the Secondary Maximum Contaminant Level } \\
\hline & & $\begin{array}{l}\text { All aquifers in Southwest } \\
\text { Principal Aquifers group }\end{array}$ & $\begin{array}{l}\text { Basin and Range } \\
\text { basin-fill aquifers }\end{array}$ & $\begin{array}{l}\text { Central Valley } \\
\text { aquifer system }\end{array}$ & $\begin{array}{l}\text { California Coastal } \\
\text { Basin aquifers }\end{array}$ & $\begin{array}{c}\text { Rio Grande } \\
\text { aquifer system }\end{array}$ \\
\hline Dissolved solids & $500 \mathrm{mg} / \mathrm{L}$ & 26 & 32 & 25 & 19 & 19 \\
\hline Manganese & $50 \mu \mathrm{g} / \mathrm{L}$ & 8.3 & 3.0 & 8.5 & 15 & 15 \\
\hline Chloride & $250 \mathrm{mg} / \mathrm{L}$ & 5.3 & 10 & 1.3 & 1.8 & 3.0 \\
\hline Sulfate & $250 \mathrm{mg} / \mathrm{L}$ & 5.1 & 7.8 & 2.0 & 1.8 & 9.0 \\
\hline Fluoride & $2 \mathrm{mg} / \mathrm{L}$ & 3.7 & 7.8 & 0.7 & 0 & 3.0 \\
\hline Iron & $300 \mu \mathrm{g} / \mathrm{L}$ & 3.7 & 1.7 & 2.6 & 10 & 3.0 \\
\hline
\end{tabular}




\section{Constituents of Concern in Southwest Principal Aquifers- A National Context}

Concentrations of arsenic, nitrate, uranium, and DBCP exceeded human-health benchmarks about two to six times more frequently in drinking-water wells sampled in Southwest basin-fill aquifers than in Principal Aquifers nationwide (fig. 5-2). Nitrate concentrations were greater than the MCL in 11 percent of Southwest drinking-water wells compared to 5 percent of drinking-water wells nationwide. Dissolved-solids concentrations exceeded the SMCL in 26 percent of Southwest drinking-water wells compared to 16 percent nationwide. The environmental and hydrogeologic settings of the region have a large influence on the concentrations of these contaminants (see chapters 4 and 6). In contrast, concentrations of manganese and radon exceeded human-health benchmarks (the higher proposed MCL for radon) less frequently in samples from Southwest drinking-water wells than in samples nationwide. Water-quality data from the Southwest basin-fill aquifers in a national context are available in appendix 3.

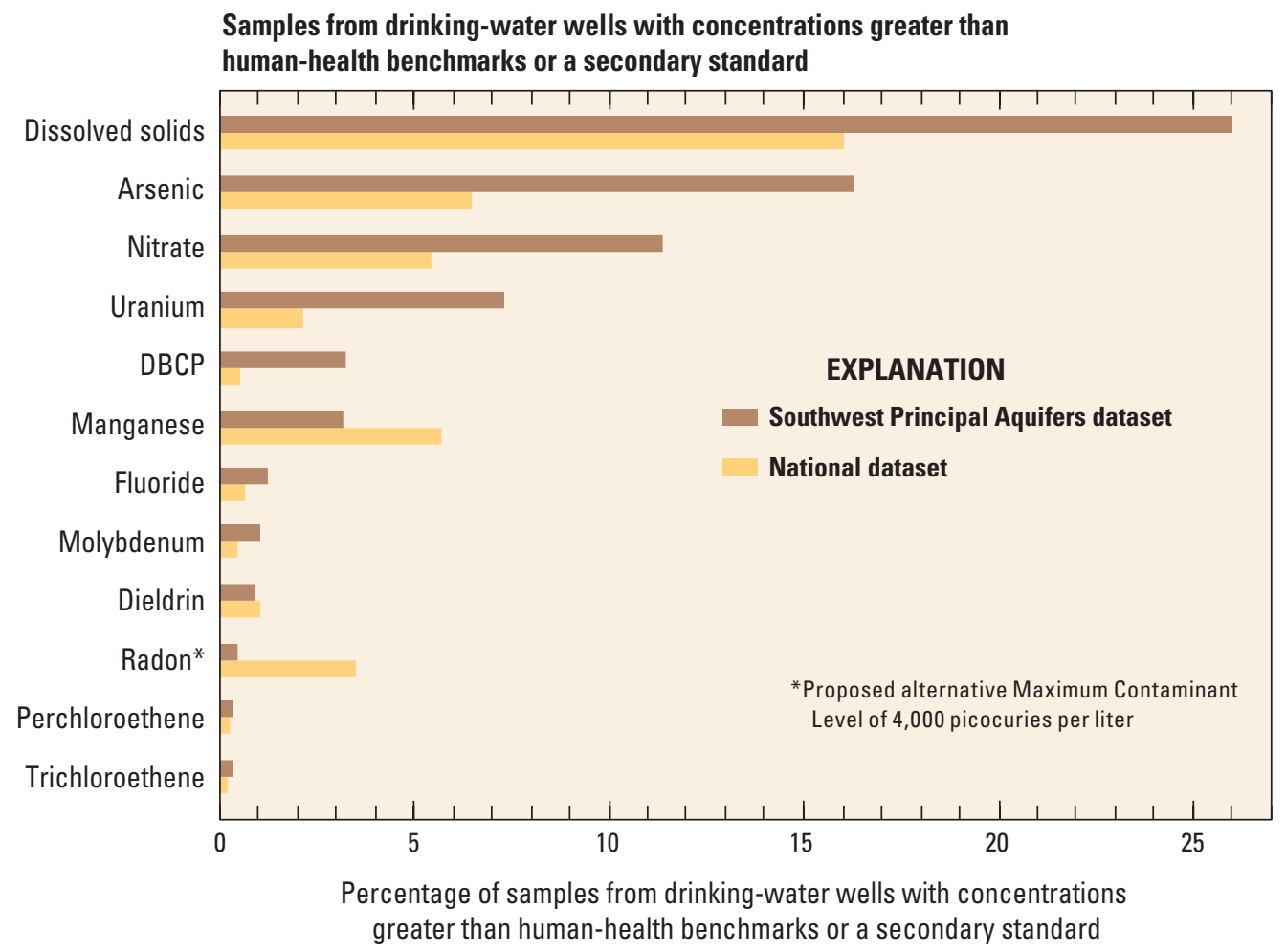

Figure 5-2. Concentrations of arsenic, nitrate, uranium, and dibromochloropropane (DBCP) exceeded human-health benchmarks about two to six times more frequently in drinking-water wells in Southwest basin-fill aquifers than in drinking-water wells in Principal Aquifers nationwide. 


\section{Shallow Groundwater Quality Affects Future Drinking-Water Resources}

Monitoring wells installed in urban and agricultural areas are used to sample groundwater that is shallower and younger than water pumped from domestic and public-supply wells. Several contaminants of concern in deeper groundwater used for drinking water also exceeded human-health benchmarks in shallow monitoring wells (fig. 5-3). Artificial recharge and pumping can cause shallow groundwater and any contaminants it contains to move further down into the aquifer. This applies to the human-related contaminants nitrate, DBCP, and dieldrin that are used at land surface, but constituents with geologic sources-arsenic and uranium - can be present naturally at elevated concentrations at greater aquifer depths. Surprisingly, uranium concentrations in the Central Valley aquifer system exceeded the MCL in one in five shallow monitoring wells in agricultural areas and one in four domestic wells, with evidence that elevated concentrations are moving deeper into the aquifer system. See chapter 6 for more information on the processes that affect the movement of uranium - and other constituents - from shallow groundwater affected by human activities and processes at the land surface to deeper groundwater used for drinking-water supply.

Samples with concentrations greater than human-health benchmarks

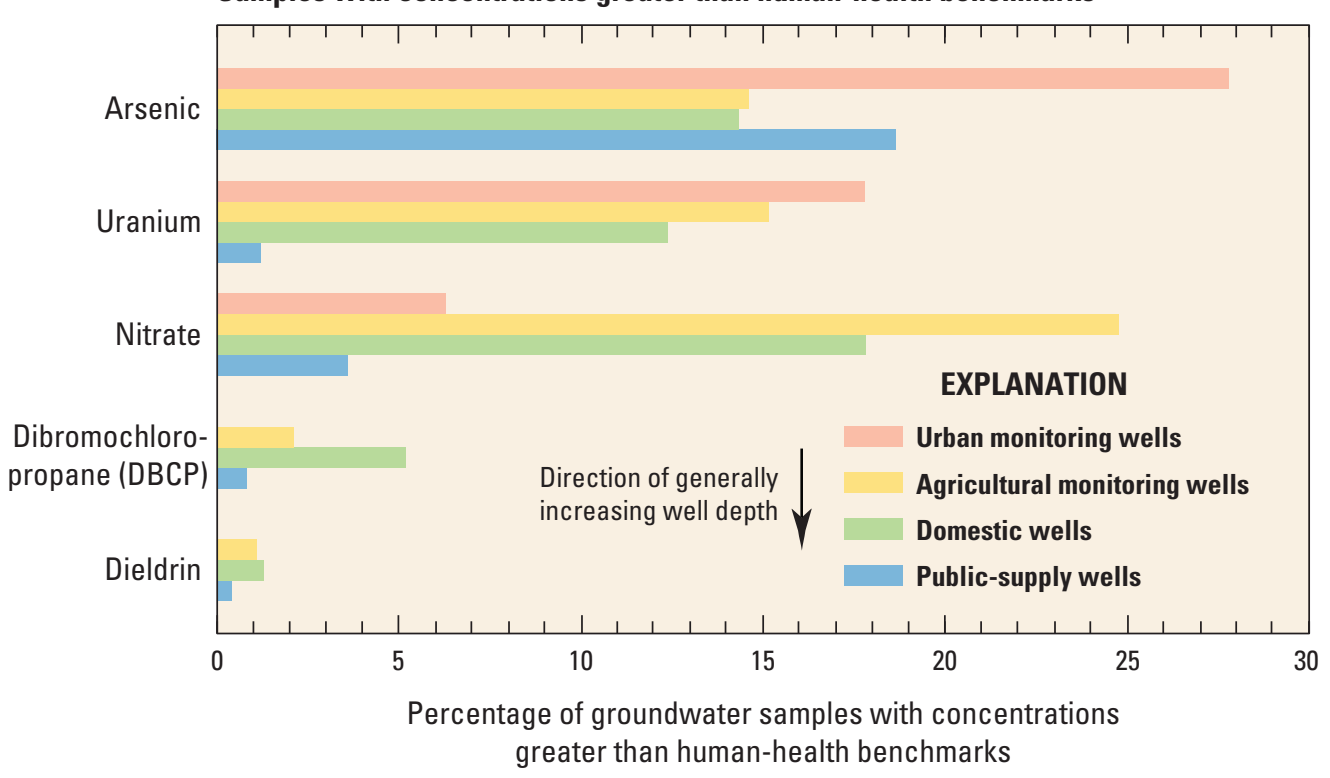

Figure 5-3. Concentrations of several constituents in shallow groundwater and in water from deeper, drinking-water wells exceeded human-health benchmarks. The human-related contaminants nitrate, dibromochloropropane, and dieldrin are or were used at land surface and have moved deeper into basin-fill aquifers. For example, nitrate exceeded its Maximum Contaminant Level in almost 25 percent of shallow monitoring wells in agricultural areas across the Southwest compared to 18 percent from domestic wells and 4 percent from public-supply wells. 


\section{Chapter 6: Understanding Where and Why Contaminants Occur in Southwest Basin-Fill Aquifers}

A rsenic, uranium, nitrate, dissolved solids, VOCs, and pesticides - these are the contaminants that are most likely to limit the use of groundwater now or in the future. Where do they occur, and what sources or processes control their concentrations? Answering these questions for selected basin-fill aquifers can help to identify areas across the Southwest that might be especially vulnerable to contamination and to estimate concentrations in areas where no data are available.

The heavily irrigated Coachella Valley in southern California extends to the Salton Sea, a topographically low area that naturally accumulates minerals in groundwater through evapotranspiration.
This chapter describes the sources of and factors that affect arsenic, uranium, nitrate, dissolved solids, VOCs, and pesticides in Southwest basin-fill aquifers, with focus on the intermediate to deeper parts of the aquifers that supply water for drinking and irrigation purposes. 


\section{A. Geologic sources and natural factors that affect groundwater quality}

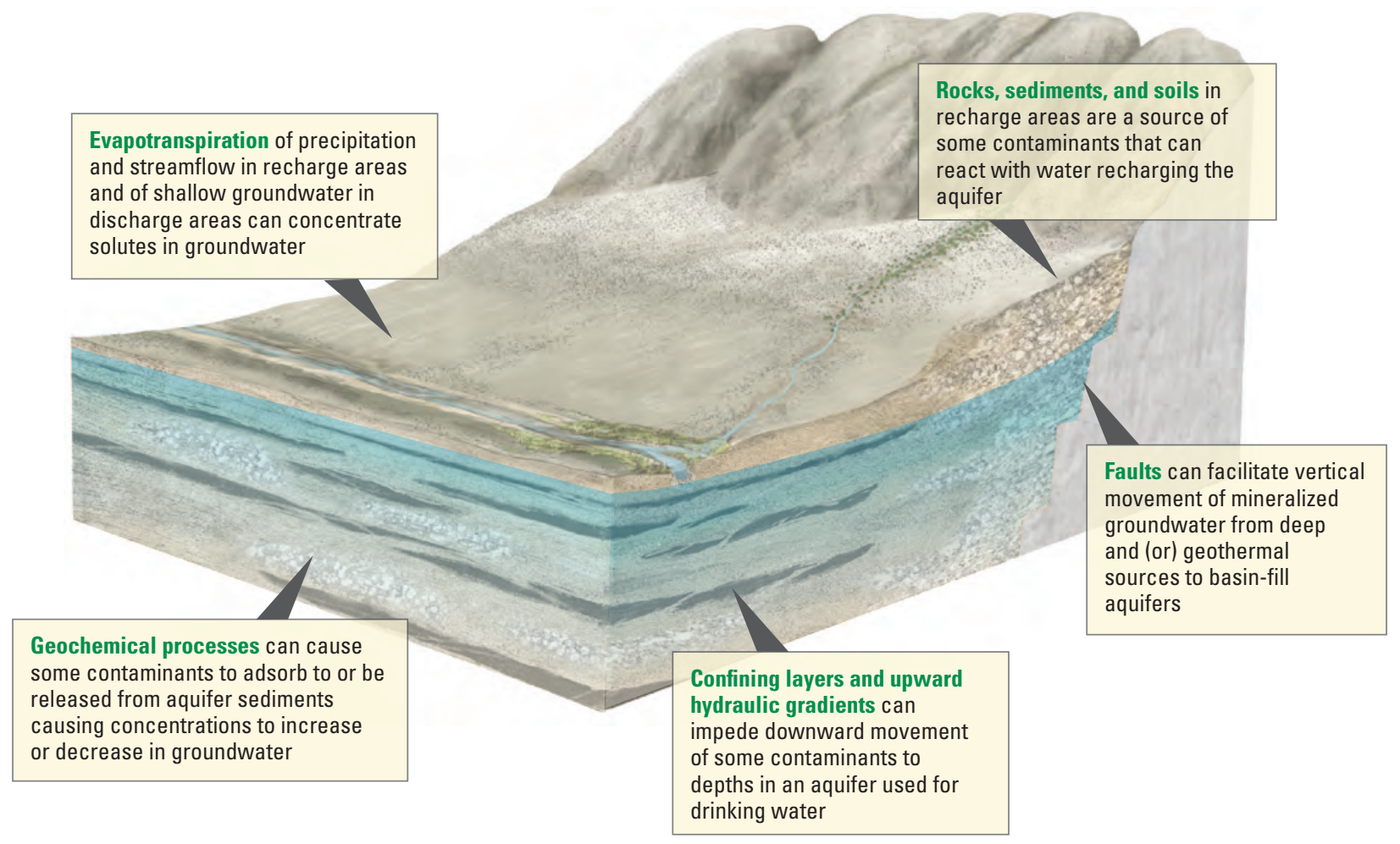

\section{B. Human-related sources and factors that affect groundwater quality}

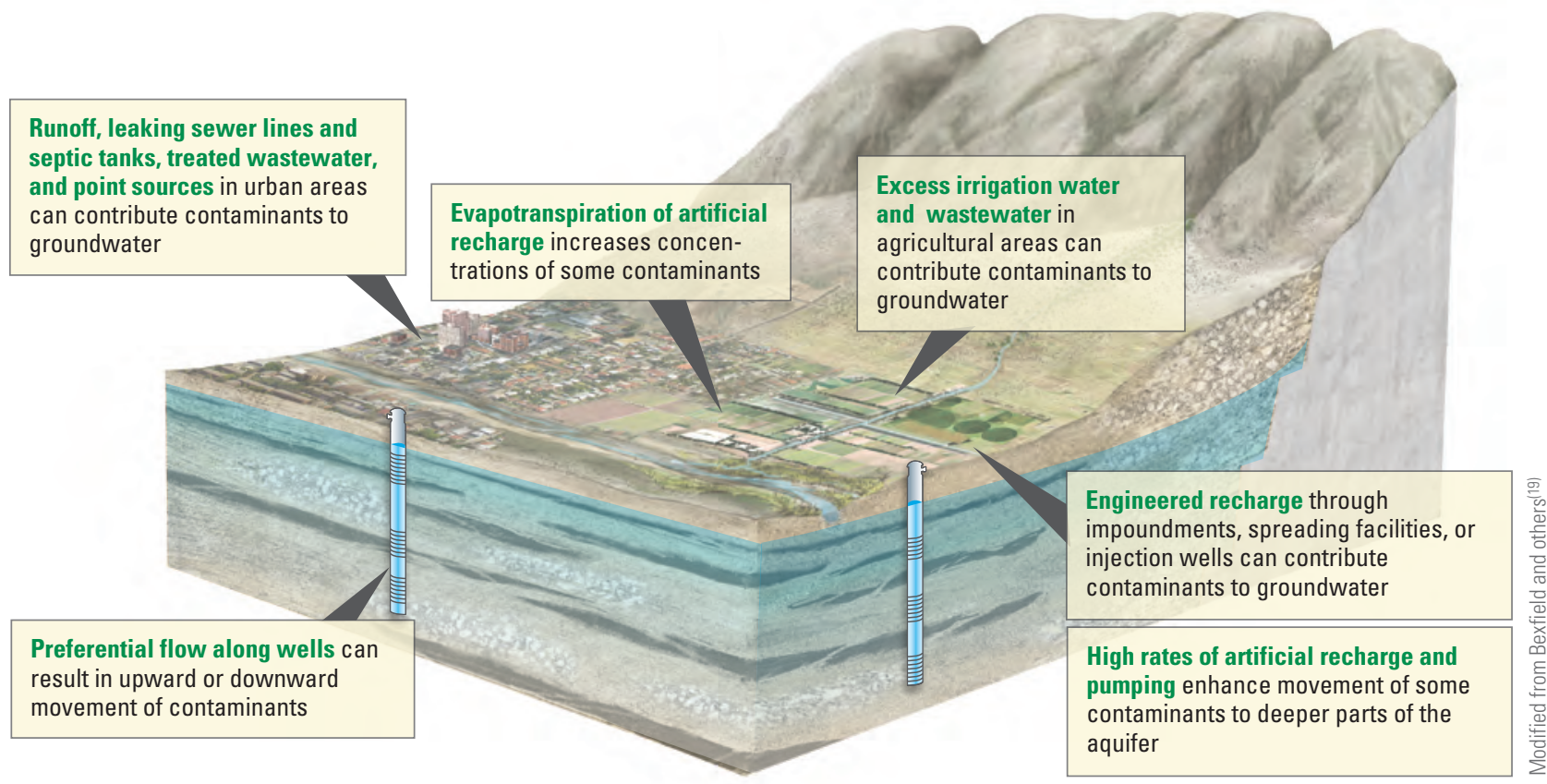

Figure 6-1. Several common geologic and human-related sources and factors influence water quality in Southwest basin-fill aquifers. $A$, Geologic sources and natural processes can result in high concentrations of constituents in groundwater. For example, evapotranspiration can increase concentrations of arsenic, uranium, nitrate, and dissolved solids in groundwater. $B$, Urban and agricultural activities can release nitrate, dissolved solids, volatile organic compounds, and pesticides to groundwater and move them to greater depths in an aquifer. 
Almost one-half of water samples from publicsupply wells and onequarter from domestic wells sampled as part of studies in the Rio Grande aquifer system contained arsenic at a concentration that exceeded the Maximum Contaminant Level.

\section{Arsenic}

Some geochemical conditions can cause arsenic in basin-fill sediments to dissolve into groundwater. As a result, groundwater in Southwest basin-fill aquifers commonly has arsenic concentrations that exceed the MCL of $10 \mu \mathrm{g} / \mathrm{L}$. Many factors affect arsenic concentrations in groundwater-source rock type, geochemical conditions, the amount of time that groundwater is in contact with arsenic-containing rocks and sediment, the amount of groundwater moving through the aquifer, and evaporative concentration.

Arsenic is a nonmetallic trace element that commonly is present in rocks in the Southwest. Drinking water is the primary means by which people are exposed to arsenic, and long-term exposure is associated with many illnesses including skin, bladder, and lung cancers; immunological impairments; and cardiovascular disease. In 2001, the USEPA lowered the MCL for arsenic in drinking water from 50 to $10 \mu \mathrm{g} / \mathrm{L}$.(25) Groundwater used for public supply in areas where the MCL is exceeded must be treated or mixed with water that contains lower arsenic concentrations to bring levels below the drinking-water standard. Many public suppliers have installed costly facilities to treat contaminated groundwater (see sidebar, The cost of arsenic contamination, p. 54).

Much of the information presented in this section is from the report "Predicted nitrate and arsenic concentrations in basinfill aquifers of the southwestern United States" (available at http://pubs.usgs.gov/sir/2012/5065/).

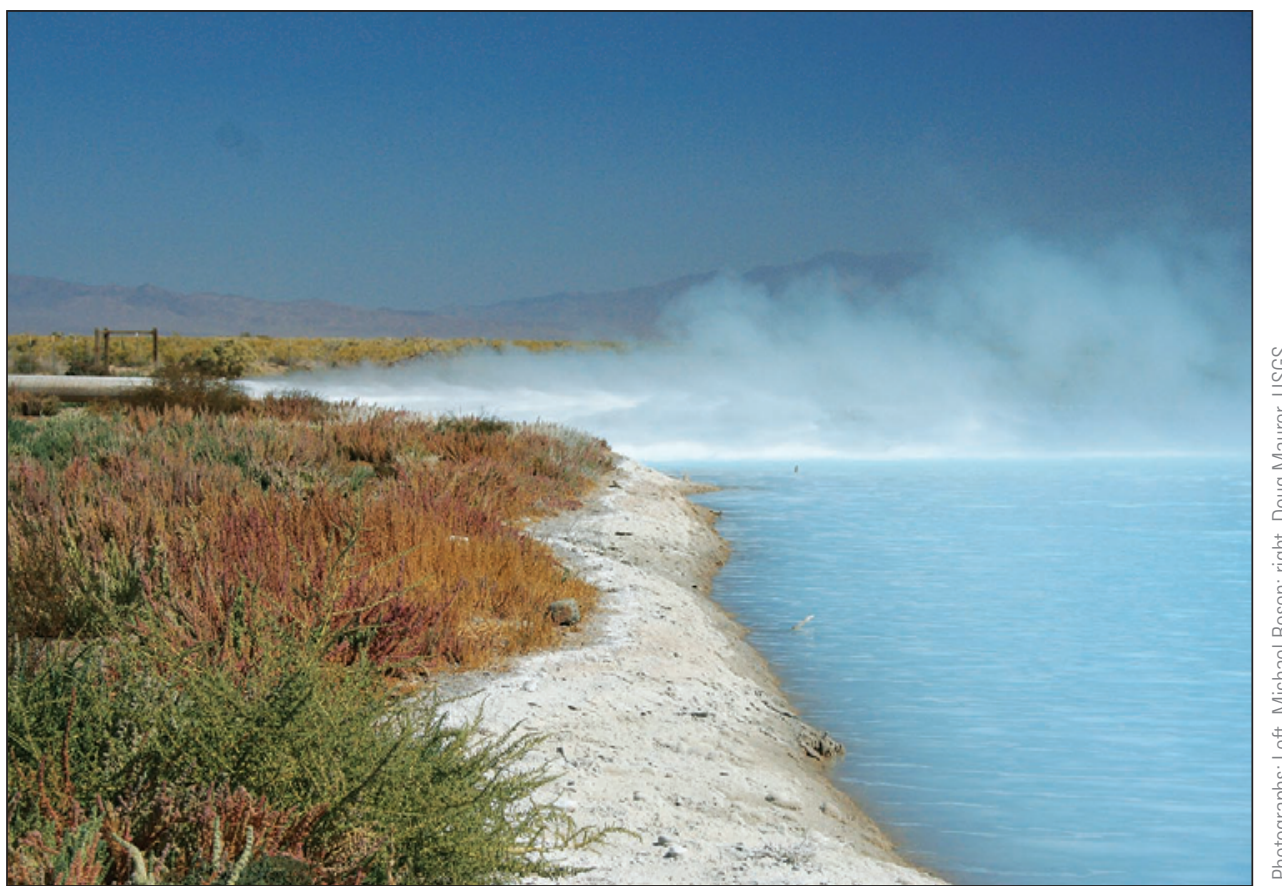

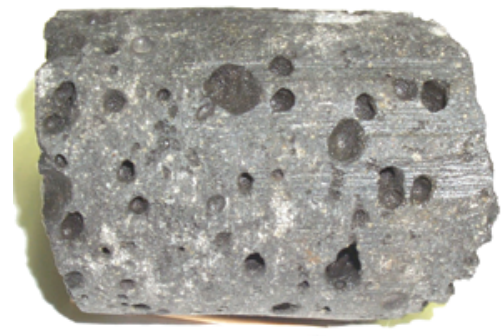

Arsenic occurs throughout the Southwest from geologic sources such as volcanic rocks (basalt, left) and geothermal water (discharge from a geothermal powerplant in Dixie Valley, Nevada, right). 
Arsenic concentrations exceeded the MCL in about 16 percent of drinking-water wells sampled as part of studies of the Southwest Principal Aquifers (table 5-1). The MCL for arsenic was more frequently exceeded in domestic and public-supply wells in the Rio Grande aquifer system and Basin and Range basin-fill aquifers than in the Central Valley aquifer system or California Coastal Basin aquifers (table 6-1). Samples from almost one-half of the public-supply wells and one-quarter of domestic wells in the Rio Grande aquifer system exceeded the MCL for arsenic. Elevated concentrations - two or more times higher than the MCL - were measured in shallow groundwater sampled from monitoring wells, in addition to deeper groundwater sampled from drinking-water wells in the Southwest (fig. 6-2). Overall, arsenic concentrations exceeded the MCL in 19 percent of the 1,018 wells sampled as part of the NAWQA Program studies in the Southwest. This amount is consistent with a larger USGS dataset for the region (fig. 6-3) that was used to simulate arsenic concentrations.

Table 6-1. Percentage of samples with an arsenic concentration that exceeded the MCL of $10 \mu \mathrm{g} / \mathrm{L}$. See appendix 2, table A2-2, for the number of wells sampled.

\begin{tabular}{|c|c|c|c|c|c|}
\hline Type of well & $\begin{array}{c}\text { All aquifers } \\
\text { in Southwest } \\
\text { Principal Aquifers } \\
\text { group }\end{array}$ & $\begin{array}{c}\text { Basin and Range } \\
\text { basin-fill } \\
\text { aquifers }\end{array}$ & $\begin{array}{l}\text { Central Valley } \\
\text { aquifer system }\end{array}$ & $\begin{array}{l}\text { California Coastal } \\
\text { Basin aquifers }\end{array}$ & $\begin{array}{c}\text { Rio Grande } \\
\text { aquifer system }\end{array}$ \\
\hline Agricultural land-use monitoring wells & 15 & 51 & 10 & Not sampled & 3.3 \\
\hline Domestic wells & 14 & 21 & 8.1 & 0 & 24 \\
\hline All sampled wells & 19 & 30 & 8.8 & 6.3 & 17 \\
\hline
\end{tabular}

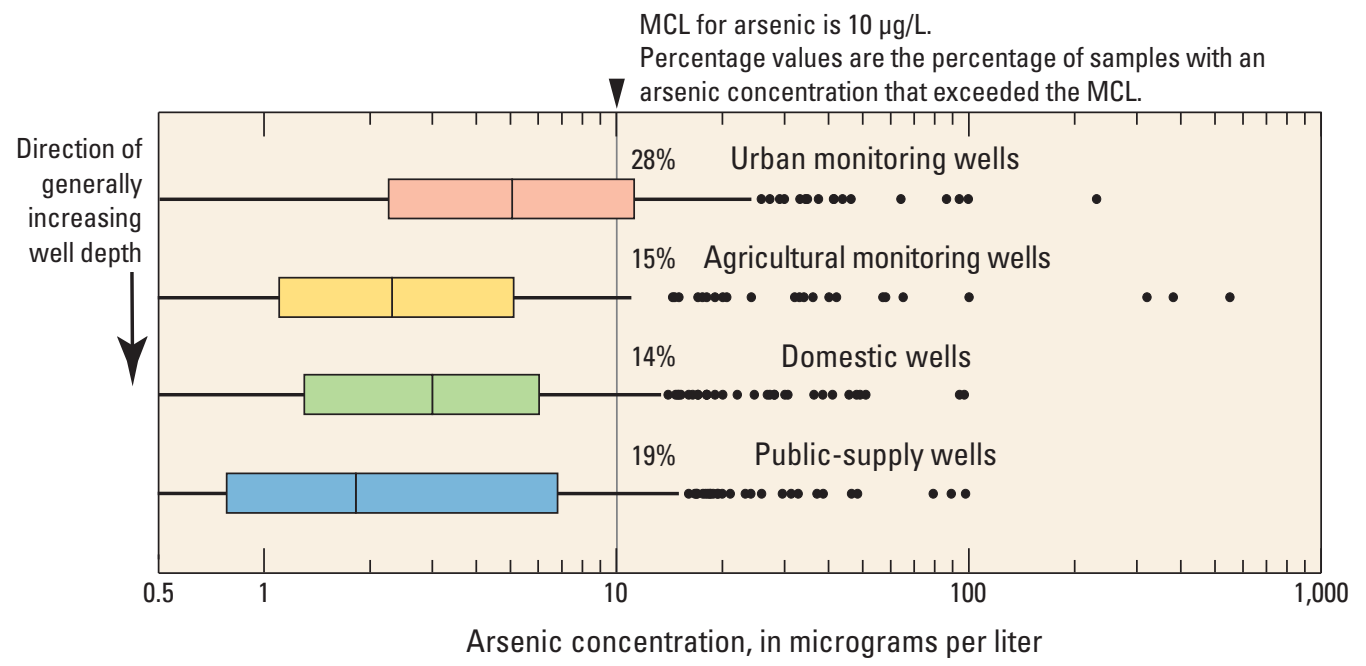

See sidebar, Boxplots, p. 53

Figure 6-2. Arsenic concentrations in wells ranged from less than 1 to more than $100 \mu \mathrm{g} / \mathrm{L}$. Although median concentrations in the monitoring, domestic, and public-supply wells were less than the Maximum Contaminant Level (MCL), many samples had concentrations up to 10 times higher than the MCL. 


\section{Boxplots}

Boxplots are used to illustrate how results are distributed within a group. The "box" ranges from the 25th to the 75th percentile and represents 50 percent of the data. The horizontal line in the middle of the box is the median value-one-half of the values in the group are greater than the median and one-half are less.

Percentiles describe the percentage of values in a group that are less than the given value: 25 percent of the values in a group are less than the 25 th percentile; 75 percent of the values in a group are less than the 75th percentile. The median is also the 50th percentile.

If, for example, the 75th percentile for the measured concentration of a contaminant in a group of wells is equal to the human-health benchmark for that contaminant, then 75 percent, or three-fourths, of the wells have a concentration of that contaminant less than the benchmark, and 25 percent, or one-fourth, have a concentration greater than the benchmark.

The "whiskers" (vertical lines) in these figures extend to the 10th and 90th percentiles; box and whiskers together represent 80 percent of the data. Values greater than the 90th or less than the 10th percentile are shown as individual points (outliers).

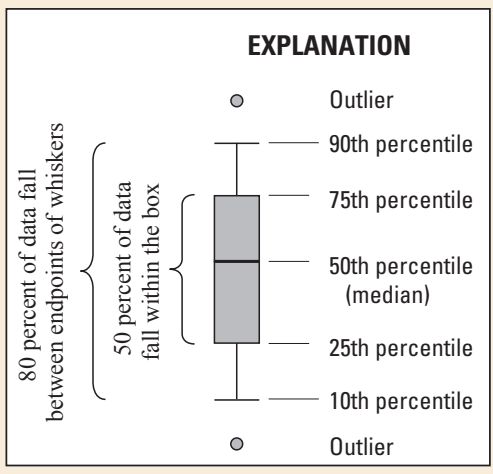

\section{Measured arsenic concentration in basin-fill aquifers}

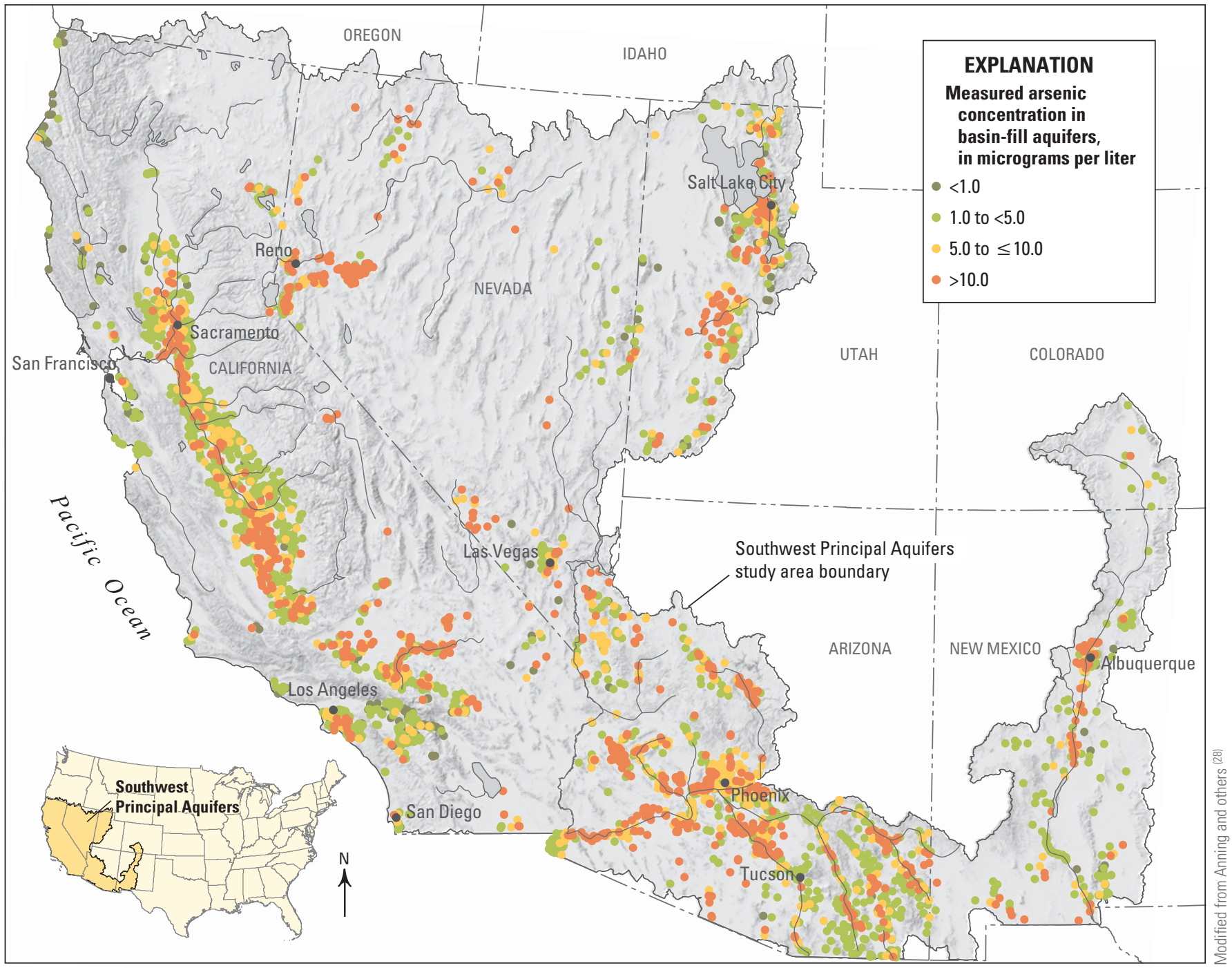

Figure 6-3. During 1980-2009, USGS studies in the Southwest were conducted to measure arsenic in a total of 4,162 wells that tap basin-fill aquifers. About 19 percent of arsenic concentrations in these wells were greater than the $\mathrm{MCL}$ of $10 \mu \mathrm{g} / \mathrm{L}$, consistent with data from this study (table 6-1). There are few or no arsenic data for groundwater in large areas in the Southwest, mostly because there are few people in these areas and, therefore, few wells. 


\section{The cost of arsenic contamination}

The USEPA estimated in 2001 that the annual cost to reduce arsenic concentrations to below the MCL would range from $\$ 0.86$ to $\$ 32$ per household for customers of large public water systems (more than 10,000 people) to $\$ 165$ to $\$ 327$ per household for very small systems (25-500 people).(25) Water supplies in the Southwest are limited and often naturally contain arsenic concentrations high enough to require treatment. According to fiscal year 2010 statistics, (68) 274 public water systems in California, Nevada, Utah, Arizona, and New Mexico-mostly small systems that lack a large customer base to pay for water treatment-had a water source containing arsenic concentrations that exceeded the MCL for arsenic.

In Fallon, Nevada, groundwater supplying about 8,400 residents and a nearby Naval Air Station consistently contains arsenic concentrations exceeding the MCL. In 2004 a treatment facility was installed for arsenic removal at a cost of $\$ 19$ million.(69) Upgrades to water systems throughout Nevada to remove arsenic have been estimated to cost many millions of dollars. ${ }^{(70)}$

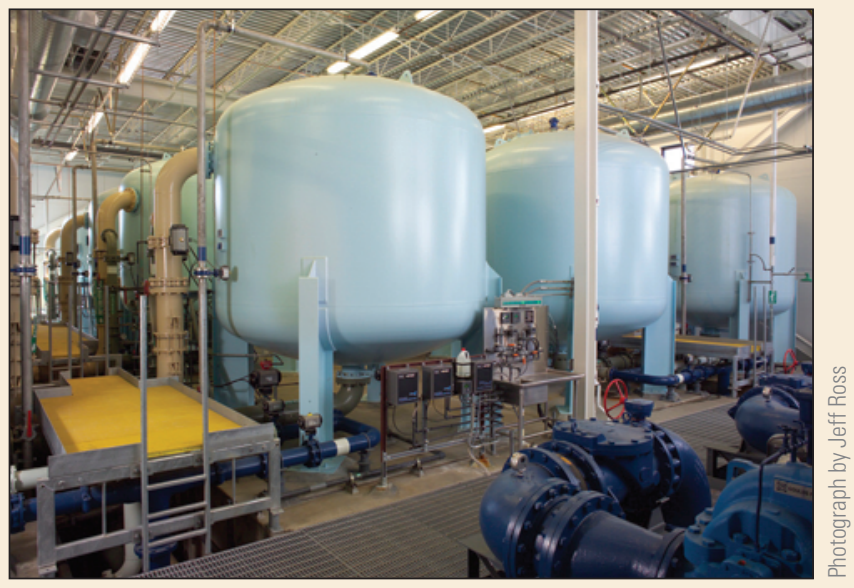

The arsenic treatment system for Fallon, Nevada, adds dissolved iron to the water. The iron reacts with the dissolved arsenic to form particles that then are filtered out of the water.
Volcanic rocks, an arid to semiarid climate, and closed or constricted basins contribute to elevated concentrations of arsenic in Southwest groundwater.

\section{Rock Type, Climate, and Location Within a Basin Affect Arsenic Concentrations in Groundwater}

The Southwest contains many areas with volcanic rocks, an arid to semiarid climate, and closed or constricted basins - all factors that contribute to elevated arsenic concentrations in groundwater. Arsenic commonly is found in Southwest basin-fill aquifers in areas with volcanic and crystalline rocks (see extent of volcanic rocks in figure 3-2), geothermal water, and (or) sulfide minerals associated with these geologic settings.(26) Low precipitation rates and high evapotranspiration rates result in low groundwater recharge rates to many Southwest basins. Arsenic remaining after water evaporates accumulates in aquifers in closed or constricted basins with low recharge rates. In contrast, basins with higher recharge rates have more groundwater to flush arsenic from the aquifer.

Arsenic concentrations increase as groundwater moves from recharge areas near mountain fronts through arsenic-bearing sediment in the basin toward discharge areas in the basin lowlands.(27) The long flow paths typical of Southwest aquifers contribute to elevated arsenic concentrations measured in basin lowlands because the water is in contact with the aquifer sediment for long periods of time, allowing important geochemical reactions to occur. The area where groundwater is located along a flow path in a basin can be used to infer groundwater age and geochemical conditions, which influence concentrations of dissolved arsenic and other constituents with geologic sources in an aquifer. In general, as groundwater moves along a flow path, $\mathrm{pH}$ increases and the concentration of dissolved oxygen decreases.

The interaction of arsenic with metal oxides, particularly iron oxide, is one of the most important processes by which groundwater can become enriched or depleted in arsenic. When geochemical conditions favor arsenic release (desorption) from oxide surfaces, groundwater concentrations are higher than when geochemical conditions favor arsenic attachment (adsorption) to oxide surfaces. Adsorption and desorption of arsenic are controlled largely by the concentration of dissolved oxygen in groundwater and by $\mathrm{pH}$. Generally, if the $\mathrm{pH}$ of the groundwater is less than 8 , arsenic adsorbs to iron oxides, removing it from groundwater (fig. 6-4). If the $\mathrm{pH}$ is greater than 8 , arsenic tends to desorb from the iron oxides and dissolves into the groundwater. Under anoxic conditions, iron oxides dissolve and release iron and arsenic into the groundwater regardless of $\mathrm{pH}$. 


\section{Arsenic concentrations in groundwater}

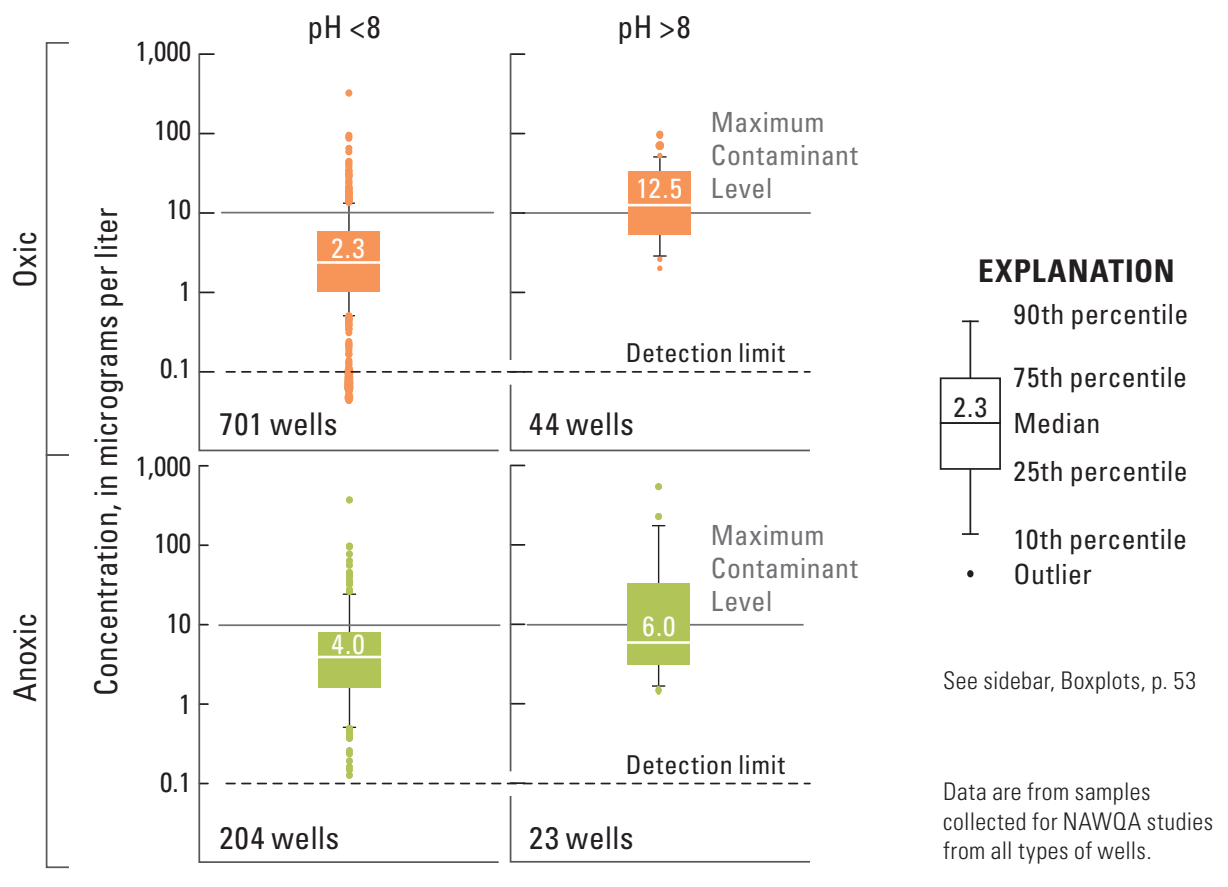

Figure 6-4. More arsenic typically is dissolved in groundwater from Southwest basin-fill aquifers under oxic conditions at a pH greater than 8 than under anoxic conditions at a $\mathrm{pH}$ less than 8 . The $\mathrm{pH}$ and redox condition of the groundwater affect whether arsenic adsorbs to iron oxides on the aquifer sediment or is released into groundwater.
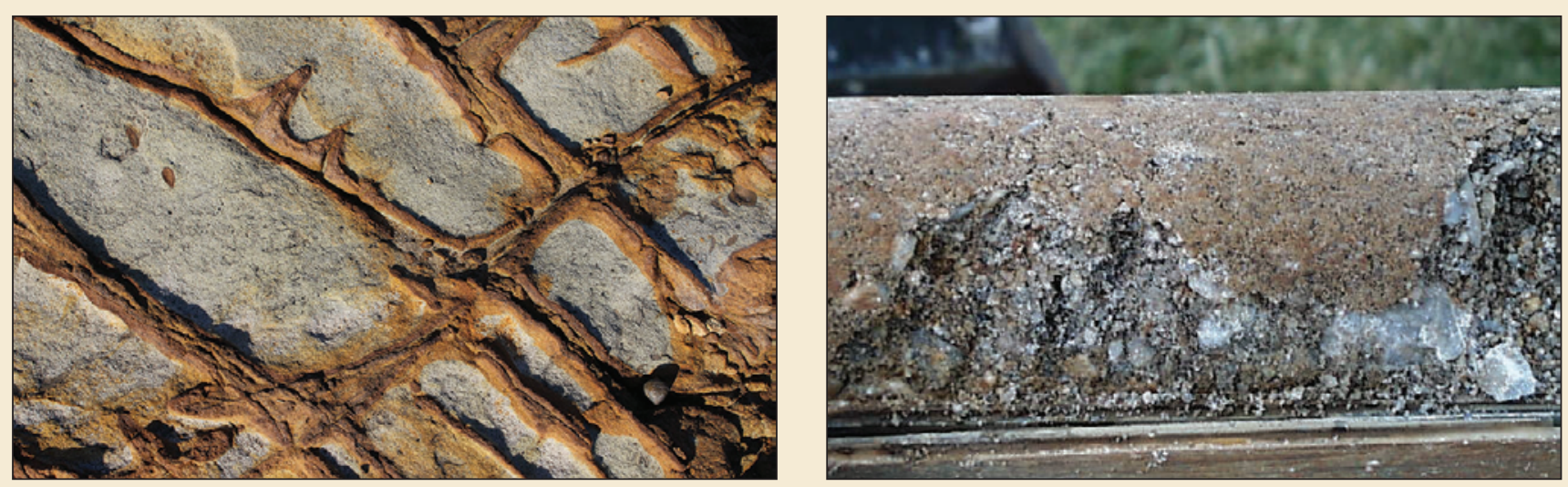

Photographs: Left, Michael Rosen; right, Susan Thiros, USGS

Arsenic can attach to iron oxide (reddish-brown color visible in photographs) that is present in cracks in rocks (left) and that coats basin-fill sediment (right). The $\mathrm{pH}$ and redox conditions in an aquifer determine if the arsenic remains attached to the iron oxide or dissolves into the groundwater. Recharged oxygenated irrigation water and groundwater pumping commonly cause the water table to fluctuate, which can release arsenic from basin-fill sediment into the groundwater.(32) 


\section{The Middle Rio Grande Basin-An example of the influence of geology, water source, and geochemical conditions on arsenic concentrations in groundwater}

Arsenic concentrations greater than $20 \mu \mathrm{g} / \mathrm{L}$-twice the current $\mathrm{MCL}$ - have been measured in groundwater throughout the Middle Rio Grande Basin, New Mexico. Groundwater is the main source of drinking water for many communities in the basin. To deliver drinking water that does not contain arsenic concentrations above the MCL, some public water suppliers use arsenic treatment systems, blend high-arsenic groundwater with low-arsenic water, or both. Groundwater was the primary source of drinking water for Albuquerque residents until late 2008 when low groundwater levels caused by pumping prompted the city to import and treat surface water; since that time, groundwater continues to be a secondary source of drinking water.

Arsenic in the Middle Rio Grande Basin originates predominately from one of two geologic sources, depending on the location within the basin:

- Groundwater inflow from the Jemez Mountains to the north. High arsenic concentrations in recharge water from the Jemez Mountains result from contact between water and volcanic rocks rich in arsenic. This source of groundwater recharge affects the aquifer primarily in the northwestern part of the Middle Rio Grande Basin.
- Deep mineralized groundwater. Groundwater circulating at depth in the Middle Rio Grande Basin has high concentrations of arsenic, chloride, and other elements. This deep groundwater comes into contact with shallower groundwater where it flows upward, primarily along fault zones throughout the basin. Evidence of this mixing of shallow and deep groundwater includes locally high dissolved-solids concentrations (exceeding 5,000 mg/L), hot water temperatures (exceeding 125 degrees Fahrenheit $\left[{ }^{\circ} \mathrm{F}\right]$ ), and the occurrence of arsenite (the reduced form of arsenic) in groundwater at relatively shallow depths.

Arsenic concentrations in groundwater from the Middle Rio Grande Basin also are affected by $\mathrm{pH}$-controlled desorption from iron oxides that coat the aquifer sediment. In some areas where the groundwater was oxygenated with a $\mathrm{pH}$ higher than 8.5, arsenic concentrations exceeded $20 \mu \mathrm{g} / \mathrm{L}$. The arsenic dissolved in this groundwater was present primarily as arsenate (the oxidized form of arsenic).

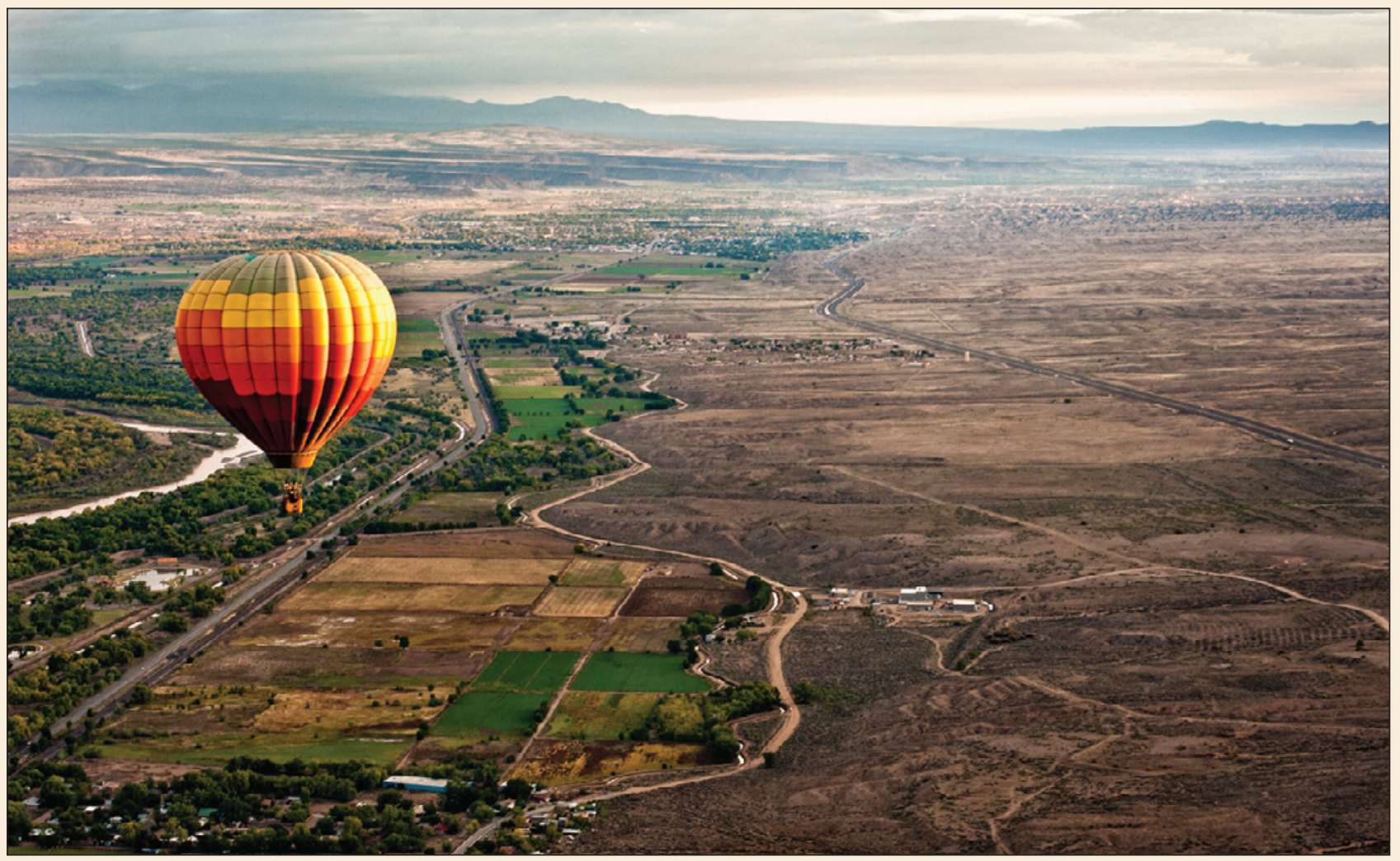

Residents of the Albuquerque area, New Mexico, depend on water from the Rio Grande and from the basin-fill aquifer. Groundwater west and north of the city contains elevated concentrations of arsenic. 
Arsenic concentration in Middle Rio Grande Basin groundwater

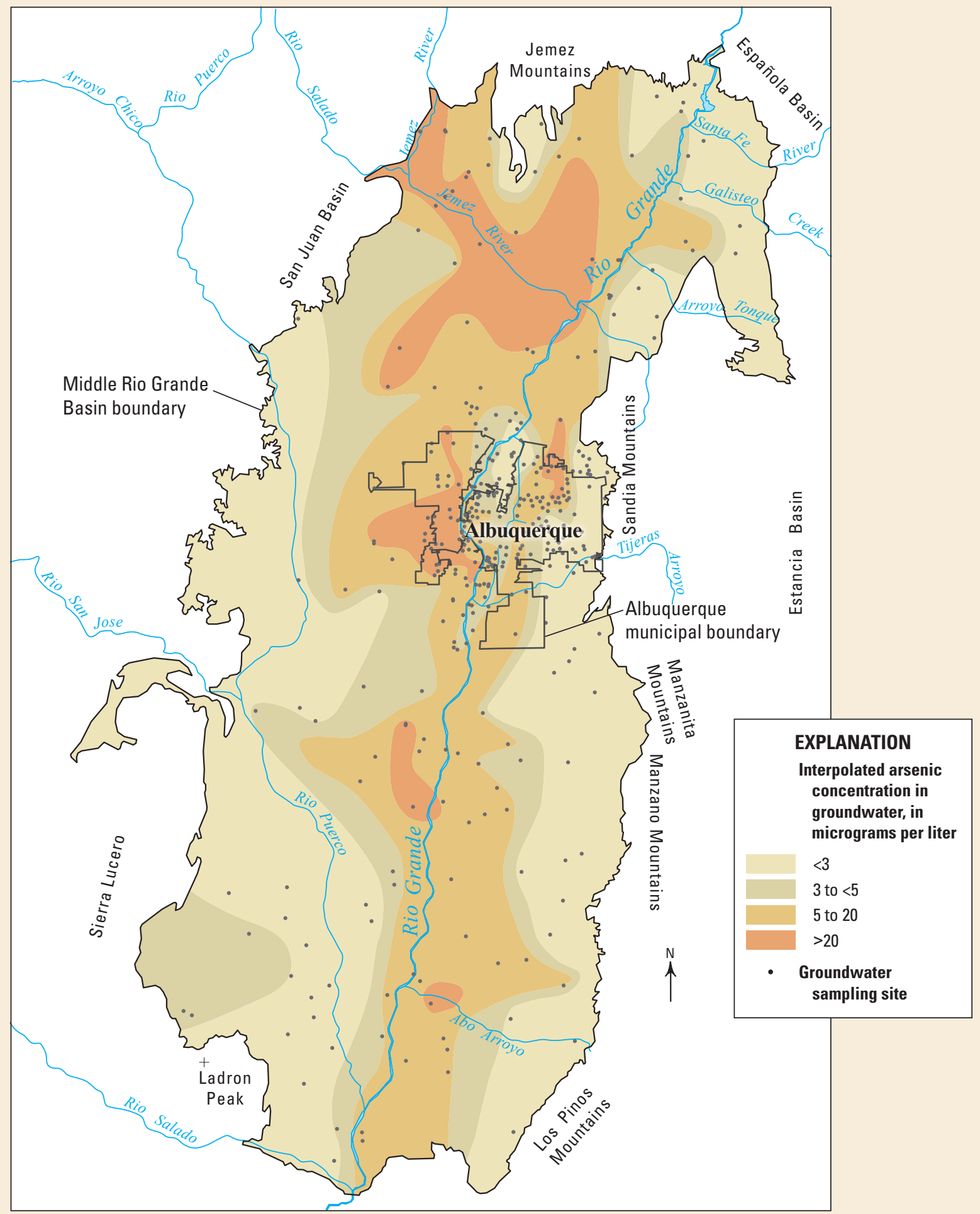

Modified from Plummer and others ${ }^{(78)}$

The highest concentrations of arsenic in groundwater in the Middle Rio Grande Basin are associated with volcanic rocks in the northern part of the basin and with fault zones through which deep, mineralized groundwater rises. Arsenic concentrations in groundwater generally are lower along the eastern and western margins of the basin, where low-arsenic recharge water enters the aquifer, than near the center of the basin, where groundwater has been in contact with arsenic-bearing sediment for a long time. 


\section{Estimating Arsenic Concentrations in Areas Where No Data Are Available}

The relation between arsenic concentrations in groundwater and rock type, climate, and location within a basin (for example, basin lowlands) was explored using a statistical model.(28) The model provides estimates of arsenic concentrations in areas where no measurements are available (fig. 6-3).

The statistical model found that, in a basin surrounded by volcanic and crystalline rocks, arsenic concentrations are greater in areas with less recharge to the aquifer than in areas with more recharge (fig. 6-5). Areas with relatively low groundwater recharge rates tend to have a longer groundwater residence time resulting in less flushing of arsenic and other constituents from the aquifer than areas with higher rates of recharge. As groundwater moves along the flow
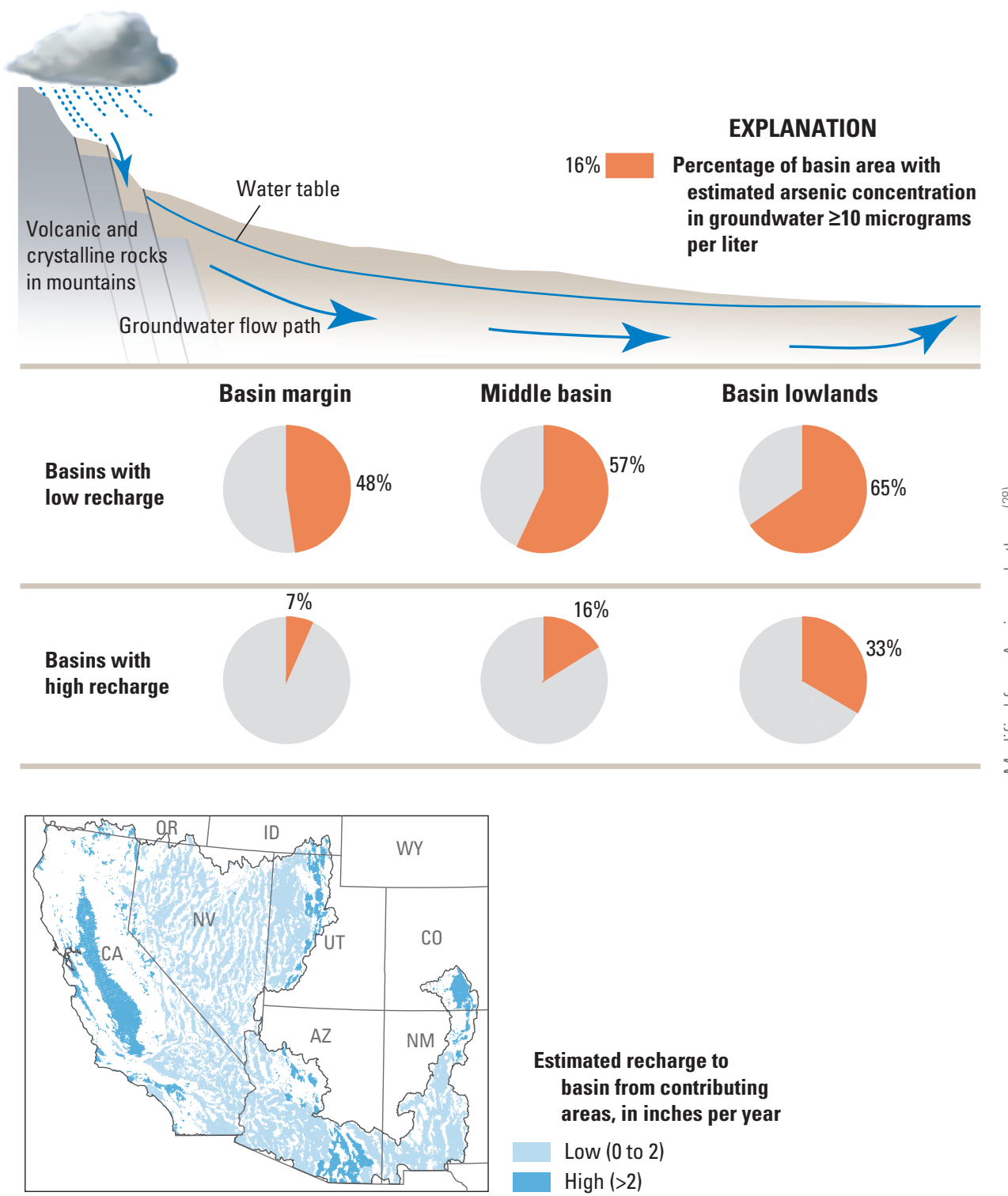

Figure 6-5. Arsenic concentrations in Southwest basins with volcanic and crystalline rocks in the adjacent mountains typically increase with distance along the groundwater flow path because of geochemical reactions between the groundwater and basin-fill sediments derived from the mountains. Aquifers in these areas that have relatively low recharge rates (less than about 2 inches per year) tend to have longer groundwater residence times and higher predicted arsenic concentrations than those that have higher rates of recharge. 
path from recharge areas near basin margins to discharge areas in basin lowlands, arsenic concentrations were likely to increase. Arsenic concentrations greater than the MCL are more likely to occur in basin lowlands than in other parts of the basin because of a longer residence time in the aquifer and geochemical reactions between the groundwater and arsenicbearing sediment.

The model estimates that 43 percent of the area with basin-fill aquifers has arsenic concentrations equal to or greater than $10 \mu \mathrm{g} / \mathrm{L}$ (fig. 6-6). This percentage is higher than might be expected on the basis of measured concentrations because of the inclusion of large areas with arsenic-bearing rocks and constricted groundwater flow. Many of the basins with these conditions are sparsely populated with relatively little groundwater pumping (fig. 4-5) so there are few data on concentrations, primarily because there are so few wells to sample.

\section{Estimated arsenic concentration in basin-fill aquifers}

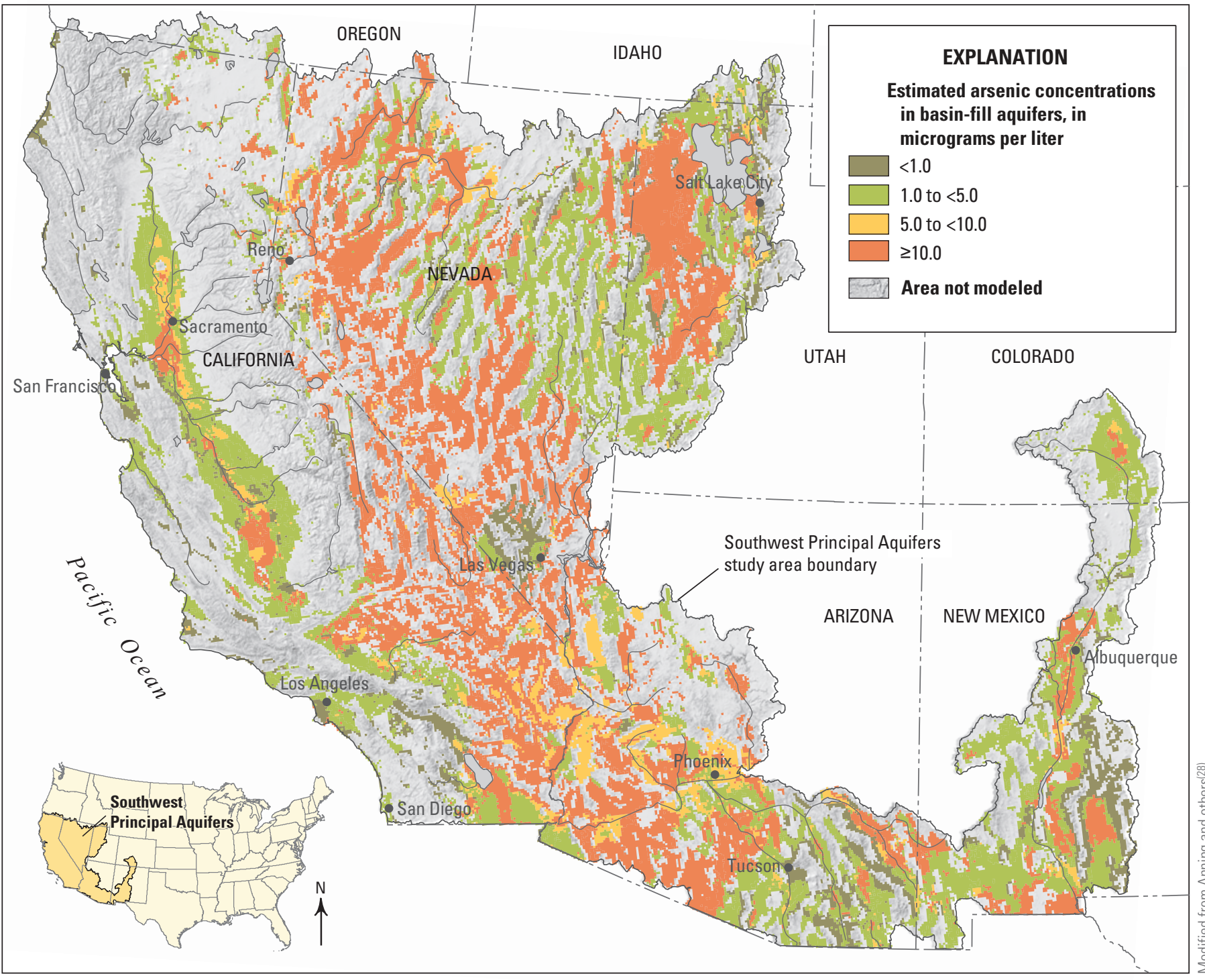

Figure 6-6. Almost half (43 percent) of the areal extent of Southwest basins likely has arsenic concentrations in groundwater that equal or exceed the MCL of $10 \mu \mathrm{g} / \mathrm{L}$, on the basis of a statistical model. Proximity to volcanic rocks, an arid climate, and lack of groundwater drainage from a basin contribute to high arsenic concentrations. If used for public supply, groundwater in areas with these conditions likely would require treatment to decrease arsenic concentrations to levels acceptable for drinking. 


\section{Uranium}

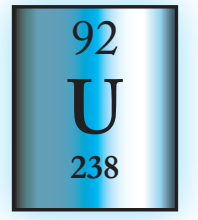

About one in four samples from domestic wells in the eastern San Joaquin Valley, California, contained uranium at a concentration that exceeded the Maximum Contaminant Level.
Uranium concentrations in Southwest basin-fill aquifers are high where uranium-rich rocks and geochemical conditions that promote the release of uranium from those rocks are present. Concentrations exceeded the MCL of $30 \mu \mathrm{g} / \mathrm{L}$ in about 7 percent of samples from drinkingwater wells. Recharge of excess irrigation water and pumping from deeper parts of the aquifer can cause downward movement of shallow groundwater enriched in uranium to parts of the aquifer used for drinking-water supply.

Uranium is a radioactive trace element present in many rocks and basin-fill sediments in the Southwest. The USEPA MCL for uranium is $30 \mu \mathrm{g} / \mathrm{L}$, largely because of the potential for kidney damage that could arise from long-term exposure through drinking water.(29)

Uranium concentrations exceeded the MCL in about 7 percent of drinking-water wells sampled as part of the studies in the Southwest (table 5-1). Domestic wells with uranium concentrations that exceeded the MCL were primarily in the agricultural eastern Central Valley, California, where 24 percent of the wells had concentrations greater than the MCL (table 6-2).
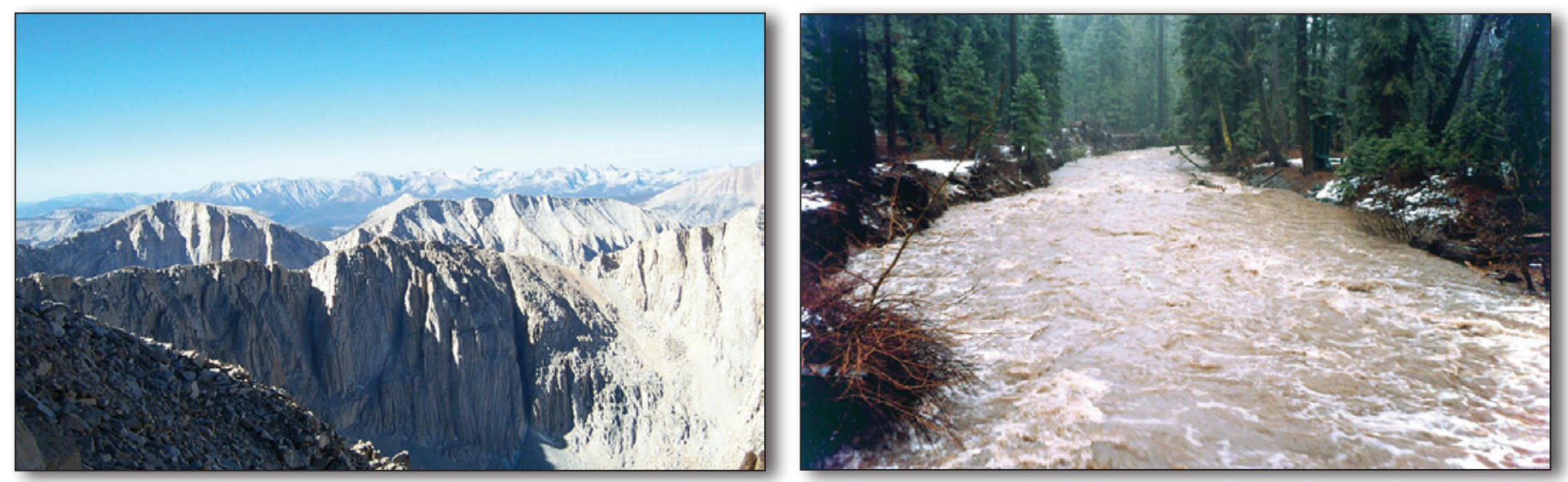

Photographs: Left, David Berger; right, Tim Rowe; bottom, Michael Rosen, USGS

Granitic rock, like that at the top of Mount Whitney in the Sierra Nevada (upper left), commonly contains uranium. As the granitic rock erodes, the fragments are transported by streams and rivers to lower altitudes (sediment-laden water in Ward Creek near Lake Tahoe, upper right). Over geologic time, this eroded material accumulates in the downstream basin to form the basin-fill aquifer (Eagle Valley, Nevada, bottom). As groundwater moves through the basin-fill aquifer, it dissolves some of the constituents-including uraniumin the sediment.

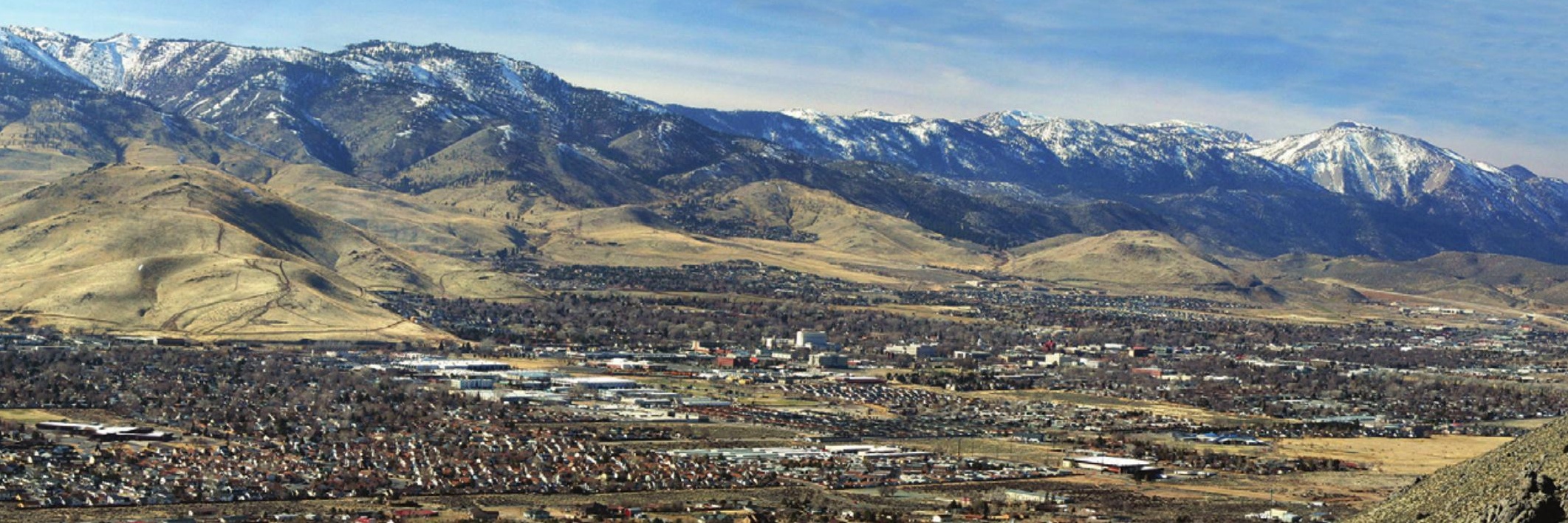


Shallow groundwater in Southwest basins generally has higher concentrations of uranium than water in deeper parts of the aquifer (fig. 6-7). The potential for movement of uranium from shallow to deeper parts of the aquifer where groundwater is used for public supply is of concern in the eastern San Joaquin Valley, because uranium occurs in the sediments and human activities have increased the downward movement of shallow groundwater (see sidebar, Humaninduced changes to the Central Valley aquifer system, California, p. 36). About 14 percent of uranium concentrations in 1,307 wells sampled by the USGS during 1980-2009-78 percent of these were sampled as part of NAWQA studies - were greater than the MCL (fig. 6-8).

Table 6-2. Percentage of samples with a uranium concentration that exceeded the MCL of $30 \mu \mathrm{g} / \mathrm{L}$. See appendix 2, table A2-2, for the number of wells sampled.

\begin{tabular}{lccccc}
\hline \multicolumn{1}{c}{ Type of well } & $\begin{array}{c}\text { All aquifers } \\
\text { in Southwest } \\
\text { Principal Aquifers } \\
\text { group }\end{array}$ & $\begin{array}{c}\text { Basin and Range } \\
\text { basin-fill } \\
\text { aquifers }\end{array}$ & $\begin{array}{c}\text { Central Valley } \\
\text { aquifer system }\end{array}$ & $\begin{array}{c}\text { California Coastal } \\
\text { Basin aquifers }\end{array}$ & $\begin{array}{c}\text { Rio Grande } \\
\text { aquifer system }\end{array}$ \\
\hline Urban land-use monitoring wells & 18 & 19 & 0 & 48 & 9.1 \\
Agricultural land-use monitoring wells & 15 & 31 & 19 & Not sampled & 6.6 \\
Domestic wells & 12 & 3.1 & 24 & 0 & 4.0 \\
Public-supply wells & 1.2 & 2.0 & 0 & 1.1 & 0 \\
All sampled wells & 11 & 9.9 & 18 & 8.9 & 5.4 \\
\hline
\end{tabular}

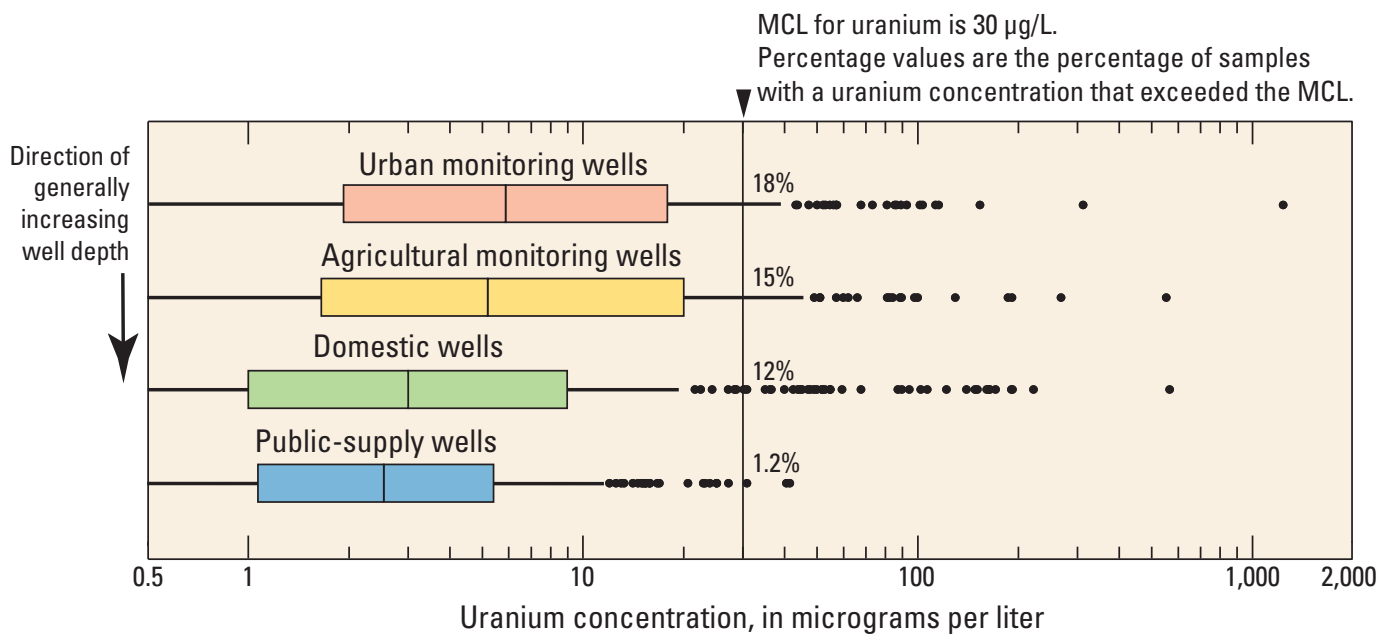

See sidebar, Boxplots, p. 53

Figure 6-7. Median concentrations of uranium are higher in shallow parts of Southwest basin-fill aquifers than in deeper parts, which are tapped by domestic and public-supply wells. Nonetheless, concentrations of uranium exceeded the MCL in 12 percent of domestic wells, which are not required to be monitored or treated. 


\section{Uranium can be an indicator of other radionuclides in groundwater}

Uranium concentrations in crystalline rock aquifers in the northeastern United States indicate the possible presence of three other radionuclides with human-health concerns: radon, radium, and gross alpha radioactivity. (71) Uranium, which is relatively easy to analyze, could prove to be a useful indicator of radon, radium, and gross alpha radioactivity in Southwest groundwater, where there are few measurements of these radionuclides. Better coverage of uranium concentrations in basin-fill aquifers would therefore address multiple potential human-health concerns, in addition to providing a better understanding of the major factors that affect uranium in the region's groundwater.

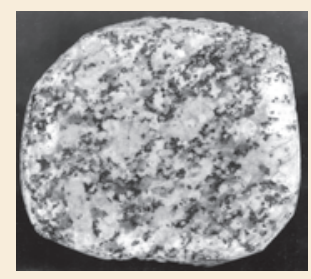

Granite, an igneous rock, can be enriched in uranium.

\section{Measured uranium concentration in basin-fill aquifers}

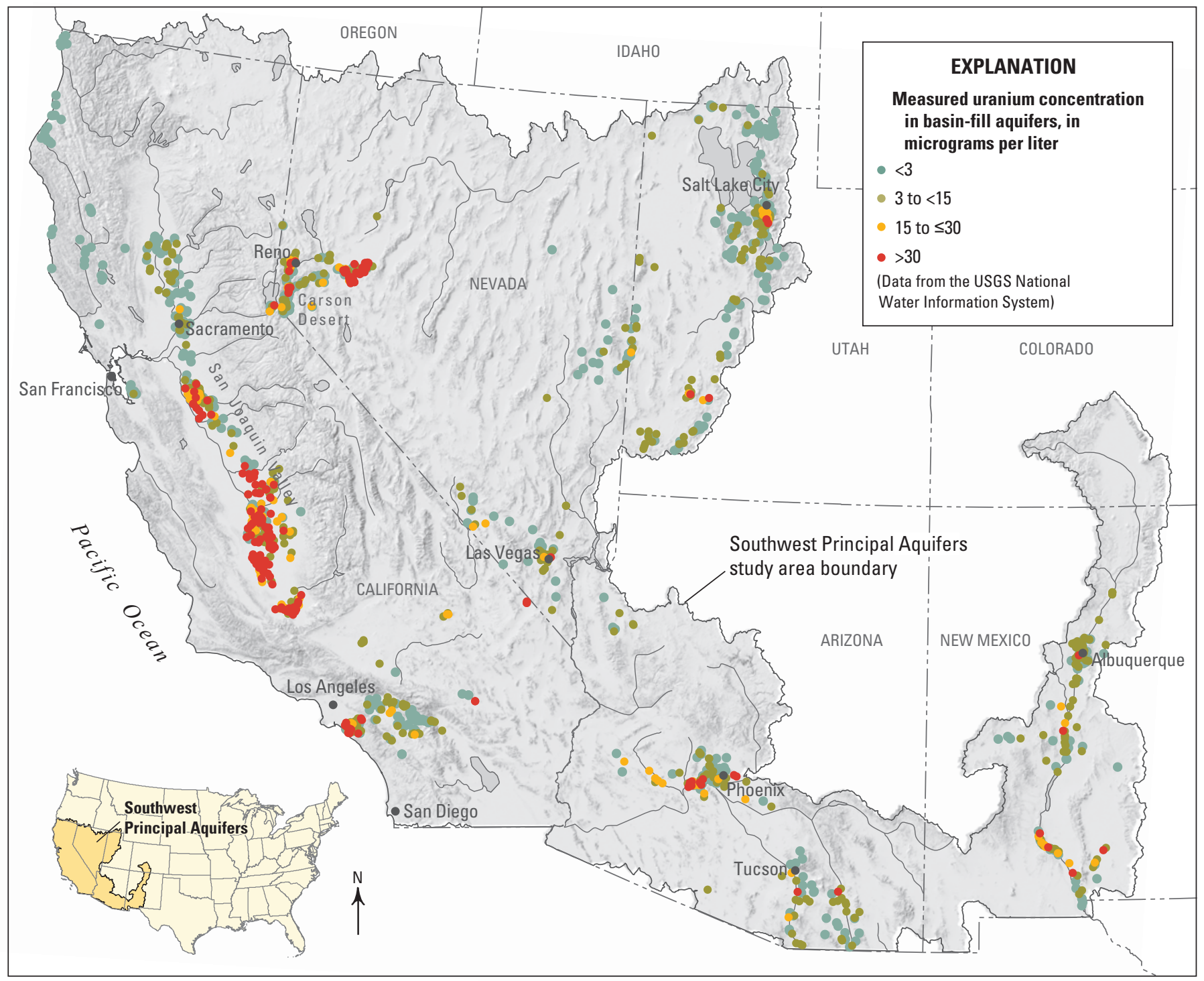

Figure 6-8. Data on uranium concentrations in Southwest groundwater are sparse compared to those for arsenic. Concentrations of uranium in groundwater are elevated in the southern part of the San Joaquin Valley in California and in the Carson Desert in Nevada. Many of these uranium concentrations are in samples from wells less than 50 feet deep that are affected by evaporative concentration and recharge of excess irrigation water. 


\section{Rock Type and Geochemistry Affect Uranium Concentrations in Groundwater}

The main source of uranium in groundwater in Southwest basins is the weathering of metamorphic and intrusive rocks (fig. 3-2), especially granitic rocks, and the sediment derived from these rocks. Large exposures of granitic rocks are less widely distributed than are volcanic rocks in the Southwest, so there are fewer areas where high uranium concentrations in groundwater are a problem compared to arsenic. Evaporative concentration in low-lying areas of constricted and closed basins combined with the transport of evaporite salts through the soil by irrigation water, such as in the southern San Joaquin Valley in California, ${ }^{(30)}$ can cause uranium concentrations in shallow groundwater to increase.

Redox conditions, $\mathrm{pH}$, and the presence of dissolved carbonate species (mostly carbonate and bicarbonate) influence uranium concentrations in groundwater. In sand and gravel aquifers across the United States, uranium tends to occur in groundwater that is oxic and has a pH equal to or greater than 7.(31) High concentrations of bicarbonate increase the solubility of uranium in oxygenated groundwater. (32) Uranium bonds strongly (complexes) with bicarbonate; as a result, the uranium is less likely to sorb to aquifer sediments. This tendency for uranium to be dissolved in Southwest groundwater is apparent in the relation between uranium concentrations and alkalinity, a measure of the capacity of water to neutralize or buffer acids (bicarbonate is an important buffer) (fig. 6-9). When high concentrations of carbonate species are not present in oxic groundwater and $\mathrm{pH}$ is near neutral, uranium does not remain in solution but sorbs to metal oxides, organic material, and clays in the aquifer sediments.(33) In anoxic, strongly reducing groundwater (see sidebar, How do redox reactions work?, p. 31), uranium also is removed from solution, not through adsorption but through the precipitation of stable uranium-forming minerals, which results in low uranium concentrations in groundwater.

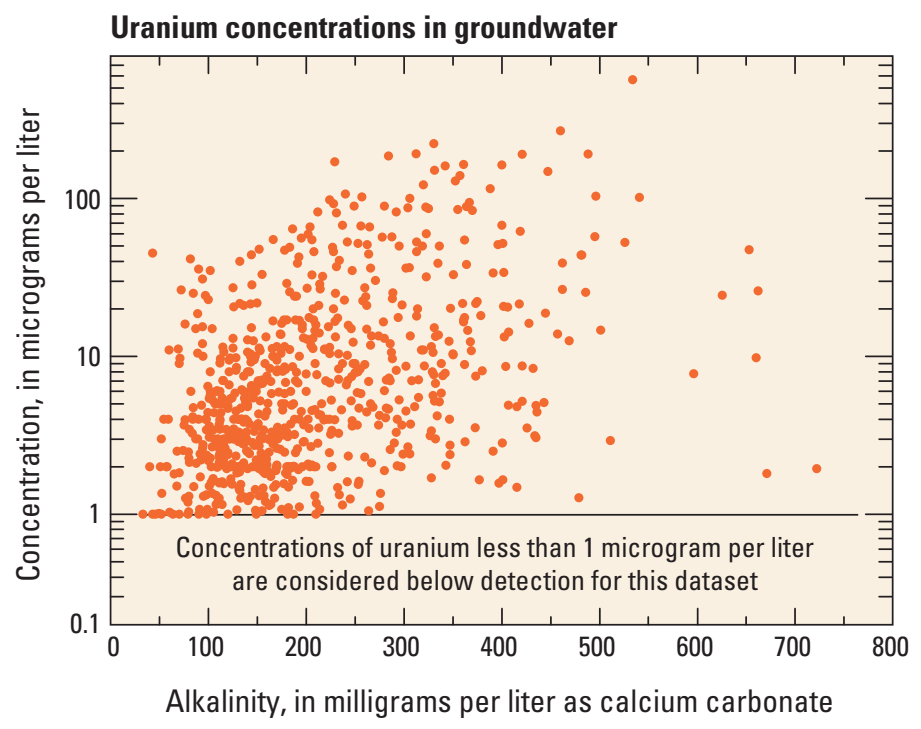

Figure 6-9. In the Southwest, high uranium concentrations generally occur in oxic groundwater that has a relatively high alkalinity (bicarbonate is a large component of alkalinity) because uranium forms soluble complexes with bicarbonate.
Because uranium bonds strongly with bicarbonate, it is not likely to sorb to aquifer sediments and tends to be dissolved in Southwest groundwater.

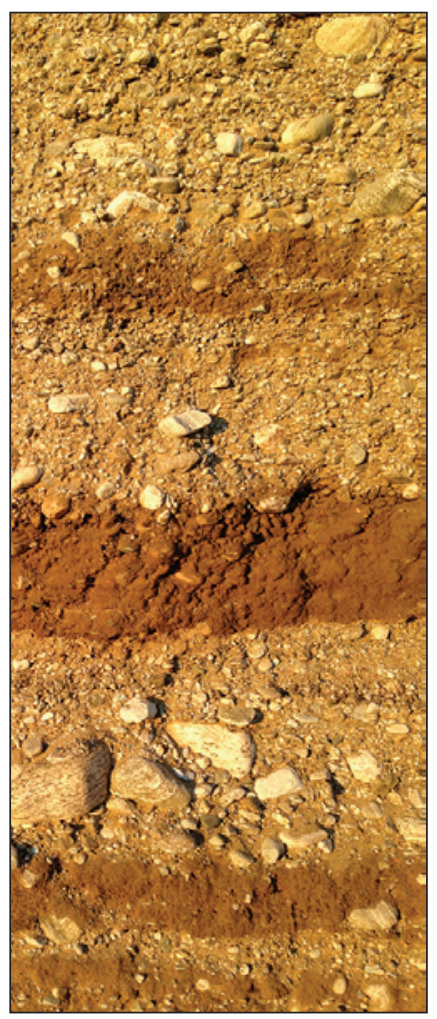

Minerals can be transported by water to basin-fill deposits where they can accumulate. 


\section{Irrigation Has Caused Sediments to Release Uranium Into Shallow Groundwater}

Uranium sorbed to sediment can be released to groundwater by excess irrigation water, as has occurred in the southern Carson Desert in Nevada ${ }^{(18,34)}$ and the eastern San Joaquin Valley in California.(32) Groundwater with elevated concentrations of uranium is widespread in the eastern San Joaquin Valley. About 19 percent of wells (65 of 350) sampled as part of the USGS and California Ground Water Ambient Monitoring and Assessment (GAMA) studies had uranium concentrations that exceeded the MCL of $30 \mu \mathrm{g} / \mathrm{L}$. Concentrations were highest in monitoring wells tapping shallow parts of the aquifer (32 percent exceeded the MCL) and decreased with depth. Uranium concentrations exceeding the MCL were measured in 25 percent of the domestic wells sampled.(32) In contrast, the MCL for uranium was exceeded in less than 3 percent of domestic wells sampled by the NAWQA Program nationally.(35)

Uranium concentrations in shallow groundwater in the eastern San Joaquin Valley are high because of the presence of elevated concentrations of calcium and bicarbonate. Although calcium and bicarbonate occur naturally in groundwater, their concentrations have increased since the 1850 s mainly as a result of agriculture. Plant root respiration and microbial oxidation of organic matter cause calcium carbonate minerals to dissolve into irrigation water that infiltrates into soils. This process leads to increases in both calcium and bicarbonate concentrations in the recharge water that reaches the uranium-bearing aquifer sediments. Uranium sorbed to aquifer sediments bonds with the calcium and bicarbonate and is released into shallow groundwater, which is then transported to deeper parts of the aquifer by pumping (fig. 6-10). Because the developed part of the aquifer system in the eastern San Joaquin Valley is largely oxic, uranium remains dissolved in groundwater and, therefore, poses a threat to the long-term sustainability of the aquifer as a source of drinking water.(32)

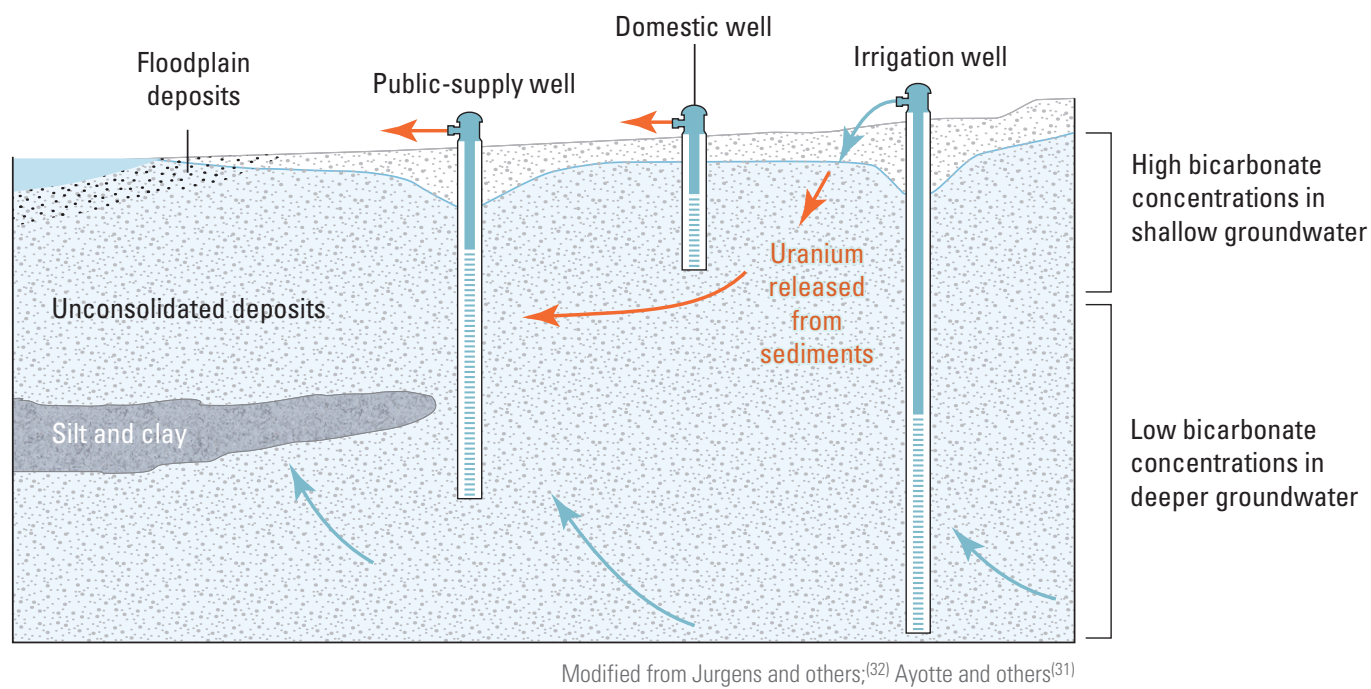

Figure 6-10. Pumping groundwater from deeper parts of the aquifer in the eastern San Joaquin Valley, California, pulls shallow groundwater that can contain relatively high uranium concentrations downward and toward the long screened intervals of pumping wells. The high uranium concentrations in shallow groundwater result from mobilization of uranium in the sediment by bonding with dissolved bicarbonate ions. 


\section{Nitrate}

Nitrate concentrations in most Southwest basin-fill aquifers are low relative to the MCL of $10 \mathrm{mg} / \mathrm{L}$ as nitrogen because of the relatively small amount of land development. In agricultural and urban areas, however, nitrate concentrations are above background levels, and in some areas concentrations in groundwater exceed the MCL. Nitrate concentrations are likely to increase in agricultural and urban areas as nitrate from past fertilizer applications or other sources reaches the water table and makes its way deeper into the aquifer.

The old adage "too much of a good thing" holds true for nitrate. Nitrate and other forms of nitrogen are essential nutrients for human health and the growth of plants and animals. At high concentrations, however, nitrate can pose human-health and ecological risks. The USEPA has set a MCL of $10 \mathrm{mg} / \mathrm{L}$ as nitrogen $(\mathrm{N})$ for nitrate in drinking water to protect against "blue-baby syndrome."(36)

Nitrate is a relatively common groundwater contaminant in Southwest study basins, and concentrations exceeded the MCL in about 11 percent of drinking-water wells sampled as part of the studies in the Southwest (table 5-1). This percentage was much higher for domestic

Much of the information presented in this section is from

the report "Predicted nitrate and arsenic concentrations in basin-fill aquifers of the southwestern United States" (available at http://pubs.usgs.gov/sir/2012/5065/).

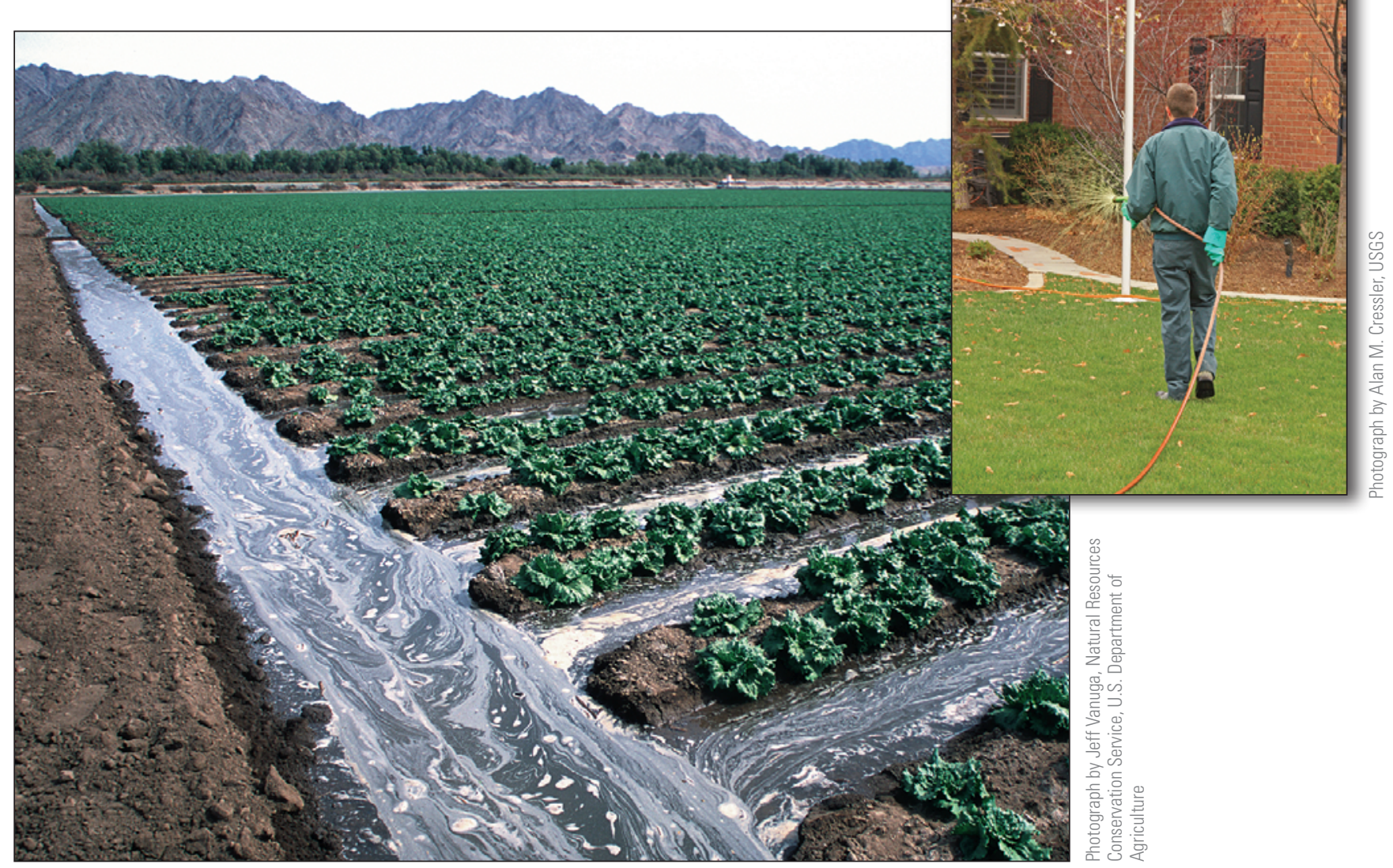

Fertilizers are a source of nitrate. Irrigation of agricultural land (irrigated lettuce field near Yuma, Arizona, on left) and urban and suburban land (fertilizer application to lawn in Orem, Utah, on right) moves some of the nitrate in fertilized soils down to the water table. 
Nitrate concentrations

exceeded the Maximum

Contaminant Level in

18 percent of samples from

domestic wells and in less

than 4 percent of samples

from public-supply wells. wells in some areas - nitrate concentrations exceeded the MCL in 29 percent of domestic wells in the Central Valley aquifer system, which includes the predominantly agricultural eastern San Joaquin Valley (table 6-3). In contrast, nitrate was measured at concentrations greater than the MCL in only 4 percent of domestic wells sampled nationally.(35) The similarity between nitrate concentrations in shallow groundwater samples from monitoring wells in agricultural settings and deeper groundwater from domestic wells (fig. 6-11) likely reflects the effects of agriculture on groundwater quality. About 10 percent of nitrate concentrations in 5,787 wells in the Southwest sampled by the USGS during 1980-2009 (1,070 wells sampled as part of the NAWQA Program) were greater than the MCL (fig. 6-12).

Table 6-3. Percentage of samples with a nitrate concentration that exceeded the MCL of $10 \mathrm{mg} / \mathrm{L}$ as nitrogen. See appendix 2 , table A2-3, for the number of wells sampled.

\begin{tabular}{|c|c|c|c|c|c|}
\hline Type of well & $\begin{array}{l}\text { All aquifers } \\
\text { in Southwest } \\
\text { Principal } \\
\text { Aquifers group }\end{array}$ & $\begin{array}{c}\text { Basin and Range } \\
\text { basin-fill } \\
\text { aquifers }\end{array}$ & $\begin{array}{c}\text { Central } \\
\text { Valley aquifer } \\
\text { system }\end{array}$ & $\begin{array}{c}\text { California Coastal } \\
\text { Basin aquifers }\end{array}$ & $\begin{array}{c}\text { Rio Grande } \\
\text { aquifer system }\end{array}$ \\
\hline Agricultural land-use monitoring wells & 25 & 22 & 20 & Not sampled & 28 \\
\hline Domestic wells & 18 & 11 & 29 & 0 & 0 \\
\hline All sampled wells & 14 & 11 & 22 & 7.7 & 14 \\
\hline
\end{tabular}

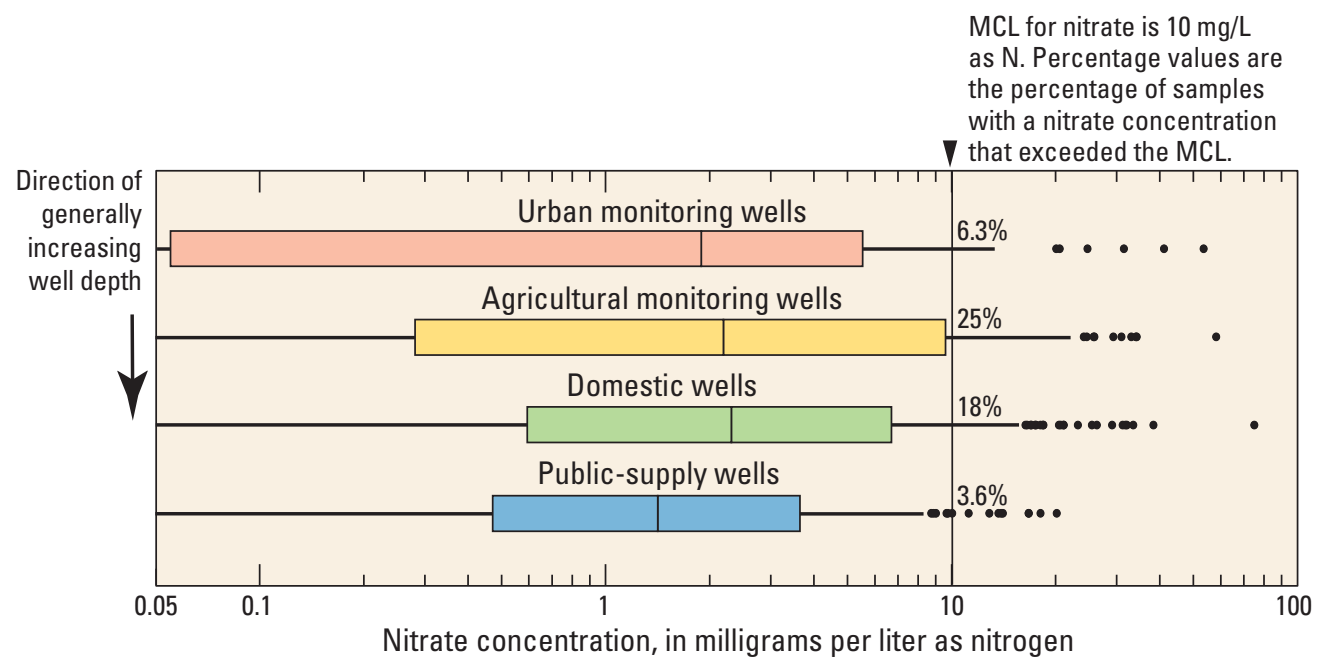

See sidebar, Boxplots, p. 53

Figure 6-11. Median nitrate concentrations were highest in domestic wells, which mostly were located in agricultural areas, and in monitoring wells installed in agricultural areas. Deeper groundwater sampled from public-supply wells, which typically are in urban areas, had the lowest median concentration and the fewest exceedances of the MCL of $10 \mathrm{mg} / \mathrm{L}$ as $\mathrm{N}$. 
Measured nitrate concentration in basin-fill aquifers

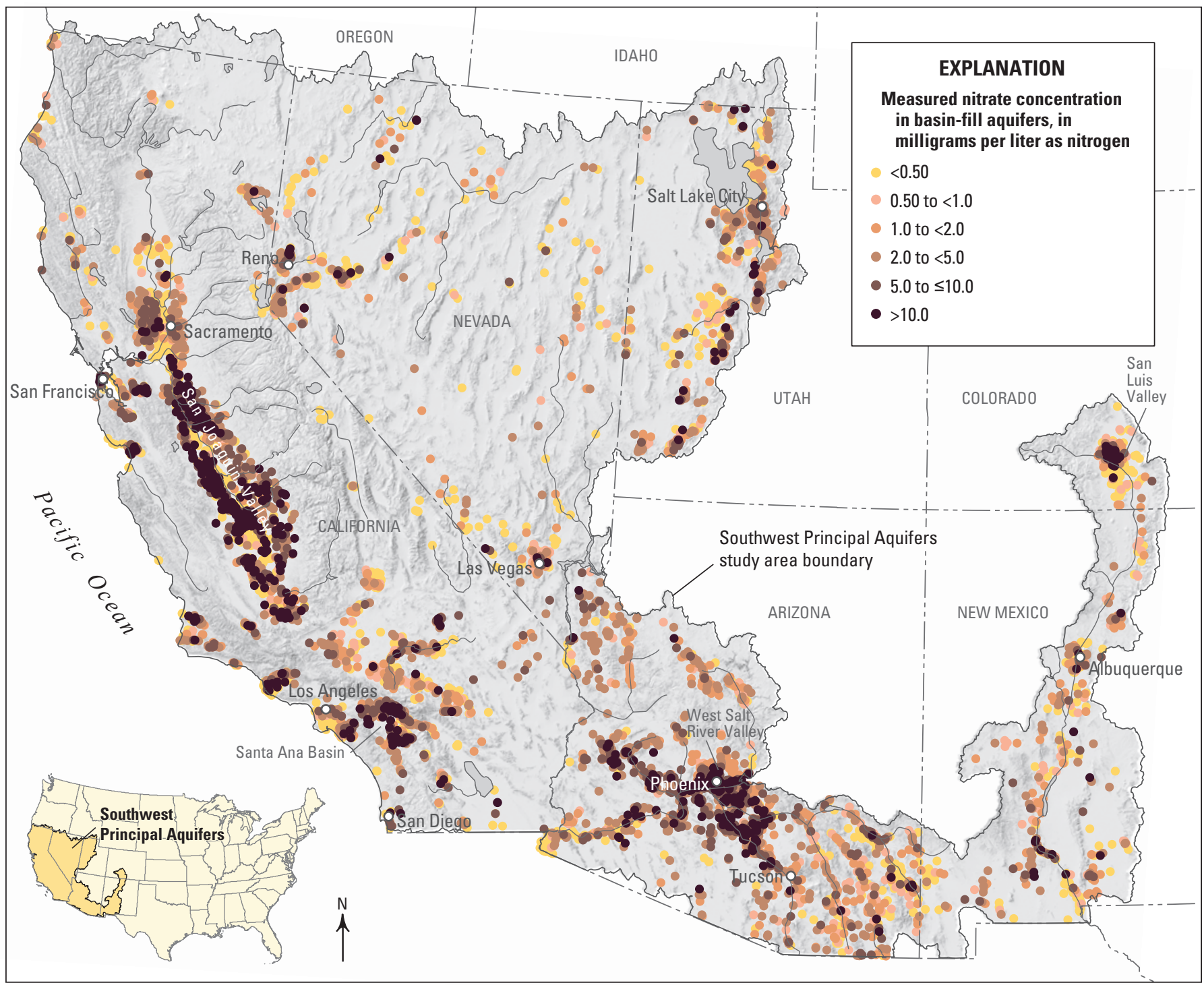

Modified from Anning and others 28.

Figure 6-12. Nitrate concentrations measured in wells that tap basin-fill aquifers in the Southwest mostly represent nitrate in those parts of the groundwater system used for water supply. Areas where nitrate concentrations in wells exceeded the MCL of $10 \mathrm{mg} / \mathrm{L}$ as $\mathrm{N}$ include the West Salt River Valley in Arizona, the Santa Ana Basin and San Joaquin Valley in California, and the San Luis Valley in Colorado.

\section{The cost of nitrate contamination}

In California's San Joaquin Valley, intensive agricultural fertilizer use has resulted in widespread contamination of groundwater with nitrate, including, in some places, groundwater that is pumped for public supply. Many small communities cannot afford to supply water that meets the nitrate drinking-water standard, ${ }^{(72)}$ and some residents with access only to contaminated groundwater are forced to purchase bottled or vended water for drinking.

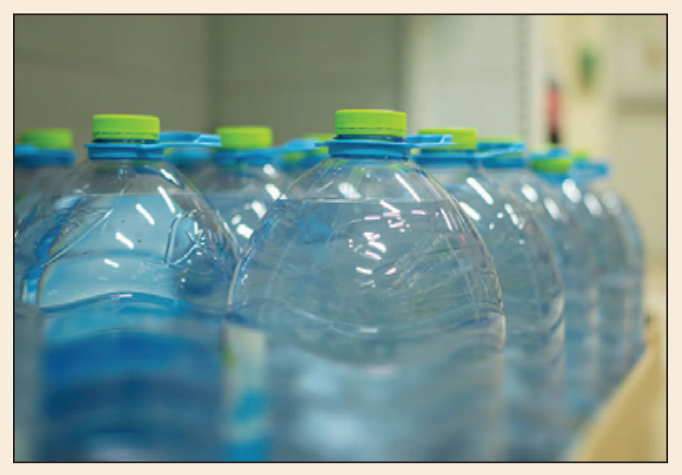


Groundwater is especially vulnerable to nitrate contamination where the water table is shallow and nitrate sources are plentiful.

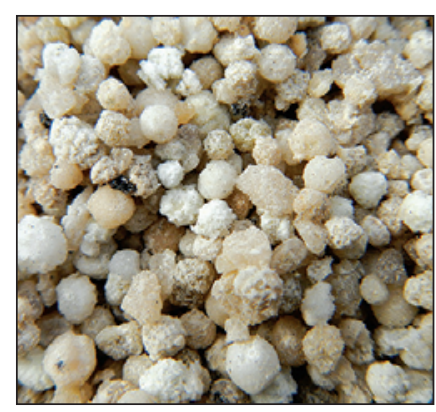

Granular fertilizer containing nitrogen supplies nutrients to lawns where the fertilizer is applied.

\section{Human Activities Can Combine With Natural Factors to Increase Nitrate Concentrations in Groundwater}

Human-related sources of nitrate to Southwest groundwater include fertilizers and manure applied to irrigated fields and turf areas, wastewater from concentrated animal feeding operations, wastewater from septic or sewer systems, and treated urban wastewater applied to irrigated areas. $(19,37)$ Groundwater is especially vulnerable to nitrate contamination where the water table is shallow and nitrate sources are plentiful, although shallow groundwater typically is not used as a source of drinking water in Southwest basins. Nitrate concentrations were greater than $10 \mathrm{mg} / \mathrm{L}$ as $\mathrm{N}$ in 25 percent of shallow agricultural monitoring wells sampled in Southwest agricultural areas (fig. 6-11) —agricultural areas are associated with relatively large amounts of fertilizer and (or) manure applications compared to other types of land cover.

Some natural hydrogeologic and geochemical factors combine with human-related sources and activities to increase the vulnerability of basin-fill aquifers to nitrate contamination (fig. 6-1). The arid climate leads to evaporative concentration, and coarse-grained soils promote rapid infiltration. The presence of dissolved oxygen in groundwater in most areas prevents denitrification (the transformation of nitrate to nitrogen gas) (fig. 6-13).

Wells that pump water from below laterally extensive layers of clay, which impede downward groundwater movement, are less likely than other wells to be affected by nitrate contamination from the land surface. An illustration of this is in the southwestern part of the West Salt River Valley, Arizona. In this agricultural area, the median nitrate concentration in wells screened (open to the aquifer) above an areally extensive clay layer was $19 \mathrm{mg} / \mathrm{L}$ as $\mathrm{N}$-almost twice the MCL — and in wells screened below the clay layer the median was $2 \mathrm{mg} / \mathrm{L}$ as N.(38) If, however, a well penetrates such a clay layer and is screened both above and below the clay layer, the well can be a conduit for vertical groundwater flow and cause mixing of waters with low and high nitrate concentrations (see sidebar, Wells can "short circuit" groundwater flow paths and increase contaminant movement, p. 37).

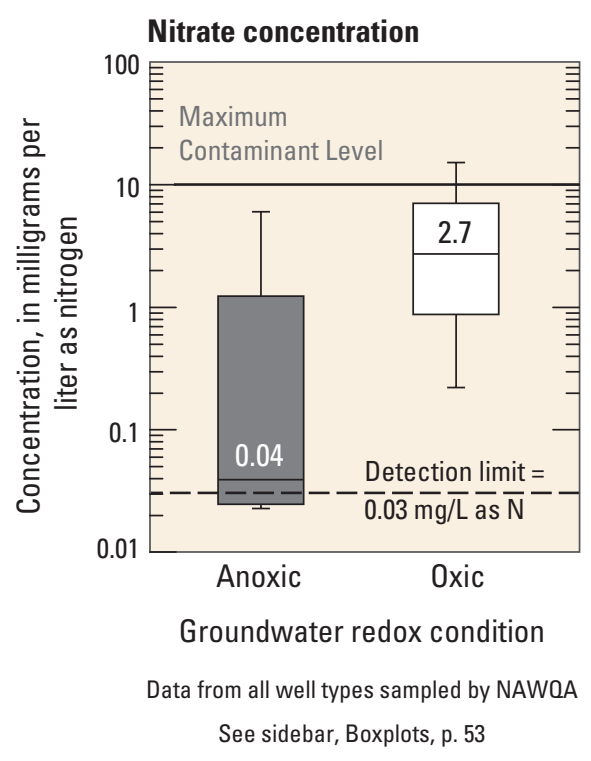

Figure 6-13. Nitrate concentrations commonly are lower in anoxic groundwater than in oxic groundwater because denitrification-the transformation of nitrate to harmless nitrogen gas_-occurs only under anoxic conditions. Most groundwater in Southwest basin-fill aquifers is oxic.

\section{Nitrate Concentrations in Deeper Parts of Basin-Fill Aquifers Can Increase Given Sufficient Time}

Concern about nitrate contamination arises where the shallow part of an aquifer is hydrologically linked to deeper parts that are, or could be, used for drinking water. The movement of nitrate from sources at the land surface to shallow parts of basin-fill aquifers and subsequently to greater depths can take many years, even decades. Because of this long travel time, nitrate concentrations measured in deep groundwater does not reflect the full effect of past and present human activities.

For example, nitrate concentrations in shallow, intermediate, and deeper parts of the basin-fill aquifer in the eastern San Joaquin Valley have increased (fig. 6-14A).(39) This trend is attributed to increases in fertilizer and manure application rates and, therefore, in nitrate concentrations in excess irrigation water that recharges the aquifer. Nitrate concentrations are highest at shallow aquifer depths and are higher at intermediate depths, where domestic wells 
typically are screened, than at greater depths, where publicsupply wells are screened (fig. 6-14B). Concentrations in deeper parts of the aquifer likely will be higher in the future as nitrate-rich groundwater continues to move downward. Because of the travel time required for groundwater to move from the water table to deeper parts of the aquifer, current nitrate concentrations in water from public-supply wells reflect the effects of management practices that occurred 40 to 50 years ago, and current management practices will be reflected in concentrations measured in the future.

In another example, increasing nitrate concentrations in groundwater have been measured in the Carson Valley, Nevada (fig. 6-15). Of 27 monitoring wells sampled during 1985-2001, 15 had an upward trend in nitrate concentration, 3 had a downward trend, and 9 wells had no trend.(40) Most of the wells with upward trends in nitrate concentration were located in areas of septic tank use, which has increased in the Carson Valley over the past 40 years.

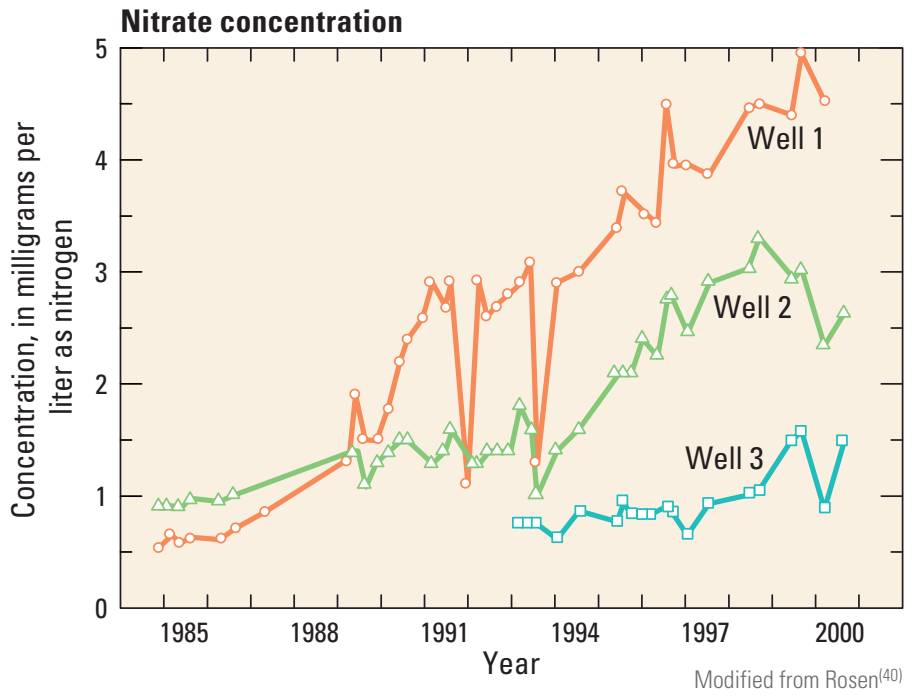

Figure 6-15. In the Carson Valley, Nevada, nitrate from the land surface has moved downward, which has caused nitrate concentrations in groundwater to increase. The higher concentrations largely are a result of contamination from nitrate-rich septictank leachate.

Nitrate concentrations in groundwater
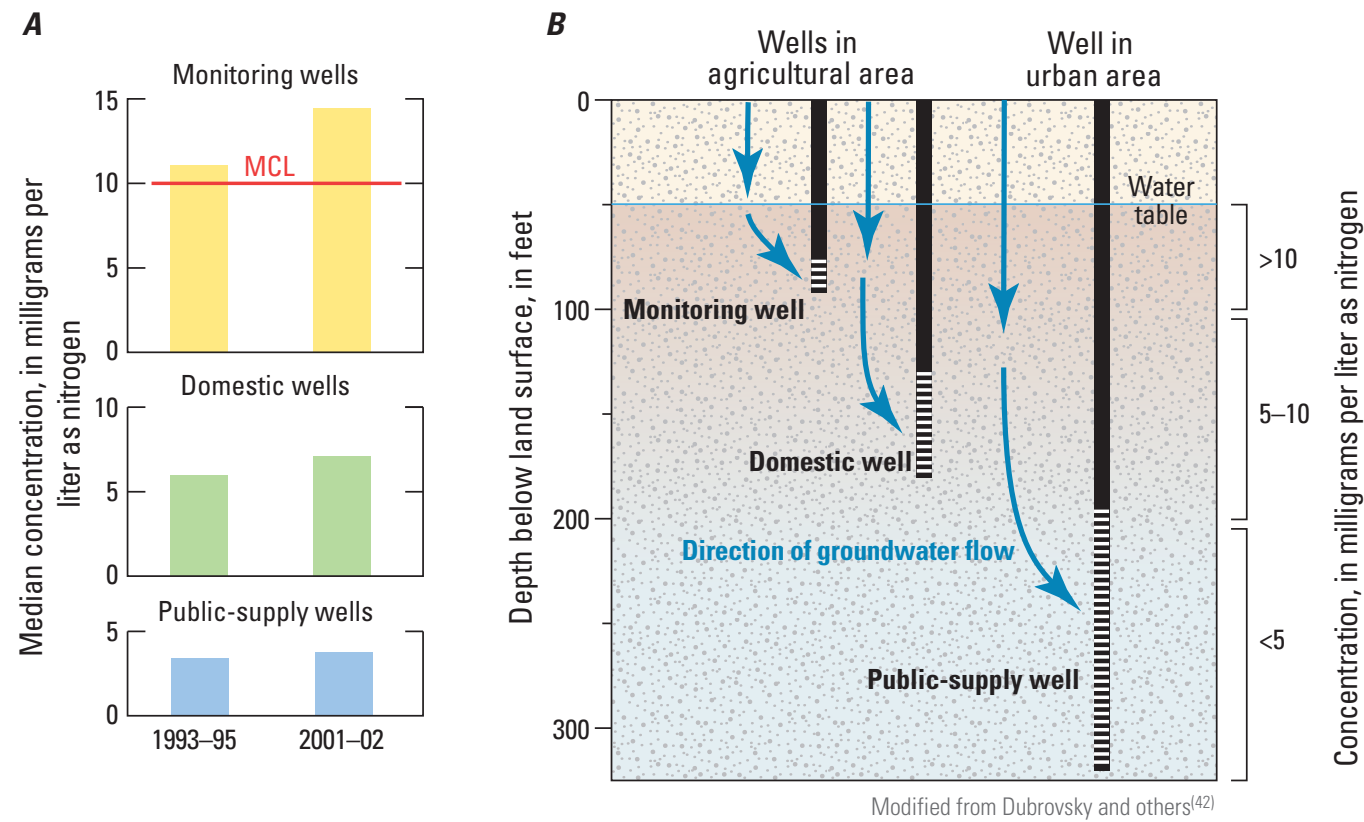

Figure 6-14. A, Nitrate concentrations in groundwater in the eastern San Joaquin Valley, California, have increased, largely because more nitrogen-containing fertilizer is being applied. $B$, Elevated nitrate concentrations in shallow parts of the aquifer reflect recent rates of fertilizer application. Because of the time it takes for groundwater to flow from shallow to deeper parts of the aquifer, nitrate concentrations at greater depths are lower, reflecting past rates of fertilizer application. 


\section{Where Are High Nitrate Concentrations in Basin-Fill Aquifers Located in the Southwest?}

The Southwest is a large area, and nitrate concentrations have not been measured in many parts of its numerous basin-fill aquifers. One way to estimate nitrate concentrations in areas where no measurements are available and to gain a better understanding of concentrations across the region is to use a statistical model. One such statistical model is based on the relation between measured nitrate concentrations in groundwater (fig. 6-12) and spatially distributed information about nitrate sources, climate, soil, land use, and water use.(28)

Estimated nitrate concentration in basin-fill aquifers

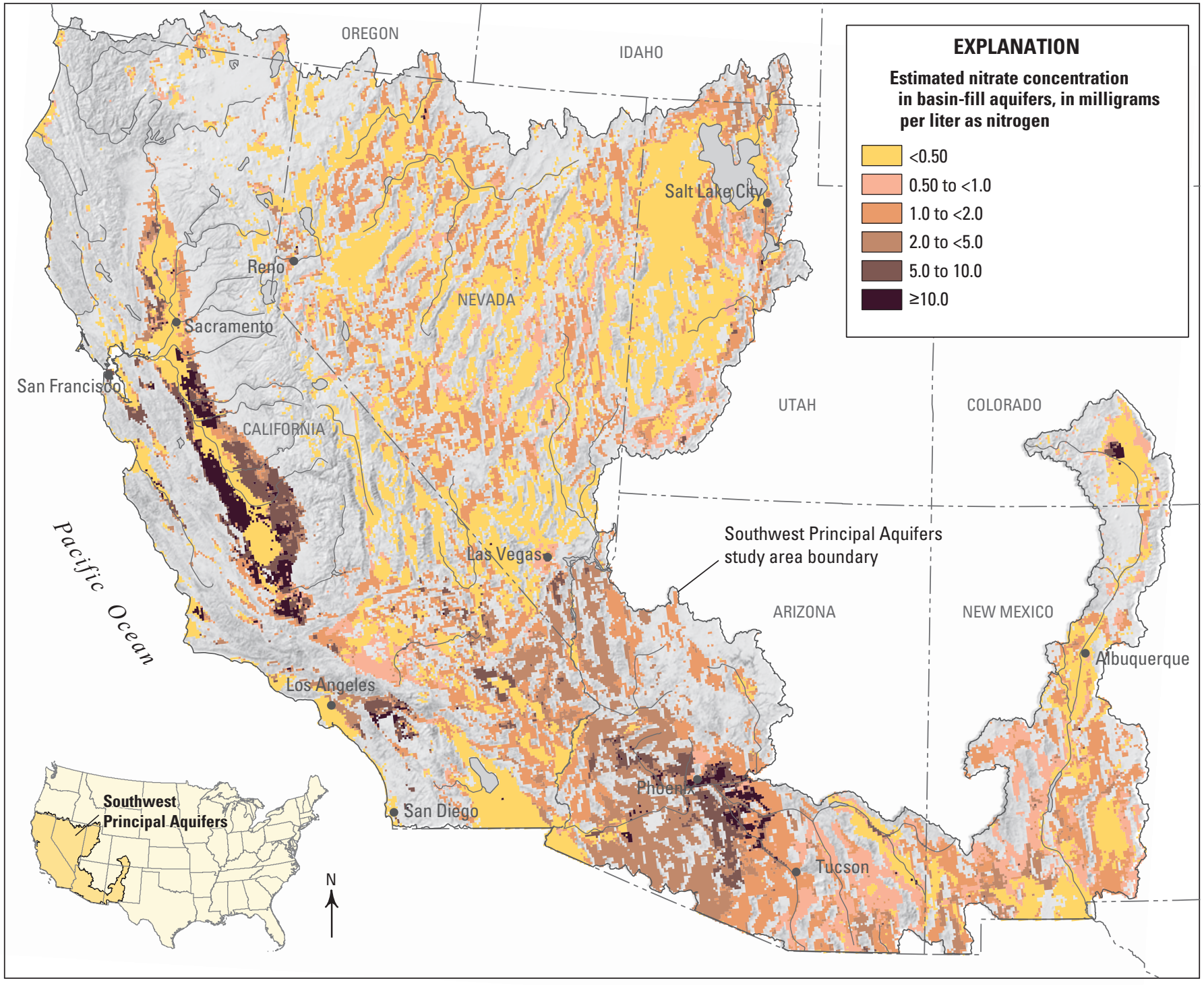

Modified from Anning and others(28)

Figure 6-16 A statistical model used measured nitrate concentrations in groundwater and spatially distributed information about nitrate sources, climate, soil, land use, and water use to estimate nitrate concentrations in parts of basin-fill aquifers where data were not available. Only 2.4 percent of the areal extent of Southwest basin-fill aquifers was estimated to have nitrate concentrations equal to or greater than the MCL of $10 \mathrm{mg} / \mathrm{L}$ as N. 
Nitrate concentrations equal to or greater than the MCL of $10 \mathrm{mg} / \mathrm{L}$ as $\mathrm{N}$ were estimated by the model for only 2.4 percent of the extent of basin-fill aquifers in the Southwest (fig. 6-16). This percentage is small because large areas with undeveloped rangeland are included in the statistical analysis. Areas where there is the most demand for potable groundwater-agricultural and urban land - are most likely to have groundwater with elevated concentrations of nitrate (fig. 6-17).

Denitrification results in decreasing nitrate concentrations in groundwater. Nitrate concentrations are likely to be lower in groundwater from basin lowlands, especially those with wetland areas where anoxic conditions exist and denitrification commonly occurs, than in groundwater from near the basin margin where dissolved oxygen is present (fig. 6-17).
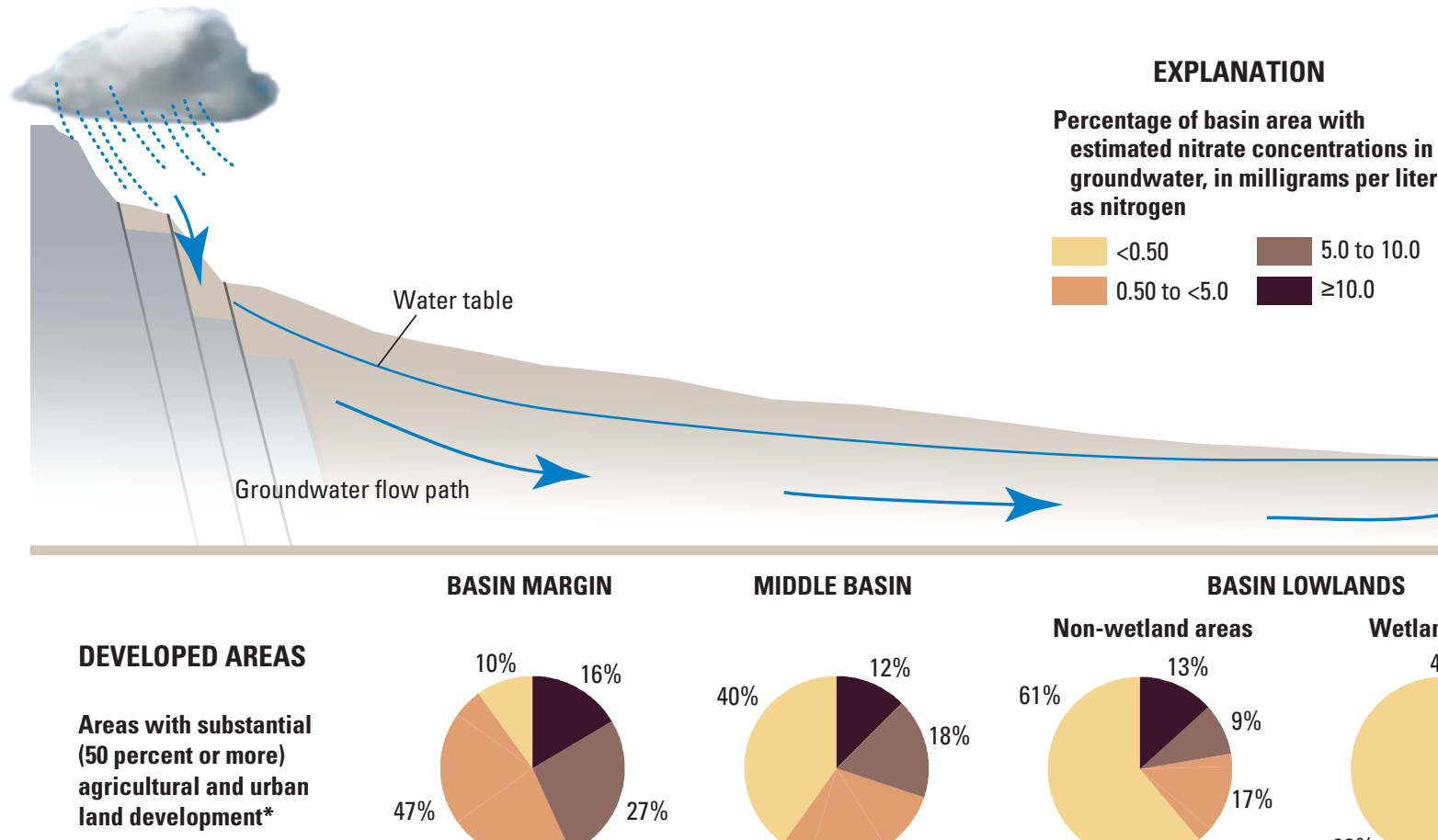
groundwater in milligrams per liter as nitrogen
$<0.50$
5.0 to 10.0
0.50 to $<5.0$
$\geq 10.0$

Water table

$47 \%$

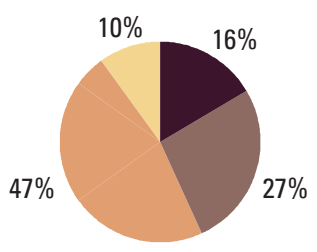

MIDDLE BASIN

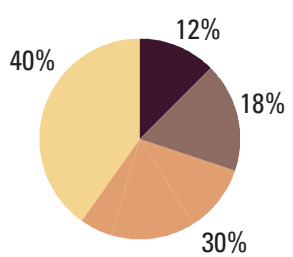

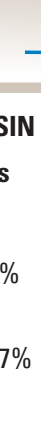

N LOW

\section{UNDEVELOPED AREAS}

Areas with minimal (less than 5 percent) land development*
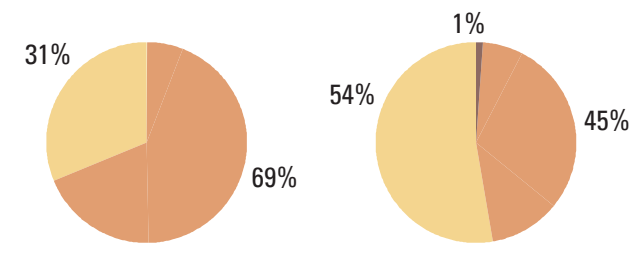
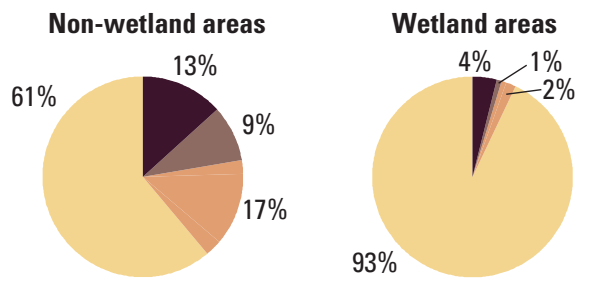

* This summary excludes areas with

Sonoran Desert biotic communities.

Figure 6-17. Estimated concentrations of nitrate are higher in Southwest basin-fill aquifers where the overlying land is substantially developed for agricultural or urban uses than in areas with minimal land development. 


\section{Groundwater in the Southwest Has a Wide Range in Background Nitrate Concentrations}

Nitrate in some Southwest groundwater can come from natural sources and processes. Precipitation in the Southwest contains concentrations of nitrate plus ammonium dissolved in rain that range from about 0.50 to $2.0 \mathrm{mg} / \mathrm{L}$ as N.(41) The nitrogen that is not taken up by plants or stored in soils and the underlying unsaturated zone is carried in recharge water down into the basin-fill aquifers. For much of the region, nitrate concentrations measured in groundwater are less than

\section{Estimated nitrate concentrations in Sonoran Desert groundwater}

Area underlying Sonoran Desert biotic communities with estimated nitrate concentration in groundwater

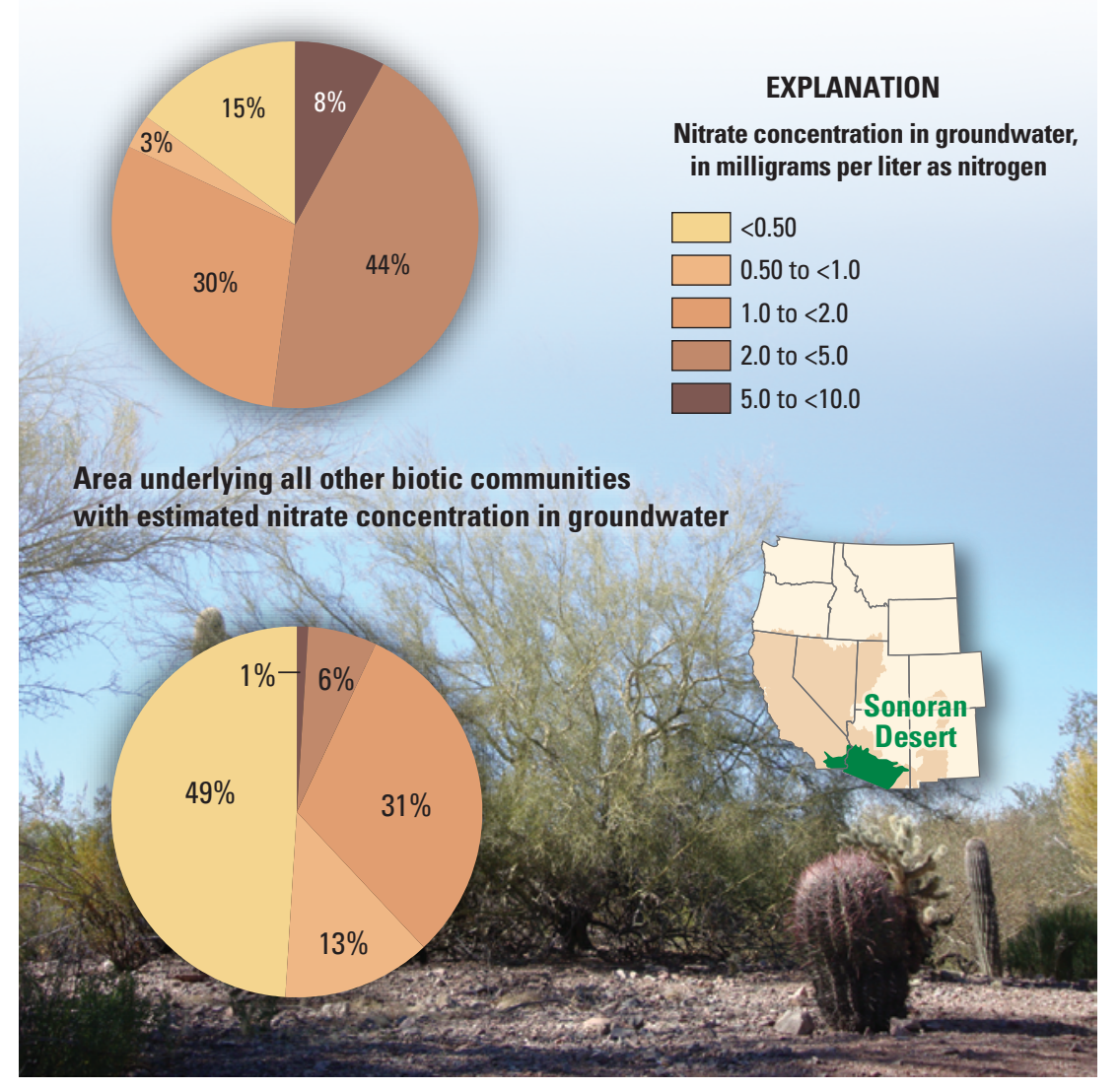

Modified from Anning and others(28)
$2.0 \mathrm{mg} / \mathrm{L}$ as $\mathrm{N}$, and in many areas concentrations are less than $0.50 \mathrm{mg} / \mathrm{L}$ as $\mathrm{N}$ (fig. 6-12).(28) These concentrations of nitrate in Southwest groundwater are similar to the national background concentration of about $1.0 \mathrm{mg} / \mathrm{L}$ as $\mathrm{N}$ estimated for areas with minimal effects from human activities. ${ }^{(42)}$

Soils and plants in some areas of the Southwest contribute nitrate to groundwater. The atmosphere contains mostly nitrogen gas, which is converted to nitrate by bacteria in the soil and in the roots of some desert plants (legumes). For groundwater underlying biotic communities where legumes are common in the Sonoran Desert in southeastern California and southwestern Arizona, nitrate concentrations are commonly measured (fig. 6-12) and estimated to be (figs. 6-16 and 6-18) $5.0 \mathrm{mg} / \mathrm{L}$ as $\mathrm{N}$ and as high as $10.0 \mathrm{mg} / \mathrm{L}$ as $\mathrm{N}$ in some places, including areas with no agriculture or urbanization. In fact, background concentrations in Sonoran Desert groundwater can exceed concentrations in other parts of the Southwest and the Nation that are elevated as a result of human activities. A substantial amount of nitrate has accumulated in the unsaturated zone beneath desert soils in parts of California, Nevada, Arizona, and New Mexico - if development of these lands results in additional recharge that transports the nitrate to the aquifer, it could pose a concern for groundwater contamination.(43)

Figure 6-18. Desert legumes, such as mesquite, ironwood, smoke, and palo verde (shown in photograph) trees, convert nitrogen gas in the atmosphere to nitrate, which they release into the soil. These plants often grow along desert washes (dry streambeds). When it rains, some of the water that runs into the washes becomes groundwater recharge that moves the nitrate from the soil down to the aquifer. Legumes are common in Sonoran Desert biotic communities, and nitrate concentrations are estimated to be higher in the underlying groundwater in these communities (darker shades in pie diagrams) than in other biotic communities in the Southwest. 


\section{Dissolved Solids}

One of every four drinking-water wells sampled in the Southwest contained dissolved solids at a concentration that exceeded the SMCL of $500 \mathrm{mg} / \mathrm{L}$, which can give water an unpleasant taste. Elevated dissolved-solids concentrations in groundwater are the result of natural processes, such as dissolution and evaporative concentration, and humanrelated sources and alterations of groundwater flow systems. Artificial recharge and well pumping in several basins have caused dissolved solids to move from shallow parts of aquifers to deeper parts used for water supply. Because of its effect on the availability of potable and irrigation water, elevated dissolved-solids concentrations are an important water-quality concern in many areas of the Southwest.

High dissolved-solids concentrations (see sidebar, What are dissolved solids?, this page) in water used for domestic, public, industrial, and agricultural supply can cause numerous problems. These problems can include an objectionable taste, higher water-treatment costs, greater use of detergents and soaps because of more water hardness, precipitation of minerals in plumbing, staining, corrosion of metallic surfaces, reduced equipment lifespan, and restricted use for irrigation. The USEPA has established a nonenforceable secondary drinking-water standard (SMCL) for dissolved solids of $500 \mathrm{mg} / \mathrm{L}$ because of concerns related to aesthetic effects rather than human-health effects. Elevated concentrations limit which crops will grow or result in decreased crop yields.

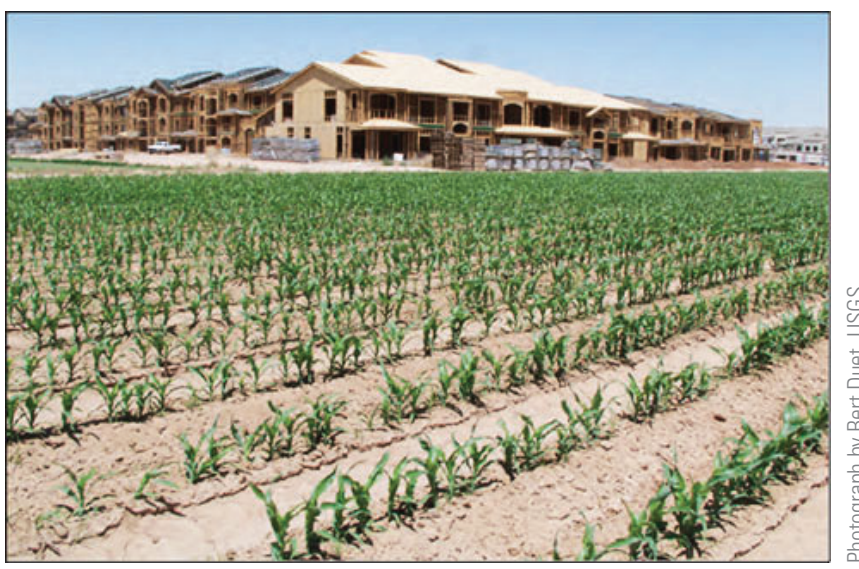

Agricultural or urban development of an arid basin, such as the West Salt River Valley near Phoenix, Arizona, often results in dissolved solids being added to surface water before the water recharges the underlying basin-fill aquifer.

Much of the information presented in this section is from the report "Dissolved solids in basin-fill aquifers and streams in the southwestern United States" (available at $h$ ttp://pubs.usgs.gov/sir/2006/5315/).

\section{What are dissolved solids?}

Dissolved-solids concentration is a measure of all substances, both inorganic and organic, dissolved in water. Major ions (calcium, magnesium, sodium, potassium, bicarbonate, sulfate, chloride, nitrate, and silica) typically make up most of the dissolved solids in water. Dissolvedsolids concentration is reported in milligrams per liter $(\mathrm{mg} / \mathrm{L})$ and represents the mass of dry solids that remain after all the water in a 1-liter sample is evaporated at a temperature of 180 degrees Celsius $\left({ }^{\circ} \mathrm{C}\right)$. Potable water generally is considered to have less than $1,000 \mathrm{mg} / \mathrm{L}$ dissolved solids. Water with greater than $1,000 \mathrm{mg} / \mathrm{L}$ dissolved solids is used for domestic supply in areas where water of lower dissolved-solids content is unavailable, but water containing more than $3,000 \mathrm{mg} / \mathrm{L}$ generally is too salty to drink. ${ }^{(73)}$
The word "salinity" describes the amount of salt in a water sample and, because salts make up the bulk of dissolved solids in water, the terms "salinity" and "dissolved solids" commonly are used interchangeably in the Southwest.

[mg/L, milligrams per liter]

\begin{tabular}{ll}
\hline \multicolumn{2}{c}{$\begin{array}{c}\text { Terms commonly used to describe ranges of dissolved-solids } \\
\text { concentrations in water }\end{array}$} \\
\hline Fresh & Less than $1,000 \mathrm{mg} / \mathrm{L}$ \\
\hline Brackish & $1,000-10,000 \mathrm{mg} / \mathrm{L}$ \\
\hline Slightly saline & $1,000-3,000 \mathrm{mg} / \mathrm{L}$ \\
\hline Moderately saline & $3,000-10,000 \mathrm{mg} / \mathrm{L}$ \\
\hline Very saline & $10,000-35,000 \mathrm{mg} / \mathrm{L} *$ \\
\hline Brine & Greater than $35,000 \mathrm{mg} / \mathrm{L}$ \\
\hline *Ocean water is about $35,000 \mathrm{mg} / \mathrm{L}$. \\
$\begin{array}{l}\text { Concentration ranges from Alley }(73) \\
\text { Association. }{ }^{(82)}\end{array}$ \\
\hline
\end{tabular}


Dissolved-solids

concentrations exceeded

the Secondary Maximum

Contaminant Level in about

one-quarter of drinking-

water wells sampled.
Dissolved-solids concentrations exceeded the SMCL of $500 \mathrm{mg} / \mathrm{L}$ in 26 percent of drinking-water wells sampled as part of the studies in the Southwest (table 5-2). Of the four Southwest Principal Aquifers, Basin and Range basin-fill aquifers had the highest percentage of samples from all wells with concentrations greater than $500 \mathrm{mg} / \mathrm{L}$ (table 6-4). Higher dissolved-solids concentrations typically were measured in shallow groundwater in agricultural and urban areas than in deeper groundwater used for drinking (fig. 6-19). Most groundwater in Southwest basin-fill aquifers has less than $1,000 \mathrm{mg} / \mathrm{L}$ dissolved solids, but concentrations can exceed $10,000 \mathrm{mg} / \mathrm{L}$ in some areas (fig. 6-20).

Table 6-4. Percentage of samples with a dissolved-solids concentration that exceeded the SMCL of $500 \mathrm{mg} / \mathrm{L}$. See appendix 2, table A2-2, for the number of wells sampled.

\begin{tabular}{lccccc}
\hline \multicolumn{1}{c}{ Type of well } & $\begin{array}{c}\text { All aquifers } \\
\text { in Southwest } \\
\text { Principal Aquifers } \\
\text { group }\end{array}$ & $\begin{array}{c}\text { Basin and Range } \\
\text { basin-fill } \\
\text { aquifers }\end{array}$ & $\begin{array}{c}\text { Central Valley } \\
\text { aquifer system }\end{array}$ & $\begin{array}{c}\text { California Coastal } \\
\text { Basin aquifers }\end{array}$ & $\begin{array}{c}\text { Rio Grande } \\
\text { aquifer system }\end{array}$ \\
\hline Urban land-use monitoring wells & 64 & 66 & 35 & 96 & 59 \\
Agricultural land-use monitoring wells & 45 & 50 & 42 & Not sampled & 45 \\
Domestic wells & 31 & 37 & 27 & 11 & 40 \\
Public-supply wells & 19 & 26 & 6.7 & 20 & 7.1 \\
\hline All sampled wells & 40 & 47 & 30 & 34 & 40 \\
\hline
\end{tabular}

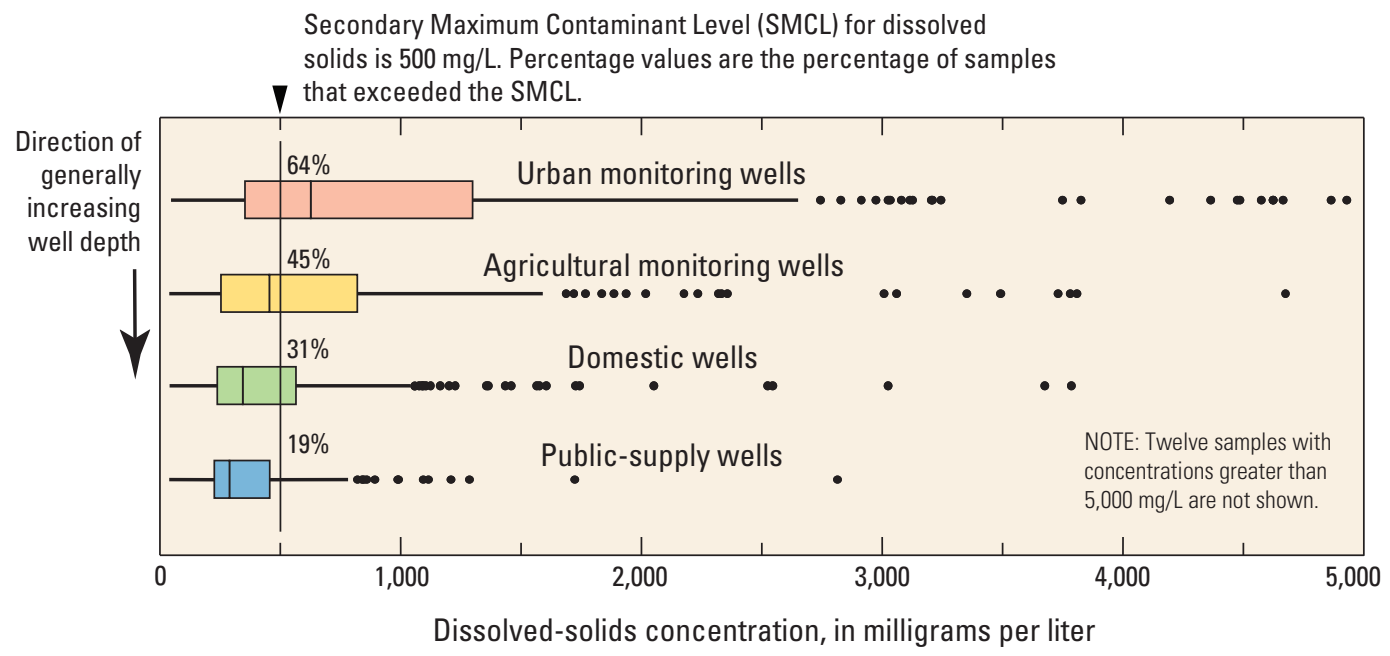

See sidebar, Boxplots, p. 53

Figure 6-19. Dissolved-solids concentrations generally are higher in shallow parts of Southwest basinfill aquifers than in deeper parts, which are the source of groundwater commonly used for drinking. 
Measured dissolved-solids concentration in basin-fill aquifers

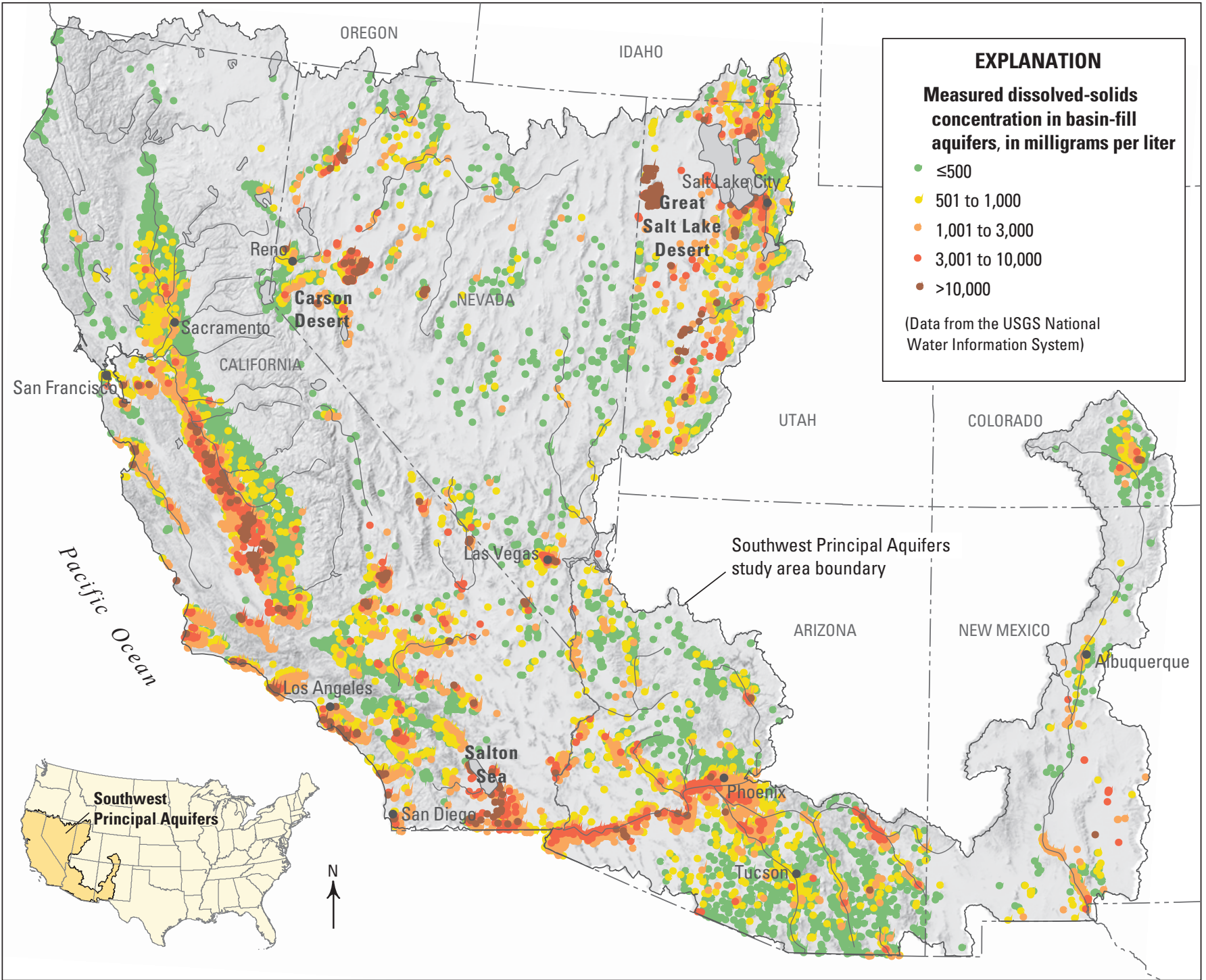

Figure 6-20. Dissolved-solids concentrations measured in Southwest basin-fill aquifers typically are highest (more than 10,000 mg/L) in topographically low areas of closed basins, such as the Great Salt Lake Desert in western Utah and the Salton Sea area in southern California. As part of USGS studies in the Southwest, dissolved solids were measured in more than 21,000 wells that tap basin-fill aquifers. More than half of these groundwater samples had dissolved-solids concentrations greater than the SMCL of $500 \mathrm{mg} / \mathrm{L}$. 


\section{Natural Factors Combine With Land and Water Development to Increase Dissolved Solids in Groundwater}

High concentrations of dissolved solids in groundwater occur naturally in many Southwest basins as a result of minerals dissolving from easily weathered rocks in the surrounding mountains and from sediments within the alluvial basins. Some types of rocks are more soluble than others, resulting in greater concentrations of dissolved solids in streams and groundwater. Given similar climate, land cover, and geomorphology, sedimentary rocks - including shale, carbonate rocks, and evaporites - contribute about 20 times more dissolved solids to streams than do crystalline rocks (such as granite).(44) Groundwater also receives more dissolved solids from sedimentary rocks and sediment derived from these rocks than from crystalline rocks.

Dissolved-solids concentrations tend to increase naturally as groundwater moves through the aquifer from basin margins to lower lying discharge areas (see figure 3-3) because of mineral dissolution. The upward movement of mineralized groundwater of deep and (or) geothermal origin along faults is another geologic source of elevated dissolved-solids concentrations to basin-fill aquifers (fig. 6-1A). Evaporative concentration can cause dissolved solids to accumulate in the groundwater and soils over time in discharge areas, particularly in constricted or closed basins, such as near the Great Salt Lake in Utah. Concentrations can become so high that the groundwater is unsuitable for drinking, irrigation, or other uses.

The same processes - dissolution and evapotranspiration - that concentrate dissolved solids in water that naturally recharges aquifers also affect recharge from excess agricultural and urban irrigation and other human activities. Substantial amounts of dissolved solids have accumulated in heavily irrigated agricultural areas, such as in parts of the Gila River Basin in southwestern Arizona, as a result of evapotranspiration. The highest dissolved-solids accumulation rate in the Southwest occurs in the Salton Sea area in southern California - a closed basin where water imported for irrigation undergoes evapotranspiration.(44)

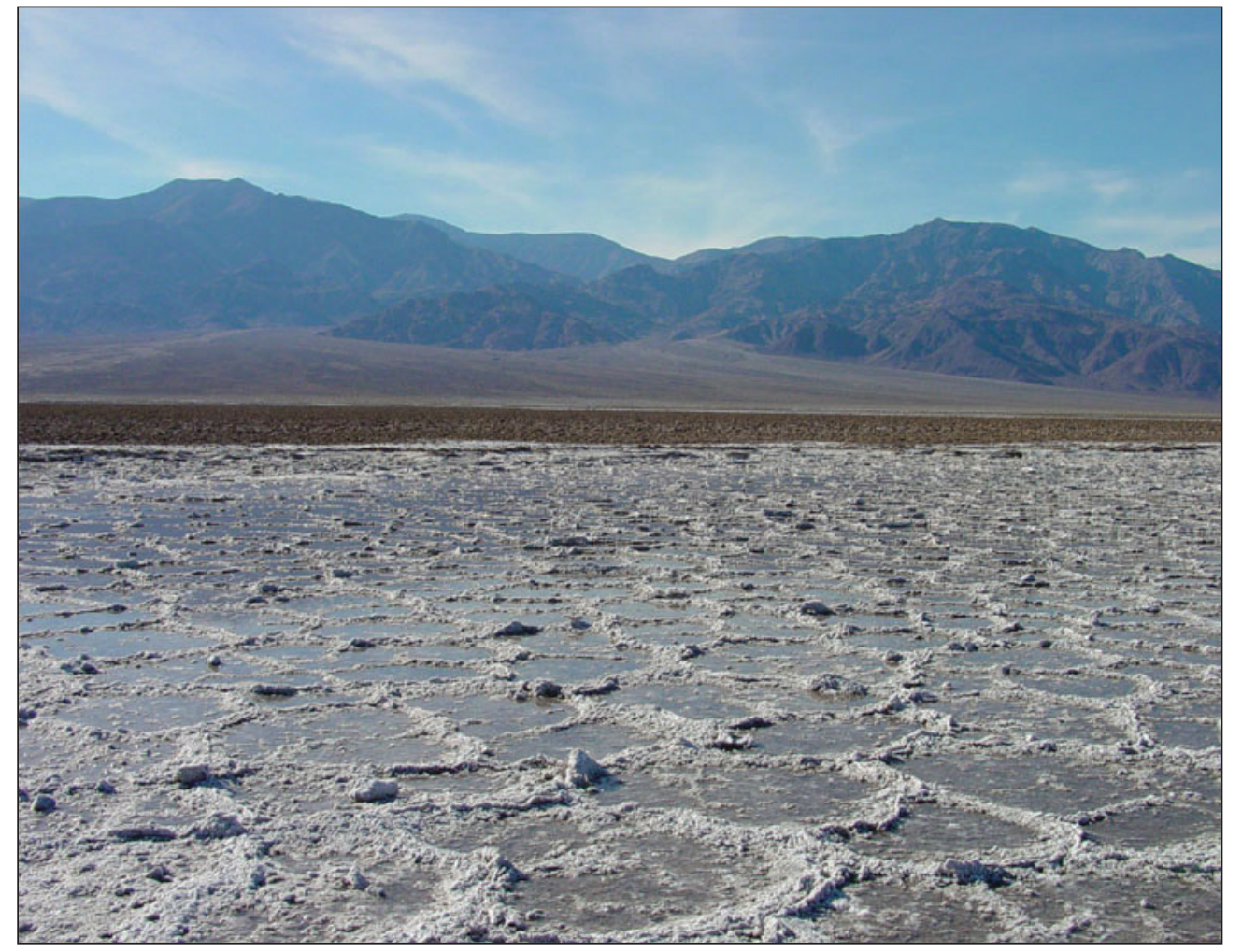

Low precipitation rates and temperatures that reach more than $120^{\circ} \mathrm{F}$ result in high potential evapotranspiration rates, such as in this area in Death Valley, California. Evapotranspiration of surface water and shallow groundwater in basin lowlands leaves behind dissolved solids and other constituents that accumulate in the basin and the underlying groundwater. 
Irrigation water often is applied to areas in the Southwest where little or no natural recharge has occurred and, as a result, can flush dissolved solids, which have accumulated in the unsaturated zone over thousands of years, down to the water table. The two highest concentrations $(65,000$ and $28,500 \mathrm{mg} / \mathrm{L})$ in shallow groundwater sampled as part of these studies in the Southwest are from the Carson Desert in Nevada. Recharge from irrigation since the early 1900s in this area has raised the shallow water table, dissolving solids concentrated in the soil.(18)

Detergents, water softeners, fertilizers, road salt, and animal and human waste contribute dissolved solids to groundwater. In arid basins with little natural recharge, septic-tank leachate, which contains elevated concentrations of dissolved solids and nitrate, can make up a large fraction of groundwater recharge. As population in these basins grows, the amount of groundwater recharge from septic tanks increases unless a sewer system is constructed. Over a 16-year period (1985-2001) in Carson Valley, Nevada, dissolved-solids concentrations increased in more than half of 27 monitoring wells sampled — concentrations were higher and increases were larger in areas where there was a greater density of septic tanks.(40) Most of the wells with upward trends in dissolved solids are near basin margins where residential developments using septic tanks are underlain by permeable basin-fill deposits. If it takes a long time for water to move through the unsaturated zone to the water table, elevated dissolved-solids concentrations in the aquifer from septic-tank leachate could continue into the future even if that source of recharge is removed.

Clay layers and upward hydraulic gradients help to protect the deeper parts of basin-fill aquifers from recharge water with high dissolved-solids concentrations, as illustrated in an irrigated agricultural area in the West Salt River Valley, Arizona. High dissolved-solids concentrations in shallow groundwater (median greater than $3,000 \mathrm{mg} / \mathrm{L}$ ) result from excess irrigation water that recharges the shallow part of the aquifer, where it is commonly pumped out and reused. The clay layer prevents the downward movement of this more mineralized water to deeper parts of the aquifer where the median dissolved-solids concentration is about $750 \mathrm{mg} / \mathrm{L}$. (38) Wells that short circuit clay layers can allow high concentrations in recharge water to reach deeper parts of the aquifer (see sidebar, Wells can "short circuit" groundwater flow paths and increase contaminant movement, p. 37). Where human modifications to natural flow systems are more substantial and (or) clay layers are not present, high dissolved-solids concentrations from recharge water can more easily reach greater aquifer depths (see sidebars, Dissolved solids have increased in groundwater used for public supply in Salt Lake Valley, Utah, p. 78, and Groundwater in California's Santa Ana Basin is managed for both quantity and quality, p. 80).
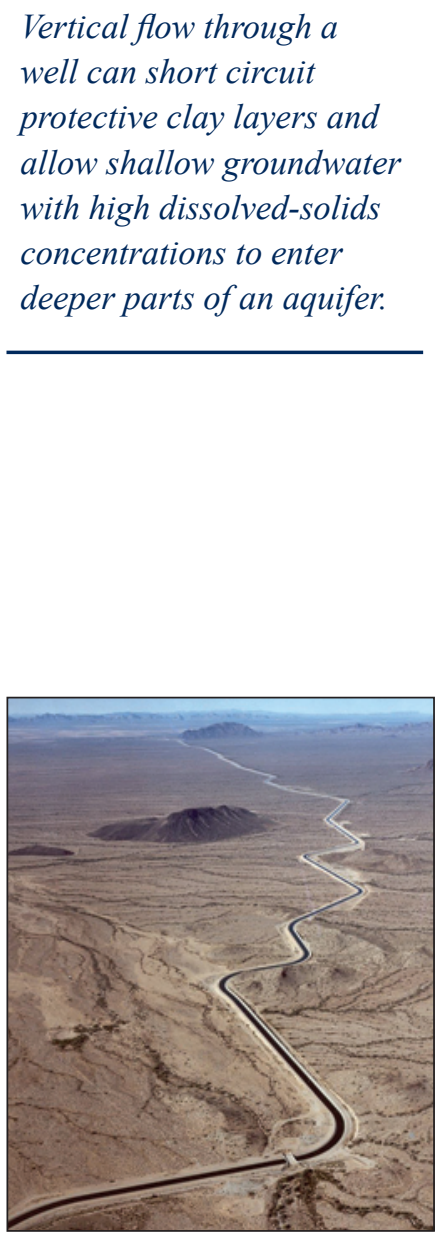

The Central Arizona Project imports Colorado River water to several Arizona basins for municipal and agricultural use. 


\section{Dissolved-solids concentrations have increased in groundwater used for public supply in Salt Lake Valley, Utah}

Dissolved-solids concentrations in deeper parts of the basin-fill aquifer used for public supply in Salt Lake Valley, Utah, typically are less than $500 \mathrm{mg} / \mathrm{L}$, but there have been substantial increases in concentrations in some areas (see sidebar figures). Increasing concentrations of dissolved solids in water from some public-supply wells likely are related to pumping, which can cause shallow groundwater to move downward by reversing the hydraulic gradient in areas where it is naturally upward. (74) Shallow groundwater also can move deeper into an aquifer along well bores, which can serve as short-circuit pathways through intervening clay layers. Because of these factors, dissolved-solids concentrations are likely to increase over time in water from wells tapping deeper parts of basin-fill aquifers, raising concerns about the potential long-term effects on groundwater suitability as a drinking-water supply.
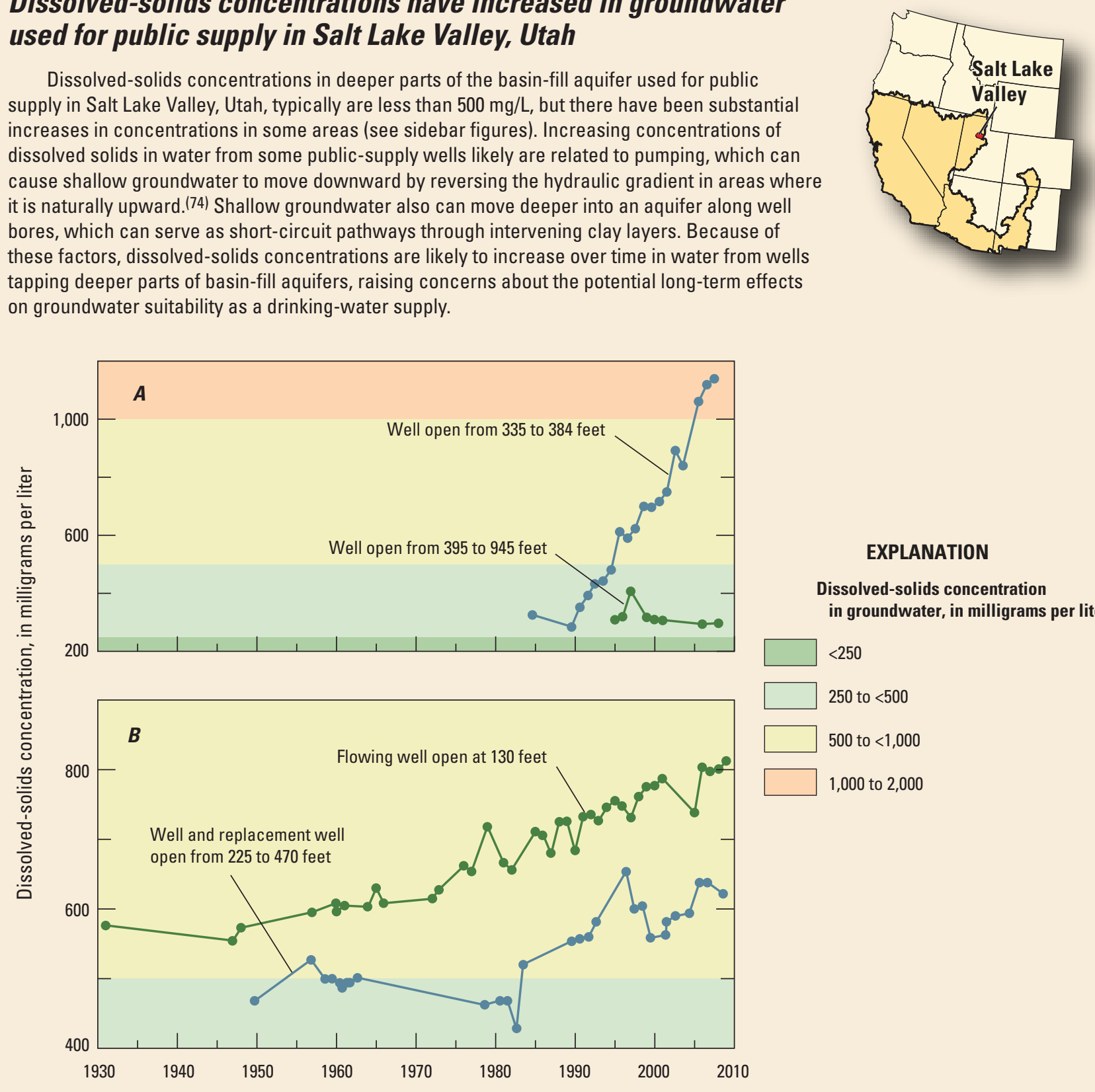

EXPLANATION

Dissolved-solids concentration in groundwater, in milligrams per liter $<250$

250 to $<500$

500 to $<1,000$

1,000 to 2,000

A, Dissolved-solids concentrations have increased in water from a public-supply well in Salt Lake Valley, Utah. Concentrations in water from a nearby well, which accesses deeper parts of the aquifer, have not changed during a similar time period. $B$, Dissolved-solids concentrations in water from two wells used for public supply in the northeastern part of the valley have increased in the past 30 years. A potential source of the dissolved solids in this area is recharge from urban runoff that contains sodium chloride (salt) used to deice roads. ${ }^{(75)}$ 
Dissolved solids in groundwater in part of Salt Lake Valley, Utah, for two time periods

\section{EXPLANATION}

Dissolved-solids concentration, in milligrams per liter

$<250$

250 to $<500$

500 to $<1,000$

1,000 to 2,000

\section{- - - - Boundary of basin-fill deposits in Salt Lake Valley}

- Well used to measure dissolved solids in part of aquifer used for public supply

\section{8-1992}
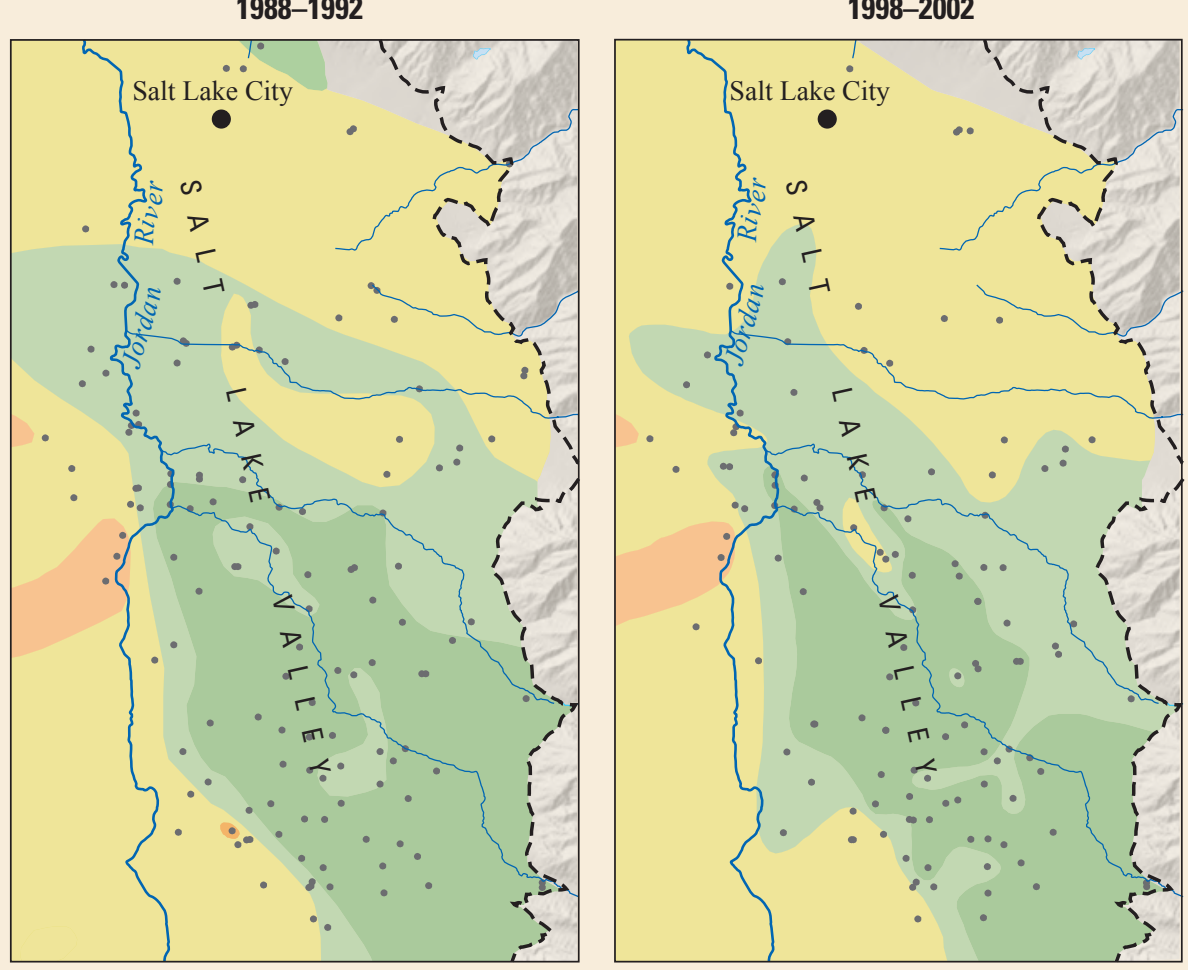

The spatial distribution of dissolved solids in the deeper part of the basin-fill aquifer used for public supply in Salt Lake Valley, Utah, has changed over time. A larger area now has concentrations of dissolved solids greater than the SMCL of $500 \mathrm{mg} / \mathrm{L}$ (yellow areas), particularly in the northeastern part of the valley.

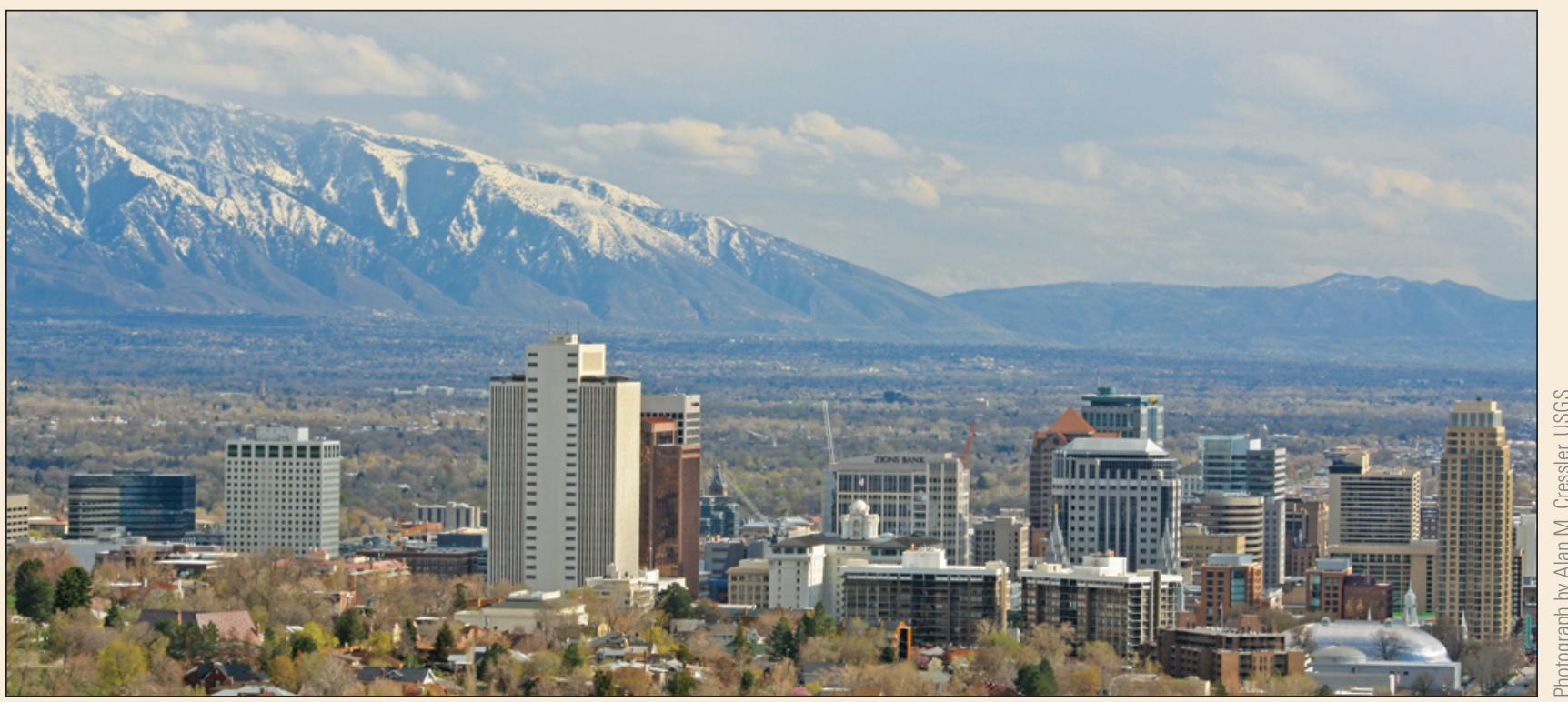

Salt Lake City and Salt Lake Valley, Utah, looking southeast. 


\section{Groundwater in California's Santa Ana Basin is managed for both quantity and quality}

Groundwater is a critical resource in the Santa Ana Basin, supplying about 1 billion gallons per day or two-thirds of the water used by the 5 million people who live there. (76) In parts of the basin, however, concentrations of dissolved solids in groundwater are greater than $1,000 \mathrm{mg} / \mathrm{L}$ (see figure below). More than 100 years of irrigated agriculture and more recent human-related sources of dissolved solids, combined with evaporative concentration and other natural sources, contribute to these high concentrations. Many aspects of the hydrologic system now are managed - through artificial recharge, desalination, high-level wastewater treatment, and saltwater intrusion barrier wells- to ensure that there is enough good-quality groundwater to supply the population's water needs.

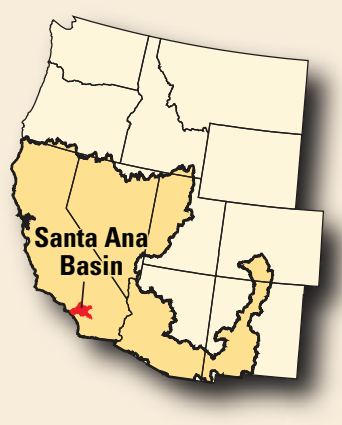

Dissolved solids in groundwater and engineered recharge facilities in the Santa Ana Basin, California

EXPLANATION

Dissolved-solids concentration,

in milligrams per liter

$<250$

250 to $<500$

500 to $<1,000$

1,000 to $<3,000$

3,000 to 25,000

- Engineered recharge facility

○ Wastewater-treatment plant

Approximate direction of groundwater flow

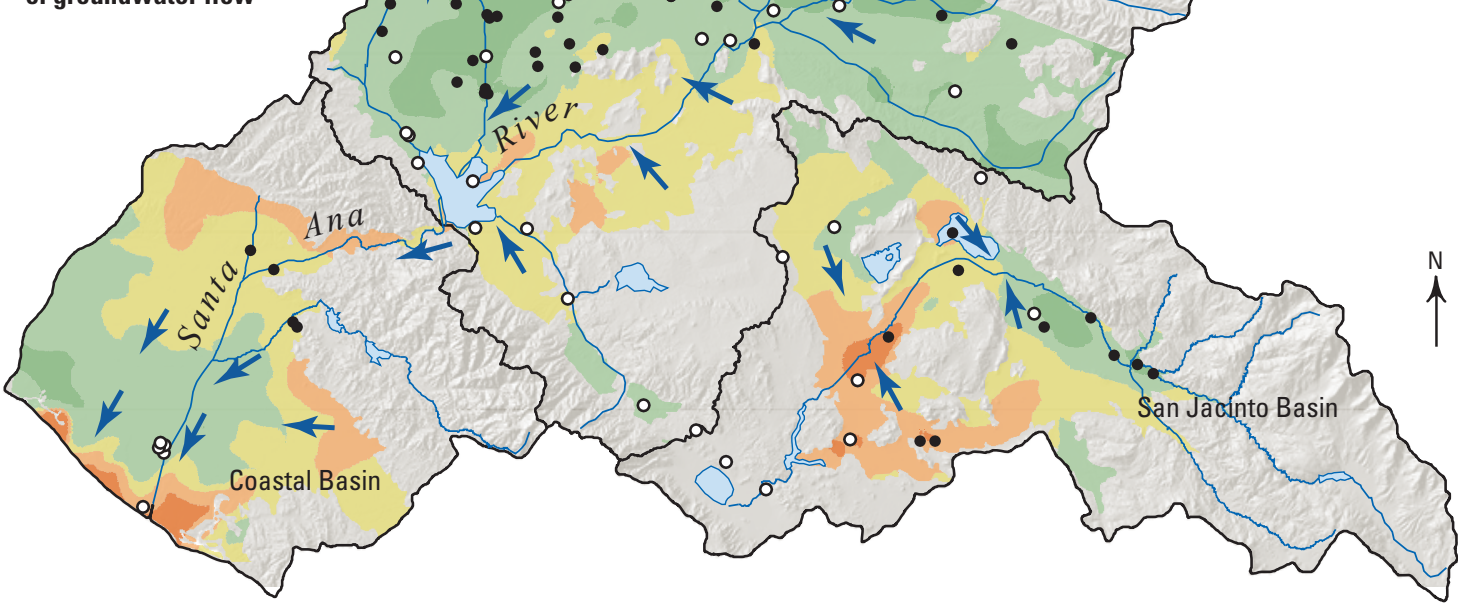

Data from Wildermuth Environmental, Inc., appendix $8^{(80)}$

Dissolved-solids concentrations in basin-fill aquifers of the Santa Ana Basin, California, range from less than $250 \mathrm{mg} / \mathrm{L}$ where the aquifers receive recharge from mountainous areas to greater than $3,000 \mathrm{mg} / \mathrm{L}$ in areas where evapotranspiration, weathering of soluble marine rocks, and intrusion of ocean water caused by well pumping occurs. Engineered recharge facilities are used to replenish the aquifer, some of which recharge water with higher dissolved-solids concentrations than the mountain runoff. 
Much of the runoff from the mountains that rise steeply along the northern sides of the Santa Ana Basin naturally recharges the basin-fill aquifers. To increase the volume of groundwater recharge in the San Jacinto and Inland Basin parts of the Santa Ana Basin, engineered recharge facilities are used to move stormwater runoff from within the basin and treated municipal wastewater-sources that typically have higher dissolved-solids concentrations than the mountain recharge-to the aquifers.

In the Coastal Basin (the furthest downgradient part of the Santa Ana Basin), engineered groundwater recharge facilities capture much of the flow in the Santa Ana River and use it to recharge the basin-fill aquifer. As the river enters the Coastal Basin from the Inland Basin, its flow includes treated municipal wastewater, intermittent stormwater runoff from agricultural and urban land, and discharge of groundwater that has been affected by human activities. ${ }^{(76)}$ Because the Santa Ana River is the source of almost all of the recharge to the aquifer in the Coastal Basin, sources of dissolved solids to the river water must be managed so that groundwater supplies in the Coastal Basin remain potable. For example, wells and desalination plants in the downstream part of the Inland Basin are used to reduce the volume of groundwater with high dissolved-solids concentrations that discharges to the river; these wells also provide potable water to residents of the Inland Basin (see sidebar photograph). Recently (since 2008), water from a state-of-the art advanced wastewater-treatment facility in the Coastal Basin, which reduces total dissolved solids in the effluent to less than $100 \mathrm{mg} / \mathrm{L}$, also is being used to recharge the aquifer at facilities near the Santa Ana River. This facility is the largest water purification project of its kind in the world and cost \$480 million to build. (77) A \$143 million expansion at the facility is scheduled for completion in 2014.

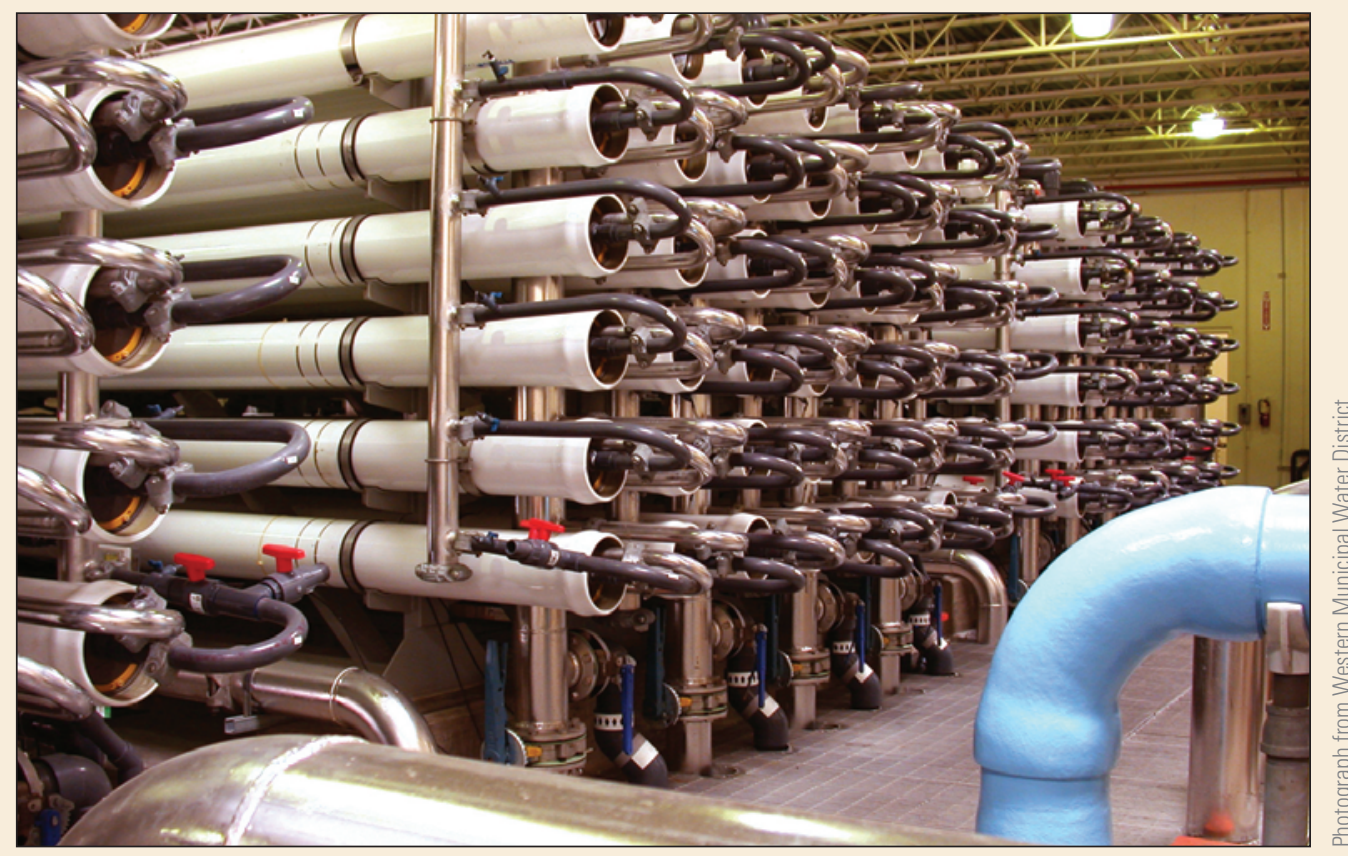

Groundwater in parts of the Santa Ana Basin in southern California is treated to reduce dissolved-solids concentrations so that the groundwater can be used for water supply and to improve the quality of groundwater that discharges into the Santa Ana River. 


\section{Potential Actions That Can Provide Acceptable Concentrations of Dissolved Solids in Groundwater Used for Drinking Water}

Concentrations of dissolved solids in the deep parts of basin-fill aquifers in Southwest basins with land and water development are likely to increase as a result of increased groundwater flow rates, mixing within aquifers, and loading of the aquifers with dissolved solids. Some of the options available to water suppliers to provide water with acceptable concentrations of dissolved solids are:

- Blending with other water that contains lower concentrations of dissolved solids, if available;

- Treatment to remove dissolved solids (desalination, typically with reverse osmosis, is required);

- Seeking alternative sources of water that are suitable for drinking, such as imported water;

- Sealing off well openings in zones of poor quality water; and

- Deepening existing wells or drilling additional wells in areas unaffected by elevated concentrations.

All of these actions have associated costs. The purchase and installation of a household reverse osmosis under-the-sink system can cost a homeowner a few hundred to a few thousand dollars. Construction of a water-treatment facility capable of treating several million gallons per day can cost tens of millions of dollars, and there are additional, ongoing costs for energy and maintenance and for disposal of the residual brine. Because water supplies in the Southwest are limited, it can be more cost effective to prevent degradation of potable water supplies than to seek new sources of water. In Salt Lake Valley, Utah, the State engineer has implemented a groundwater-management plan that places limits on pumping to prevent water-quality degradation caused by the movement of groundwater with elevated dissolved-solids concentrations. In southern California, residents are being informed about increases in dissolved solids caused by water softeners and the effect it has on their recycled (treated wastewater) water supply.(45) 


\section{Volatile Organic Compounds and Pesticides}

Volatile organic compounds (VOCs), pesticides, or pesticide degradates were detected in 57 percent of drinking-water wells tapping Southwest basin-fill aquifers, but concentrations rarely approached levels of concern for human health. The frequent presence of these contaminants at low concentrations beneath agricultural and urban settings indicates that groundwater in many areas of the Southwest is vulnerable to contamination caused by human activities. Several organic compounds are persistent under environmental conditions common in basin-fill aquifers, and the contaminants likely will be transported through the aquifer system for many years.

VOCs and pesticides are released to the environment by human activities. VOCs include many common chemicals - solvents, gasoline components, refrigerants - that are used for a variety of purposes in industry, commerce, households, and occasionally agriculture. Pesticides are chemicals used in agricultural and urban settings to control weeds, insects, and other pests. The occurrence of VOCs and pesticides in Southwest basin-fill aquifers (appendix 2, table A2-3) demonstrates that these aquifers are vulnerable to contamination from the land surface.

Human-health benchmarks (see sidebar, Human-health benchmarks and other guidelines used in this assessment, p. 43) have been established for several VOCs and pesticides in drinking water. Many potential human-health effects are related to exposure to VOCs or pesticides, including increased risk of cancer and effects on the nervous, immune, circulatory, and reproductive systems. Most human-health benchmarks for individual chemicals are higher than $0.2 \mu \mathrm{g} / \mathrm{L}$, or part per billion, whereas laboratory methods used by the NAWQA Program typically can detect VOCs and pesticides in water at concentrations as much as 100 times smaller. Groundwater commonly contains more than one chemical, but little is known about the potential health effects of most mixtures of contaminants in drinking water-it is possible that the toxicity of the mixture may be greater than that of any single VOC or pesticide compound present.

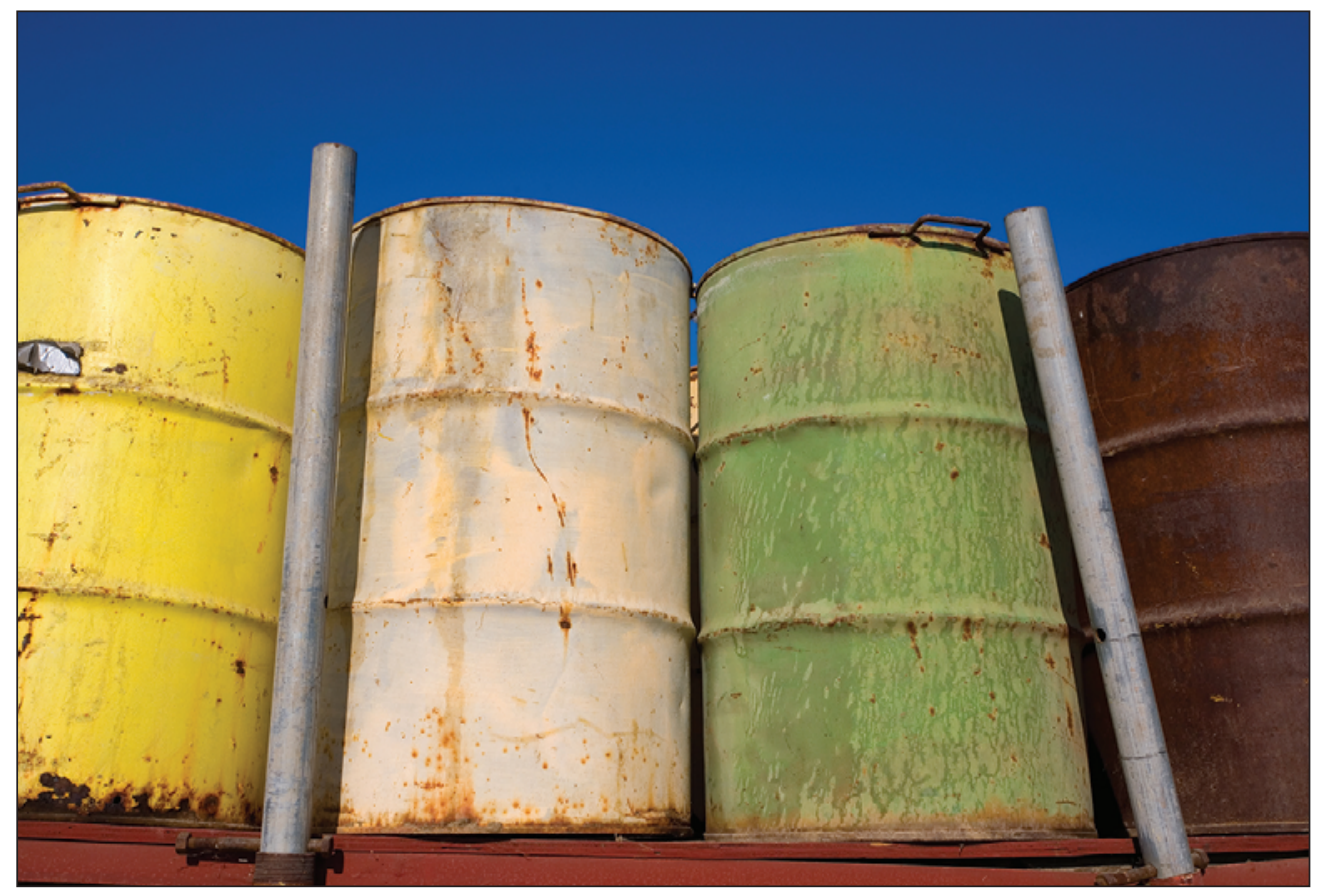

Volatile organic compounds and pesticides are manmade chemicals used at the land surface that can be transported to groundwater. A potential source is illustrated by corroded barrels that might have stored chemicals. 
VOCs detected in publicsupply wells reflect the chemicals used in urban areas.

\section{VOCs Were Detected Primarily in Groundwater From Urban Settings, Typically at Concentrations Substantially Below Human-Health Benchmarks}

Although at least one VOC was detected in water from 43 percent of all wells sampled in Southwest basin-fill aquifers, concentrations generally were low. VOCs were detected most commonly in shallow groundwater in urban settings and in samples from public-supply wells, which tend to be located in urban areas (fig. 6-21). Most VOCs are associated primarily with urban sources - for example, chlorinated water, gas stations, dry cleaners, metals shops, and many industrial processes. Only 10 of the more than 80 VOCs included in the analysis of groundwater samples accounted for most detections, especially among drinking-water (domestic and public-supply) wells (fig. 6-21). In particular, only the trihalomethanes chloroform and bromodichloromethane (see sidebar, Common VOCs and their uses, p. 86) and the solvents perchloroethene (PCE) and trichloroethene (TCE) were detected in more than 10 percent of public-supply wells. PCE and TCE each were detected in two drinking-water wells at a concentration that exceeded their MCLs, but concentrations exceeded one-tenth of the MCL in fewer than 2 percent of drinking-water wells (table 5-1). Concentrations of the fumigant dibromochloropropane (DBCP) exceeded its MCL in 16 domestic wells in the eastern San Joaquin Valley, California. The history of the use and movement of DBCP through the aquifer is described in more detail later in this section. Mixtures of two or more VOCs were detected in 22 percent of drinking-water wells, and mixtures of four or more VOCs were detected in 4.7 percent of drinking-water wells.

Chloroform, a trihalomethane, was the VOC most commonly detected in Southwest basin-fill aquifers and in groundwater sampled nationwide as part of the NAWQA Program.(16) A common source of trihalomethanes to groundwater is chlorinated water used to irrigate urban landscaping (including lawns and parks) as well as leaks from drinking-water distribution and sewer pipes (fig. 6-1B). The number of detections of chloroform in shallow urban groundwater in the Southwest increased with the number of households connected to public sewers. (37) Households connected to public sewers commonly also are connected to chlorinated public water-supply systems.

Releases of PCE, TCE, and MTBE (methyl tert-butyl ether-a gasoline oxygenate) typically occur where solvents or gasoline have been stored, spilled, or improperly disposed. In shallow urban groundwater in the Southwest, PCE, TCE, and MTBE were commonly detected in areas with industrial land use.(37)
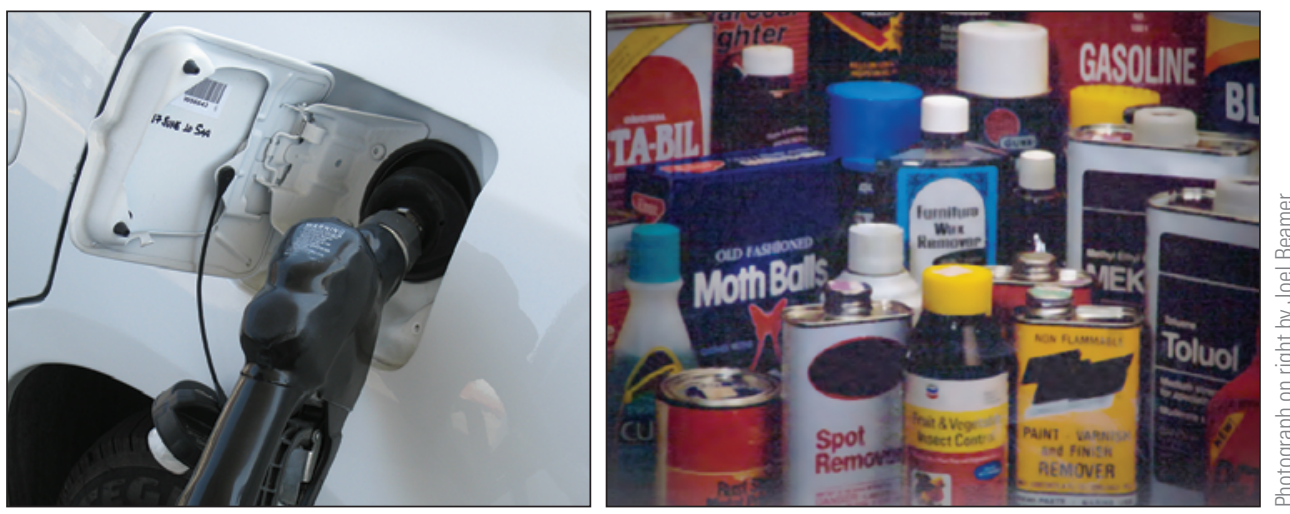

Gasoline contains VOCs that can be released to groundwater from leaking storage tanks at facilities where vehicles are fueled. VOCs present in common household, commercial, and industrial products can reach groundwater as a result of spills or improper disposal. 
Detection frequency of VOCs in groundwater
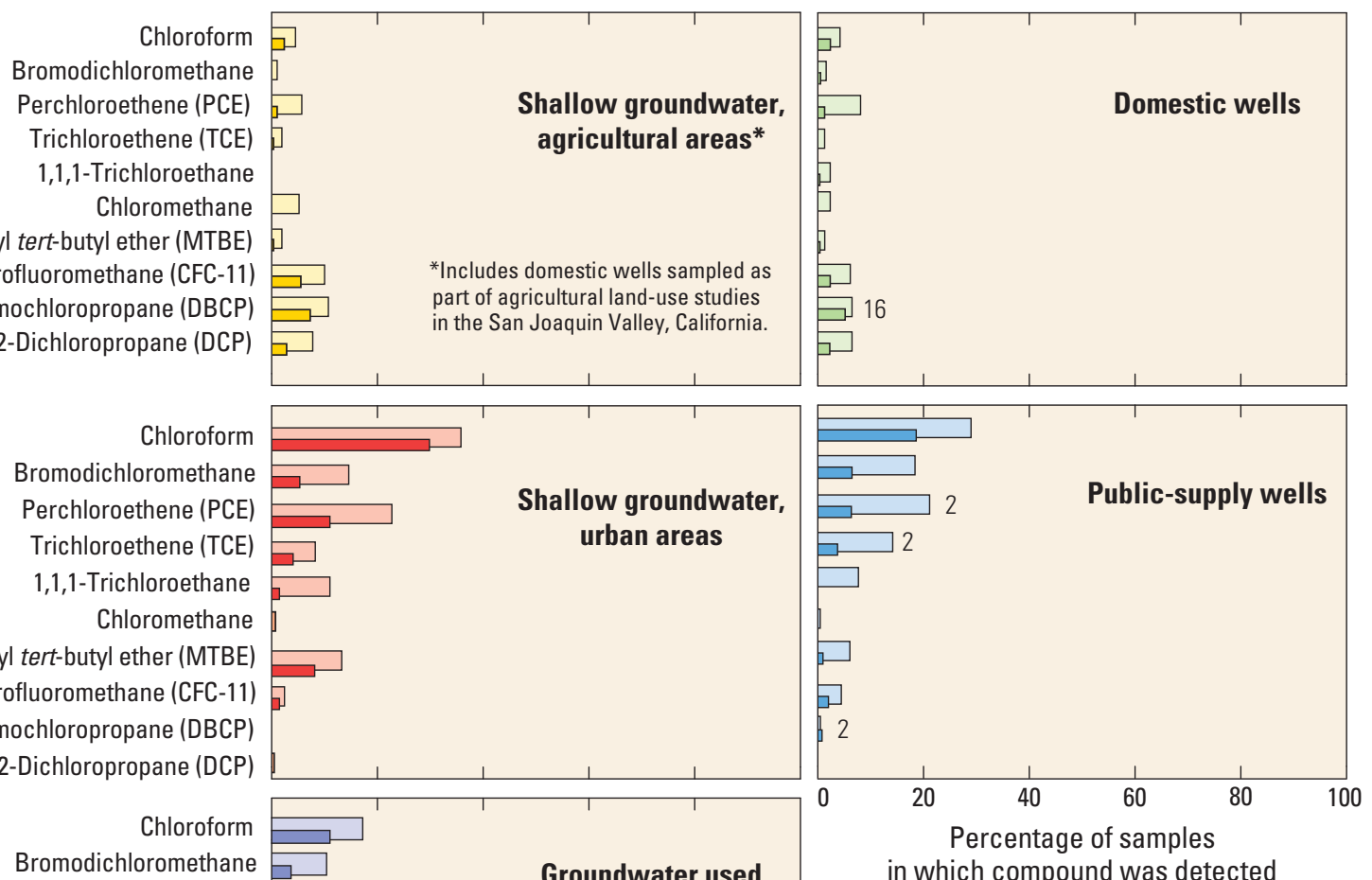

Bromodichloromethane Perchloroethene (PCE)

Trichloroethene (TCE)

1,1,1-Trichloroethane Chloromethane

Bromodichloromethane

Perchloroethene (PCE)

Trichloroethene (TCE)

1,1,1-Trichloroethane

Chloromethane

Methyl tert-butyl ether (MTBE)

Trichlorofluoromethane (CFC-11)

Dibromochloropropane (DBCP)

1,2-Dichloropropane (DCP)

Chloroform

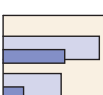

1

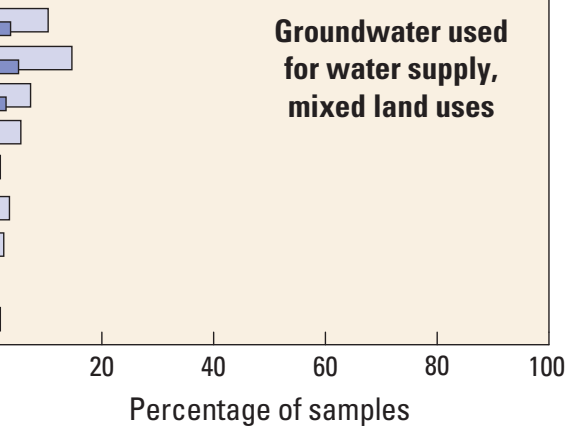

in which compound was detected
Shallow groundwater, urban areas

in which compound was detected

\section{EXPLANATION}

Concentration of VOCs,

in micrograms per liter

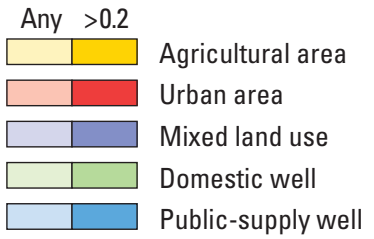

2 Number of exceedances of human-health benchmarks listed for drinking-water wells

Figure 6-21. VOCs were detected more frequently in shallow groundwater in urban areas and in public-supply wells, which tend to be located in urban areas, than in shallow groundwater in agricultural areas or in domestic wells, which tend to be located in rural areas. These detections reflect the more common use of VOCs in urban areas. Note that because the lowest detectable concentration differs among compounds, detection frequency is shown for any concentration and for a common assessment level of $0.2 \mu \mathrm{g} / \mathrm{L}$. 


\section{Common VOCs and their uses}

The VOCs most commonly detected in Southwest groundwater (fig. 6-21) fall into five categories: trihalomethanes, solvents, gasoline oxygenates, refrigerants, and fumigants as shown in the table below. Many VOCs are included in more than one category. For example, chloroform is a trihalomethane and a solvent. Under the right environmental conditions, some VOCs can degrade to form other VOCs (degradates)-PCE, for example, can degrade to form TCE. More details on the uses of individual VOCs can be found in appendix 4 of Zogorski and others. ${ }^{(16)}$

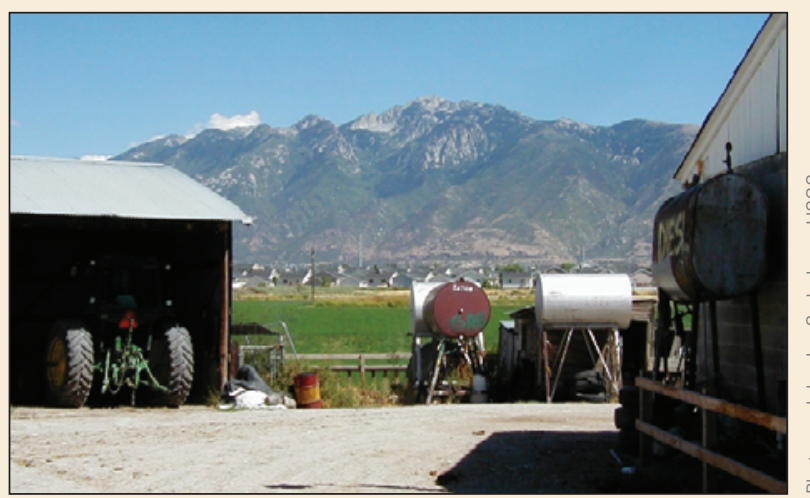

Farm in Salt Lake Valley, Utah, with above-ground storage tanks.

The VOCs most commonly detected in Southwest groundwater have diverse uses.

\begin{tabular}{|l|l|l|}
\hline \multicolumn{1}{|c|}{ VOCs most commonly detected } & \multicolumn{1}{|c|}{ Category of VOCs } & \multicolumn{1}{c|}{ Source or uses } \\
\hline Chloroform, bromodichloromethane & Trihalomethanes & $\begin{array}{l}\text { Commonly produced during chlorination of } \\
\text { drinking water and wastewater through the } \\
\text { reaction of chlorine and organic material. }\end{array}$ \\
\hline $\begin{array}{c}\text { Perchloroethene (PCE), trichlorethene (TCE), } \\
1,1,1 \text {-trichloroethane, chloromethane }\end{array}$ & Solvents & $\begin{array}{l}\text { Used for many industrial, commercial, and } \\
\text { household applications, including manufac- } \\
\text { turing and degreasing. }\end{array}$ \\
\hline Methyl tert-butyl ether (MTBE) & Gasoline oxygenates & $\begin{array}{c}\text { Added to gasoline to improve combustion and } \\
\text { reduce harmful motor vehicle emissions. }\end{array}$ \\
\hline Trichlorofluoromethane (CFC-11) & Refrigerants & $\begin{array}{l}\text { Used as a heat transport medium in refrigerators } \\
\text { and air cooling systems. }\end{array}$ \\
\hline $\begin{array}{l}\text { Dibromochloropropane (DBCP), } \\
1,2 \text {-dichloropropane (DCP) }\end{array}$ & Fumigants & $\begin{array}{c}\text { Used to destroy, repel, or control organisms such } \\
\text { as insects, bacteria, or rodents, and are also } \\
\text { considered pesticides. }\end{array}$ \\
\hline
\end{tabular}




\section{Pesticide Compounds Detected in Groundwater From Agricultural and Urban Settings Were Typically at Concentrations Substantially Below Human-Health Benchmarks}

Although at least one pesticide compound (parent or degradate) was detected in water from nearly half (45 percent) of all wells sampled in Southwest basin-fill aquifers, concentrations generally were low. As a group, pesticide compounds were detected with similar frequencies in shallow monitoring wells, domestic wells, and public-supply wells in agricultural and urban areas, reflecting the use of pesticides in both agricultural and urban areas. Because of their pattern of use, however, some individual compounds were more commonly detected in one or the other setting (fig. 6-22). Most detections in groundwater, especially in drinking-water wells, were for just a few pesticide compounds. In particular, only four pesticide compounds - simazine, atrazine, and the atrazine degradates deethylatrazine and deisopropyl atrazine - were detected in more than 10 percent of domestic and public-supply wells (fig. 6-22). Dieldrin is an insecticide that was used in the past for agricultural and urban uses, but has been banned because of risks to human health. Although not among the most commonly detected pesticide compounds, dieldrin was the only pesticide compound detected in drinking-water wells at a concentration that exceeded its humanhealth benchmark of $0.002 \mu \mathrm{g} / \mathrm{L}$ ( 5 of 560 public-supply and domestic wells) (table 5-1).

\begin{tabular}{l}
\hline Pesticides were detected \\
with similar frequencies \\
in shallow groundwater \\
in urban and agricultural \\
areas and in domestic \\
and public-supply wells, \\
which reflects pesticide \\
use in both urban and \\
agricultural settings.
\end{tabular}

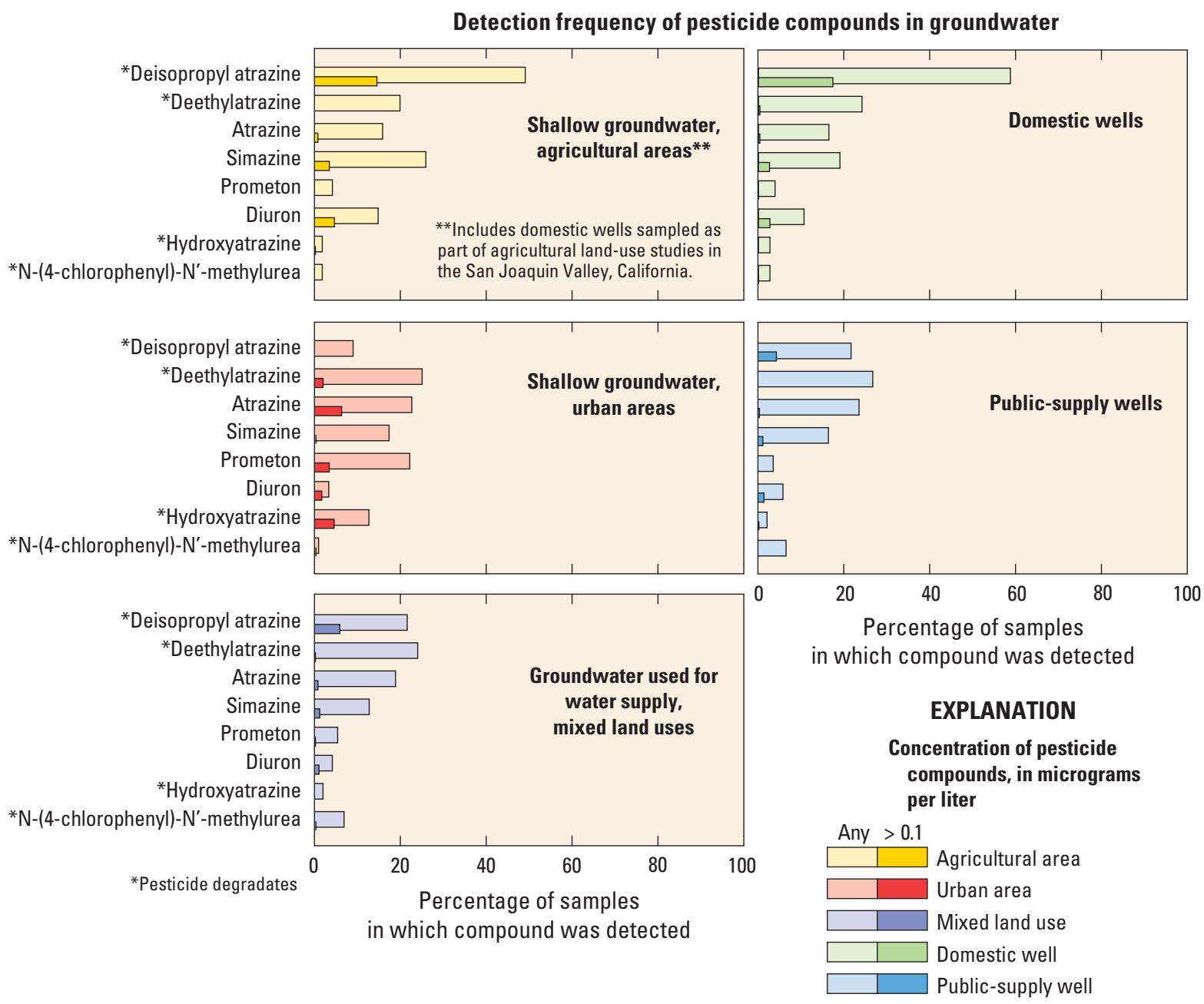

Figure 6-22. Pesticide compounds were detected in similar percentages of samples of shallow groundwater in agricultural and urban areas and in domestic and public-supply wells, reflecting use of pesticides in both agricultural and urban areas. Note that because the lowest detectable concentration differs among compounds, detection frequency is shown for any concentration and for a common assessment level of $0.1 \mu \mathrm{g} / \mathrm{L}$. 
Mixtures of two or more pesticide compounds were detected in 28 percent of drinking-water wells, and mixtures of four or more pesticide compounds were detected in 10 percent of drinking-water wells. Toxicity data for mixtures of pesticide compounds are seldom available. Information on the occurrence and composition of mixtures can help to characterize the potential exposure of humans, aquatic life, and wildlife to mixtures and make it possible to prioritize mixtures that may occur in groundwater for further study.(46)

The herbicide atrazine (see sidebar, Common pesticides and their uses, p. 89) was the most commonly detected pesticide in Southwest basin-fill aquifers and also in groundwater sampled nationwide as part of the NAWQA Program.(46) In the Southwest, the atrazine degradates deethylatrazine and deisopropyl atrazine were detected even more commonly in groundwater than their parent compound. Although atrazine was detected in groundwater in both agricultural and nonagricultural areas in several study basins, presumably because of its application for weed control in both types of settings, the herbicide and its degradates deethylatrazine and hydroxyatrazine were detected more often in shallow groundwater in urban settings than in agricultural settings (fig. 6-22). The use of atrazine in agricultural areas is not as common in the Southwest as it is in other parts of the United States, especially in the Corn Belt of the Midwest where application rates are high.(47)

Similar to atrazine, broad patterns in the use of the herbicides simazine and prometon affected their detection frequencies. Simazine commonly is used for both agricultural and nonagricultural purposes (such as weed control near buildings and along roads) and was detected about as commonly in shallow urban groundwater as in shallow agricultural groundwater. Prometon, in contrast, is used by homeowners to control weeds and is not used on crops. It was detected about four times more commonly in shallow urban groundwater than in shallow agricultural groundwater (fig. 6-22).

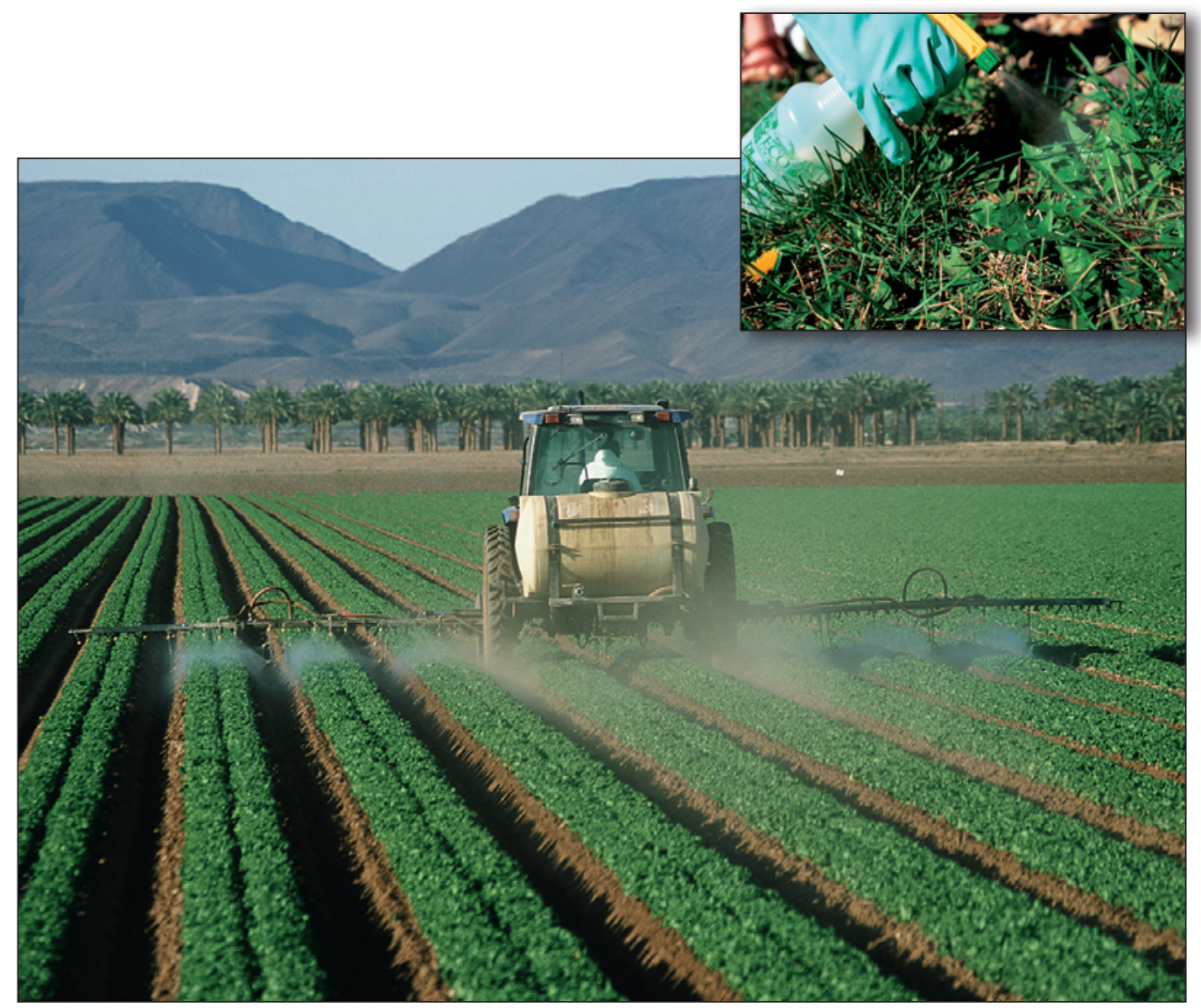

Photographs: Left, Jeff Vanuga, Natural Resource Conservation Service, U.S. Department of Agriculture; top right, Lynn Betts, Natural Resource Conservation Service, U.S. Department of Agriculture

Pesticides are used on crops in agricultural settings (lettuce crop in Yuma, Arizona, left) and also on golf courses, yards, and other areas in urban settings (top). 


\section{Common pesticides and their uses}

Herbicides and their degradates were detected more commonly in basin-fill aquifers than were other types of pesticides. Degradates are compounds formed by the degradation (breakdown) of a "parent" compound. In groundwater, the concentration of a degradate sometimes exceeds the concentration of the parent compound, and some degradates are more toxic than their parent compound. Degradates were analyzed as part of the NAWQA Program for only a relatively small number of pesticides. Details on the use and properties of individual pesticide compounds can be found in appendixes 1 and 2 of Gilliom and others. (46)

Herbicides and herbicide degradates were detected more commonly in Southwest groundwater than were other types of pesticides.

\begin{tabular}{|c|c|c|}
\hline $\begin{array}{l}\text { Pesticide compounds most } \\
\text { commonly detected }\end{array}$ & $\begin{array}{l}\text { Category of pesticide } \\
\text { compounds }\end{array}$ & Source or uses \\
\hline Atrazine & Herbicide & $\begin{array}{l}\text { Used to control unwanted plants in mostly agricultural } \\
\text { areas. Also used for nonagricultural purposes, such } \\
\text { as to control roadside vegetation. }\end{array}$ \\
\hline Diuron & Herbicide & $\begin{array}{l}\text { Used to control unwanted plants in urban areas, such } \\
\text { as along roadsides. }\end{array}$ \\
\hline Prometon & Herbicide & Used by homeowners to control weeds. \\
\hline Simazine & Herbicide & $\begin{array}{l}\text { Used to control unwanted plants in agricultural and } \\
\text { urban areas. }\end{array}$ \\
\hline $\begin{array}{l}\text { Deethylatrazine, deisopropyl atrazine, and } \\
\text { hydroxyatrazine }\end{array}$ & Herbicide degradates & Degradates of atrazine. \\
\hline N-(4-chlorophenyl)-N'-methylurea & Herbicide degradate & $\begin{array}{l}\text { Degradate of monuron, an herbicide used in } \\
\text { urban areas. }\end{array}$ \\
\hline
\end{tabular}

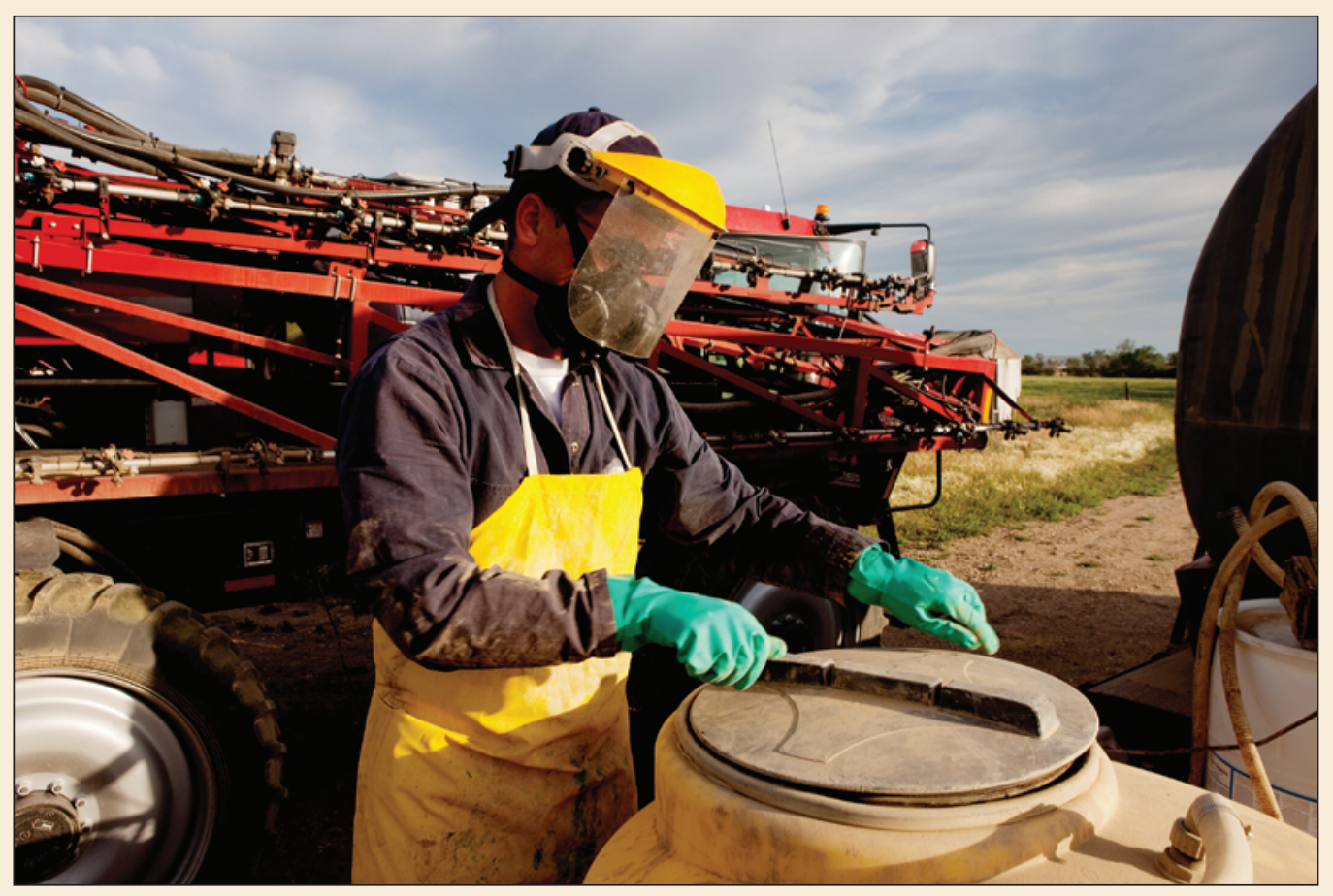

Pesticides are sprayed on some agricultural fields to control unwanted plants or pests. 


\section{Environmental Conditions Affect the Persistence of VOCs and Pesticides}

Many organic compounds degrade to some degree within the soil zone before they reach the groundwater. Some compounds volatilize into air or adhere to soil particles or organic matter, further decreasing the amount of the compound that reaches the water table. Such compounds are less likely to be detected in groundwater than are more persistent and less volatile or soluble compounds. In some instances, persistence can be more important to detection than the volume of a compound used (fig. 6-23).

Much of the groundwater in Southwest basin-fill aquifers contains dissolved oxygen (is oxic), which affects the persistence of many organic compounds in groundwater (see section Geochemical Conditions Are Important Controls on Contaminant Transport in chapter 4). Some VOCs, such as chloroform and PCE, degrade less readily under oxic conditions than under anoxic conditions.(16) In shallow groundwater in urban areas - the setting in which chloroform(37) was most commonly detected (fig. 6-24) — chloroform was detected about eight times more frequently in samples of oxic groundwater than in samples of anoxic groundwater. Other VOCs, however, degrade relatively rapidly under oxic conditions. For example, the gasoline compounds benzene and toluene are used intensively and widely on a national scale,(16) but were detected in less than 4 percent of Southwest wells.

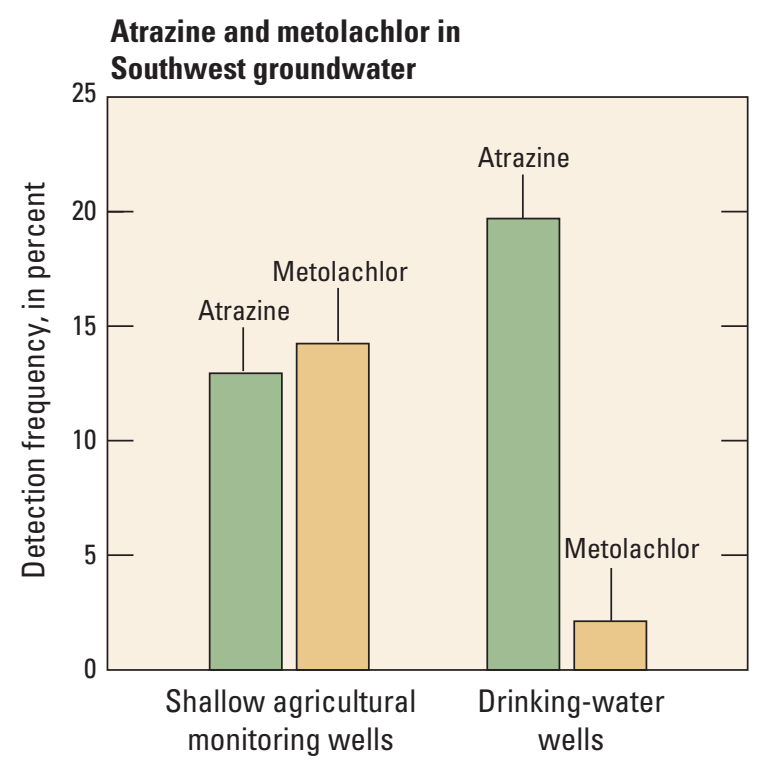

Figure 6-23. Although metolachlor use in agricultural areas of the Southwest (1992-2002) was several times higher than atrazine use, the two herbicides were detected in a similar percentage of shallow, agricultural monitoring wells. This apparent contradiction is because metolachlor breaks down much more rapidly in soil and water than does atrazine. The greater persistence of atrazine in soil and water corresponds with its being detected about 10 times more frequently than metolachlor in deeper domestic and public-supply wells.

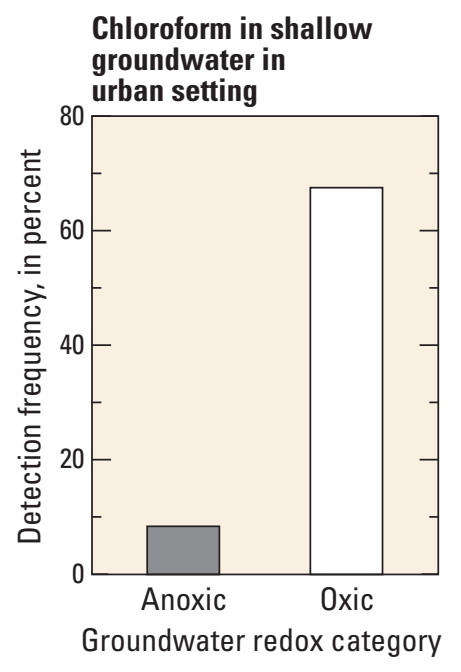

Figure 6-24. In wells in urban areas, chloroform was more frequently detected in shallow groundwater with oxic conditions than in shallow groundwater with anoxic conditions, because chloroform does not degrade readily in oxic groundwater. 


\section{VOCs and Pesticides in Public-Supply Wells Indicate Aquifer Vulnerability to Contamination}

Land and water development in Southwest basins increases the vulnerability of deep groundwater to contamination by VOCs and pesticides (fig. 6-1B). Activities associated with agricultural and urban land uses introduce potential sources of VOCs and pesticides. Increased recharge from irrigation enhances the transport of these compounds to the water table and through the aquifer. The downward migration to depths used for drinking-water supply can be further enhanced by water-level declines that result from the pumping of deep groundwater by water-supply wells and (or) by preferential movement of groundwater directly down wells from shallow to deeper depths (see sidebar, Wells can "short circuit" groundwater flow paths and increase contaminant movement, p. 37).

The combined effect of more contaminant sources, increased recharge, groundwater pumping, and preferential flow on downward migration of VOCs and pesticides increases with more development. In highly developed basins, these stresses eventually can counteract the protective effects of naturally upward groundwater flow and (or) confining layers, thereby increasing the vulnerability of deeper parts of aquifers to contamination. Because changes to the quality of shallow groundwater generally are evident more quickly, detections of these compounds at shallow depths provide an early indication that, over time, the deeper groundwater used for drinking-water supply might be affected.

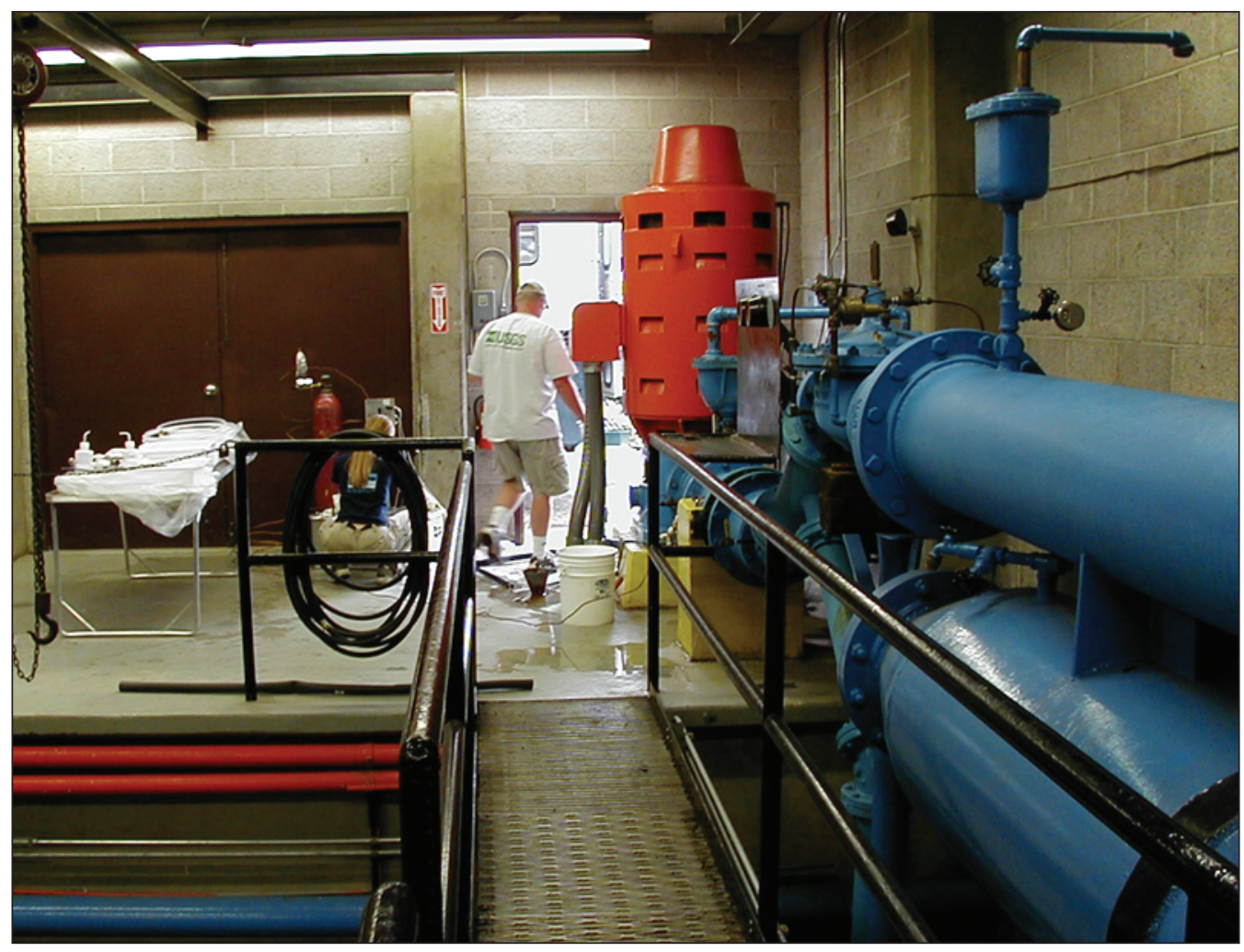

Land and water development in Southwest basins increases the vulnerability of deep groundwater to contamination by VOCs and pesticides.

Public-supply wells, such as this one being sampled in Salt Lake Valley, Utah, can pump large volumes of water from the basin-fill aquifer. 


\section{Detections of compounds in young groundwater reflect the local history of chemical use in the eastern San Joaquin Valley, California}

Intensive farming in the eastern San Joaquin Valley is coupled with rapid population growth. The occurrence of DBCP at concentrations exceeding its MCL of $0.2 \mu \mathrm{g} / \mathrm{L}$ in domestic wells is a human-health concern in this area. Elevated concentrations of nitrate in groundwater also are of concern, as described in the nitrate section of this chapter.

Local groundwater quality reflects patterns in the use of the soil fumigant DBCP and the herbicide simazine in this area over the past several decades.(39) DBCP use began in the 1950s for control of nematodes, primarily in orchards and vineyards. Its use increased until 1977, when agricultural use of DBCP was banned because of human-health concerns. The ban is reflected in the differences in concentrations in groundwater from domestic and monitoring wells. DBCP was detected more commonly and at higher concentrations in groundwater from domestic wells - water that typically recharged around 1980 - than in monitoring wells, which are shallower and therefore typically tap groundwater that recharged around 1990. Concentrations were low in public-supply wells, which typically are deeper than either domestic wells or monitoring wells and therefore tap water that recharged before DBCP was in use.

Simazine use for agricultural and nonagricultural weed control also began in the late 1950s, and simazine still is commonly used. The increase in simazine concentrations in groundwater over time reflects its increasing use. Concentrations are highest in shallow groundwater that recharged in about 1990 and decrease with depth.

DBCP continues to be detected in groundwater decades after its agricultural use was banned. Because of the persistence of DBCP and simazine in groundwater and the downward movement of groundwater in the eastern San Joaquin Valley, concentrations of these pesticides in water from public-supply wells are likely to increase.(39)

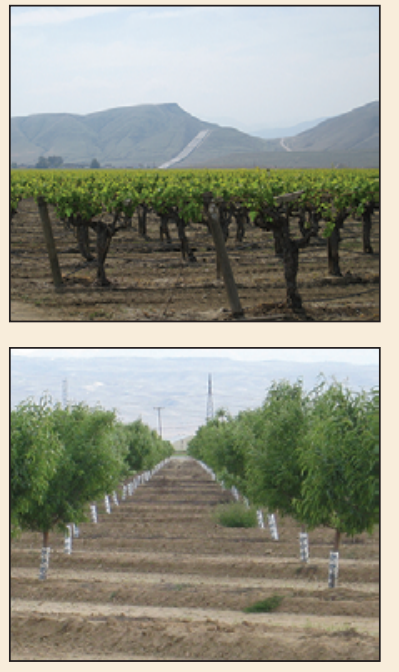

The pesticides dibromochloropropane (DBCP) and simazine historically have been applied to orchards and vineyards in the eastern San Joaquin Valley, California, and have been detected in local groundwater.

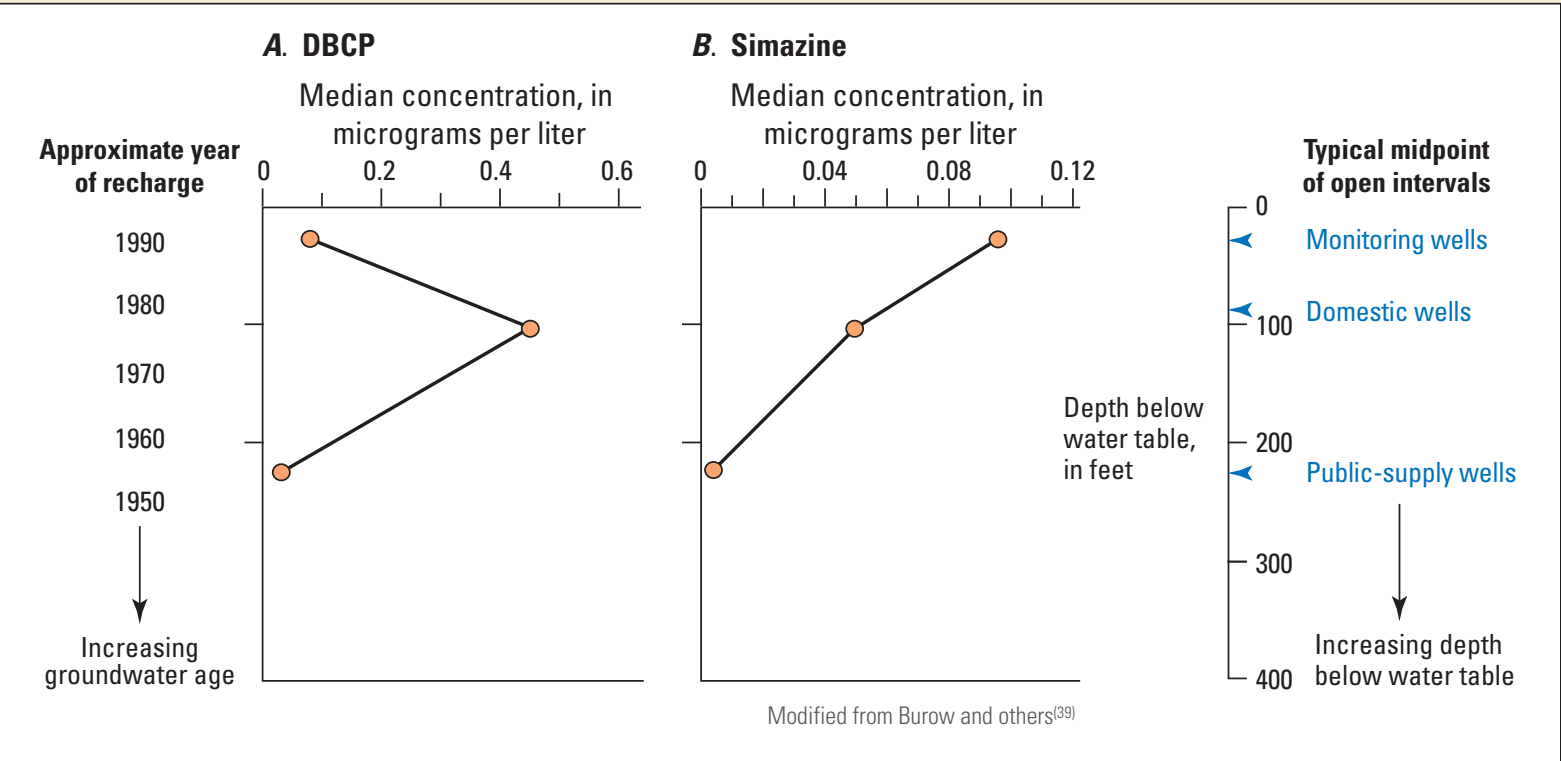

Patterns in concentrations of the pesticides $A$, dibromochloropropane (DBCP) and $B$, simazine with depth in the aquifer beneath agricultural settings in the eastern San Joaquin Valley, California, reflect the history of local chemical use. For DBCP, the decrease in concentrations in groundwater recharged between about 1980 and 1990 reflects a 1977 ban on its use. For simazine, the increase in concentrations in groundwater recharged over the same time period reflects increasing use of this pesticide. 


\section{VOCs and pesticides related to human activities detected in young groundwater from public-supply wells in Salt Lake Valley, Utah}

The presence of young groundwater (recharged since about 1950) and VOCs and pesticides introduced by human activities is related in Salt Lake Valley, Utah. At least one VOC or pesticide compound was detected in 19 of 20 public-supply wells that produced dominantly young groundwater or a mixture of young and old water. Even in discharge areas of the valley where groundwater would be expected to be old, some public-supply wells that pump water from beneath relatively extensive clay layers, which confine and impede vertical groundwater flow and protect groundwater quality, produced a component of young groundwater. Short circuiting between open intervals in a well or reversals in the upward gradient caused by pumping could allow young groundwater at shallow depths to move down past the clay layers. In contrast to detection frequencies in young groundwater, a VOC or a pesticide compound was detected in only 3 of 11 public-supply wells that produced dominantly old water, and all of the concentrations were low. These results demonstrate that human activities in the Salt Lake Valley have caused young, contaminated groundwater to move past protective clay layers to deeper parts of the aquifer used for public supply and that clay layers are not always effective at protecting groundwater quality.
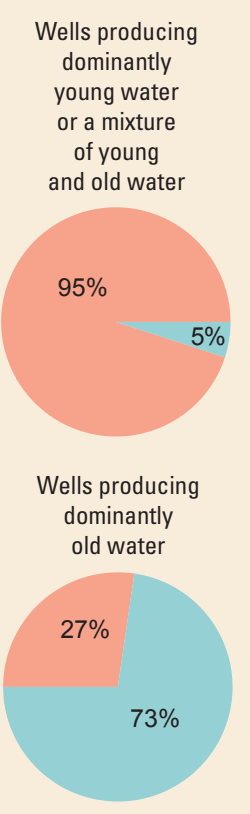

VOC or pesticide compound detected

No VOC or pesticide compound detected
VOC and pesticide compounds in Salt Lake Valley, Utah, groundwater

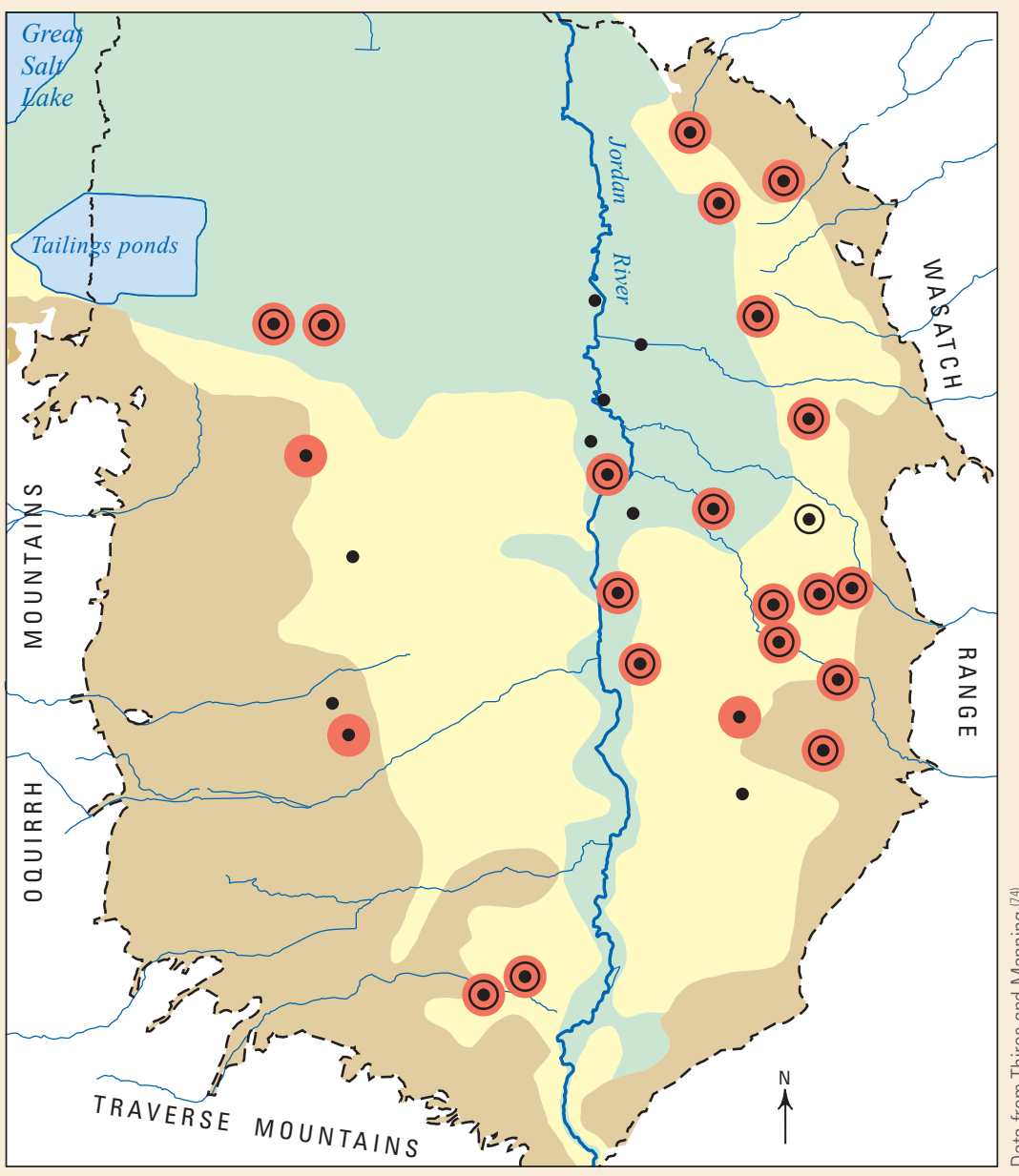

EXPLANATION

Primary recharge area-Few clay layers; unconfined aquifer conditions

Secondary recharge area-Some relatively discontinuous clay layers; confined aquifer conditions Discharge area-Relatively extensive, continuous clay layers; confined aquifer conditions

- - - Boundary of basin-fill sediments

- Public-supply well, old groundwater

(9) Public-supply well, dominantly young groundwater or a mixture of young and old groundwater VOC or pesticide compound detected
Of 31 public-supply wells sampled in Salt Lake Valley, Utah, at least one VOC or pesticide was detected in almost all of the wells that pumped a substantial fraction of "young" groundwater (recharged since about 1950). Unexpectedly, some young, contaminated groundwater occurred in wells in discharge areas with extensive clay layers, indicating that these areas also are vulnerable to groundwater contamination from human activities. 


\section{For more information about NAWQA Principal Aquifer studies}

Groundwater quality for many of the Nation's Principal Aquifers is characterized in U.S. Geological Survey Circular 1360. This report and links to other Principal Aquifer circulars are available at http://water.usgs.gov/nawqa/pasumm/.

More than 2,000 NAWQA Program reports are available online at http://water.usgs.gov/nawqa/bib/.
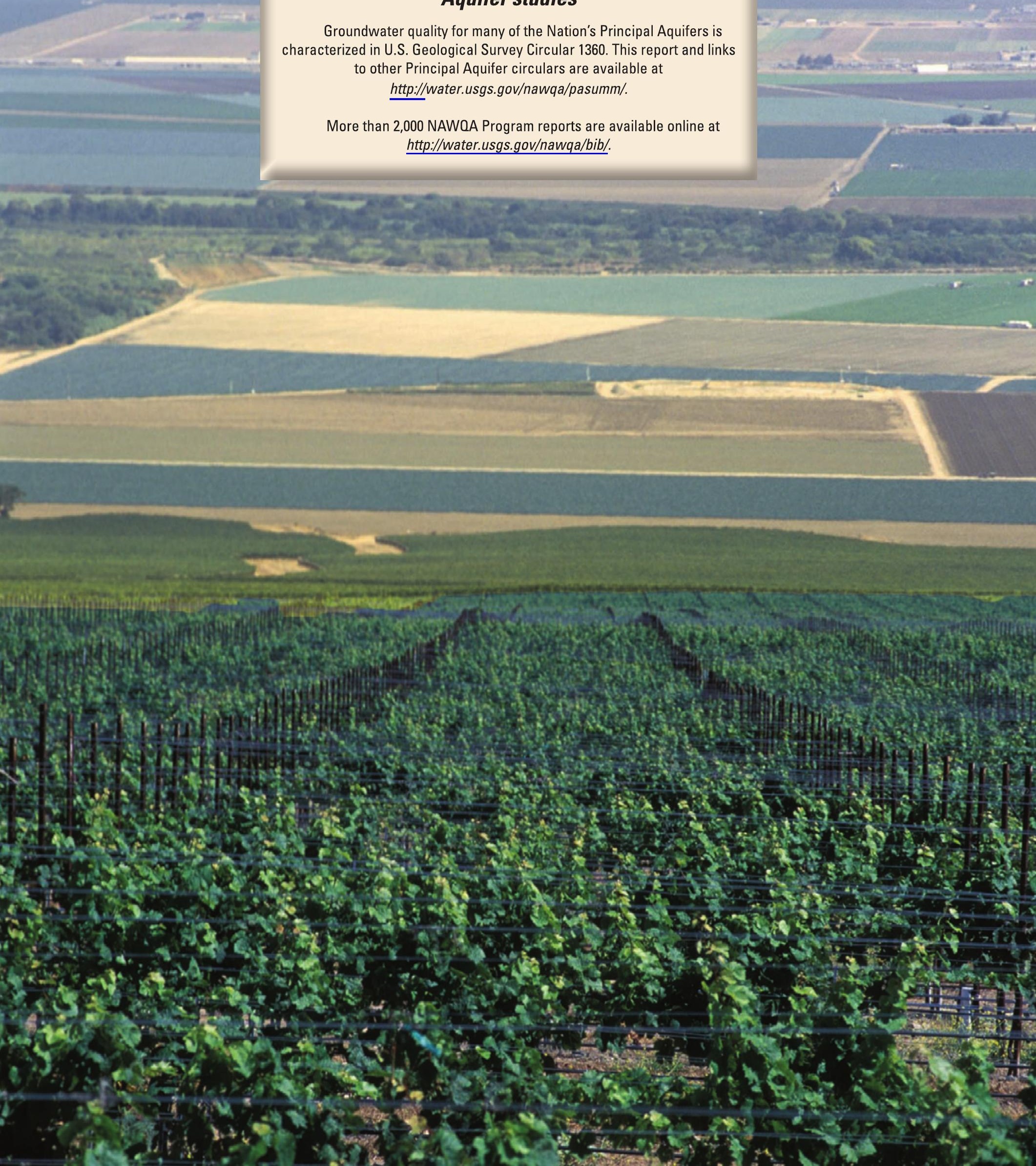


\section{References Cited}

1. Gilliom, R.J., Alley, W.M., and Gurtz, M.E., 1995, Design of the National Water-Quality Assessment Program-Occurrence and distribution of water-quality conditions: U.S. Geological Survey Circular 1112, 33 p., accesed August 14, 2013, at http://pubs.usgs.gov/circ/ circ1112\%.

2. Hopple, J.A., Delzer, G.C., and Kingsbury, J.A., 2009, Anthropogenic organic compounds in source water of selected community water systems that use groundwater, 2002-05: U.S. Geological Survey Scientific Investigations Report 2009-5200, 74 p., accessed August 12, 2013, at http://pubs.usgs.gov/sir/2009/5200/.

3. Eberts, S.M., Thomas, M.A., and Jagucki, M.L., 2013, The quality of our Nation's waters-Factors affecting public-supply-well vulnerability to contaminationUnderstanding observed water quality and anticipating future water quality: U.S. Geological Survey Circular 1385,120 p. (Also available at http://pubs.usgs.gov/ circ/1385/.)

4. McKinney, T.S., and Anning, D.W., 2009, Geospatial data to support analysis of water-quality conditions in basin-fill aquifers in the southwestern United States: U.S. Geological Survey Scientific Investigations Report 2008-5239, 16 p. (Also available at http://pubs.usgs.gov/sir/2008/5239/.)

5. Woodhouse, C.A., Meko, D.M., MacDonald, G.M., Stahle, D.W., and Cook, E.R., 2010, A 1,200-year perspective of 21 st century drought in southwestern North America: Proceedings of the National Academy of Sciences of the United States of America, v. 107, no. 50, p. 21283-21288.

6. Stonestrom, D.A., and Harrill, J.R., 2007, Ground-water recharge in the arid and semiarid southwestern United States - Climatic and geologic framework, in Stonestrom, D.A., Constantz, Jim, Ferré, T.P.A., and Leake, S.A., eds., Ground-water recharge in the arid and semiarid southwestern United States: U.S. Geological Survey Professional Paper, 1703-A, p. 1-27. (Also available at http://pubs.usgs.gov/pp/pp1703/a/.)

7. Oak Ridge National Laboratory, 2005, LandScan ${ }^{\mathrm{TM}}$ global population database: Oak Ridge National Labora-

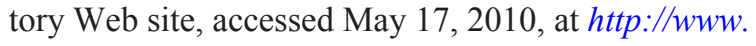
ornl.gov/landscan/.

8. U.S. Census Bureau, 2005, Interim state population projections - Table 1 - Ranking of census 2000 and projected 2030 state population and change: U.S. Census Bureau Web site, accessed April 12, 2012, at http://www. census.gov/population/projections/data/state/.
9. Thiros, S.A., Bexfield, L.M., Anning, D.W., and Huntington, J.M., eds., 2010, Conceptual understanding and groundwater quality of selected basin-fill aquifers in the southwestern United States: U.S. Geological Survey Professional Paper 1781, 288 p. (Also available at http://pubs.usgs.gov/pp/1781/.)

10. Howard, J.B., 1992, Hohokam legacy-Desert canals: Pueblo Grande Museum Profiles no. 12, 5 p., accessed August 28, 2013, at http://waterhistory.org/histories/ hohokam2/hohokam 2.pdf.

11. Great Valley Center, 2009, The state of the great Central Valley of California-Assessing the region via indicators-The economy ( $3 \mathrm{~d}$ ed.): Modesto, Calif., Great Valley Center, 40 p., accessed April 12, 2012, at $h t t p: / / w w w . g r e a t v a l l e y . o r g / w p$-content/ uploads/2012/01/3rd_2009_Economy.pdf.

12. U.S. Department of Agriculture, 2009, Census of agriculture, 2007 census volume 1, chapter 2-County level data, Arizona: U.S. Department of Agriculture Web site,

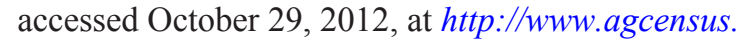
usda.gov/Publications/2007/Full_Report/Volume_1, Chapter_2_County_Level/Arizona/.

13. Maupin, M.A., and Barber, N.L., 2005, Estimated withdrawals from Principal Aquifers in the United States, 2000: U.S. Geological Survey Circular 1279, 46 p. (Also available at $h t t p: / / p u b s . u s g s . g o v / c i r c / 2005 / 1279 /$.)

14. Anning, D.W., and Konieczki, A.D., 2005, Classification of hydrogeologic areas and hydrogeologic flow systems in the Basin and Range Physiographic Province, southwestern United States: U.S. Geological Survey Professional Paper 1702, 37 p. (Also available at http://pubs.usgs.gov/pp/2005/pp1702/.)

15. McMahon, P.B., Cowdery, T.K., Chapelle, F.H., and Jurgens, B.C., 2009, Redox conditions in selected Principal Aquifers of the United States: U.S. Geological Survey Fact Sheet 2009-3041, 6 p. (Also available at $h t t p: / / p u b s . u s g s . g o v / f s / 2009 / 3041 /$.)

16. Zogorski, J.S., Carter, J.M., Ivahnenko, Tamara, Lapham, W.W., Moran, M.J., Rowe, B.L., Squillace, P.J., and Toccalino, P.L., 2006, The quality of our Nation's waters-Volatile organic compounds in the Nation's ground water and drinking-water supply wells: U.S. Geological Survey Circular 1292, 101 p. (Also available at http://pubs.usgs.gov/circ/circ1292/.)

17. Seiler, R.L., and Allander, K.K., 1993, Water-level changes and direction of ground-water flow in the shallow aquifer, Fallon area, Churchill County, Nevada: U.S. Geological Survey Water-Resources Investigations Report 93-4118, 74 p.

18. Welch, A.H., and Lico, M.S., 1998, Factors controlling As and $\mathrm{U}$ in shallow ground water, southern Carson Desert, Nevada: Applied Geochemistry, v. 13, no. 4, p. 521-539. 
19. Bexfield, L.M., Thiros, S.A., Anning, D.W., Huntington, J.M., and McKinney, T.S., 2011, Effects of natural and human factors on groundwater quality of basin-fill aquifers in the southwestern United States - Conceptual models for selected contaminants: U.S. Geological Survey Scientific Investigations Report 2011-5020, 90 p. (Also available at http://pubs.usgs.gov/sir/2011/5020/.)

20. National Research Council, 2001, Arsenic in drinking water-2001 update: Washington, D.C., National Academy Press, $225 \mathrm{p}$.

21. U.S. Environmental Protection Agency, 1999, Proposed radon in drinking water rule: U.S. Environmental Protection Agency Technical Fact Sheet 815-F-99-006, 6 p., accessed February 8, 2012, at http://www.epa.gov/ ogwdw000/radon/fact10.pdf.

22. U.S. Environmental Protection Agency, 2009, Proposed radon in drinking water rule: U.S. Environmental Protection Agency Web site, accessed February 24, 2010, at http://www.epa.gov/safewater/radon/proposal.html.

23. U.S. Environmental Protection Agency, 2012, Secondary drinking water regulations-Guidance for nuisance chemicals: U.S. Environmental Protection Agency 816-F-10-079, accessed April 24, 2013 http://water. epa.gov/drink/contaminants/secondarystandards.cfm.

24. Ayers, R.S., and Wescot, D.W., 1994, Water quality for agriculture: Food and Agriculture Organization Irrigation and Drainage Paper 29, 174 p., accessed June 15, 2012, at http://www.fao.org/DOCREP/003/T0234E/ T0234E00.HTM.

25. U.S. Environmental Protection Agency, 2001, Drinking water standard for arsenic: U.S. Environmental Protection Agency Fact Sheet EPA 815-F-00-015, accessed December 22, 2010, at http://water.epa.gov/lawsregs/ rulesregs/sdwa/arsenic/regulations_factsheet.cfm.

26. Welch, A.H., Westjohn, D.B., Helsel, D.R., and Wanty, R.B., 2000, Arsenic in ground water of the United States-Occurrence and geochemistry: Ground Water, v. 38 , no. 4 , p. $589-604$.

27. Robertson, F.N., 1989, Arsenic in groundwater under oxidizing conditions, southwest United States: Environmental Geochemistry and Health, v. 11, nos. 3-4, p. 171-185.

28. Anning, D.W., Paul, A.P., McKinney, T.S., Huntington, J.M., Bexfield, L.M., and Thiros, S.A., 2012, Predicted nitrate and arsenic concentrations in basin-fill aquifers of the southwestern United States: U.S. Geological Survey Scientific Investigations Report 2012-5065, 78 p., 17 app., (Also available at http://pubs.usgs.gov/sir/2012/5065/.)
29. U.S. Environmental Protection Agency, 2010, Basic information about the radionuclides rule: U.S. Environmental Protection Agency Web site, accessed March 22, 2011, at http://water.epa.gov/lawsregs/rulesregs/sdwa/ radionuclides/basicinformation.cfm.

30. Fujii, Roger, and Swain, W.C., 1995, Areal distribution of selected trace elements, salinity, and major ions in shallow ground water, Tulare Basin, southern San Joaquin Valley, California: U.S. Geological Survey WaterResources Investigations Report 95-4048, 67 p., 1 pl.

31. Ayotte, J.D., Gronberg, J.M., and Apodaca, L.E., 2011, Trace elements and radon in groundwater across the United States, 1992-2003: U.S. Geological Survey Scienti ic Investigations Report 2011-5059, 115 p. (Also available at $h t t p: / / p u b s . u s g s . g o v / s i r / 2011 / 5059 /$.

32. Jurgens, B.C., Fram, M.S., Belitz, Kenneth, Burow, K.R., and Landon, M.K., 2010, Effects of groundwater development on uranium, Central Valley, California, USA: Ground Water, v. 48, no. 6, p. 913-928.

33. Wanty, R.B., and Nordstrom, D.K., 1993, Natural radionuclides, in Alley, W.M., ed., Regional ground-water quality: New York, Van Nostrand Reinhold, chap. 17, p. $423-441$.

34. Thomas, J.M., Welch, A.H., Lico, M.S., Hughes, J.L., and Whitney, Rita, 1993, Radionuclides in ground water of the Carson River Basin, western Nevada and eastern California, U.S.A.: Applied Geochemistry, v. 8, p. $447-471$.

35. DeSimone, L.A., 2009, Quality of water from domestic wells in Principal Aquifers of the United States, 1991-2004: U.S. Geological Survey Scientific Investigations Report 2008-5227, 127 p. (Also available at http://pubs.usgs.gov/sir/2008/5227/.)

36. U.S. Environmental Protection Agency, 2012, National primary drinking water regulations-Drinking water contaminants: U.S. Environmental Protection Agency Web site, accessed May 25, 2012 http://water.epa.gov/ drink/contaminants/index.cfm.

37. Paul, A.P., Seiler, R.L., Rowe, T.G., and Rosen, M.R., 2007, Effects of agriculture and urbanization on quality of shallow ground water in the arid to semiarid western United States, 1993-2004: U.S. Geological Survey Scientific Investigations Report 2007-5179, 56 p.

38. Edmonds, R.J., and Gellenbeck, D.J., 2002, Groundwater quality in the West Salt River Valley, Arizona, 1996-98 - Relations to hydrogeology, water use, and land use: U.S. Geological Survey Water Resources Investigations Report 01-4126, 58 p., accessed July 5, 2012, at http://az.water.usgs.gov/pubs/WRIR014126intro.html. 
39. Burow, K.R., Shelton, J.L., and Dubrovsky, N.M., 2008, Regional nitrate and pesticide trends in ground water in the eastern San Joaquin Valley, California: Journal of Environmental Quality, v. 37, September-October [supplement], p. S249-S263, doi:10.2134/jeq2007.0061.

40. Rosen, M.R., 2003, Trends in nitrate and dissolvedsolids concentrations in ground water, Carson Valley, Douglas County, Nevada, 1985-2001: U.S. Geological Survey Water Resources Investigations Report 03-4152, 6 p. (Also available at http://pubs.usgs.gov/wri/ wri034152/.)

41. National Atmospheric Deposition Program, 2010, National trends network data: National Atmospheric Deposition Program Web site, accessed July 5, 2012, at http://nadp.sws.uiuc.edu/data/.

42. Dubrovsky, N.M., Burow, K.R., Clark, G.M., Gronberg, J.M., Hamilton, P.A., Hitt, K.J., Mueller, D.K., Munn, M.D., Nolan, B.T., Puckett, L.J., Rupert, M.G., Short, T.M., Spahr, N.E., Sprague, L.A., and Wilber, W.G., 2010, The quality of our Nation's waters-Nutrients in the Nation's streams and groundwater, 1992-2004: U.S. Geological Survey Circular 1350, 174 p., accessed March 14, 2012, at http://pubs.usgs.gov/circ/1350/.

43. Walvoord, M.A., Phillips, F.M., Stonestrom, D.A., Evans, R.D., Hartsough, P.C., Newman, B.D., and Striegl, R.G., 2003, A reservoir of nitrate beneath desert soils: Science, v. 302, no. 5647, p. 1021-1024.

44. Anning, D.W., Bauch, N.J., Gerner, S.J., Flynn, M.E., Hamlin, S.N., Moore, S.J., Schaefer, D.H., Anderholm, S.K., and Spangler, L.E., 2007, Dissolved solids in basin-fill aquifers and streams in the southwestern United States: U.S. Geological Survey Scientific Investigations Report 2006-5315, 168 p. (Also available at http://pubs.usgs.gov/sir/2006/5315/.)

45. Southern California Salinity Coalition, 2009, Salinity and water softeners: Fountain Valley, Calif., Southern California Salinity Coalition Salinity Fact Sheet, 2 p., accessed February 25, 2011, at http://www.socalsalinity.org/.

46. Gilliom, R.J., Barbash, J.E., Crawford, C.G., Hamilton, P.A., Martin, J.D., Nakagaki, Naomi, Nowell, L.H., Scott, J.C., Stackelberg, P.E., Thelin, G.P., and Wolock, D.M., 2006, The quality of our Nation's waters-Pesticides in the Nation's streams and ground water, 19922001: U.S. Geological Survey Circular 1291, 172 p. (Also available at $h t t p: / / p u b s . u s g s . g o v / c i r c / 2005 / 1291 /$.

47. U.S. Geological Survey, 2010, Pesticide use maps for 1992, 1997, and 2002: U.S. Geological Survey Web site, accessed June 10, 2013, at http://water.usgs.gov/nawqa/ pnsp/usage/maps/.
48. U.S. Environmental Protection Agency, 2009, Water on tap-What you need to know: U.S. Environmental Protection Agency Office of Water EPA 816-K-09-002, 34 p., accessed June 14, 2011, at http://water.epa.gov/ drink/guide/upload/book_waterontap_full.pdf.

49. Welch, A.H., Bright, D.J., and Knochenmus, L.A., eds., 2007, Water resources of the Basin and Range carbonate-rock aquifer system, White Pine County, Nevada, and adjacent areas in Nevada and Utah: U.S. Geological Survey Scienti ic Investigations Report

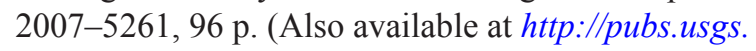
gov/sir/2007/5261/.)

50. Heilweil, V.M., and Brooks, L.E., eds., 2011, Conceptual model of the Great Basin carbonate and alluvial aquifer system: U.S. Geological Survey Scienti ic Investigations Report, 191 p. (Also available at http://pubs.usgs.gov/ sir/2010/5193/.)

51. Schaefer, D.H., Thiros, S.A., and Rosen, M.R., 2011, Ground-water quality in the carbonate-rock aquifer of the Great Basin, Nevada and Utah, 2003: U.S. Geological Survey Scienti ic Investigations Report 2005-5232,

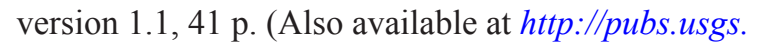
gov/sir/2005/5232/.)

52. Maupin, M.A., and Arnold, T.L., 2010, Estimates for self-supplied domestic withdrawals and population served for selected Principal Aquifers, calendar year 2005: U.S. Geological Survey Open-File Report 2010-1223, 10 p. (Also available at http://pubs.usgs. gov/of/2010/1223/.)

53. Carpenter, Everett, 1915, Ground water in southeastern Nevada: U.S. Geological Survey Water-Supply Paper 365, 86 p., accessed August 16, 2013, at http://pubs. er.usgs.gov/publication/wsp 365.

54. Harrill, J.R., 1976, Pumping and ground-water storage depletion in Las Vegas Valley, Nevada, 1955-74: Nevada Department of Conservation and Natural Resources Bulletin 44, $70 \mathrm{p}$.

55. Wildermuth Environmental, Inc., 2007, 2007 CBWM groundwater model documentation and evaluation of the Peace II project description: Wildermuth Environmental, Inc., Chino Basin Watermaster, accessed June 24, 2013, at $h$ ttp://rmp.wildermuthenvironmental.com/supportingdocs.html.

56. Cone, Tracy, 1997, The vanishing valley: San Jose Mercury News West Magazine, June 29, p. 9-15.

57. Landon, M.K., Jurgens, B.C., Katz, B.G., Eberts, S.M., Burow, K.R., and Crandall, C.A., 2009, Depth-dependent sampling to identify short-circuit pathways to public-supply wells in multiple aquifer settings in the United States: Hydrogeology Journal, v. 18, no. 3, p. 577-593, accessed July 9, 2014, at http://oh.water.usgs.gov/tanc/ pubs/landon_DOI10.1007s10040-009-0531-2.pdf. 
58. Jurgens, B.C., Burow, K.R., Dalgish, B.A., and Shelton, J.L., 2008, Hydrogeology, water chemistry, and factors affecting the transport of contaminants in the zone of contribution of a public-supply well in Modesto, eastern San Joaquin Valley, California: U.S. Geological Survey Scientific Investigations Report 2008-5156, 78 p. (Also available at $h$ ttp://pubs.usgs.gov/sir/2008/5156/.)

59. Toccalino, P.L., Norman, J.E., Phillips, R.H., Kauffman, L.J., Stackelberg, P.E., Nowell, L.H., Krietzman, S.J., and Post, G.B., 2004, Application of health-based screening levels to ground-water quality data in a statescale pilot effort: U.S. Geological Survey Scientific Investigations Report 2004-5174, 64 p. (Also available at $h t t p: / / p u b s . u s g s . g o v /$ sir/2004/5174/.)

60. Toccalino, P.L., 2007, Development and application of health-based screening levels for use in water-quality assessments: U.S. Geological Survey Scientific Investigations Report 2007-5106, 12 p. (Also available at http://pubs.usgs.gov/sir/2007/5106/.)

61. Toccalino, P.L., Norman, J.E., Booth, N.L., Thompson, J.L., and Zogorski, J.S., 2012, Health-based screening levels-Benchmarks for evaluating water-quality data: U.S. Geological Survey Web site, accessed April 24, 2013 http://water.usgs.gov/nawqa/HBSL/.

62. U.S. Environmental Protection Agency, 1994, Evaluating and identifying contaminants of concern for human health: U.S. Environmental Protection Agency Region 8 Superfund Technical Guidance RA-03, 10 p., accessed September 23, 2013, at http://www2.epa.gov/sites/ production/files/documents/r8_ra03-cocs.pdf.

63. New Jersey Department of Environmental Protection, 2003, Susceptibility of source water to community water-supply wells in New Jersey to contamination by volatile organic compounds: Trenton, N.J., New Jersey Department of Environmental Protection, 21 p., accessed September 23, 2013, at http://www.state.nj.us/ dep/swap/reports/gw_voc.pdf.

64. Rao, Balaji, Anderson, T.A., Orris, G.J., Rainwater, K.A., Rajagopalan, Srinath, Sandvig, R.M., Scanlon, B.R., Stonestrom, D.A., Walvoord, M.A., and Jackson, W.A., 2007, Widespread natural perchlorate in unsaturated zones of the southwest United States: Environmental Science and Technology, v. 41, no. 13, p. 4522-4528.

65. U.S. Environmental Protection Agency, 2009, Emerging contaminant-Perchlorate: U.S. Environmental Protection Agency Office of Solid Waste and Emergency Response Fact Sheet EPA 505-F-09-005, 4 p., accessed January 28, 2010, at http://www.clu-in.org/download/ contaminantfocus/epa505f09005.pdf.
66. Fram, M.S., and Belitz, Kenneth, 2011, Probability of detecting perchlorate under natural conditions in deep groundwater in California and the southwestern United States: Environmental Science and Technology, v. 45, issue 4, p. 1271-1277, accessed May 22, 2012, at http://pubs.acs.org/doi/full/10.1021/es103103p.

67. California State Water Resources Control Board, 2010, Perchlorate: California State Water Resources Control Board Groundwater Information Sheet, 11 p., accessed April 12, 2011, at http://www.waterboards.ca.gov/ water_issues/programs/gama/docs/coc_perchlorate.pdf.

68. U.S. Environmental Protection Agency, 2011, Fiscal year 2010 drinking water and ground water statistics: U.S. Environmental Protection Agency Office of Ground Water and Drinking Water EPA 817-K11-001, accessed May 29, 2012, at http://water.epa. gov/scitech/datait/databases/drink/sdwisfed/upload/ new_Fiscal-Year-2010-Drinking-Water-andGround-Water-Statistics.pdf.

69. White, E.L., 2012, Fallon, NV_-Pooling resources to construct arsenic treatment facility: U.S. Environmental Protection Agency Arsenic in Drinking Water Compliance Success Stories, 5 p., accessed February 29, 2012, at $h t t p: / / w w w . e p a . g o v / o g w d w / a r s e n i c / c a s e s t u d i e s / p d f s /$. casestudy fallon.pdf.

70. Walker, Mark, and Montecinos, Crystel, 2001, Arsenic in drinking water-Issues associated with revising the standard: Reno, University of Nevada Cooperative Extension Fact Sheet 01-08, 4 p., accessed July 15, 2014, at http://www.unce.unr.edu/publications/iles/ ag/2001/fs0108.pdf.

71. Flanagan, S.M., Ayotte, J.D., and Robinson, G.R., Jr., 2012, Quality of water from crystalline rock aquifers in New England, New Jersey, and New York, 1995-2007: U.S. Geological Survey Scienti ic Investigations Report 2011-5220, 104 p. (Also available at http://pubs.usgs. gov/sir/2011/5220/.)

72. Harter, Thomas, Lund, J.R., Darby, Jeannie, Fogg, G.E., Howitt, Richard, Jessoe, K.K., Pettygrove, G.S., Quinn, J.F., Viers, J.H., and others, 2012, Addressing nitrate in California's drinking water, with a focus on Tulare Lake Basin and Salinas Valley groundwater: Davis, Calif., University of California, Davis, 78 p., accessed July 3, 2012, at http://groundwaternitrate.ucdavis.edu/.

73. Alley, W.M., 2003, Desalination of ground water-Earth science perspectives: U.S. Geological Survey Fact Sheet 075-03, 4 p. (Also available at http://pubs.usgs.gov/fs/ fs075-03/pdf/AlleyFS.pdf.) 
74. Thiros, S.A., and Manning, A.H., 2004, Quality and sources of ground water used for public supply in Salt Lake Valley, Salt Lake County, Utah, 2001: U.S. Geological Survey Water-Resources Investigations Report 03-4325, 95 p. (Also available at http://pubs.water.usgs. gov/wri034325/.)

75. Thiros, S.A., and Spangler, L.E., 2010, Decadal-scale changes in dissolved-solids concentrations in groundwater used for public supply, Salt Lake Valley, Utah: U.S. Geological Survey Fact Sheet 2010-3073, 6 p. (Also available at http://pubs.usgs.gov/fs/2010/3073/.)

76. Belitz, Kenneth, Hamlin, S.N., Burton, C.A., Kent, Robert, Fay, R.G., and Johnson, Tyler, 2004, Water quality in the Santa Ana Basin, California, 1999-2001: U.S. Geological Survey Circular 1238, 38 p. (Also available at http://pubs.usgs.gov/circ/2004/1238/.)

77. Groundwater Replenishment System, 2013, Groundwater replenishment system: Fountain Valley, Calif., Groundwater Replenishment System Fact Sheet, 24 p., accessed May 2, 2013, at http://www.gwrsystem.com/ images/stories/AboutGWRS/GWRS\%20Technical\%20 Brochure.pdf.

78. Plummer, L.N., Bexfield, L.M., Anderholm, S.K., Sanford, W.E., and Busenberg, Eurybiades, 2004, Geochemical characterization of ground-water flow in the Santa Fe Group aquifer system, Middle Rio Grande Basin, New Mexico: U.S. Geological Survey Water-Resources Investigations Report 03-4131, 395 p. (Also available at http://pubs.usgs.gov/wri/wri034131/.)
79. U.S. Geological Survey, 2004, Estimated use of water in the United States - County-level data for 2000: U.S. Geological Survey Web site, accessed June 10, 2013, at http://water.usgs.gov/watuse/data/2000/index.html.

80. Wildermuth Environmental, Inc., 2008, Recomputation of ambient water quality in the Santa Ana Watershed for the period 1987 to 2006: Wildermuth Environmental, Inc. Final Technical Memorandum [prepared for the Basin Monitoring Program Task Force; variously paged].

81. Faunt, C.C., Hanson, R.T., and Belitz, Kenneth, 2009, Introduction, overview of hydrology, and textural model of California's Central Valley, in Faunt, C.C., ed., Groundwater availability of the Central Valley Aquifer, California: U.S. Geological Survey Professional Paper 1766, p. 1-57. (Also available at http://pubs.usgs.gov/ pp/1766/.)

82. National Ground Water Association, 2010, Brackish groundwater: Westerville, Ohio, National Ground Water Association Information Brief, 4 p., accessed May 15, 2012, at http://www.ngwa.org/Media-Center/briefs/ Documents/Brackish_water_info_brief_2010.pdf.

83. Homer, C.H., Fry, J.A., and Barnes, C.A., 2012, The National Land Cover Database: U.S. Geological Survey Fact Sheet 2012-3020, 4 p. (Also available at http://pubs.usgs.gov/fs/2012/3020/fs2012-3020.pdf.)

84. Desimone, L.A., McMahon, P.B., and Rosen, M.R., 2014, The quality of our Nation's waters - Water quality in Principal Aquifers of the United States, 1991-2010: U.S. Geological Survey Circular 1360, 151 p. (Also available at http://dx.doi.org/10.3133/cir1360.) 


\section{Glossary}

A

adsorption Process in which ions or molecules dissolved in groundwater become attached to the surfaces of solid materials, such as sediment or rock particles in aquifers, either temporarily or permanently.

alluvial fan A low, outspread, relatively flat to gently sloping mass of loose rock material, shaped like an open fan or a segment of a cone, deposited by a stream (especially in a semiarid region) at the place where the rock mass issues from a narrow mountain valley on a plain or broad valley.

anoxic Water with no dissolved oxygen or a very low concentration (less than 0.5 milligram per liter) of dissolved oxygen.

aquifer A geologic formation, group of formations, or part of a formation that contains a sufficient amount of saturated permeable material (for example, soil, sand, gravel and (or) rock) to yield substantial quantities of water to wells and springs.

artesian Referring to confined groundwater. If the potentiometric surface in a confined aquifer is higher than the land surface, water discharges spontaneously from a well tapping the aquifer; this is called a "flowing artesian well."

artificial recharge Replenishment of an aquifer through human effort, for example, spreading water, recharge wells, or ditches; recharge through human activities that occurs at a rate greater than that of naturally occurring activities; the water artificially recharging an aquifer.

\section{B}

background concentration A concentration of a substance in a particular environment that corresponds to minimal influence by human (anthropogenic) sources or activities. base flow Groundwater seepage into a stream or river. The continual contribution of groundwater to streams and rivers is an important source of streamflow between rain events.

biotic community A group of organisms that exist together because the organisms possess an integrated system (food chain or food web) of energy transfer operating through several different feeding or trophic levels.

\section{C}

closed basin An enclosed area having no drainage outlet, from which water escapes only by evaporation, as in an arid region.

common assessment level A single concentration threshold used to establish an equal basis for comparing detection frequencies among multiple chemicals. Use of a common assessment level avoids biases in detection frequencies caused by one compound having a lower detection level than another. Also sometimes referred to as a "common detection level."

complexation A chemical process that combines simple ions into a larger ion or by which an ion adheres to a charged surface.

confined aquifer (artesian aquifer) An aquifer in which the groundwater is bounded between layers of relatively impermeable material, such as clay or dense rock. When tapped by a well, water in a confined aquifer is forced up, sometimes above the land surface, by pressure within the aquifer.

confining layer Geologic material with little or no permeability or hydraulic conductivity. Water does not pass through this layer or the rate of movement is extremely slow.

consolidated rock Tightly bound geologic formation composed of sandstone, limestone, granite, or other rock.

constituent A chemical or biological substance in water, sediment, or biota that can be measured by an analytical (laboratory) method. 
contaminant For the purposes of this report, any manmade compound at any concentration, or any constituent with a geologic source measured at a concentration exceeding the designated human-health benchmark.

\section{D}

degradate A compound formed by the transformation of a parent compound, typically an organic contaminant or another degradate, by chemical, photochemical, or biological reactions.

denitrification The bacterial reduction of dissolved nitrate to nitrogen gas. Denitrification is the primary process by which nitrate can be eliminated naturally in groundwater.

desorption The release of a sorbed material from the solid to which it was sorbed. Opposite process of adsorption.

discharge The rate of flow of surface water or groundwater past a given point at a given moment, expressed as volume per unit of time. Also, the outflow from an aquifer, spring, or well or up through a streambed.

dissolution The process of dissolving a solid (mineral) into a homogeneous solution (water). Dissolution reactions result in the addition of ions to water as minerals react with water. Common dissolution reactions include dissolution of carbonate rock (limestone or dolomite) and incongruent dissolution of silicate minerals (feldspar) by carbonic acid $\left(\mathrm{H}_{2} \mathrm{CO}_{3}\right)$.

domestic well A privately owned well that typically serves one home and supplies water for human consumption and other homeowner uses.

\section{E}

evaporative concentration Process in which high rates of evaporation lead to enrichment of a constituent by removing water and leaving the constituent in the remaining water.

evapotranspiration Loss of water from soil by evaporation and plant transpiration combined.

\section{$\mathbf{F}$}

flow path The route or pathway of water flowing through the hydrologic system. Typically refers to subsurface (groundwater) flow.
G

groundwater recharge The infiltration of water to the saturated zone. Also refers to water that reaches the water table by infiltration of precipitation or irrigation water through the unsaturated zone or by seepage of water from surface-water bodies, such as streams and lakes.

groundwater residence time The average amount of time it takes for groundwater to move from the point where it enters the aquifer to a specific point of discharge, such as a well or stream.

\section{H}

Health-Based Screening Level (HBSL) An estimate of concentration (for a noncarcinogen) or concentration range (for a carcinogen) in water that (1) may be of potential human-health concern, (2) can be used as a threshold value against which measured concentrations of contaminants in ambient groundwater samples can be compared, and (3) is consistent with U.S. Environmental Protection Agency Office of Water methodologies.

human-health benchmark A threshold concentration above which the concentration of a contaminant in drinking water could have adverse effects on human health. Treatment or other measures can be used before the water is consumed to lower the concentration of the contaminant below the benchmark.

hydraulic gradient In an aquifer, the rate of change of total head (water-level altitude in a well) per unit of distance of flow at a given point and in a given direction. Water will flow from higher hydraulic head to lower hydraulic head.

\section{I}

igneous rock Rock that solidified from molten (melted) or partly molten material. Granite is an example of an igneous rock.

intrinsic susceptibility A measure of the ease with which a contaminant in water enters and moves through an aquifer; a characteristic of the aquifer and overlying material and hydrologic conditions independent of the chemical characteristics of the contaminant and its sources. 


\section{$\mathbf{L}$}

land-use study A study by the U.S. Geological Survey National Water-Quality Assessment (NAWQA) Program to assess the effects of a specific land-use type (generally agricultural or urban) on groundwater quality, in most cases by sampling groundwater from monitoring wells that tap water from or near the water table.

legume A member of the large plant family Leguminosae, many of which harbor nitrogen-fixing bacteria on their roots, and many of which contain edible parts. Beans, alfalfa, and mesquite are examples of legumes.

\section{M}

major-aquifer study A study by the U.S. Geological Survey National Water-Quality Assessment (NAWQA) Program that involves sampling of water at 20 to 30 wells (primarily domestic wells) that withdraw water from major aquifers. The major-aquifer studies represent a mix of land uses and target water that is used for drinking-water supply.

\section{Maximum Contaminant Level (MCL)}

Maximum permissible level of a contaminant in water that is delivered to any user of a public water system. MCLs are enforceable standards established by the U.S. Environmental Protection Agency.

metamorphic rock Rock derived from mineralogical, chemical, or structural changes to preexisting rocks in response to marked changes in temperature, pressure, shearing stress, and chemical environment, generally at depth in the Earth's crust. Gneiss and schist are examples of metamorphic rocks.

monitoring well A well used to measure water quality or groundwater levels continuously or periodically. Not typically used as a source of drinking water. Sometimes referred to as an "observation well."

\section{0}

open basin A basin where, under natural conditions, water is drained by a throughflowing stream (the basin is topographically open) or by subsurface outflow, either through basin fill or consolidated rock.

oxic Water with a concentration of dissolved oxygen greater than or equal to 0.5 milligram per liter.

\section{$\mathbf{P}$}

permeability A measure of the relative ease with which a porous or fractured medium can transmit groundwater. Rock formations that transmit fluids readily are described as permeable.

pH A measure of the acidity ( $\mathrm{pH}$ less than 7) or alkalinity ( $\mathrm{pH}$ greater than 7) of a solution; a pH of 7 is neutral. Formally defined as the logarithm of the reciprocal of the hydrogen ion concentration (activity) of a solution.

point source A stationary location or fixed facility from which contaminants are discharged, for example, a pipe, ditch, ship, ore pit, or factory smokestack.

potential evapotranspiration The theoretical maximum loss of water that would occur from a given area by evapotranspiration if unlimited water were available to the root system of plants.

predevelopment The time prior to substantial groundwater development by humans or effects of agricultural, urban, suburban, or other human-related land uses.

Principal Aquifer A regionally extensive aquifer or aquifer system that has the potential to be used as a source of potable water. A Principal Aquifer can be composed of one or more major aquifers.

public-supply well A privately or publicly owned well that provides water for public use to (1) a community water system, (2) a transient noncommunity water system, such as a campground, or (3) a nontransient, noncommunity system, such as a school.

\section{$\mathbf{R}$}

recently recharged groundwater Groundwater that was recharged after 1952, as indicated by tritium concentrations greater than 0.5 tritium unit

reduction/oxidation (redox) Chemical reactions that involve the transfer of electrons from one chemical species to another, resulting in a change in the valence state of the species. Redox processes in groundwater often are microbially facilitated.

\section{S}

saturated The condition in which all the pores (voids, interstices) within a material are filled with a liquid, typically water. 
Secondary Maximum Contaminant Level (SMCL) Guidelines set by the U.S. Environmental Protection Agency for concentrations of "nuisance" constituents in drinking water that may cause unwanted effects, such as unpleasant taste, color, or odor; discoloration of skin or teeth; or corrosion or staining of plumbing fixtures. Public drinking-water systems are recommended but not required to comply with these guidelines.

sedimentary rocks Rocks composed of particles derived from the erosion or weathering of preexisting rocks or from chemical precipitation from water. Sandstone and limestone are examples of sedimentary rocks.

susceptibility See intrinsic susceptibility.

\section{U}

unconfined aquifer An aquifer that has a water table; an aquifer containing unconfined groundwater.

unconsolidated deposit Deposit of loosely bound sediment that typically fills topographically low areas.

unsaturated zone A subsurface zone containing both water and air. The unsaturated zone is limited above by the land surface and below by the water table.

\section{V}

volatile organic compound (VOC) An organic chemical that has a high vapor pressure relative to its water solubility. VOCs include components of gasoline, fuel oils, lubricants, organic solvents, fumigants, some inert ingredients in pesticides, and some byproducts of chlorine disinfection.

vulnerability The tendency or likelihood for contaminants to reach a specified position in the groundwater system after introduction at some location above the uppermost aquifer. The vulnerability of a groundwater resource to contamination depends both on the intrinsic susceptibility of the resource and on the locations and types of human and geologic sources of contaminants, locations of wells, and the characteristics of the contaminant(s).

W

water table The upper surface of the saturated zone below which all voids (spaces) are filled with water. 


\section{Acknowledgments}

\section{Special thanks to the following individuals and organizations for their contributions:}

NAWQA personnel in the Southwest Principal Aquifers study area for their contributions of data and research results.

NAWQA's many partners in the governmental and non-governmental sectors who have helped guide scientific efforts and ensure that NAWQA information meets the needs of local, State, Tribal, regional, and national stakeholders.

\section{USGS reviewers:}

- Devin Galloway

- Lisa Stillings

- Karen Burow

- Wayne Lapham

- Barbara Mahler

- Leslie DeSimone

- Dennis Wentz

- William Wilbur

\section{External reviewers:}

- Bart Faris, New Mexico Environment Department

- Jan Stepek, California State Water Resources Control Board, Division of Water Quality

- Doug Towne, Arizona Department of Environmental Quality 


\section{Appendix 1. Study Components of the Southwest Principal Aquifers Water- Quality Assessment}

\section{How does land use affect groundwater quality? How does water quality change as it moves through an aquifer? What is the quality of the drinking-water resource?}

NAWQA groundwater assessments include different types of studies, specifically designed to answer questions such as these.

- Land-use studies were conducted to sample water from water-table monitoring wells installed in urban and agricultural areas to assess the effects of these land uses on the quality of the underlying groundwater. Although not usually used for drinking, this water supplies recharge to the deeper aquifer system.

- Flow-path studies were conducted to investigate how water quality changes as it moves along a groundwater flow path. Samples were collected from wells installed along a groundwater flow path (http://pubs.usgs.gov/circ/circ1112/flowpath.htm/).

- Major-aquifer studies provide a broad overview of the quality of the deeper aquifer system used for drinking-water supply. Most of the wells sampled were domestic wells that were distributed across a large area in a mixture of land uses.

- Vulnerability or contaminant-transport studies were designed to assess the vulnerability of water delivered by public-supply wells to contamination from natural and manmade contaminants. Samples were collected from multiple depths in public-supply wells to determine where and how contaminants from different sources enter the wells and how natural processes and human activities affect water quality (http://oh.water.usgs.gov/tanc/NAWQATANC.htm).

- Source-water quality assessment studies were conducted to sample water from public-supply wells to understand the occurrence of unregulated manmade chemicals in the groundwater resources that serve large numbers of people (http://water.usgs.gov/nawqa/swqa/).

Results of these studies were reinforced by locating some of the studies within the boundaries of larger studies. For example, the recharge areas for flow-path studies were located within the boundaries of the land-use studies to provide information on the quality of the recharge. In turn, the boundaries of the land-use studies were located within the boundaries of the major-aquifer studies to provide information on how the quality of the recharge affects that of the deeper groundwater.

For each study, water was sampled from a network of a few to as many as 30 wells. Data from these studies were available for the Principal Aquifer assessments.

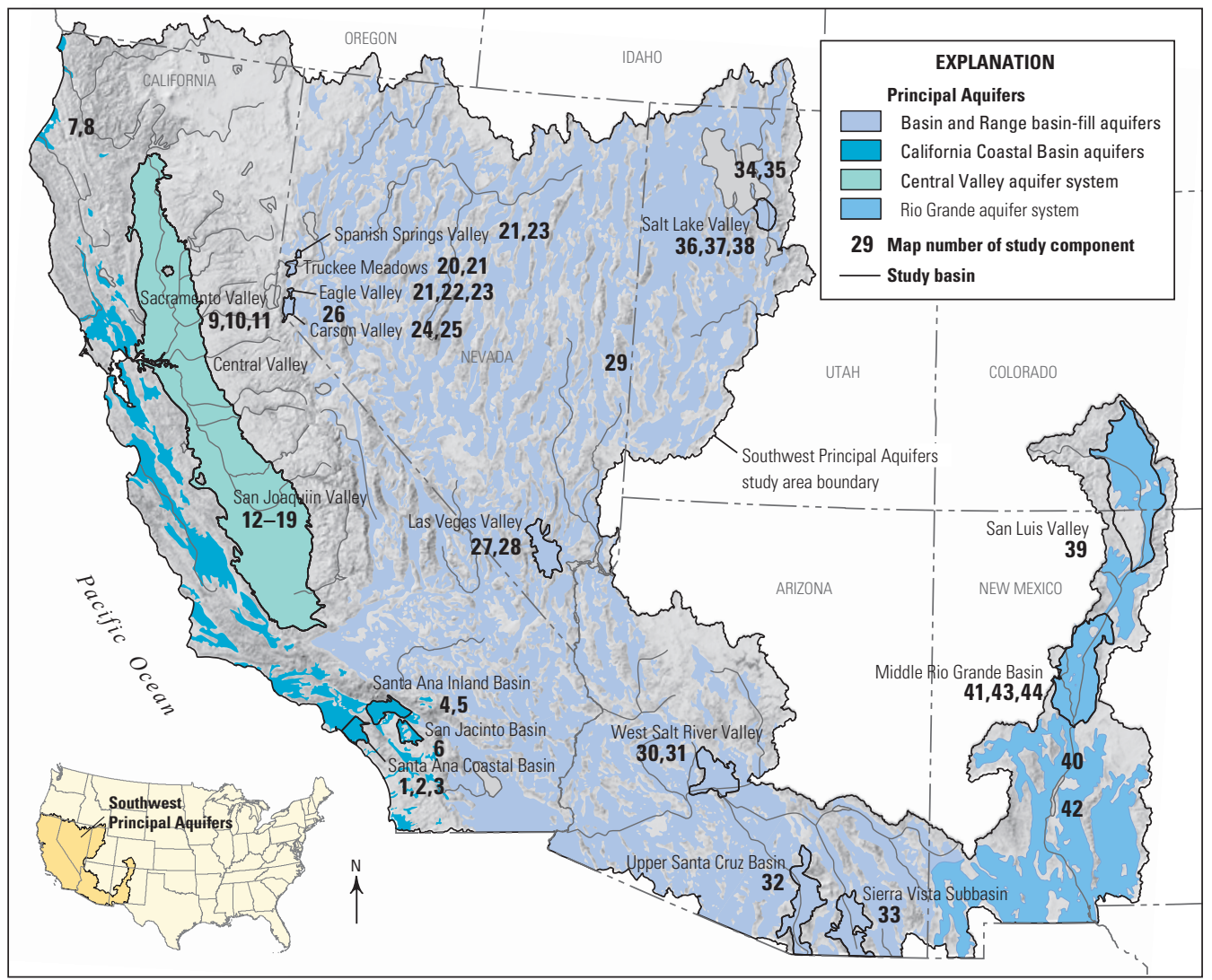




\section{Table A1-1. Study components of the Southwest Principal Aquifers water-quality assessment.}

[F, field parameters including water temperature, specific conductance, $\mathrm{pH}$, alkalinity, turbidity, and dissolved oxygen; M, major ions; $\mathrm{N}$, nutrients; $\mathrm{D}$, dissolved organic carbon; other than tritium; MB, microbiological; AC, other anthropogenic organic compounds; ps, public-supply wells; mon, monitoring wells; dom, domestic wells: irr, irrigation wells;

\begin{tabular}{|c|c|c|c|}
\hline $\begin{array}{c}\text { Map } \\
\text { number }\end{array}$ & Study component & Study location & Study purpose \\
\hline 1 & Major-aquifer study & Coastal Basin of the Santa Ana Basin, California & $\begin{array}{l}\text { Broadly characterize water quality in the basin-fill aquifer used for } \\
\text { water supply. }\end{array}$ \\
\hline 2 & Land-use study & Coastal Basin of the Santa Ana Basin, California & Characterize the quality of recently recharged water in an urban setting. \\
\hline 3 & IFlow-path study & Coastal Basin of the Santa Ana Basin, California & $\begin{array}{l}\text { Characterize the spatial and vertical variations in water quality along a } \\
\text { groundwater flow path. }\end{array}$ \\
\hline 4 & Major-aquifer study & Inland Basin of the Santa Ana Basin, California & $\begin{array}{l}\text { Broadly characterize water quality in the basin-fill aquifer used for } \\
\text { water supply. }\end{array}$ \\
\hline 5 & शFlow-path study & $\begin{array}{l}\text { Bunker Hill subbasin, Inland Basin of the Santa Ana } \\
\text { Basin, California }\end{array}$ & $\begin{array}{l}\text { Characterize the spatial and vertical variations in water quality along a } \\
\text { groundwater flow path. }\end{array}$ \\
\hline 6 & Major-aquifer study & San Jacinto Basin of the Santa Ana Basin, California & $\begin{array}{l}\text { Broadly characterize water quality in the basin-fill aquifer used for } \\
\text { water supply. }\end{array}$ \\
\hline 7 & Major-aquifer study & Inland Basins in Northern Coast Ranges area, California & $\begin{array}{l}\text { Broadly characterize water quality in the basin-fill aquifer used for } \\
\text { water supply. }\end{array}$ \\
\hline 8 & Major-aquifer study & $\begin{array}{l}\text { Coastal Basins in Northern Coast Ranges area, } \\
\text { California }\end{array}$ & $\begin{array}{l}\text { Broadly characterize water quality in the basin-fill aquifer used for } \\
\text { water supply. }\end{array}$ \\
\hline 9 & Major-aquifer study & $\begin{array}{l}\text { Southeastern Sacramento Valley of Central Valley, } \\
\text { California }\end{array}$ & $\begin{array}{l}\text { Broadly characterize water quality in the basin-fill aquifer used for } \\
\text { water supply. }\end{array}$ \\
\hline 10 & Land-use study & Sacramento Valley of Central Valley, California & $\begin{array}{l}\text { Characterize the quality of recently recharged water in a rice } \\
\text { agricultural setting. }\end{array}$ \\
\hline 11 & Land-use study & $\begin{array}{l}\text { Southeastern Sacramento Valley of Central } \\
\text { Valley, California }\end{array}$ & Characterize the quality of recently recharged water in an urban setting. \\
\hline 12 & Major-aquifer study & $\begin{array}{l}\text { Eastern alluvial fans in San Joaquin Valley of Central } \\
\text { Valley, California }\end{array}$ & $\begin{array}{l}\text { Broadly characterize water quality in the basin-fill aquifer used for } \\
\text { water supply. }\end{array}$ \\
\hline 13 & Land-use study & $\begin{array}{l}\text { Eastern alluvial fans in San Joaquin Valley of Central } \\
\text { Valley, California }\end{array}$ & $\begin{array}{l}\text { Characterize the quality of recently recharged water in a vineyard } \\
\text { agricultural setting. }\end{array}$ \\
\hline 14 & Land-use study & $\begin{array}{l}\text { Eastern alluvial fans in San Joaquin Valley of Central } \\
\text { Valley, California }\end{array}$ & $\begin{array}{l}\text { Characterize the quality of recently recharged water in an almond } \\
\text { orchard agricultural setting. }\end{array}$ \\
\hline 15 & Land-use study & $\begin{array}{l}\text { Eastern alluvial fans in San Joaquin Valley of Central } \\
\text { Valley, California }\end{array}$ & $\begin{array}{l}\text { Characterize the quality of recently recharged water in corn, alfalfa, and } \\
\text { vegetable row crop agricultural settings. }\end{array}$ \\
\hline 16 & Large-scale TANC study & $\begin{array}{l}\text { Modesto area, eastern alluvial fans in San Joaquin } \\
\text { Valley of Central Valley, California }\end{array}$ & $\begin{array}{l}\text { Broadly characterize water quality in the basin-fill aquifer used for } \\
\text { public supply. }\end{array}$ \\
\hline 17 & $\begin{array}{l}\text { \Local-scale TANC } \\
\text { study }\end{array}$ & $\begin{array}{l}\text { Modesto area, eastern alluvial fans in San Joaquin } \\
\text { Valley of Central Valley, California }\end{array}$ & $\begin{array}{l}\text { Examine factors resulting in detection of natural and anthropogenic } \\
\text { contaminants in a public-supply well. }\end{array}$ \\
\hline 18 & $\begin{array}{l}\text { शLocal-scale agricultural } \\
\text { chemicals study }\end{array}$ & $\begin{array}{l}\text { Near Merced River, eastern alluvial fans in } \\
\text { San Joaquin Valley of Central Valley, California }\end{array}$ & $\begin{array}{l}\text { Characterize the source, transport, and fate of agricultural chemicals } \\
\text { along direction of groundwater flow toward the Merced River. }\end{array}$ \\
\hline 19 & IFlow-path study & $\begin{array}{l}\text { Vineyard land-use area near Fresno, eastern alluvial fans } \\
\text { in San Joaquin Valley of Central Valley, California }\end{array}$ & $\begin{array}{l}\text { Characterize chemical and physical processes along groundwater } \\
\text { flow paths. }\end{array}$ \\
\hline 20 & Land-use study & Truckee Meadows, Nevada & Characterize the quality of recently recharged water in an urban setting. \\
\hline 21 & Major-aquifer study & $\begin{array}{l}\text { Eagle Valley, Truckee Meadows, and Spanish } \\
\text { Springs Valley, Nevada }\end{array}$ & $\begin{array}{l}\text { Broadly characterize water quality in the basin-fill aquifer used for } \\
\text { water supply. }\end{array}$ \\
\hline 22 & Land-use study & Eagle Valley, Nevada & Characterize the quality of recently recharged water in an urban setting. \\
\hline 23 & Large-scale TANC study & Eagle Valley and Spanish Springs Valley, Nevada & $\begin{array}{l}\text { Broadly characterize water quality in the basin-fill aquifer used for } \\
\text { public supply. }\end{array}$ \\
\hline 24 & Major-aquifer study & Carson Valley, Nevada & $\begin{array}{l}\text { Broadly characterize water quality in the basin-fill aquifer used for } \\
\text { water supply. }\end{array}$ \\
\hline 25 & Land-use study & Carson Valley, Nevada & $\begin{array}{l}\text { Characterize the quality of recently recharged water in an agricultural } \\
\text { setting. }\end{array}$ \\
\hline
\end{tabular}


TE, trace elements; P, pesticide compounds; V, volatile organic compounds; R, radon; RA, radium; T, tritium; SI, stable isotopes of oxygen and hydrogen; A, age tracers TANC, Contaminant-transport (Transport of Anthopogenic and Natural Contaminants) study; --, no data]

\begin{tabular}{|c|c|c|c|c|}
\hline Water-quality parameters & Year sampled & $\begin{array}{l}\text { Number } \\
\text { of wells } \\
\text { sampled }\end{array}$ & Well types & Link to report if available online or reference to report \\
\hline $\begin{array}{l}\mathrm{F}, \mathrm{M}, \mathrm{N}, \mathrm{D}, \mathrm{TE}, \mathrm{P}, \mathrm{V},{ }^{*} \mathrm{R}, * \mathrm{~T}, * \mathrm{SI}, \\
\quad \nmid \mathrm{RA}, \dagger \mathrm{MB}\end{array}$ & $\begin{array}{l}1999 \\
2009\end{array}$ & $\begin{array}{l}20 \\
20\end{array}$ & Mostly ps & http://pubs.usgs.gov/wri/wri02-4243/text.html \\
\hline $\mathrm{F}, \mathrm{M}, \mathrm{N}, \mathrm{D}, \mathrm{TE}, \mathrm{P}, \mathrm{V}, \mathrm{R}, \mathrm{T}, \mathrm{SI}$ & 2000 & 26 & mon & http://pubs.usgs.gov/wri/wri02-4243/text.html \\
\hline $\mathrm{F}, \mathrm{M}, \mathrm{N}, \mathrm{D}, \mathrm{TE}, \mathrm{P}, \mathrm{V}, \mathrm{R}, \mathrm{T}, \mathrm{SI}$ & 2000 & 23 & mon & http://pubs.usgs.gov/wri/wrir034059/ \\
\hline $\mathrm{F}, \mathrm{M}, \mathrm{N}, \mathrm{D}, \mathrm{TE}, \mathrm{P}, \mathrm{V}, \mathrm{R}, \mathrm{T}, \mathrm{SI}$ & 2000 & 29 & ps & http://pubs.usgs.gov/wri/wri02-4243/text.html \\
\hline F, M, N, D, TE, P, V, R, T, SI & 2000 & 21 & 20 mon, 1 ps & http://pubs.usgs.gov/wri/wrir034059/ \\
\hline $\mathrm{F}, \mathrm{M}, \mathrm{N}, \mathrm{D}, \mathrm{TE}, \mathrm{P}, \mathrm{V}, \mathrm{R}, \mathrm{T}, \mathrm{SI}$ & 2001 & 23 & Mostly ps & http://pubs.usgs.gov/wri/wri02-4243/text.html \\
\hline $\begin{array}{l}\text { F, M, N, D, TE, P, V, R, T, SI, A, } \\
\quad \text { MB, AC }\end{array}$ & 2009 & 28 & ps, dom, irr & $\begin{array}{l}\text { http://ca.water.usgs.gov/projects/gama/includes/ } \\
\text { GAMA_publications.html }\end{array}$ \\
\hline $\begin{array}{l}\text { F, M, N, D, TE, P, V, R, T, SI, A, } \\
\quad \text { MB, AC }\end{array}$ & 2009 & 30 & Mostly ps, dom & $\begin{array}{l}\text { http://ca.water.usgs.gov/projects/gama/includes/ } \\
\text { GAMA_publications.html }\end{array}$ \\
\hline $\begin{array}{l}\mathrm{F}, \mathrm{M}, \mathrm{N}, \mathrm{D}, \mathrm{TE}, \mathrm{P}, \mathrm{V}, * \mathrm{R}, \mathrm{T}, * \mathrm{SI} \\
\quad \mathrm{A}, \dagger \mathrm{MB}\end{array}$ & $\begin{array}{l}1996 \\
2008\end{array}$ & $\begin{array}{l}31 \\
25\end{array}$ & Mostly dom & http://pubs.usgs.gov/wri/wri014125/ \\
\hline $\mathrm{F}, \mathrm{M}, \mathrm{N}, \mathrm{D}, \mathrm{TE}, \mathrm{P}, \dagger \mathrm{V}, \dagger \mathrm{T}$ & $\begin{array}{l}1997 \\
2006\end{array}$ & $\begin{array}{l}28 \\
23\end{array}$ & mon & http://ca.water.usgs.gov/archive/reports/wrir014000/ \\
\hline $\mathrm{F}, \mathrm{M}, \mathrm{N}, \mathrm{D}, \mathrm{TE}, \mathrm{P}, \mathrm{V}, * \mathrm{R}, \mathrm{A}$ & $\begin{array}{c}1998 \\
2005-06\end{array}$ & $\begin{array}{l}19 \\
25\end{array}$ & mon & http://pubs.usgs.gov/sir/2005/5148/ \\
\hline $\mathrm{F}, \mathrm{M}, \mathrm{N}, \mathrm{D}, \mathrm{TE}, \mathrm{P}, \mathrm{V}, \mathrm{R}$ & $\begin{array}{l}1995 \\
2002\end{array}$ & $\begin{array}{l}30 \\
30\end{array}$ & dom & http://ca.water.usgs.gov/sanj/pub/usgs/wrir98-4040a/wrir98-4040a.html \\
\hline $\mathrm{F}, \mathrm{M}, \mathrm{N}, \mathrm{D}, \mathrm{TE}, \mathrm{P}, \mathrm{V}, \mathrm{R}$ & $\begin{array}{c}1993-94 \\
2001\end{array}$ & $\begin{array}{l}30 \\
30\end{array}$ & mon, dom & http://ca.water.usgs.gov/sanj/pub/usgs/wrir97-4284/wrir97-4284.html \\
\hline $\mathrm{F}, \mathrm{M}, \mathrm{N}, \mathrm{D}, \mathrm{TE}, \mathrm{P}, \mathrm{V}, \mathrm{R}$ & $\begin{array}{l}1994 \\
2001\end{array}$ & $\begin{array}{l}30 \\
30\end{array}$ & mon, dom & http://ca.water.usgs.gov/sanj/pub/usgs/wrir97-4284/wrir97-4284.html \\
\hline $\mathrm{F}, \mathrm{M}, \mathrm{N}, \mathrm{D}, \mathrm{TE}, \mathrm{P}, \mathrm{V}, \mathrm{R}$ & $\begin{array}{l}1995 \\
2002\end{array}$ & $\begin{array}{l}30 \\
30\end{array}$ & mon, dom & http://ca.water.usgs.gov/sanj/pub/usgs/wrir97-4284/wrir97-4284.html \\
\hline $\mathrm{F}, \mathrm{M}, \mathrm{N}, \mathrm{D}, \mathrm{TE}, \mathrm{P}, \mathrm{V}, \mathrm{AC}$ & 2002 & 15 & ps & -- \\
\hline F, M, N, D, TE, V, R, RA, T, SI, A & $2003-05$ & 24 & $23 \mathrm{mon}, 1 \mathrm{ps}$ & $\begin{array}{l}\text { http://pubs.usgs.gov/sir/2008/5035/ } \\
\text { and http://pubs.usgs.gov/sir/2008/5156/ }\end{array}$ \\
\hline $\mathrm{F}, \mathrm{M}, \mathrm{N}, \mathrm{D}, \mathrm{P}, \mathrm{T}, \mathrm{A}$ & 2004 & 12 & mon & http://pubs.usgs.gov/sir/2007/5009/ \\
\hline $\mathrm{F}, \mathrm{M}, \mathrm{N}, \mathrm{D}, \mathrm{TE}, \mathrm{P}, \mathrm{V}, \mathrm{R}, \mathrm{A}, \mathrm{AC}$ & $\begin{array}{l}1994-95 \\
2003-04\end{array}$ & 20 & mon & http://ca.water.usgs.gov/sanj/pub/usgs/wrir99-4059/wrir99-4059.html \\
\hline $\mathrm{F}, \mathrm{M}, \mathrm{N}, \mathrm{D}, \mathrm{TE}, \mathrm{P}, \mathrm{V},{ }^{\mathrm{R}}$ & $\begin{array}{l}1994 \\
2002\end{array}$ & $\begin{array}{l}28 \\
12\end{array}$ & mon & http://pubs.er.usgs.gov/publication/ofr 97222 \\
\hline $\mathrm{F}, \mathrm{M}, \mathrm{N}, \mathrm{D}, \mathrm{TE}, \mathrm{P}, \mathrm{V}, \mathrm{R}, \dagger \mathrm{T}, \dagger \mathrm{MB}$ & $\begin{array}{l}1995 \\
2003\end{array}$ & $\begin{array}{r}\S 18 \\
30\end{array}$ & Mostly ps & http://pubs.er.usgs.gov/publication/ofr 97222 \\
\hline $\mathrm{F}, \mathrm{M}, \mathrm{N}, \mathrm{D}, \mathrm{TE}, \mathrm{P}, \mathrm{V}$ & 2002 & 19 & mon & -- \\
\hline $\mathrm{F}, \mathrm{M}, \mathrm{N}, \mathrm{D}, \mathrm{TE}, \mathrm{P}, \mathrm{V}, \mathrm{MB}, \mathrm{AC}$ & 2002 & 15 & ps & http://pubs.usgs.gov/sir/2006/5210/ \\
\hline F, M, N, D, TE, P, V, R & 1995 & 18 & Mostly dom, ps & http://pubs.er.usgs.gov/publication/wri974259 \\
\hline F, M, N, D, TE, P, V, R & 1994 & 20 & mon & http://pubs.er.usgs.gov/publication/wri974259 \\
\hline
\end{tabular}




\section{Table A1-1. Study components of the Southwest Principal Aquifers water-quality assessment.—Continued}

[F, field parameters including water temperature, specific conductance, $\mathrm{pH}$, alkalinity, turbidity, and dissolved oxygen; M, major ions; $\mathrm{N}$, nutrients; $\mathrm{D}$, dissolved organic carbon; other than tritium; MB, microbiological; AC, other anthropogenic organic compounds; ps, public-supply wells; mon, monitoring wells; dom, domestic wells: irr, irrigation wells;

\begin{tabular}{|c|c|c|c|}
\hline $\begin{array}{c}\text { Map } \\
\text { number }\end{array}$ & Study component & Study location & Study purpose \\
\hline 26 & Land-use study & Carson Desert, Nevada & $\begin{array}{l}\text { Characterize the quality of recently recharged water in an agricultural } \\
\text { setting. }\end{array}$ \\
\hline 27 & Major-aquifer study & Las Vegas Valley, Nevada & $\begin{array}{l}\text { Broadly characterize water quality in the basin-fill aquifer used for } \\
\text { water supply. }\end{array}$ \\
\hline 28 & Land-use study & Las Vegas Valley, Nevada & Characterize the quality of recently recharged water in an urban setting. \\
\hline 29 & 『Major-aquifer study & $\begin{array}{l}\text { Basin and Range carbonate-rock aquifers, Utah } \\
\text { and Nevada }\end{array}$ & Broadly characterize water quality in the carbonate-rock aquifers. \\
\hline 30 & Major-aquifer study & West Salt River Valley, Arizona & $\begin{array}{l}\text { Broadly characterize water quality in the basin-fill aquifer used for } \\
\text { water supply. }\end{array}$ \\
\hline 31 & Land-use study & Western part of West Salt River Valley, Arizona & $\begin{array}{l}\text { Characterize the quality of recently recharged water in an agricultural } \\
\text { setting. }\end{array}$ \\
\hline 32 & Major-aquifer study & Upper Santa Cruz Basin, Arizona & $\begin{array}{l}\text { Broadly characterize water quality in the basin-fill aquifer used for } \\
\text { water supply. }\end{array}$ \\
\hline 33 & Major-aquifer study & Sierra Vista subbasin, Arizona & $\begin{array}{l}\text { Broadly characterize water quality in the basin-fill aquifer used for } \\
\text { water supply. }\end{array}$ \\
\hline 34 & Major-aquifer study & Great Salt Lake drainage basin, Utah and Idaho & $\begin{array}{l}\text { Broadly characterize water quality in unconfined part of basin-fill aqui- } \\
\text { fers near the mountain front used for water supply. }\end{array}$ \\
\hline 35 & Major-aquifer study & Great Salt Lake drainage basin, Utah and Idaho & $\begin{array}{l}\text { Broadly characterize water quality in confined part of basin-fill aquifers } \\
\text { used for water supply where the vertical hydraulic gradient is down- } \\
\text { ward. }\end{array}$ \\
\hline 36 & 『Major-aquifer study & Salt Lake Valley, Utah & $\begin{array}{l}\text { Broadly characterize water quality in the basin-fill aquifer used for } \\
\text { water supply. }\end{array}$ \\
\hline 37 & Land-use study & Salt Lake Valley, Utah & Characterize the quality of recently recharged water in an urban setting. \\
\hline 38 & Large-scale TANC study & Salt Lake Valley, Utah & $\begin{array}{l}\text { Broadly characterize water quality in the basin-fill aquifer used for } \\
\text { public supply. }\end{array}$ \\
\hline 39 & Land-use study & Alamosa Basin, San Luis Valley, Colorado & $\begin{array}{l}\text { Characterize the quality of recently recharged water in an agricultural } \\
\text { setting irrigated with groundwater by overhead, center pivot sprin- } \\
\text { klers. }\end{array}$ \\
\hline 40 & Major-aquifer study & $\begin{array}{l}\text { Rio Grande floodplain of the Middle Rio Grande, } \\
\text { Socorro, San Marcial, Palomas, and Mesilla Basins, } \\
\text { New Mexico }\end{array}$ & $\begin{array}{l}\text { Broadly characterize water quality in the basin-fill aquifer used for } \\
\text { water supply. }\end{array}$ \\
\hline 41 & Land-use study & $\begin{array}{l}\text { Rio Grande floodplain near Albuquerque, Middle Rio } \\
\text { Grande Basin, New Mexico }\end{array}$ & Characterize the quality of recently recharged water in an urban setting. \\
\hline 42 & Land-use study & $\begin{array}{l}\text { Rincon-Hatch area of the Rio Grande floodplain, } \\
\text { Palomas Basin, New Mexico }\end{array}$ & $\begin{array}{l}\text { Characterize the quality of recently recharged water in an agricultural } \\
\text { setting flood irrigated with surface water. }\end{array}$ \\
\hline 43 & Large-scale TANC study & Northern Middle Rio Grande Basin, New Mexico & $\begin{array}{l}\text { Broadly characterize water quality in basin-fill aquifer used for public } \\
\text { supply. }\end{array}$ \\
\hline 44 & $\begin{array}{l}\text { ๆLocal-scale TANC } \\
\text { study }\end{array}$ & $\begin{array}{l}\text { Albuquerque area, Middle Rio Grande Basin, } \\
\text { New Mexico }\end{array}$ & $\begin{array}{l}\text { Examine factors resulting in detection of natural and anthropogenic } \\
\text { contaminants in a public-supply well. }\end{array}$ \\
\hline
\end{tabular}

*Analyzed in samples collected during 1991-2001 only.

$\dagger$ Analyzed in samples collected during 2002-09 only.

TSamples from study not in dataset described in appendix 2.

$\S$ Wells sampled in Truckee Meadows only. 
TE, trace elements; P, pesticide compounds; V, volatile organic compounds; R, radon; RA, radium; T, tritium; SI, stable isotopes of oxygen and hydrogen; A, age tracers TANC, Contaminant-transport (Transport of Anthopogenic and Natural Contaminants) study; --, no data]

\begin{tabular}{|c|c|c|c|c|}
\hline Water-quality parameters & Year sampled & $\begin{array}{l}\text { Number } \\
\text { of wells } \\
\text { sampled }\end{array}$ & Well types & Link to report if available online or reference to report \\
\hline $\mathrm{F}, \mathrm{M}, \mathrm{N}, \mathrm{D}, \mathrm{TE}, \mathrm{P}, \mathrm{V}, \mathrm{R}$ & 1994 & 10 & mon & http://pubs.er.usgs.gov/publication/wri974259 \\
\hline $\mathrm{F}, \mathrm{M}, \mathrm{N}, \mathrm{D}, \mathrm{TE}, \mathrm{P}, \mathrm{V}, \mathrm{R}$ & 1995 & 22 & Mostly ps, dom & http://pubs.er.usgs.gov/publication/wri974259 \\
\hline $\mathrm{F}, \mathrm{M}, \mathrm{N}, \mathrm{D}, \mathrm{TE}, \mathrm{P}, \mathrm{V}, \mathrm{R}$ & 1993 & 32 & mon & http://pubs.er.usgs.gov/publication/ofr 96552 \\
\hline F, M, N, D, TE, P, V, R, SI, T, MB & 2003 & $\begin{array}{l}18 \text { wells, } \\
12 \text { springs }\end{array}$ & Mostly mon, ps & http://pubs.usgs.gov/sir/2005/5232 \\
\hline $\begin{array}{l}\mathrm{F}, \mathrm{M}, \mathrm{N}, \mathrm{D}, \mathrm{TE}, \mathrm{P}, \mathrm{V}, * \mathrm{R}, * \mathrm{~T},{ }^{*} \mathrm{SI} \\
\quad \dagger \mathrm{A}, \dagger \mathrm{MB}, \dagger \mathrm{RA}\end{array}$ & $\begin{array}{c}1996-97 \\
2008\end{array}$ & $\begin{array}{l}35 \\
35\end{array}$ & $\begin{array}{l}\text { Mostly dom, } \\
\text { ps, irr }\end{array}$ & http://az.water.usgs.gov/pubs/WRIR01-4126intro.html \\
\hline $\mathrm{F}, \mathrm{M}, \mathrm{N}, \mathrm{D}, \mathrm{TE}, \mathrm{P}, \mathrm{V}, \mathrm{R}, \mathrm{T}, \mathrm{SI}$ & $\begin{array}{l}1997 \\
1998\end{array}$ & $\begin{array}{l}9 \\
9\end{array}$ & mon & http://az.water.usgs.gov/pubs/WRIR01-4126intro.html \\
\hline $\mathrm{F}, \mathrm{M}, \mathrm{N}, \mathrm{D}, \mathrm{TE}, \mathrm{P}, \mathrm{V}, \mathrm{R}, \mathrm{T}, \mathrm{SI}$ & 1998 & 29 & Mostly dom & http://az.water.usgs.gov/pubs/WRIR00-4117intro.html \\
\hline $\mathrm{F}, \mathrm{M}, \mathrm{N}, \mathrm{D}, \mathrm{TE}, \mathrm{P}, \mathrm{V}, \mathrm{R}, \mathrm{T}, \mathrm{SI}$ & 1996 & 19 & Mostly dom & http://pubs.er.usgs.gov/publication/wri994056 \\
\hline $\mathrm{F}, \mathrm{M}, \mathrm{N}, \mathrm{D}, \mathrm{TE}, \mathrm{P}, \mathrm{V}, \mathrm{R}, \mathrm{T}, \mathrm{SI}$ & 1998 & 26 & $\begin{array}{l}\text { Mostly dom, } \\
\text { ps, irr }\end{array}$ & -- \\
\hline F, M, N, D, TE, P, V, R, T, SI & 1998 & 29 & $\begin{array}{l}\text { Mostly dom, } \\
\text { ps, irr }\end{array}$ & -- \\
\hline $\mathrm{F}, \mathrm{M}, \mathrm{N}, \mathrm{D}, \mathrm{TE}, \mathrm{P}, \mathrm{V}, \mathrm{T}, \mathrm{A}, \mathrm{MB}, \mathrm{RA}$ & 2008 & 34 & Mostly dom, ps & -- \\
\hline F, M, N, D, TE, P, V, R, T, SI, A & 1999 & 30 & mon & http://pubs.water.usgs.gov/wri034028 http:// \\
\hline F, M, N, D, TE, P, V, R, T, SI, A & 2001 & 31 & ps & pubs.water.usgs.gov/wri034325 http:// \\
\hline $\mathrm{F}, \mathrm{M}, \mathrm{N}, \mathrm{D}, \mathrm{TE}, \mathrm{P}, * \mathrm{R}, \dagger \mathrm{T}, \dagger \mathrm{A}, \dagger \mathrm{SI}$ & $\begin{array}{l}1993 \\
2007\end{array}$ & $\begin{array}{l}35 \\
33\end{array}$ & mon & pubs.er.usgs.gov/publication/wri964144 \\
\hline $\mathrm{F}, \mathrm{M}, \mathrm{N}, \mathrm{D}, \mathrm{TE}, \mathrm{P}, \mathrm{V}, \mathrm{R}$ & 1995 & 30 & Mostly dom & http://pubs.er.usgs.gov/publication/wri964249 \\
\hline $\begin{array}{l}\mathrm{F}, \mathrm{M}, \mathrm{N}, \mathrm{D}, \mathrm{TE}, \mathrm{P}, \mathrm{V}, * \mathrm{R}, \dagger \mathrm{SI}, \dagger \mathrm{T}, \\
\quad \dagger \mathrm{A}\end{array}$ & $\begin{array}{l}1993 \\
2006\end{array}$ & $\begin{array}{l}24 \\
31\end{array}$ & mon & http://pubs.er.usgs.gov/publication/wri 974067 \\
\hline $\mathrm{F}, \mathrm{M}, \mathrm{N}, \mathrm{D}, \mathrm{TE}, \mathrm{P}, * \mathrm{R}, \uparrow \mathrm{A}, \dagger \mathrm{SI}$ & $\begin{array}{l}1994 \\
2006\end{array}$ & $\begin{array}{l}30 \\
30\end{array}$ & mon & http://pubs.usgs.gov/wri/wri02-4188/pdf/wrir02-4188.pdf \\
\hline $\mathrm{F}, \mathrm{M}, \mathrm{N}, \mathrm{D}, \mathrm{TE}, \mathrm{P}, \mathrm{V}, \mathrm{MB}, \uparrow \mathrm{AC}$ & 2005 & 39 & ps & -- \\
\hline F, M, N, D, TE, V, R, RA, T, SI, A & 2007-09 & 25 & 22 mon, 3 ps & -- \\
\hline
\end{tabular}




\section{Appendix 2. Water-Quality Properties and Constituents Measured, a Summary of Data, and Complete Data Archive for 1993-2009}

Water-quality properties and constituents measured and a summary of data for 1993-2009, including laboratory reporting levels and human-health benchmarks for drinking water, are presented only online. A data summary is available for download at http://pubs.usgs.gov/circ/1358/and includes the tables and figure listed below. The complete data archive is included with the report that summarizes groundwater quality for many of the Nation's Principal Aquifers(84) and is available at http://pubs.usgs.gov/circ/1360/.

Figure A2-1. A concentration of a constituent exceeded its human-health benchmark in a total of 257 cases in samples collected by the NAWQA Program from public-supply and domestic wells in the Southwest Principal Aquifers study area. Most of the constituents that occurred at a concentration that exceeded a benchmark were those with a geologic source, but some were for nitrate, manmade chemicals, or a combination of constituent types.

Table A2-1. Water-quality properties and constituents analyzed in samples collected during 1993-2009 from the Southwest Principal Aquifers, including laboratory reporting levels and human-health benchmarks for drinking water.

Table A2-2. Constituents with geologic sources that exceeded a human-health benchmark or Secondary Maximum Contaminant Level in water sampled from at least one drinking-water well completed in Southwest basin-fill aquifers.

Table A2-3. Selected human-related constituents detected in water sampled from wells completed in Southwest basinfill aquifers. 


\section{Appendix 3. Water-Quality Data From Southwest Basin-Fill Aquifers in a National Context}

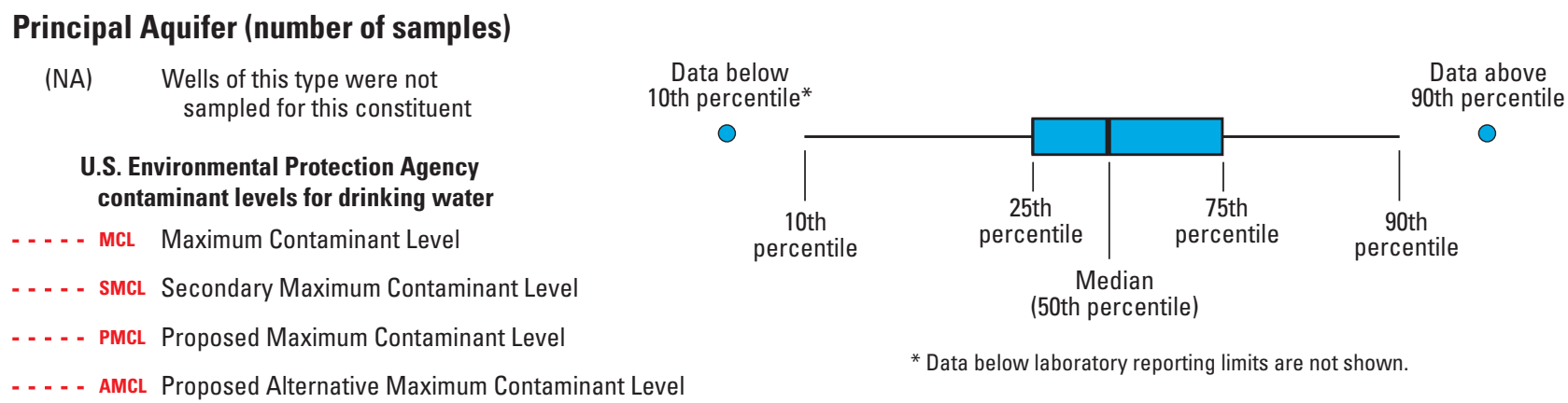

Lithology

Basalt and volcanics**

Crystalline

Carbonate

Sandstone

Semiconsolidated sand and gravel

Glacial unconsolidated sand and gravel

Unconsolidated sand and gravel (nonglacial)

This appendix shows graphical comparisons of chemical concentrations (1991 to 2010) for selected inorganic and organic constituents of potential health or aquatic-life concern in selected Principal Aquifers of the United States. For each constituent, the concentration data are grouped according to two well types: domestic wells and public-supply wells. For each well type, the aquifers also are grouped according to aquifer lithology: basalt and volcanics, ${ }^{* *}$ crystalline, carbonate, sandstone, semiconsolidated sand and gravel, glacial unconsolidated sand and gravel, and unconsolidated sand and gravel (nonglacial).

The number of samples for a constituent varies among Principal Aquifers, and data for a particular compound were not plotted if there were fewer than 10 samples for a Principal Aquifer. Not all Principal Aquifers for which data are available are shown. Note that analytical detection limits vary among the constituents. Boxplots are truncated at common assessment levels and data reported as non-detects or analytical values below common assessment levels are not shown. The data used in this appendix and boxplots for additional constituents are available at http://pubs.usgs.gov/circ/1360/.

** Note: Two of the Principal Aquifers in this group include limited samples from basin-fill aquifers within the extent of the basaltic aquifer. 
Principal Aquifer Snake River Plain basin fill-basalt rock (54) Hawaiian volcanic (NA) New England crystalline (107) Piedmont and Blue Ridge crystalline (99) Castle Hayne (6) Upper Floridan (128) Piedmont and Blue Ridge carbonate (NA) Valley and Ridge carbonate (28) Cambrian-Ordovician (69) Denver Basin (75) Early Mesozoic (24) Valley and Ridge siliciclastic (27) Mississippi embayment (27) Northern Atlantic Coastal Plain (60) Texas coastal uplands (50) Glacial-Central (187) Glacial-West Central (76) Glacial-West (23)

Basin and Range basin fill (129) California Coastal Basin (18) Central Valley (135) Rio Grande (25)

Alluvial-Denver Basin (7) Alluvial-Pleistocene terrace deposits (NA) High Plains (313)

Mississippi River Valley alluvial (5) Surficial (30)

$$
0.1
$$

Concentration, in micrograms per liter

Arsenic in domestic wells
Columbia Plateau basin fill-basalt rock (NA) Glacial-East (68)

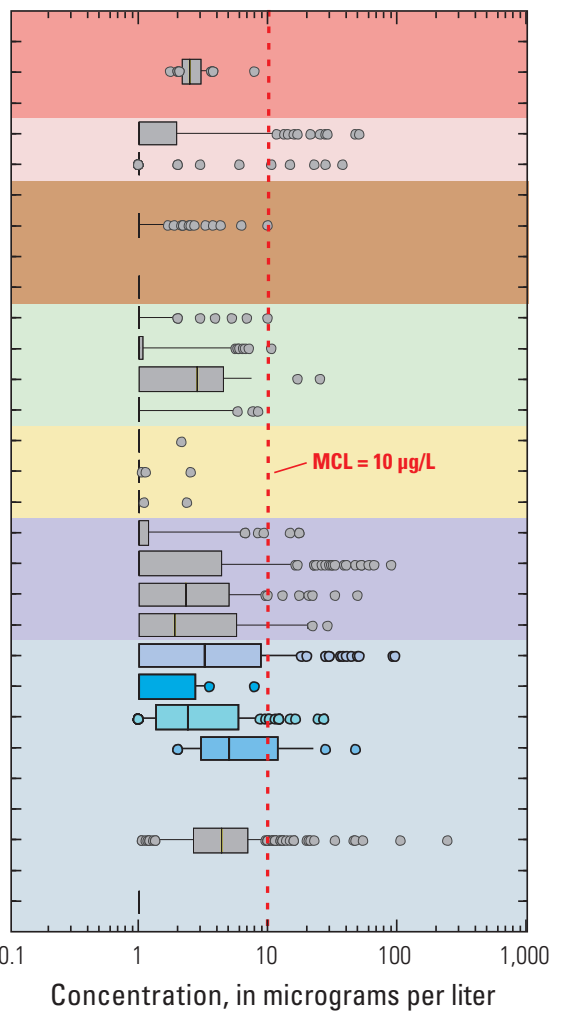

Principal Aquifer

Columbia Plateau basin fill-basalt rock (NA) Snake River Plain basin fill-basalt rock (54) Hawaiian volcanic (NA) New England crystalline (113) Piedmont and Blue Ridge crystalline (152) Castle Hayne (6) Upper Floridan (128) Piedmont and Blue Ridge carbonate (29) Valley and Ridge carbonate (94) Cambrian-Ordovician (69) Denver Basin (75) Early Mesozoic (48) Valley and Ridge siliciclastic (82) Mississippi embayment (27) Northern Atlantic Coastal Plain (60)

Texas coastal uplands (50) Glacial-East (68) Glacial-Central (187) Glacial-West Central (93) Glacial-West (24)

Basin and Range basin fill (129) California Coastal Basin (18) Central Valley (135) Rio Grande (25)

Alluvial-Denver Basin (7) Alluvial-Pleistocene Terrace Deposits (NA) High Plains (313) Mississippi River Valley alluvial (5) Surficial (30)

$$
0.1
$$

\section{Uranium in domestic wells}

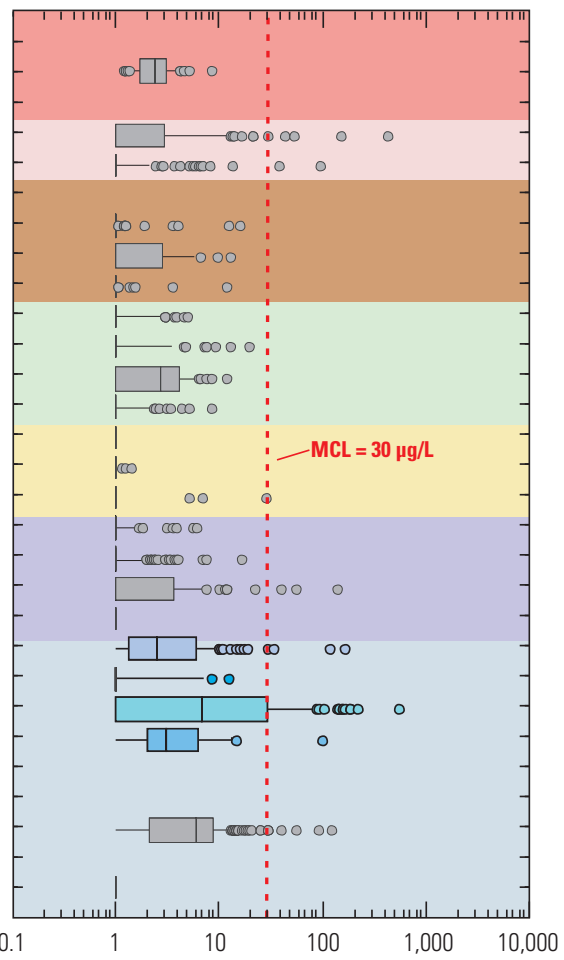

Concentration, in micrograms per liter

\section{Arsenic in public-supply wells}

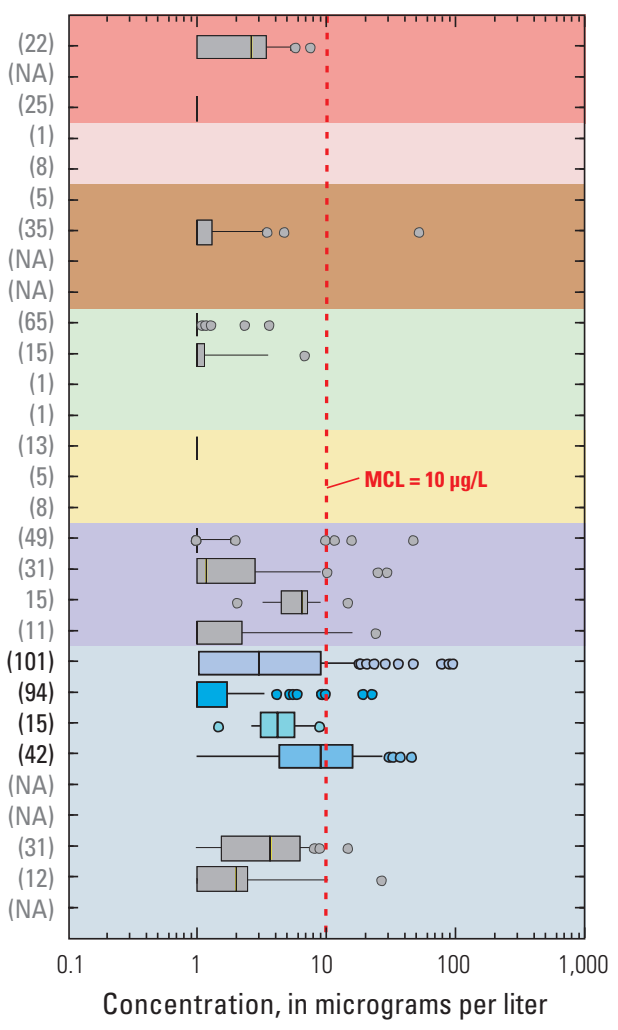

Uranium in public-supply wells

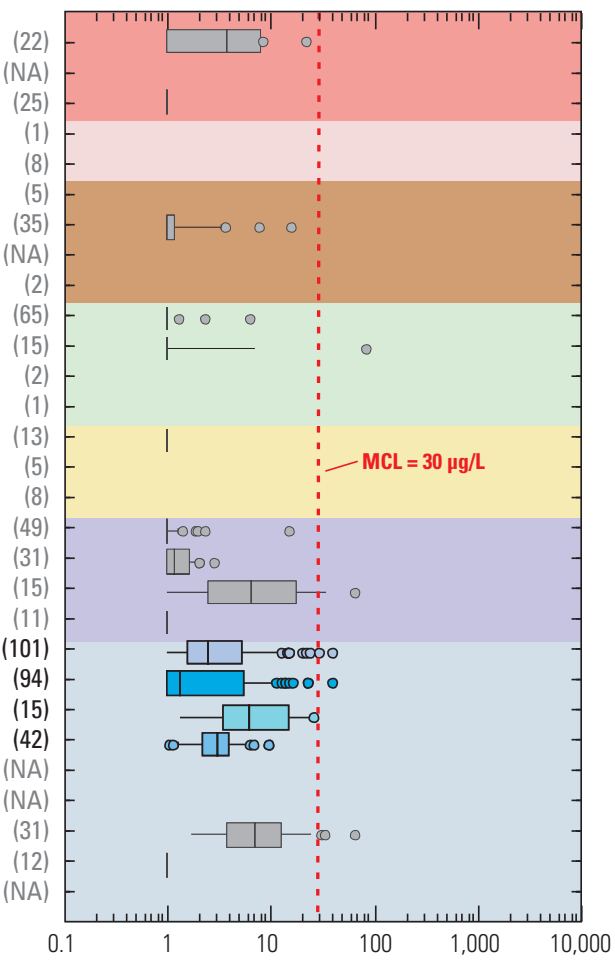

Concentration, in micrograms per liter 


\section{Principal Aquifer Nitrate and nitrite in domestic wells}

Columbia Plateau basin fill-basalt rock (63) Snake River Plain basin fill-basalt rock (151)

Hawaiian volcanic (NA) New England crystalline (113)

Piedmont and Blue Ridge crystalline (151) Castle Hayne (6) Upper Floridan (127)

Piedmont and Blue Ridge carbonate (29) Valley and Ridge carbonate (116)

Cambrian-Ordovician (71) Denver Basin (75) Early Mesozoic (69) Valley and Ridge siliciclastic (81) Mississippi embayment (27) Northern Atlantic Coastal Plain (66) Texas coastal uplands $(50)$ Glacial-East (97) Glacial-Central (210) Glacial-West Central (96 Glacial-West (55) Basin and Range basin fill (123) California Coastal Basin (18) Central Valley (137) Rio Grande (25)

Alluvial-Denver Basin (7) Alluvial-Pleistocene terrace deposits (NA) High Plains (314) Mississippi River Valley alluvial (5) Surficial (30)

Principal Aquifer

Columbia Plateau basin fill-basalt rock (62) Snake River Plain basin fill-basalt rock (103 Hawailan volcanic (NA) New England crystalline (113

Piedmont and Blue Ridge crystalline (152) Castle Hayne (6) Upper Floridan (128) Piedmont and Blue Ridge carbonate (29)

Valley and Ridge carbonate (117) Cambrian-Ordovician (71) Denver Basin (75) Early Mesozoic (68) Valley and Ridge siliciclastic (80)

Mississippi embayment (27) Northern Atlantic Coastal Plain (66)

Texas coastal uplands (50) Glacial-East (98 Glacial-Central (208

Glacial-West Central (115) Glacial-West (54)

Basin and Range basin fill (131) California Coastal Basin (18) Central Valley (138)

Rio Grande (25)

Alluvial-Denver Basin (7) Alluvial-Pleistocene terrace deposits (NA) High Plains (311) Mississippi River Valley alluvial (5) Surficial (30)

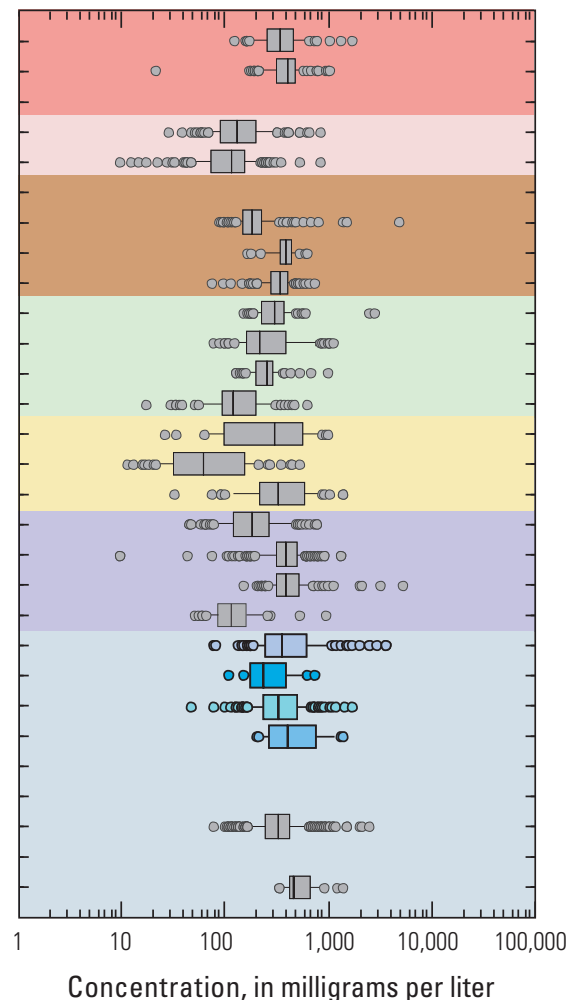

Concentration, in milligrams per liter
Nitrate and nitrite in public-supply wells
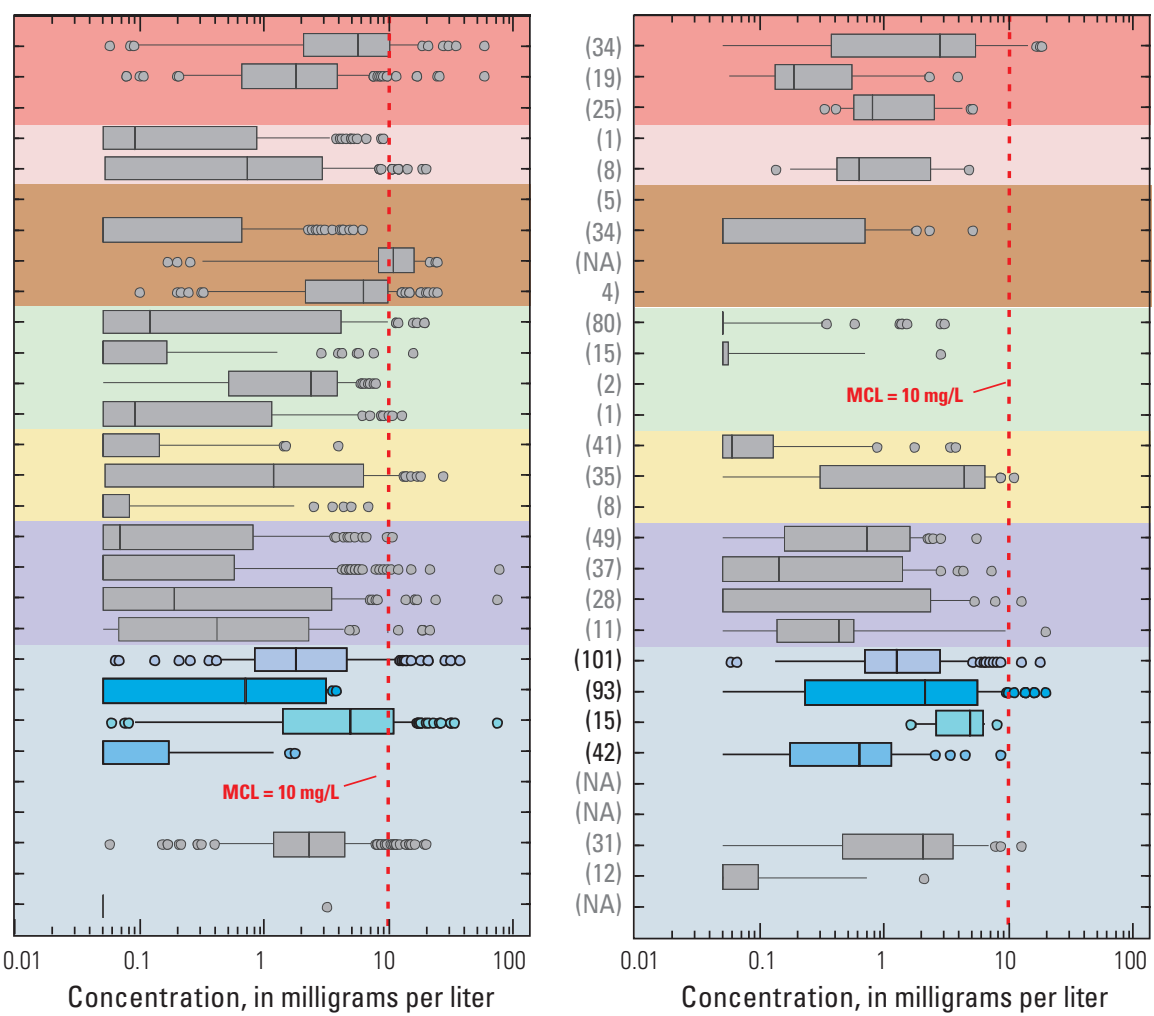

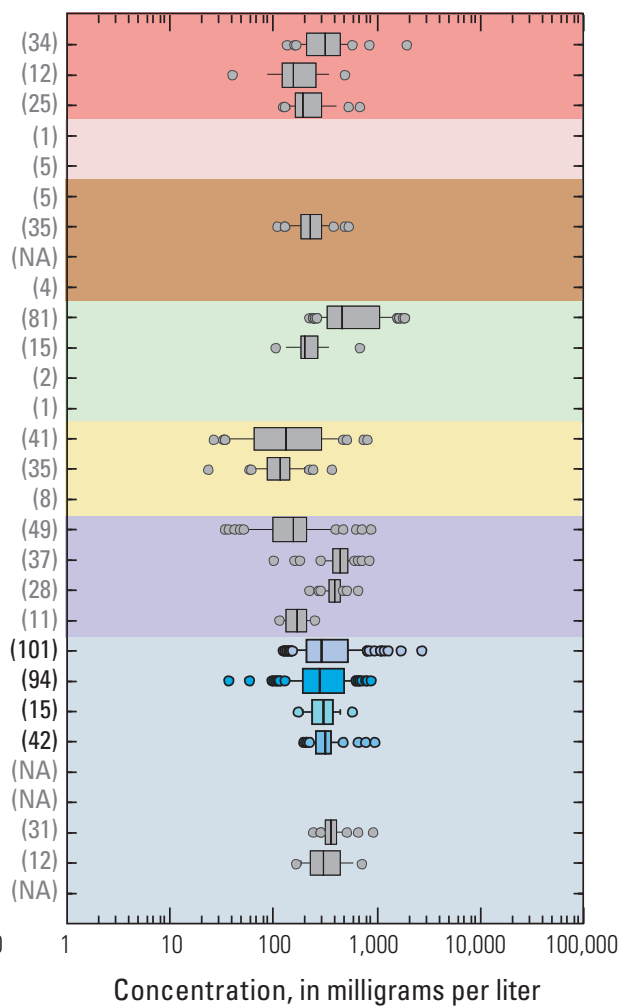



Prepared by the USGS Science Publishing Network

Pembroke, Raleigh, and Menlo Park Publishing Service Centers Edited by Kay P. Naugle, Raleigh

Illustrations by David Jones, Menlo Park and Christine T. Mendelsohn, Pembroke

Layout by Christine T. Mendelsohn

For more information concerning this report, contact: Chief, National Water-Quality Assessment Program

U.S. Geological Survey

413 National Center

12201 Sunrise Valley Drive

Reston, VA 20192

http://water.usgs.gov/nawqa/ 


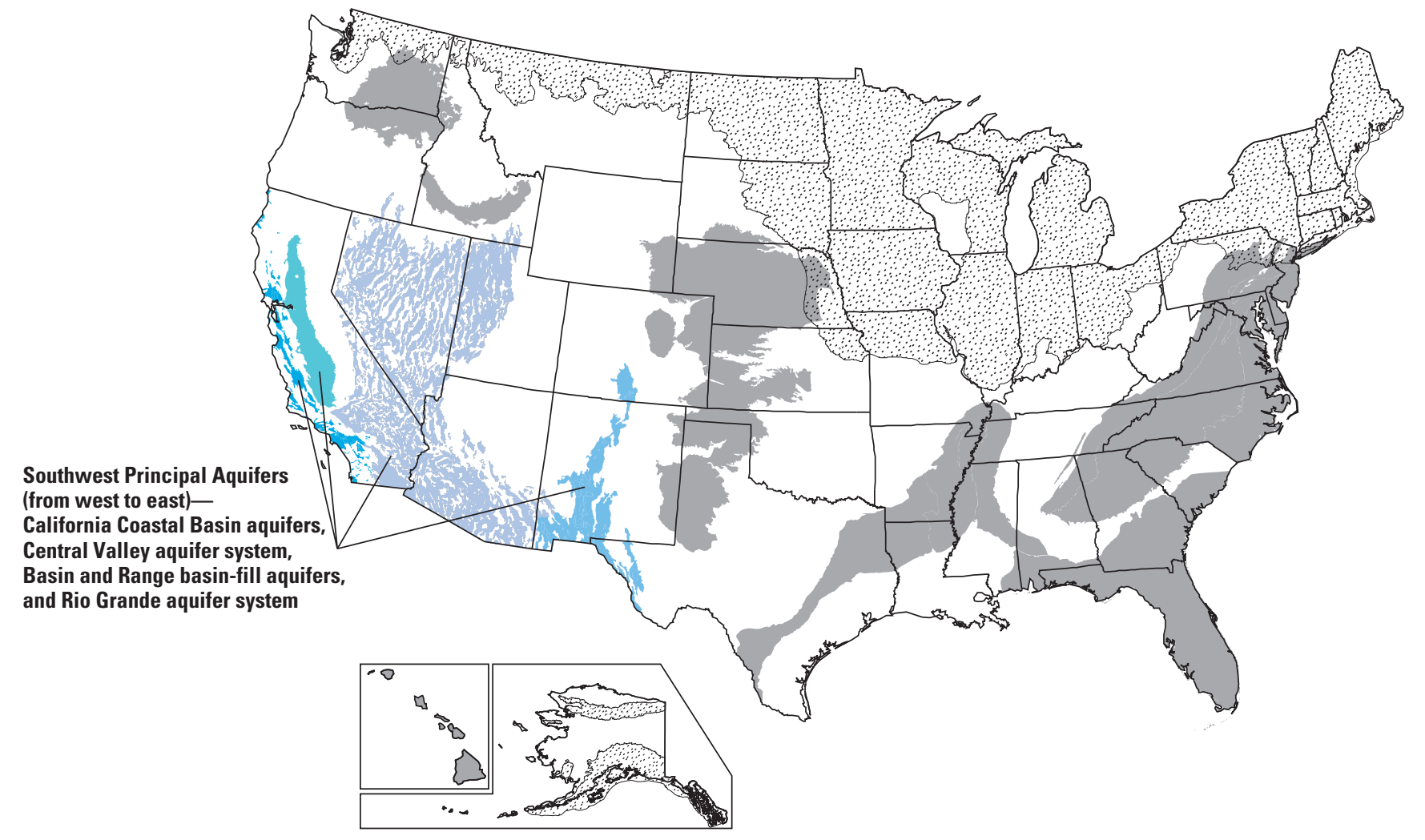

